\title{
$\frac{((x-))}{\text { ypen }}$
}

Autarquia Associada à Universidade de São Paulo

\section{Obtenção de Membranas de Hidrogéis para \\ Tratamento Alternativo da Leishmaniose \\ Tegumentar}

MARIA JOSÉ ALVES DE OLIVEIRA

Tese apresentada como parte dos requisitos para obtenção do grau de Doutora em Ciências na área de Tecnologia Nuclear - Materiais.

Orientadora:

Profa. Dra. Duclerc Fernandes Parra

Coorientador:

Prof. Dr. Valdir Sabbaga Amato

\section{São Paulo}


A meu pai Geraldo in memorim e a minha mãe Maria do Carmo, por terem me ensinado a ter perseverança para alcançar meus objetivos.

A meus irmãos Marcos e Maria da Guia por todo apoio e carinho.

Ás minhas filhas a razão maior da minha vida, meu equilíbrio... 
"Por fim, somos gratos pela curiosidade e engenhosidade dos químicos que nos precederam. Sem seus esforços, nunca teríamos experimentado o entendimento e a fascinação que constituem a alegria da química".

(Os Botões de Napoleão) 
"Eterno, é tudo aquilo que dura uma fração de segundo, mas com tanta intensidade, que se petrifica e nenhuma força jamais o resgata".

(Carlos Drummond de Andrade) 


\section{AGRADECIMENTOS}

Agradeço primeiramente a Deus, por ter iluminado meu caminho e guiado os meus passos, e por assim permanecer comigo na grande jornada que ainda tenho pela frente.

À minha orientadora, Prof. Dra. Duclerc, pela confiança, pelo incentivo, pelo carinho e pela orientação.

Ao meu Coorientador, Prof. Dr. Valdir pela oportunidade de desenvolver os testes "in vivo" disponibilizando o laboratório e biotério.

À equipe do LIM46 - Laboratório de Investigação Médica - do Instituto de Medicina Tropical USP, Dr. Valdir Amato, Dra. Lúcia Braz, Regina Maia Erica Gakiya pelo suporte com os testes "in vivo".

Ao Instituto de Pesquisa Energéticas e Nucleares (IPEN/CNEN-SP) pela oportunidade de desenvolver este trabalho.

À Fundação de Amparo a Pesquisa do Estado de São Paulo (FAPESP), pela bolsa concedida, processo 09/50926-1.

À Empresa Brasileira de Radiações (EMBRARAD/CBE) e ao Centro de Tecnologia das Radiações (CTR), pela irradiação das membranas.

Ao Sr. Eleosmar Gasparin do Centro de Química e Meio Ambiente (CQMA) do IPEN/CNEN-SP pelas análises térmicas.

Ao Sr. Celso Vieira do Centro de Ciência e Tecnologia dos Materiais do IPEN/CNEN-SP, pelas análises de microscopia eletrônica de varredura (MEV). 
Aos Srs. Vinícius e Lucas Farias, pelo treinamento oferecido para fazer as análises de Microscopia Força Atômica (AFM) localizado no laboratório Sicrontron (LNLS) Campinas-SP.

À Dra. Marycel E. B. Cotrim, Centro de Química e Meio Ambiente (CQMA) do IPEN/CNEN-SP, pelas análises de Espectrometria de Absorção Atômica com atomização por forno de grafita.

À Sizue O. Rogero, Centro de Química e Meio Ambiente (CQMA) do IPEN/CNEN-SP, pelo suporte dos testes de citotoxicidade.

Ao Prof. Dr. Ademar B. Lugão por sua colaboração durante 0 desenvolvimento deste trabalho e por todo suporte que precisei durante essa passagem pelo IPEN.

Aos meus amigos do CQMA: Adriana Napoleão, Antonio Brant, Brandão, Estefânia Oliveira, Cláudia Felinto, Danilo Firmino, Débora Salum, Edson Takeshi, Elesomar Gasparin, Beth Cardoso, Geise Ribeiro, Henrique Ferreira, Helber Holland, Heloisa Zen, Harumi Otaguro, Hélio Ferreto, Jacinete dos Santos, João Batista, Jorge Vaz, José Pereira, José Seneda, Lia, Liana Nakamura, Luis Filipe, Luiza Melo, Leonardo Marchini, Mitiko Myamaura, Mara Alcântara, Natalia Naime, Nelson Bueno, Pedro Forter, Pedro Vicente, Patrícia Ponce, Paula Paganini, Rodrigo Shinzato, Ricardo Cavaleiro, Rosário, Sandra Sclagliusi, Izildinha Quiroz, Valderlei, Washington Oliani, pelo carinho e o apoio que recebo desde que cheguei ao IPEN, esses são os amigos que me fizeram sorrir sempre todos os dias.

Aos meus amigos que direta ou indiretamente colaboraram para a realização deste trabalho, em especial: Willian Cuenca, Elisangela Oliveira, Vilmária Aparecida, Kelly Leme, Silvia Boffa, Kalyncca, Ana Thereza, Aldo Malagó, Filipe Ponce e os professores de Química das Faculdades Oswaldo Cruz, pelo carinho e amizade.

Ao Prof. Júlio Carreiro, pelo carinho e pelos desafios. 
À Flávia Motta, pelo carinho, por me ouvir quando eu não estava aguentando seguir, pelos momentos de boas risadas, as frutas, os lanches feitos pelo seu pai, os almoços, as caminhadas, os mistérios do estacionamento do IQ. Não poderia esquecer a melhor parte te fazer correr 5 $\mathrm{km}$ em 5 minutos. Essas e outras histórias vão para a pracinha com direito a bengala, pantufa e aquela companhia especial... rsrsr. 


\title{
OBTENÇÃO DE MEMBRANAS DE HIDROGÉIS PARA TRATAMENTO ALTERNATIVO DA LEISHMANIOSE TEGUMENTAR
}

\author{
Maria José Alves de Oliveira
}

\begin{abstract}
RESUMO
Os hidrogéis foram obtidos a partir de material polimérico reticulado por processo de radiação ionizante de acordo com a técnica de Rosiak. Nos últimos 40 anos o uso dos hidrogéis têm sido investigado para diversas aplicações como curativos. Neste trabalho foram sintetizadas membranas de hidrogéis com poli $(\mathrm{N}-2-$ pirolidona) (PVP), poli(álcool vinílico) (PVAI), quitosana e argila laponita em encapsulamento do fármaco para liberação controlada de glucantime sobre a superfície cutânea de tecidos lesados por leishmaniose. O tratamento tradicional dos pacientes infectados pelos parasitas é feito com antimoniato pentavalente de forma injetável. Entretanto estes antimoniatos são muito tóxicos e provocam efeitos colaterais nestes pacientes, além disso, pacientes portadores de doenças cardíacas e renais não podem fazer uso deste tratamento. No tratamento com membranas de hidrogéis aplicadas na superfície de tecidos lesados pela leishmaniose, o fármaco é liberado diretamente no ferimento de forma controlada, diminuindo os efeitos colaterais. As membranas preparadas neste trabalho foram caracterizadas por difração de raios $X(D R X)$, análise de termogravimetria (TG), intumescimento, fração gel, espectroscopia no infravermelho (FTIR), microscopia eletrônica de varredura (MEV) e microscopia de força atômica (AFM). As caracterizações funcionais foram feitas com teste de citotoxicidade e de liberação do fármaco "in vitro" e "in vivo", de acordo com o protocolo de ética do Instituto de Medicina Tropical do Hospital das Clinicas da Faculdade de Medicina da USP. O teste "in vivo" dessas membranas provou ser eficiente na liberação controlada de fármacos diretamente nas superfícies lesadas pela leishmaniose. Nos testes "in vivo" as membranas de PVP/PVAl/argila $1,5 \%$ e glucantime apresentaram evidente contribuição para redução do ferimento chegando a uma cura clínica.
\end{abstract}




\title{
OBTAINING MEMBRANES FOR ALTERNATIVE TREATMENT HYDROGELS OF CUTANEOUS LEISHMANIASIS
}

\author{
Maria José Alves de Oliveira
}

\begin{abstract}
Polymeric Hydrogels formed by crosslinked polymeric chains were obtained by ionizing radiation process according to Rosiak technique. In the last 40 years the use of hydrogels has been investigated for various applications as curatives. In this work hydrogel membranes were synthesized with poly (N-2-pyrrolidone) (PVP), poly (vinyl alcohol) (PVA), chitosan and laponita clay for use as a vehicle for controlled glucantime release on the surface of skin tissues injured by leishmaniasis. Leishmaniasis is a disease caused by a protozoan parasite of the genus Leishmania transmitted by the bite of phlebotomies sandfly. The traditional treatment of patients infected by these parasites is done with pentavalent antimony in injectable form. However, these antimonates are highly toxic and cause side effects in these patients. In addition, patients with heart and kidney disease can not use this treatment. In treatment with drug delivery hydrogel membrane applied on the surface of leishmaniasis injured tissues the drug is released directly to the wound in a controlled manner, reducing the side effects. Membranes prepared in this study were characterized by X-ray diffraction (XRD), thermogravimetric analysis (TG), swelling, gel fraction, infrared spectroscopy (FTIR), scanning electron microscopy (SEM) and atomic force microscopy (AFM). The characterizations of cytotoxicity and drug release were made "in vitro" and "in vivo" with functional test according to ethical protocol of the Division of Infectious and Parasitic Diseases at the Hospital of Clinics, São Paulo University-School of Medicine, University. The "in vivo" test of these membranes proved to be effective in controlled release of drugs directly into leishmaniasis damaged tissues. Results of "in vivo" tests using PVP/PVAI / clay 1,5\% and glucantime membrane showed remarkable contribution to wound reduction and cure in clinical therapy.
\end{abstract}




\section{Sumário}

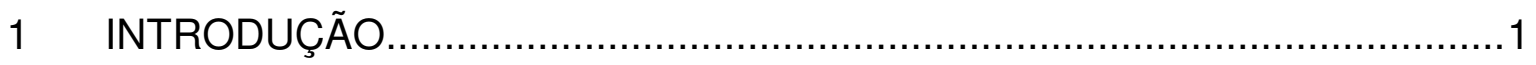

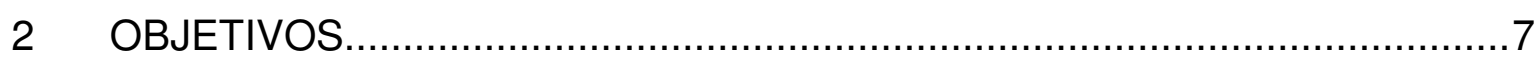

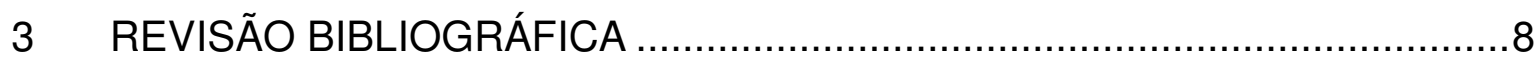

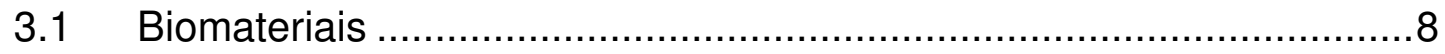

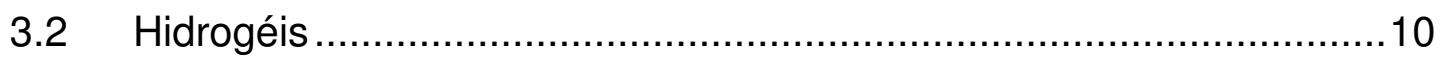

3.2.1 Hidrogéis por radiação ionizante ..........................................11

3.2.2 Hidrogéis com quitosana .................................................13

3.2.3 Hidrogéis com argila ........................................................14

3.2.4 Liberação controlada de drogas ..........................................15

3.2.5 Hidrogéis e liberação controlada .........................................17

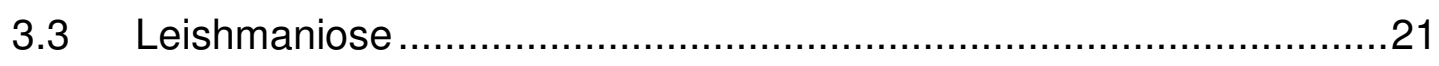

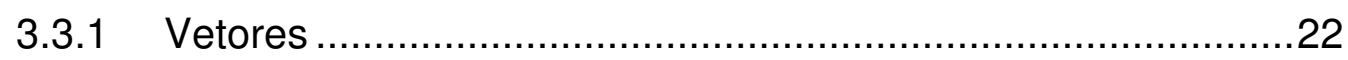

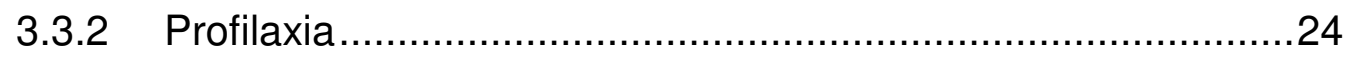

3.3.3 Diagnóstico da doença ........................................................25

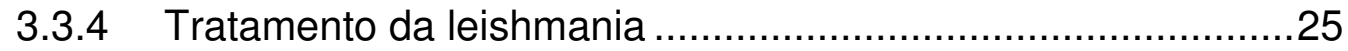

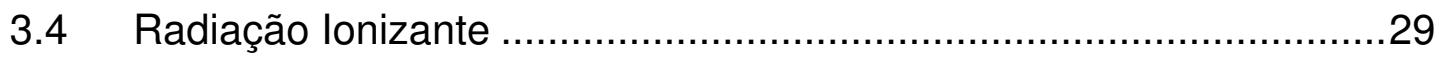

3.5 Poli (N-vinil-2-pirrolidona) (PVP) ..................................................

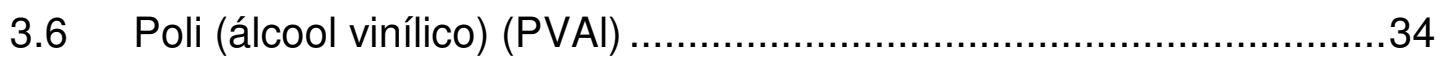

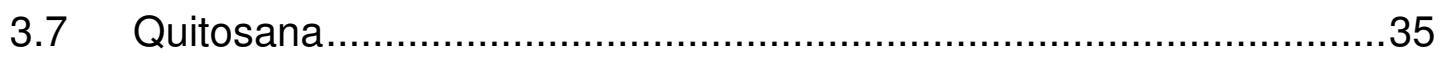

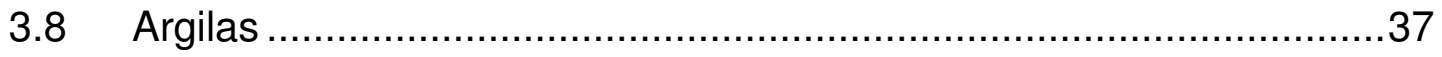

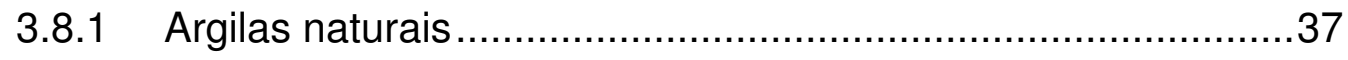


3.8.2 Argilas especiais comercialmente raras .38

3.8.3 Hectorita sintética ou laponita 38

3.8.4 Glucantime fármaco usado para liberação

4 MATERIAIS E MÉTODOS 43

4.1.1 Materiais e animais.

4.1.2 Métodos. .44

4.1.3 Reticulação por radiação ionizante. 49

4.2 CARACTERIZAÇÕES DOS HIDROGÉIS 49

4.2.1 Intumescimento .49

4.2.2 Fração gel. .49

4.2.3 Termogravimetria (TG) .50

4.2.4 Espectroscopia no Infravermelho (FTIR)...... .51

4.2.5 Difração de Raio X 52

4.2.6 Liofilização das membranas para as análises de microscopia eletrônica de varredura e microscopia de força atômica. .54

4.2.7 Microscopia eletrônica de varredura com emissão de campo (MEV-EC). 55

4.2.8 Espectrometria de energia dispersiva de raios X - EDS .... 55

4.2.9 Microscopia de força atômica (AFM) 56

4.2.10 Liberação do fármaco. 57

4.2.11 Citotoxicidade .59

4.3 Protocolo de Ética 62

4.3.1 Procedência dos modelos experimentais (camundongos Balb/C). 
4.3.2 Purificação de amastigotas

4.3.3 Inoculação dos modelos experimentais para uso das matrizes de hidrogéis com o glucantime

4.3.4 Avaliação de lesões dos camundongos Balb/C

5 RESULTADOS E DISCUSSÕES. 68

5.1 Resultados dos hidrogéis obtidos do sistema PVAl/PVP e PVAl/PVP/ argila - intumescimento e fração gel em triplicata. .70

5.2 Resultados dos hidrogéis obtidos dos sistemas PVAl/argila e PVP/ argila - intumescimento e fração gel. .72

5.3 Resultados dos hidrogéis obtidos de PVAl/quitosana/argila intumescimento e fração gel.

5.4 Resultados dos hidrogéis obtidos de PVP/quitosana/argila intumescimento e fração gel.

5.5 Caracterização dos sistemas por termogravimetria (TG e DTG) e espectroscopia no infravermelho (FTIR). .78

5.6 Estudo da intercalação da argila nos sistemas por difração de raios $X$

5.7 Estudo da morfologia dos sistemas por microscopia eletrônica de varredura com emissão de campo (MEV-EC).

5.8 Estudo da macrodispersão da argila por espectrometria de energia dispersiva de raios $X$ EDS

5.9 Estudo da nanodispersão da argila nos sistemas por microscopia de força atômica (AFM) 101

5.10 Citotoxicidade das membranas de hidrogéis 103

5.11 A extração do glucantime das membranas de hidrogéis analisada por espectrofotometria UV-visível $510 \mathrm{~nm}$. 107

5.12 Extração do glucantime das membranas de hidrogéis analisada por espectrometria de absorção atômica com atomização por forno de grafita (GF-AAS). 108 
6 RESULTADOS DO TRATAMENTO DOS ANIMAIS INOCULADOS COM AS AMASTIGOTAS (L. amazonenses) RESPONSÁVEIS PELA LEISHMANIOSE

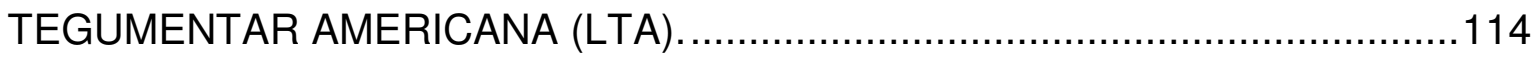

6.1 Grupo $1^{\circ}$ - Camundongos Balb/C tratado ……..........................114

6.2 Grupo 2 - Camundongos Balb/C tratados ……............................116

6.3 Grupo 3 - Camundongos Balb/C tratados ...................................117

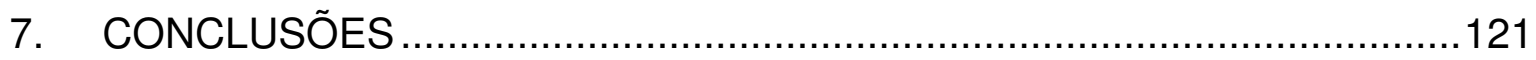

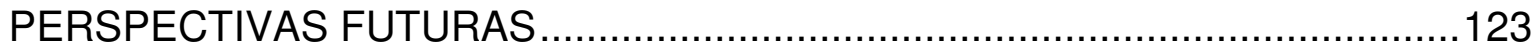

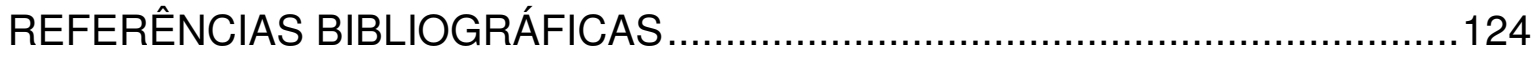

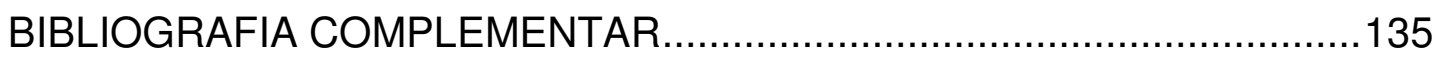

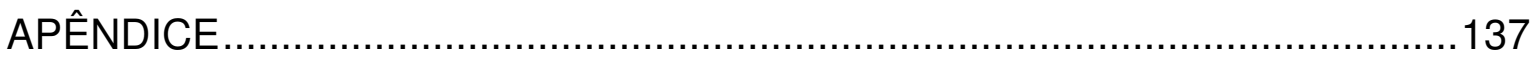




\section{SUMÁRIO DE FIGURAS}

FIGURA 1 - Várias estruturas moleculares: a) linear b) ramificado c) em forma de pente d) circular e) em forma de estrela f) dendrítica g) nano-microgel (S. Kadlubowski apresentação IRAP 2008).

FIGURA 2 - Representações dos hidrogéis (A) normal e (B) intumescido em solução aquosa.

FIGURA 3 - Representação esquemática de várias estruturas de nanocompósitos polímeros/argila: (a) Intercalada, (b) Esfoliada e (c) Intercalada-esfoliada (Carrado, 2003) 15

FIGURA 4 - Comparação da concentração plasmática efetiva do fármaco entre o sistema de liberação controlada de fármaco e o sistema de administração por dose convencional (Dumitriu, 1994).

FIGURA 5 - Exposição de um modelo de biomolécula encapsulada no hidrogel polimérico (Bayer e Peppas, 2008).

FIGURA 6 - Vetor fêmea alimentando-se de sangue e infectando o local da picada (FIOCRUZ, 2012).

FIGURA 7- Ciclo da transmissão da leishmaniose a evolução nos reservatórios e nos vetores (http://parasitophilia.blogspot.com.br/).

FIGURA 8 - Exemplo de lesões provocadas pela leishmaniose cutânea, (Vigilância Ambiental leishmaniose 2013). 28

FIGURA 9 - Esquema representativo de uma unidade de radiação gama por ${ }^{60} \mathrm{Co}$ (IAEA, 1992). .32

FIGURA 10 - Monômero Poli(N-vinil-2-pirrolidona) PVP. 33

FIGURA 11 - Estrutura dos radicais de PVP produzidos por radiação ionizante. .33 
FIGURA 12 - Reação de alcoólise do PVAc em meio alcoólico/alcalino. .34

FIGURA 13 - Tautomeria entre o álcool vinílico e acetaldeído. .34

FIGURA 14 - Monômero da quitosana, (Revista Químicas e Derivados 2006). ...37

FIGURA 15 - Fórmula estrutural ideal da laponita $R D$ (www.laponite.com). 40

FIGURA 16 - Desenho esquemático de um compósito de polímero com argila mostrando a morfologia de um compósito convencional e de um nanocompósito com morfologia intercalada (I), esfoliada (II) e com aglomerados (III) (Zheng, 2005). 40

FIGURA 17 - Proposta molecular do glucantime (www.bulas.med.br)..... 42

FIGURA 18 - Fluxograma das formulações para a obtenção da membrana .44

FIGURA 19 - Fluxograma da formulação para a obtenção da membrana. 45

FIGURA 20 - Fluxograma da formulação para a obtenção da membrana. .45

FIGURA 21- Sistema com balões acoplados para extração de fração gel. .50

FIGURA 22 - Imagem do aparelho de análise de termogravimetria (TG) 51

FIGURA 23 - Imagem do aparelho de Espectroscopia (FTIR). 52

FIGURA 24 - Imagem do aparelho difratômetro de raios X 52

FIGURA 25- As diferentes representações da dispersão da argila em relação ao polímero pela análise de DRX (A) só a argila (B) argila intercalada em relação ao polímero e (C) argila esfoliada em relação ao polímero 53

FIGURA 26 - Imagem do liofilizador de bancada. 54 
FIGURA 27 - Imagem do microscópio eletrônico de varredura por emissão de campo (MEV-EC). 55

FIGURA 28 - Imagem do aparelho de espectrometria de energia dispersiva de raios $X$ - EDS. 56

FIGURA 29 - Aparelho SOLVER (Scanning Probe Microscope) NT-MDT, alocado no laboratório Sicrontron (LNLS) Campinas -SP. 56

FIGURA 30 - Imagem da incubadora modelo TE-420 da TECNAL. 57

FIGURA 31 - Imagem do aparelho de espectrofotometria UV-visível. 58

FIGURA 32 - Curva de calibração de antimoniato ( $\mathrm{Sb} \mathrm{V}$ ) mostrando concentração versus absorbância em $\lambda=510 \mathrm{~nm}$. 58

FIGURA 33 - Espectrômetro de absorção atômica com atomização por forno de grafita. 59

FIGURA 34- Fluxograma do procedimento escolhido para a inoculação dos modelos experimentais.

FIGURA 35 - Fluxograma do procedimento escolhido para a inoculação dos modelos experimentais.

FIGURA 36- Fluxograma do procedimento escolhido para a inoculação dos modelos experimentais.

FIGURA 37 - As fotos apresentam a sequência dos curativos de hidrogéis ( $A$ e $B$ ).

FIGURA 38 - Membranas de hidrogéis com superfícies quebradiças. 68

FIGURA 39 - Esquema dos sistemas e sequência dos resultados 69 
FIGURA 40 - Curvas de intumescimento dos hidrogéis de PVAl/PVP/argila, obtidos por irradiação gama, dose de 25 kGy. 70

FIGURA 41 - Curvas de intumescimento das membranas de hidrogéis PVAl/argila, obtidos por radiação gama, dose de 25 kGy. .72

FIGURA 42 - Curvas de intumescimento das membranas de hidrogéis PVP/argila obtidos por irradiação gama, dose de 25 kGy....

FIGURA 43 - Curvas de intumescimento dos hidrogéis PVAl/quitosana/argila obtidos por radiação gama, dose de 25 kGy. 75

FIGURA 44 - Curvas de intumescimento das membranas de hidrogéis PVP/quitosana/argila, obtidos por irradiação gama, dose de 25 kGy. .77

FIGURA 45 - Curvas de TG das membranas de hidrogéis PVP/PVAl/argila, obtidas por irradiação gama, dose de 25 kGy.

FIGURA 46 - Curvas de DTG das membranas de hidrogéis PVP/PVAl/argila, obtidos por irradiação gama, dose de 25 kGy.

FIGURA 47 - Curvas de espectroscopia vibracional na região do infravermelho dos hidrogéis secos em forma de filmes PVAl/PVP/argila.

FIGURA 48 - Curvas de TG das membranas de hidrogéis PVAl/argila.

FIGURA 49 - Curvas de DTG das membranas de hidrogéis PVAl/argila. 82

FIGURA 50 - Curvas de TG das membranas de hidrogéis PVP/argila. 83

FIGURA 51 - Curvas de DTG das membranas de hidrogéis PVP/argila. 83

FIGURA 52 - Curvas de espectroscopia vibracional na região do infravermelho das membranas de hidrogéis secos em forma de filmes PVAl/argila. .84 
FIGURA 53 - Curvas de espectroscopia vibracional na região do infravermelho das membranas de hidrogéis secos em forma de filmes PVP/argila. 85

FIGURA 54 - Curvas de TG das membranas de hidrogéis PVAl/quitosana/argila.

FIGURA 55 - Curvas de DTG das matrizes de hidrogéis PVAl/quitosana/argila, obtidos por radiação ionizante gama, dose de 25 kGy.

FIGURA 56 - Curvas de espectroscopia vibracional na região do infravermelho dos hidrogéis secos em forma de filmes PVAl/quitosana/argila.

FIGURA 57 - Curvas de TG das membranas de hidrogéis PVP/quitosana/argila, obtidos por irradiação gama, dose de 25 kGy.

FIGURA 58 - Curvas de DTG das membranas de hidrogéis PVP/quitosana/argila, obtidos por irradiação gama, dose de $25 \mathrm{kGy}$.

FIGURA 59 - Curvas de espectroscopia vibracional na região do infravermelho dos hidrogéis secos em forma de filmes PVP/quitosana/argila.

FIGURA 60- Curvas de DRX das membranas de hidrogéis de PVAI/PVP/argila..90

FIGURA 61 - Curvas de DRX das membranas dos hidrogéis de PVAl/argila.......90

FIGURA 62 - Curvas de DRX das membranas dos hidrogéis de PVP/argila

FIGURA 63 - Curvas de DRX das membranas de hidrogéis de PVAl/quitosana/ 1,0 e $1,5 \%$ argila. .92

FIGURA 64 - Curvas de DRX das membranas de PVP/quitosana/argila. 93

FIGURA 65- Micrografia de MEV da membrana de hidrogel liofilizado de PVAl/ PVP. 
FIGURA 66 - Micrografia de MEV da membrana de hidrogel liofilizado (A) PVAI/ PVP $/ 1,0 \%$ de argila e (B) PVAl/PVP/1,5\% de argila

FIGURA 67 - Micrografias de MEV das membranas de hidrogéis liofilizados (A) PVAl $/ 1,0 \%$ argila e (B) PVAl $/ 1,5 \%$ de argila

FIGURA 68 - Micrografias de MEV com emissão de campo (MV-EC) das membranas de hidrogéis liofilizados (A) PVP/1,0\% argila e (B) PVP/1,5\% argila. 95

FIGURA 69 - Micrografias de MEV das membranas de hidrogéis liofilizados (A) PVAl/quitosana $/ 1,0 \%$ argila e (B) PVAl/quitosana/1,5\% argila.

FIGURA 70 - Micrografias de MEV das membranas de hidrogéis liofilizados (A) $P V P / q u i t o s a n a / 1,0 \%$ argila e (B) PVP/quitosana/1,5\% argila.

FIGURA 71 - (A) Micrografia de EDS e (B) gráfico com a porcentagem dos íons $\mathrm{Si}, \mathrm{Mg}, \mathrm{Sb}$ e Na dispersos na membrana de hidrogel de PVAl/PVP/argila 1,5\%. . 98

FIGURA 72 - (A) Micrografia de EDS e (B) gráfico com a porcentagem dos íons $\mathrm{Si}, \mathrm{Mg}, \mathrm{Sb}$ e $\mathrm{Na}$ dispersos na membrana de hidrogel de PVAI/0,5\% argila. .98

FIGURA 73 - (A) Micrografia de EDS e (B) gráfico com a porcentagem dos íons $\mathrm{Si}, \mathrm{Mg}, \mathrm{Sb}$ e $\mathrm{Na}$ em membrana de hidrogel de $\mathrm{PVP} / 1,5 \%$ argila. 99

FIGURA 74 - (A) Micrografia de EDS e (B) o gráfico com a porcentagem dos íons $\mathrm{Si}, \mathrm{Mg}, \mathrm{Sb}$ e $\mathrm{Na}$ dispersos na membrana de hidrogel de PVAl/quitosana/1,5\% argila. 100

FIGURA 75- (A) Micrografia de EDS e (B) gráfico com a porcentagem dos íons Si, $\mathrm{Mg}, \mathrm{Sb}$ e Na dispersos na membrana de hidrogel de PVP/quitosana/1,5\% argila.

FIGURA 76 - MFA obtida da superfície das membranas de hidrogéis liofilizados PVP/PVAl $/ 1,0 \%$ de argila. 101 
FIGURA 77 - MFA obtida da superfície das membranas de hidrogéis liofilizados de PVAl $1,0 \%$ argila.

FIGURA 78 - MFA obtida da superfície das membranas de hidrogéis liofilizados de PVP $/ 1,0 \%$ argila. 102

FIGURA 79 - MFA obtida da superfície da amostra das membranas de hidrogéis liofilizados de PVAl/quitosana $/ 1,0 \%$ de argila.

FIGURA 80 - MFA obtidas da superfície da amostra das membranas de hidrogéis liofilizados de PVP/quitosana 1,0\% argila.

FIGURA 81 - Curva de viabilidade celular no ensaio de citotoxicidade pelo método de incorporação do vermelho neutro, da membrana de hidrogel obtida por PVP/PVAl/argila, reticulada por radiação gama, dose de 25 kGy. 104

FIGURA 82 - Curva de viabilidade celular no ensaio de citotoxicidade pelo método de incorporação do vermelho neutro, da membrana de hidrogel obtida por PVAl/argila, reticulado por radiação gama, dose de 25 kGy. 105

FIGURA 83 - Curva de viabilidade celular no ensaio de citotoxicidade pelo método de incorporação do vermelho neutro, da membrana de hidrogel obtida por PVP/ argila, reticulado por radiação gama, dose de 25 kGy. 105

FIGURA 84 - Curva de viabilidade celular no ensaio de citotoxicidade pelo método de incorporação do vermelho neutro, da membrana de hidrogel obtida por PVAl/quitosana/argila, reticulado por radiação gama, dose de 25 kGy. 106

FIGURA 85 - Curva de viabilidade celular no ensaio de citotoxicidade pelo método de incorporação do vermelho neutro, da membrana de hidrogel obtida por PVP/quitosana/argila, reticulado por radiação gama, dose de 25 kGy. 106

FIGURA 86 - Curvas de liberação do fármaco glucantime das membranas de hidrogel (A) PVP/PVAl (B) PVP/PVAl/argila (C) PVAl/argila (D) PVP/argila (E) PVAl/quitosana/argila (F) PVP/quitosana/argila. 
FIGURA 87 - Curvas da cinética da liberação do glucantime das matrizes de hidrogéis (A) PVP/PVAI, (B) PVP/PVAl/1,5\%argila, (C) PVAl/1,5\%, (D) PVP/1,5\% argila, (E) PVAl/quitosana/1,5\% argila e (F) PVP/quitosana/1,5\% argila.

FIGURA 88 - Grupo 1 lesão cutânea na pata dos modelos experimentais (A e B) controles sem tratamento.

FIGURA 89 - Grupo 1 redução da lesão cutânea na pata dos modelos experimentais (A e B) tratados com membrana de PVAl/PVP/glucantime. 115

FIGURA 90 - Grupo 1 lesão cutânea na pata dos modelos experimentais (A e B) tratados com membrana de PVAI/PVP sem glucantime.

FIGURA 91 - Grupo 2 lesão cutânea na pata dos camundongos controles (A e B), sem tratamento.

FIGURA 92 - Grupo 2 redução da lesão cutânea na pata dos camundongos Balb/C (A e B) tratados com PVAl/PVP/1,5\%argila/glucantime.

FIGURA 93 - Grupo 3 redução da lesão cutânea na pata dos camundongos ( A e B) tratados com PVAl/PVP/glucantime. 118

FIGURA 94 - Grupo 3 redução da lesão cutânea na pata dos camundongos (A e B) tratados com PVAl/PVP/1,5\% de argila / glucantime 118

FIGURA 95 - Grupo 3 redução da lesão cutânea na pata dos camundongos (X controle sem tratamento) versus (A tratados com PVAl/PVP/1,5\% de argila/glucantime.

Figura 97 - Curva da quitosana pura.

Figura 98 - Curva do PVP puro.

Figura 99 - Curva do filme de PVAl puro. 


\section{SUMÁRIO DE TABELAS}

TABELA 1 - Exemplo de produtos à base de hidrogéis poliméricos encontrados no mercado para tratamento de lesões. 20

TABELA 2 - Estrutura química de antimoniais empregados na clínica médica para o tratamento das leishmanioses, com respectivos nomes químicos (Rath, 2003).

TABELA 3 - Composição química da argila laponita sintética (seca) (www.laponite.com).

TABELA 4 - Propriedades físicas da laponita sintética (seca) (www.laponite.com).

TABELA 5 - Formulação PVAl/PVP/argila.

TABELA 6 - Formulação PVAl/argila. 46

TABELA 7 - Formulação PVP/argila. 47

TABELA 8 - Formulação PVAl/quitosana/argila. 47

TABELA 9 - Formulação PVP/quitosana/argila. 48

TABELA 10 - Apresentação do esquema da distribuição dos extratos das amostras e controle na microplaca. .61

TABELA 11- Fração gel dos hidrogéis PVAl/PVP/argila, obtidos por irradiação gama, na dose de $25 \mathrm{kGy}$. .71

TABELA 12 - Fração gel das membranas de hidrogéis PVAl/argila e PVP/argila, obtidos por irradiação gama com dose de $25 \mathrm{kGy}$. 
TABELA 13 - Fração gel dos hidrogéis PVAl/quitosana/argila, obtidos por irradiação gama, dose de 25 kGy. .76

TABELA 14 - Fração gel dos hidrogéis PVP/quitosana/argila, obtidos por irradiação gama, dose de 25 kGy. .78

TABELA 15 - Principais picos de infravermelho encontrados nas membranas de hidrogéis poliméricos PVAl/PVP e argila, $\delta=$ deformação e $V=$ estiramento. $\ldots . .80$

TABELA 16 - Concentrações do fármaco glucantime solução padrão e solução irradiada em dose de $25 \mathrm{kGy}$. 108

TABELA 17 - Resumo dos grupos de camundongos Balb/C tratados com e sem glucantime. 120

TABELA 18 - Concentração de antimoniato $\mu \mathrm{g} \mathrm{mL}^{-1}$ liberado pelas membranas de hidrogéis PVP/PVAl e PVP/PVAl/argila. Pela técnica de Espectrometria de Absorção Atômica com Atomização por Forno de Grafita (GF-AAS). 137

TABELA 19 - Concentração de antimoniato $\mu \mathrm{g} \mathrm{mL}^{-1}$ liberado pelas membranas de hidrogéis PVAl/argila e PVP/argila. Pela técnica de Espectrometria de Absorção Atômica com Atomização por Forno de Grafita (GF-AAS) 137

TABELA 20 - Concentração de antimoniato $\mu \mathrm{g} \mathrm{mL}^{-1}$ liberado pelas membranas de hidrogéis PVAl/quitosana/argila e PVP/quitosana/argila. Pela técnica de Espectrometria de Absorção Atômica com Atomização por Forno de Grafita (GFAAS). 138

TABELA 21 - Concentração de antimônio $\mu \mathrm{g} \mathrm{mL}^{-1}$ liberado pelas membranas de hidrogéis PVP/PVAl e PVP/PVAl/argila. Pela técnica de Espectrometria de Absorção Atômica com Atomização por Forno de Grafita (GF-AAS), modo estático. 138 
TABELA 22 - Concentração de antimônio $\mu \mathrm{g} \mathrm{mL}^{-1}$ liberado pelas membranas de hidrogéis PVAl/argila e PVP/argila. Pela técnica de Espectrometria de Absorção Atômica com Atomização por Forno de Grafita (GF-AAS). 139

TABELA 23 - Concentração de antimônio $\mu \mathrm{g} \mathrm{mL}^{-1}$ liberado pelas membranas de hidrogéis PVAl/argila e PVP/argila. Espectrometria técnica de Absorção Atômica com Atomização por Forno de Grafita (GF-AAS), para PVAl/quitosana/argila e PVP/quitosana/argila. 139 


\section{LISTA DE ABREVIAÇÃO E SIMBOLOS}

MFA Microscopia de Força Atômica

ATCC American Type Culture Coletion

CCTM Centro de Ciência e Tecnologia de Materiais

CGEE Centro de Gestão e Estudos Estratégicos

hkl Índice de Miller da estrutura cristalina

DOs Leituras de densidade óptica

EDS Espectrometria de Energia Dispersiva de Raios $\mathrm{X}$

DRX Difração de Raios X

DTG Derivada da curva de termogravimetria

FTIR Espectroscopia no Infravermelho com transformada de Fourrier

GF-AA Espectrômetro de Absorção Atômica com atomização por forno de grafita

$\mathrm{HCl} \quad$ Ácido clorídrico

HDPE Polietileno de alta densidade

IC50\% Índice de citotoxicidade

IMT-USP Instituto de Doenças Tropicais da Universidade de São Paulo

kGy unidade de dose de radiação

LIM/46 Laboratório de Investigação Médica do HCFMUSP

LTA Leishmaniose Tegumentar Americana

LVA Leishmaniose visceral Americana 
MEV-EC Microscopia Eletrônica de Varredura com emissão de campo

MEM Eagle extrato

MEV Microscopia Eletrônica de Varredura

NCTC Células de tecido conectivo de camundongo

PEG Poli(glicol etilênico)

PBS Solução tampão

PVAl Poli(álcool vinilíco)

PVAc Poli(acetato de vinila)

PVP Poli(N-vinil-2-pirrolidona)

$\mathrm{R}^{\bullet} \quad$ Radical livre de iniciação

$\mathrm{RM}^{\bullet} \quad$ Cadeia intermediaria propagando-se

rpm Rotação por minuto

$\mathrm{Sb}(\mathrm{V}) \quad$ Antimoniato pentavalente

$\mathrm{Sb}$ (III) Antimoniato trivalente

$\mathrm{T}^{\bullet} \quad$ Radical não propagado

TG Termogravimetria

UV Luz ultravioleta

$\wedge$ Lambda representa comprimento de onda da radiação incidente 
Biomateriais compõem uma área da ciência em que materiais sintéticos são desenvolvidos para funções biologicamente pertinentes, proporcionando grande diversidade de novos produtos.

Estima-se que o mercado mundial para biomateriais movimente aproximadamente 35 bilhões de dólares todo ano. Além disso, este mercado apresenta crescimento de $11 \%$ ao ano, o que demonstra a grande necessidade deste tipo de produtos. Embora sejam largamente empregados, ainda precisam ser aperfeiçoados para fins terapêuticos. Isto é evidente quando se faz um paralelo entre o desempenho dos biomateriais com o dos órgãos ou partes do corpo que eles devem substituir ou tratar. Porém, os biomateriais melhoram significativamente a qualidade de vida de milhões de pessoas, que de outra forma, estariam condenadas às limitações no desempenho de atividades ou até mesmo, em última análise, à morte (Conferência Nacional de Ciência, 2004; Onuki, 2008; CGEE, 2010). Entre esses biomateriais destacam-se os nanogéis, microgéis e macrogéis poliméricos, que são objeto de investigação como carregadores de fármacos.

Tem sido investigados por vários pesquisadores, entre eles Peppas (2008), o desenvolvimento de sistemas inteligentes de administração de medicamentos para o tratamento de doenças crônicas. Isso se tornou uma meta importante para várias empresas farmacêuticas. Observa-se que nas últimas décadas têm sido realizadas várias mudanças na investigação para 0 desenvolvimento do sistema de liberação de fármaco (Mohamad AL-Sheikhly, 2008; Ulanski, 2002). Este novo campo é conhecido como "terapia inteligente", que envolve dispositivos com administração de medicamentos com sistemas que detectam, isolam e tratam o local afetado pela doença, sem interferir no sistema biológico, melhorando a qualidade de vida do paciente (Peppas, 2006). A utilização de polímeros inteligentes moldados em escala molecular, com 
capacidade de liberar fármacos ou enzimas, tem sido reconhecida como um grande avanço na área biomédica (Ulansk, 2004; Rosiak, 2004; Vitaliy, 2007).

$\mathrm{Na}$ atualidade, o estudo da ciência dos polímeros considera a ciência biomédica como sendo uma das áreas de aplicação de grande importância, estabelecendo como finalidade as modificações de estruturas poliméricas na obtenção de novos materiais, como cateteres, marca-passos, tecidos substitutivos, imobilização celular, cartilagem para reconstrução de juntas, próteses superiores, próteses inferiores, hidrogéis, entre outros materiais. Estes hidrogéis são materiais usados como suportes na investigação de sistemas inteligentes para liberação de drogas. A utilização de polímeros sintéticos e naturais modificados tem estimulado a aplicação da nanotecnologia em sistemas poliméricos formados por novas estruturas (Peppas, 2006). Existem várias técnicas para a modificação de polímeros, entre elas a radiação ionizante que tem demonstrado grande eficiência nessas modificações no decorrer dos anos (JagurGrodzinski, 2010).

Além do processo da radiação ionizante para a modificação de polímeros, recentemente têm sido usadas nanopartículas inorgânicas, para a formação de nanocompósitos poliméricos. Especialmente os nanocompósitos de polímeros com argilas naturais e sintéticas têm despertado o interesse de vários pesquisadores para a possibilidade da obtenção de novos materiais, entre esses materiais estão os hidrogéis (Lee, 2009). Estas nanopartículas inorgânicas representam uma alternativa racional para polímeros convencionais, pois empregando-se uma pequena porcentagem de argila é possível formar polímeros com melhores propriedades mecânicas, boa transparência, maior estabilidade térmica e baixa permeabilidade a gases (Fonseca, 2003).

Os hidrogéis são materiais poliméricos modificados por reticulação, formados por redes tridimensionais. Quando soluções poliméricas diluídas são submetidas à radiação ionizante, estes polímeros são reticulados organizando segmentos internos da cadeia macromolecular que formam o nanogel. Por outro lado, microgéis e macrogéis são favorecidos quando soluções poliméricas 
concentradas são submetidas a doses moderadas proporcionando reações intermoleculares.

Os hidrogéis podem ser diferenciados em suas interações físicas e químicas de acordo com sua reticulação. Esses hidrogéis se mantêm em uma fase de transição de intumescimento de acordo com as necessidades de aplicações (Ulanski, 2007), contendo em sua composição $75 \%$ a $82 \%$ de água (ABD EL-MOHDY e Ghanem, 2009). Se submetidos ao intumescimento, podem aumentar de volume em até $300 \%$ em água ou fluídos biológicos, sem romper suas estruturas e sem modificar suas características físico - químicas.

Portanto, a inovação proposta no presente trabalho foi investigar membranas de hidrogéis de poli(N-vinil-2-pirrolidona) (PVP), Poli(álcool vinílico) (PVAl), com quitosana, um polímero de origem natural, e argila laponite sintética. Essas membranas foram obtidas por reticulação gama em cujo processo reticula-se e esteriliza-se concomitantemente. É inovador também a investigação do comportamento dessas membranas como veículo de liberação do fármaco glucantime "in vitro" e "in vivo", para oferecer uma forma alternativa de tratamento de uso tópico nas lesões provocadas pela leishmaniose cutânea, desta forma controlando a dosagem do fármaco na corrente sanguínea, diminuindo a citotoxicidade provocada pela dosagem injetável.

A quitosana e a argila laponite apresentam características interessantes para a obtenção de hidrogéis. A quitosana é um polímero natural de baixo custo e favorece as reticulações intramoleculares, intermoleculares e ligações catiônicas. Essas interações formam redes tridimensionais maiores ou menores que podem ser controladas de acordo com a necessidade de uso para o tratamento. Por sua vez, as argilas modificadas permitem interações catiônicas entre esta e determinados fármacos, o que pode ser usado em processos de liberação controlada. Sua intercalação com o polímero pode retardar a liberação do fármaco. Na literatura não consta a investigação desta combinação entre PVAl, $\mathrm{PVP}$, quitosana e argila para liberação de fármaco para o tratamento alternativo da leishmaniose. 
A leishmaniose tegumentar americana (LTA) (leishmaniose cutânea) é causada por um protozoário do gênero leishmania transmitido por mosquitos flebotomíneos (Amato, 2008). É uma antropozoonose considerada um grande problema de saúde pública e representa um complexo de doenças com importante espectro clínico e diversidade epidemiológica. A Organização Mundial da Saúde (OMS) estima que 350 milhões de pessoas estejam expostas ao risco com registro aproximado de dois milhões de novos casos por ano, das diferentes formas clínicas, a cutânea, muco cutânea e visceral. A leishmaniose tegumentar americana (LTA) tem ampla distribuição mundial e no Continente Americano há registro de casos desde o extremo sul dos Estados Unidos até o norte da Argentina, com exceção do Chile e Uruguai (Manual de Vigilância L.T.A. 2007).

No Brasil, a leishmaniose tegumentar americana (LTA), é uma doença com diversidade de agentes, de reservatórios e de vetores que apresentam diferentes padrões de transmissão e um conhecimento ainda limitado sobre alguns aspectos, o que a torna de difícil controle. Propõe-se à vigilância sanitária um monitoramento em unidades territoriais, definidas como áreas de maior ocorrência da doença, bem como, suas características ambientais, sociais e econômicas, buscando um conhecimento amplo e intersetorial (Biblioteca Virtual em Saúde, 2008). Mostrando a importância do controle da proliferação da doença, em algumas regiões brasileiras. No Brasil já se identifica um número de óbitos maior do que aquele causado pela dengue (Pronin, 2012).

A L. (Viannia) braziliensis foi a primeira espécie de Leishmania descrita como agente etiológico da LTA. É a mais importante, não só no Brasil, mas em toda a América Latina. Tem ampla distribuição, desde a América Central até o norte da Argentina. Esta espécie está amplamente distribuída em todo país.

O parasita foi isolado de roedores silvestres (Bolomys lasiurus, Nectomys squamipes) no Pernambuco, felídeos (Felis catus) no Rio de Janeiro, canídeos (Canis familiaris) no Ceará, Bahia, Espírito Santo, Rio de Janeiro e São Paulo e equídeos (Equus caballus, Equus asinus) nos estados do Ceará, Bahia e Rio de Janeiro. Embora o papel desempenhado por estes animais no ciclo de transmissão ainda não tenha sido bem definido, as evidências indicam, apenas, 
que os roedores silvestres são prováveis reservatórios primários dessa Leishmania. A eco-epidemiologia da LTA associada a L. (V.) braziliensis vem assumindo características distintas no decorrer do tempo nos diferentes biomas do país.

A Leishmania (Leishmania) amazonensis descrita como agente etiológico da LTA, ocorre em áreas de florestas primárias e secundárias da Amazônia Legal (Amazonas, Pará, Rondônia, Tocantins e Maranhão), e também é verificada nos estados das regiões Nordeste (Bahia), Sudeste (Minas Gerais e São Paulo), Centro-Oeste (Goiás) e Sul (Paraná).

O parasita foi isolado de roedores silvestres do gênero Proechymis e o Oryzomys. Embora o papel desempenhado por estes animais silvestres no ciclo de transmissão ainda não tenha sido bem definido, as evidências encontradas indicam estes roedores como reservatórios desta espécie de Leishmania. Seu principal vetor, L. flaviscutellata, apresenta ampla distribuição geográfica, sendo encontrado em diferentes habitats de países fronteira ao Brasil e nos estados do Acre, Amapá, Amazonas, Pará, Rondônia, Roraima, Tocantins, Bahia, Ceará, Maranhão, Distrito Federal, Goiás, Mato Grosso, Mato Grosso do Sul, Espírito Santo, Minas Gerais e São Paulo. (Manual de Vigilância L.T.A. 2007).

O ferimento causado pela leishmaniose cutânea tem características diferentes dos ferimentos comuns provocados por fungos e bactérias. Não pode ser usado tratamento tópico, como antibióticos ou anti-inflamatórios, apenas pode ser lavado com água. O paciente com lesões causadas pela leishmaniose que apresenta problemas renais ou cardíacos não pode usar o tratamento à base de antimoniatos (glucantime), ficando com as lesões sem tratamento, devido à toxicidade do fármaco injetado diretamente na corrente sanguínea.

Diante das informações da complexidade do tratamento das lesões provocadas pela leishmaniose cutânea, surgiu a proposta de oferecer uma forma alternativa de tratamento, utilizando uma matriz de polímero modificado por radiação como veículo de liberação do antimoniato diretamente no local afetado pelo ferimento. Essa matriz é um hidrogel de forma macia, úmida que libera o 
fármaco de forma lenta diminuindo a quantidade do antimoniato na corrente sanguínea, evitando a agressão da toxicidade no organismo do paciente. Desse modo, o presente trabalho avalia a ação do medicamento no modelo experimental Balb/C infectado com L. amazonensis. 


\section{OBJETIVOS}

Os objetivos do presente trabalho são:

- Sintetizar e caracterizar membranas contendo poli(álcool vinílico) (PVAl) / poli(N-vinil-2-pirrolidona) (PVP) e quitosana alternando os polímeros para obter hidrogéis com formulações diferentes, por processo de radiação ionizante de fonte gama.

- Adicionar nanopartículas de argila para diferenciar na matriz polimérica a liberação de fármaco glucantime.

- Estudar o desempenho terapêutico das membranas em diferentes concentrações de fármaco na aplicação biomédica de liberação de glucantime no tratamento da leishmaniose cutânea, "in vitro" e "in vivo" em camundongos Balb/C. 


\subsection{Biomateriais}

Os biomateriais vêm ganhando relevância e proporcionando a geração de inúmeras pesquisas com diversos tipos de substâncias. No mundo todo o grande destaque em tratamentos com estes materiais tem ocorrido principalmente por causa do sucesso determinado pelas respostas terapêuticas. Estima-se que existam cerca de 300.000 produtos denominados biomateriais que são utilizados na área da saúde. Embora sejam largamente empregados, ainda precisam ser aperfeiçoados para fins terapêuticos.

Por serem promissores, os biomateriais terão estabilidade de investimentos financeiros para a área biomédica, importante para a tecnologia de fabricação de novos materiais nos próximos vinte anos (Jing, 2007). Entre esses novos materiais se destacam a modificação de polímeros sintéticos e naturais para a obtenção de novos produtos para uso biomédico (Hoare e kohane, 2008; CGEE, 2010). A utilização de radiação ionizante tem demonstrado no decorrer dos anos, progressos nas modificações de polímeros para várias aplicações, entre elas a investigação de sistemas inteligentes para liberação de drogas (Jeszka, 2006; Bayer e Peppas, 2008; Kadlubowski, 2003).

As propriedades de biomateriais como os nanocompósitos poliméricos podem ser modificadas usando-se substâncias chamadas agentes reticulantes. Estes reticulantes irão reagir com os polímeros formando redes tridimensionais com maior estabilidade para o material (Sung, 1999). As modificações estruturais em polímeros têm sido de grande interesse tanto comercial quanto científico, para a obtenção de materiais de uso farmacêutico e biomédico. Essas modificações também podem ser obtidas adicionando-se um segundo polímero e posteriormente submetendo-se à radiação gama (Rosiak, e Ulanski, 1998; Lakouraj, 2005, Lozinsky, 2000). Pode-se modificar estruturalmente um polímero 
por meio da reticulação por agente químico (catalisador) (Lee e Mooney, 2001; Tomme, 2008; Ruiz, 2001; Wang, 2004), radiação de feixe de elétrons (Atta, 2008; Chemielewski, 2007), efeito fenton (Inokuti, 1996) e radiação no ultravioleta (Catalani, 2004).

Os polímeros são encontrados com diversas estruturas moleculares e quando submetidos à radiação gama $(\gamma)$ formam radicais que podem sofrer reações intramoleculares dando origem aos nanogéis. Os nanogéis são formados quando os radicais da mesma cadeia polimérica se recombinam entre si intramolercularmente, modificando-se a estrutura do polímero (Rosiak, 2005). E a interação intermolecular é a recombinação dos radicais, entre diferentes cadeias poliméricas na formação das distintas redes tridimensionais, conforme FIG. 1.

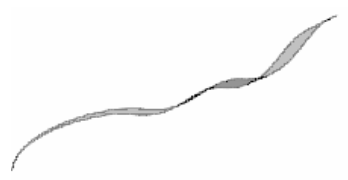

a)

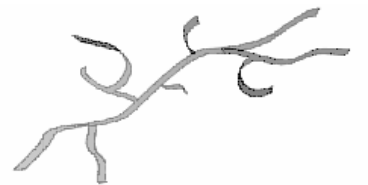

b)

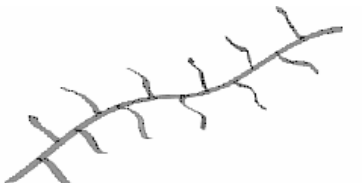

c)

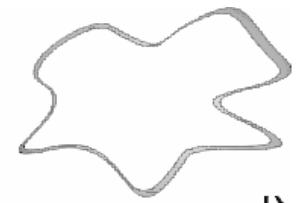

d)

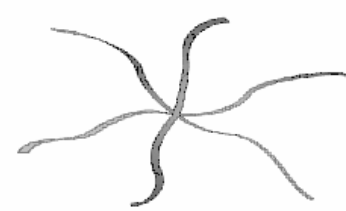

e)

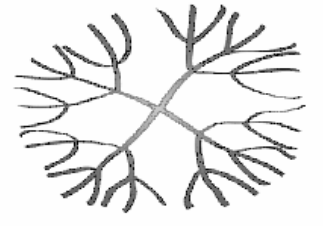

f)

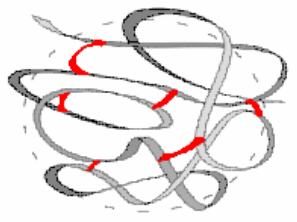

g)

FIGURA 1 - Várias estruturas moleculares: a) linear b) ramificado c) em forma de pente d) circular e) em forma de estrela f) dendrítica g) nano-microgel ( $S$. Kadlubowski apresentação IRAP 2008).

Para a modificação de polímeros, além do processo reticulante e da radiação ionizante, têm sido empregadas nanopartículas inorgânicas, para a formação de nanocompósitos poliméricos. Os nanocompósitos que resultaram da combinação de argila e polímeros têm atraído grande atenção de vários pesquisadores nos últimos anos, porque a combinação de moléculas orgânicas e íons inorgânicos oferecem perspectivas de novos produtos (Nair, 2007). 


\subsection{Hidrogéis}

Hidrogéis são materiais poliméricos modificados por reticulação, formados por redes tridimensionais. São caracterizados por sua hidrofilicidade e insolubilidade em água. Em meio aquoso, esses hidrogéis intumescem (ou incham) até um volume de equilíbrio, mas preservam sua integridade. A hidrofilicidade é devida à presença de grupos $-\mathrm{OH},-\mathrm{COOH},-\mathrm{CONH},-\mathrm{SO}_{3} \mathrm{H}$, entre outros presentes na cadeia polimérica (Bavaresco, 2002).

A insolubilidade e a estabilidade desses hidrogéis são devidas à formação da rede tridimensional. $O$ intumescimento resulta de um balanço entre as forças de dispersão atuando nas cadeias hidratadas e as forças coesivas devido às ligações covalentes cruzadas. Outras interações características também estão presentes, entre elas as interações eletrostáticas e de dipolo-dipolo (Benamer, 2006), tornando-se o grau e a natureza das ligações cruzadas responsáveis por suas características no estado intumescido.

As propriedades mecânicas dos hidrogéis dependem principalmente da rigidez original das cadeias poliméricas, do tipo de retículo, da densidade das ligações cruzadas e do intumescimento como resultado do balanço hidrofílico e hidrofóbico (Lee, 2001). Eles podem ser obtidos por vários processos de reticulação, entre eles o processo térmico obtido por ciclos de congelamento e descongelamento formando retículos físicos, por reticulação química na presença de um catalisador e temperatura e por radiação ionizante de fonte gama formando radicais reativos.

O desenvolvimento dos hidrogéis como biomateriais teve início em 1960, com copolímeros de hidroxietilmetacrilato (HEMA), que surgiu como um material candidato para a manufatura de lentes de contato hidrofílicas e gelatinosas, substituindo as lentes de contato de vidro (Solanger, 1981). Por sua vez, surgiram outros polímeros que apresentaram características semelhantes como o PVAl, PVP, PEG.

Em 1976, Langer e Folkman (Solanger, 1982) mostraram que macromoléculas como os polipeptídios podiam ser liberadas a partir de matrizes 
de hidrogéis de pHEMA (HYDRON®) e de PVAl, embora os tempos de liberações com essas matrizes fossem bem menores comparados aos liberação de proteínas, a partir de copolímeros de acetato de vinila.

Um ano depois, Peppas e Merrill (Peppas, 1977a; Peppas, 1977b) sintetizaram PVAl reticulado por meio de radiação com feixe de elétrons, que tinha a capacidade de simular um tecido natural e prevenir a coagulação sanguínea. Os hidrogéis de PVAl foram escolhidos por possuir tensão superficial baixa e facilidade em se ligar covalentemente à heparina (substância que atua como anticoagulante). Possíveis aplicações para esse material foram sugeridas, tais como biomembranas para transporte seletivo de macromoléculas, devido a sua estrutura na forma de rede e a sua capacidade de modificar os tamanhos destas redes quando as condições de irradiação fossem variadas.

Membranas hidrofílicas à base de poli(N-vinil-2-pirrolidona) (PVP) são conhecidas por sua inércia química e propriedades adequadas a aplicações biomédicas. Membranas desse tipo foram patenteadas por Rosiak e colaboradores (1993) e são comercializadas desde 1990, por causa da sua hidrofilicidade, podendo ser utilizadas para a substituição de tecidos orgânicos ou para outras aplicações biomédicas (Lee, 2001). Essas membranas foram sintetizadas por diversas rotas no decorrer dos anos. Atualmente ainda são investigadas para a área de biomateriais, enquanto matrizes para suporte de liberação controlada de fármaco, enzimas, hormônios, antioxidante, entre outros princípios ativos.

\subsubsection{Hidrogéis por radiação ionizante}

A técnica de radiação ionizante por ser isenta de aditivos para a iniciação e simples controle de processo de reticulação, tornou-se uma ferramenta adequada para a síntese de hidrogéis. O grupo de pesquisadores composto por Rosiak e colaboradores, elaboraram técnicas permitindo a sínteses de géis com vários tamanhos de macromoléculas reticuladas internamente em microgéis e hidrogéis macroscópicos (Rosiak, 1999). 
Embora a capacidade de alguns polímeros diluídos em solução aquosa favoreça a reticulação quando submetidos à radiação ionizante, a interação que favorece a reticulação está relacionada essencialmente à uma função da sua estrutura química. $\mathrm{O}$ modo da reticulação pode ser controlado por uma seleção de concentração adequada de polímero, do tipo de irradiação (pulsos versus contínua) e da taxa de dose (Rosiak, 2003).

No item bibliografia complementar é apresentada pela ordem cronológica dos artigos uma relação de trabalhos referentes a hidrogéis desenvolvidos pela técnica de radiação ionizante no decorrer dos últimos 40 anos. Uma série de trabalhos que deram sustentação às investigações dos hidrogéis desenvolvidos pela técnica de radiação ionizante pelo grupo do Rosiak e por outros pesquisadores que também aderiram à mesma técnica no decorrer dos últimos anos.

Em publicações recentes a equipe representada por Rosiak e colaboradores continua investigando as potencialidades dos hidrogéis na área de nanotecnologia aplicada a novos produtos.

Os estudos dos hidrogéis como biomateriais por radiação ionizante estão ainda sendo investigados. A investigação com interesse em novos produtos destaca-se em hidrogéis com estímulos sensíveis. Esses sistemas de géis são capazes de alterar as suas propriedades (mudanças conformacionais de segmentos da cadeia de polímero com mudança em volume de gel e na fração de volume de líquido) com estímulos externos, tais como temperatura, $\mathrm{pH}$, força iônica, luz, campo elétrico ou alterações na concentração de uma determinada espécie de produto químico.

Devido às propriedades citadas, são testados para aplicações tais como: detectores, outdoors, válvulas químicas, filmes e sistemas de liberação controlada (Rosiak, 2010), são também investigados para aplicações de liberação controlada de fármacos. No exemplo da FIG. 2 o hidrogel submetido ao intumescimento pode aumentar de tamanho até $300 \%$ com água ou fluidos 
biológicos, sem comprometer suas estruturas e sem modificar suas características físico - químicas.
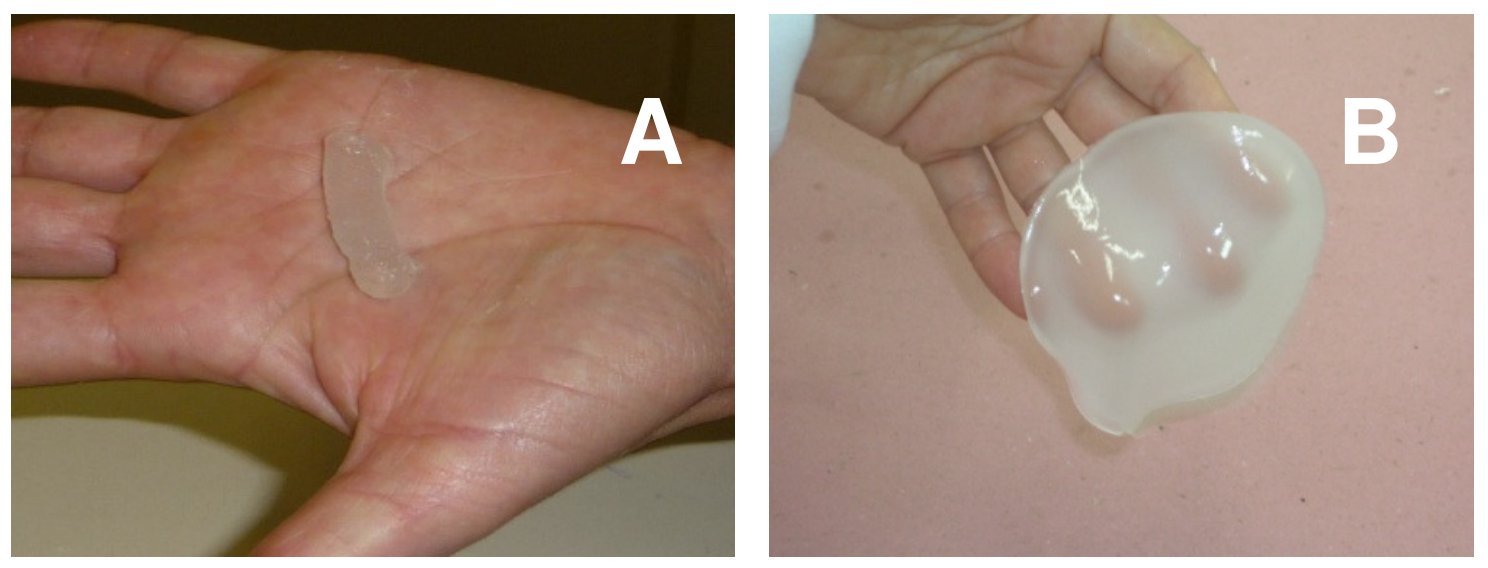

FIGURA 2 - Representações dos hidrogéis (A) normal e (B) intumescido em solução aquosa.

\subsubsection{Hidrogéis com quitosana}

As propriedades dos hidrogéis reticulados dependem principalmente da sua densidade de ligações cruzadas, notadamente influenciada pelo tipo de reticulação. A reticulação do hidrogel de quitosana pode ocorrer entre as cadeias da quitosana mesma, onde a reticulação envolve duas unidades estruturais que podem ou não pertencer à mesma cadeia, ou pode ser uma rede híbrida de polímero, onde a reação de reticulação ocorre entre a unidade estrutural de quitosana e uma cadeia de outro polímero (Jayakumar, 2005).

A quitosana por ser um polímero catiônico reage com componentes carregados, íons ou moléculas, conduzindo à formação de uma rede de ligações de caráter iônico entre as cadeias poliméricas. Segundo a literatura, em uma ligação cruzada iônica os grupos reagentes com a quitosana são íons ou moléculas com peso molecular bem definido (Gupta, 2007, Mansur, 2007; Sadahira, 2007; Neto, 2005; Berger, 2004; Lee, 1992).

A quitosana provou ser um excipiente seguro em formulações de drogas nas últimas décadas (Felt, 1998). Ela destacou-se como um mucoadesivo 
excelente no estado intumescido e por ser um polímero natural bioadesivo que pode aderir a tecido duro e a tecido macio. Também foi encontrada boa adesão em tecidos epiteliais e no revestimento de muco presente na superfície dos tecidos. O sistema de liberação com base em coloides (géis) de quitosana tem sido apresentado na literatura para liberação de drogas polares, péptidos, proteínas, vacinas e DNA em regiões de mucosas.

Testes clínicos realizados utilizando-se biomateriais com quitosana não relatam quaisquer reações inflamatórias ou alérgicas após implantação, aplicação de injeção tópica em pele humana ou ingestão (Berger, 2004). Os testes "in vitro" e "in vivo" apresentaram citocompatibilidade de filmes de quitosana com queratinócitos e fibroblastos demonstrando que o grau de desacetilação (GD) não tem influência significativa. Os filmes de quitosana com um GD baixo são muito bons para aplicação superficial, uma vez colocados sobre a lesão, aderem a fibroblastos e favorecem a proliferação de queratinócitos e regeneração da epiderme (Gupta, 2007).

Uma área próxima de estudo relacionado com a quitosana é a sua biodistribuição, em especial por meio de outros métodos de administração intravenosa. A distribuição de quitosana no organismo está relacionada com todos os aspectos da formulação da quitosana a partir do peso molecular e do GD e do tamanho da substância de liberação. Por outro lado, em uma formulação nanoparticulada, a cinética e biodistribuição inicialmente será controlada pelo tamanho e carga de nanopartícula e não por características estruturais da quitosana (Kato, 2000).

\subsubsection{Hidrogéis com argila}

Os hidrogéis com argila dispersa compõem uma nova classe de compósitos que combinam a elasticidade e a permeabilidade dos hidrogéis com a alta capacidade das argilas de adsorverem diferentes substâncias (Norma, 2005). Os nanocompósitos de argila esfoliadas são os que se destacam atraindo maior interesse, uma vez que apresentam maiores áreas superficiais que aumentam as interações entre o polímero e a argila, representados na FIG. 3. 

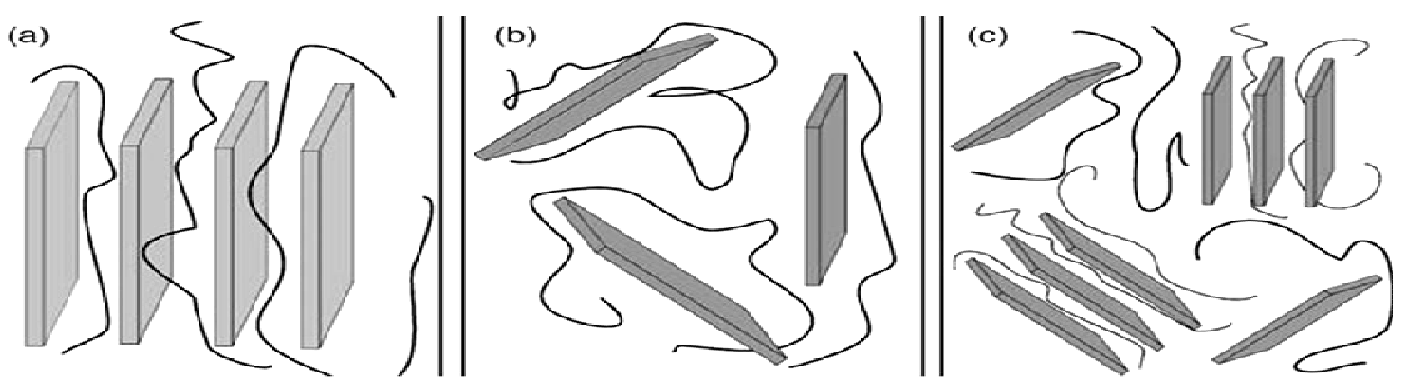

FIGURA 3 - Representação esquemática de várias estruturas de nanocompósitos polímeros/argila:

(a) Intercalada

(b) Esfoliada

e (c) Intercalada-esfoliada (Carrado, 2003).

O uso da argila como carga em compósitos poliméricos vem se destacando há alguns anos por apresentar maior estabilidade térmica, maior resistência física, entre outras propriedades. A investigação de hidrogéis com argila começa a aparecer com maior frequência e apresenta ainda poucas citações e poucos resultados publicados.

Em 2010 uma equipe de pesquisadores do Japão descobriu uma nova abordagem para a investigação de hidrogéis. Adicionaram argila a hidrogéis de poliacrilato de sódio e polietilenoglicol. Os hidrogéis resultantes apresentaram uma série de características que podem ser adaptadas a novas conformações dendríticas e com estímulos sensíveis, podendo regenerar-se após sofrer danos como furos ou cortes (Qigang, 2010).

\subsubsection{Liberação controlada de drogas}

O objetivo do sistema de liberação controlada é manter a concentração do fármaco entre os níveis máximo e mínimo de eficiência farmacêutica por um tempo prolongado, utilizando-se de uma única dosagem. A diferença de concentração plasmática efetiva em função do tempo, entre sistemas convencionais e de liberação controlada, pode ser visualizado na FIG. 4.

Embora os termos liberação sustentada ou liberação prolongada sejam muitas vezes confundidos ou substituídos por liberação controlada, significam características de revestimentos diferentes de formas farmacêuticas usadas para 
proteger a droga por mais tempo. Nas formas de liberação prolongada, a liberação do fármaco se dá por um maior período de tempo quando comparadas com os medicamentos usados pelos pacientes de formas convencionais. Entretanto, nas formas de liberação controlada, a velocidade de liberação do fármaco é mais precisamente controlada de acordo com a necessidade do tratamento (Ansel, 2007).

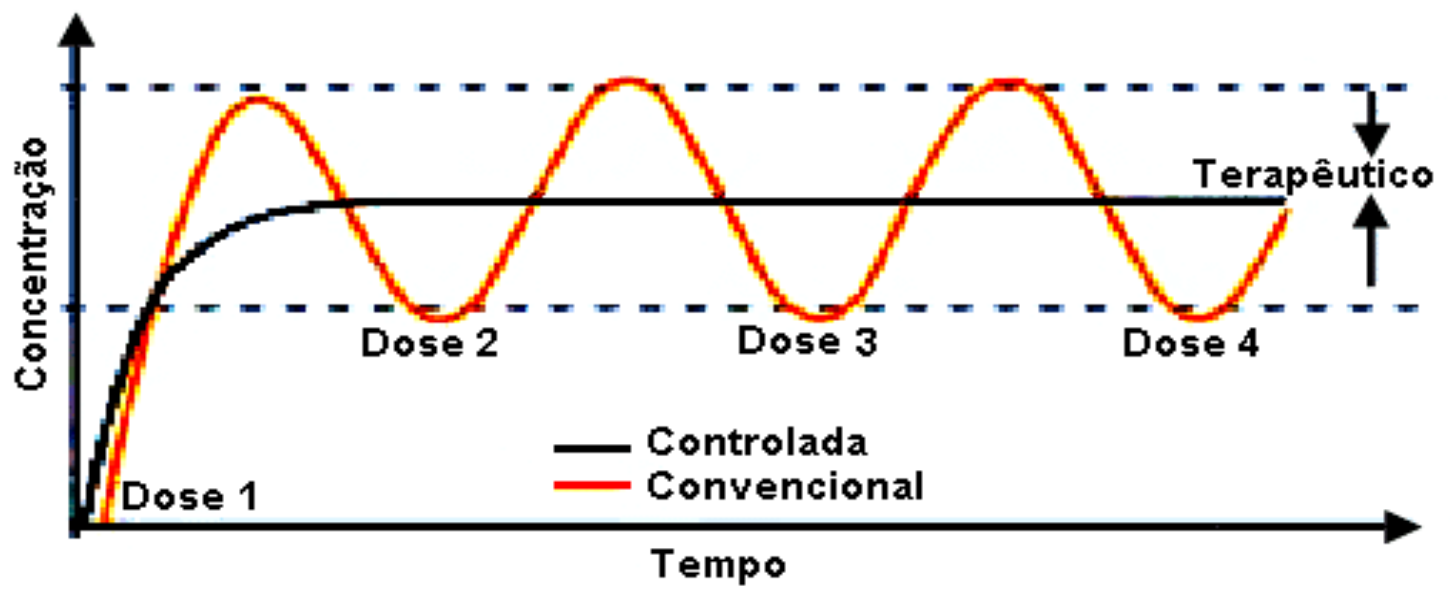

FIGURA 4 - Comparação da concentração plasmática efetiva do fármaco entre o sistema de liberação controlada de fármaco e o sistema de administração por dose convencional (Dumitriu, 1994).

As investigações da liberação de fármacos estão representadas pelas novas estratégias de veiculação de ingredientes ativos (Buenger, 2012), os quais incluem aplicações importantes da ciência de polímeros sintéticos e naturais (Kawashima, 2001; Lima, 2000), além da utilização de técnicas transdérmicas (Yano, 2002). Este empenho por parte de pesquisadores do mundo todo se justifica, pois sistemas de liberação controlada oferecem várias vantagens, entre elas, a liberação do fármaco diretamente no local do ferimento, diminuindo a toxicidade no organismo do paciente.

Quando o tratamento é em tumores o fármaco é liberado diretamente no local afetado sem danificar as células vizinhas, quando comparados aos sistemas convencionais de administração de fármacos (Jain, 2002). Nas formas de administração convencionais (spray, injeção, pílulas) a concentração da droga na corrente sanguínea apresenta um aumento, atinge um pico máximo e então 
declina. Como cada droga possui uma faixa de ação terapêutica acima da qual ela é tóxica e abaixo da qual ela é ineficaz, os níveis plasmáticos são dependentes das dosagens administradas. Este fato é problemático se a dose efetiva estiver próxima à dose tóxica.

\subsubsection{Hidrogéis e liberação controlada}

O progresso considerável nas sínteses e nas aplicações dos hidrogéis seguem duas áreas principais. Uma das áreas em que os hidrogéis mais atuam é o das matrizes poliméricas para liberação controlada de fármacos e outra em que os hidrogéis têm suma importância é a área de curativos para hidratação de ferimentos e queimaduras. Esses hidrogéis têm sido investigados e sua evolução tem revelado que os hidrogéis apresentam excelentes características para suportes de liberação de drogas e macromoléculas bioativas, como indicado na FIG. 5 (Bayer e Peppas, 2008), surgindo assim a idéia do sistema de liberação controlada, como um conceito promissor que deverá substituir as técnicas convencionais do uso de drogas.

Foram em decorrência do sucesso dessas propriedades e de suas aplicações avançadas que, nos últimos 40 anos, pesquisadores de renome como Nicholas Peppas, Janusz Rosiak, Edward Merrill, Robert Langer, Michael Sefton, Joseph Kost, Allan S. Hoffman e Richard Korsmeyer, Patterson, entre outros, voltaram seus estudos para esse campo (Peppas, 2013).

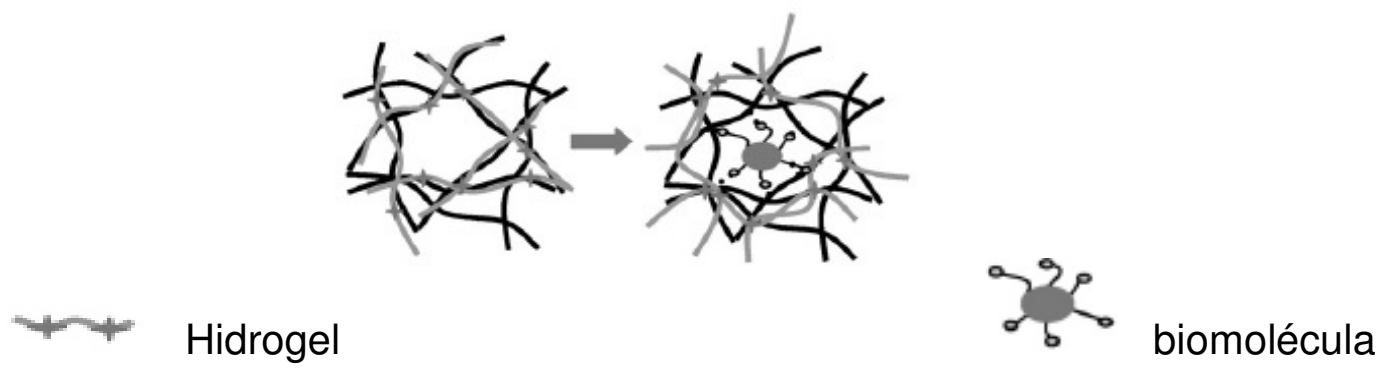

FIGURA 5 - Exposição de um modelo de biomolécula encapsulada no hidrogel polimérico (Bayer e Peppas, 2008). 
A liberação de fármaco em um hidrogel depende das propriedades físico-químicas do gel, bem como das características estruturais do agente terapêutico. Três grandes abordagens para a liberação de droga podem ser resumidas como: difusão (diffusion), aprisionamento (entrapment) e aprisionamento por ligações covalentes ou físicas (tethering) (Tessmar, 2007; Dash, 2011), cada método tem suas vantagens e desvantagens. O método mais fácil para a liberação da droga é colocar o hidrogel totalmente formado em um meio saturado com o agente terapêutico (Dash, 2011; Sokker, 2009). A droga difunde-se lentamente no gel, dependendo da porosidade do hidrogel, do tamanho da droga, e das propriedades químicas de cada um como a hidrofobicidade/hidrofilicidade.

Quando colocado "in vivo", o medicamento difunde-se para fora do hidrogel no tecido com a lesão. Esta técnica tem provado ser eficaz no carregamento de moléculas pequenas, mas não no tratamento com peptídeos e proteínas, em particular, pois não são prontamente capazes de migrar através dos pequenos poros do hidrogel (Bhattarai, 2009). No entanto, este processo também consome muito tempo e não é recomendado para finalidades de fabricação.

Portanto, no caso de grandes dimensões e drogas bioligantes, é preferível ter o fármaco aprisionado durante o processo de gelificação. Geralmente, o fármaco é misturado em uma solução de polímero, e adicionado à qual agente reticulante e agente complexante. A química da molécula do fármaco deve impedir a reticulação considerada indesejada ou a desativação do agente terapêutico durante a gelificação, deixando livre o movimento do agente terapêutico para fora da rede do hidrogel. Esse processo que impede a reticulação do fármaco é usado tanto na difusão quanto no sistema de aprisionamento (Dash, 2011).

Para reduzir a perda da reserva terapêutica e o risco de exposição à substâncias tóxicas, a droga deve estar normalmente ligada covalentemente ou fisicamente à cadeias de polímero antes da gelificação. Esta técnica é denominada como amarramento por ligações físicas ou covalentes (tethering) e libera o agente somente quando o hidrogel rompe ou a ligação molecular é 
quebrada (Hoare, 2008). A liberação do fármaco pode tornar-se complicada por moléculas que têm características opostas ou carga semelhante como o polímero contida na matriz (Ruel-Gariepy, 2004). Uma alternativa, em tais casos, é formar um complexo com aditivos anfifílicos antes que o hidrogel e a droga sejam misturados em solução (Obara, 2005; Dash, 2011). Os agentes terapêuticos podem também ser liberados em pequenos veículos de liberações secundárias, tais como micropartículas, microgéis, lipossomas e micelas, antes do encapsulamento de hidrogel (Lee, 2004; Joung, 2007, Loutolf, 2005 ).

Várias pesquisas recentes têm reportado a investigação de hidrogéis poliméricos em nanoescala que demostram resultados terapêuticos para liberação de drogas tais como a insulina e outros agentes. Peppas e colaboradores estão desenvolvendo hidrogéis de biopolímeros para liberação transmucosa e intracelular para uso de quimioterápicos e agentes terapêuticos biológicos (Peppas, 2011).

Rosiak e colaboradores continuam investigando hidrogéis e nanogeis reticulados por várias técnicas, entre elas radiação ionizante e pulsos de elétrons, métodos de síntese que permitem obtenção de nanogéis desejados. Por essas técnicas elimina-se o uso de monômeros, agentes de ligações cruzadas, ou outras substâncias auxiliares, tornando-os adequados para usos biomédicos (Rosiak, 2012).

Segundo estudos de Hoffmam e colaboradores estão sendo investigadas as propriedades relevantes dos hidrogéis poliméricos para aplicações biomédicas, como uso em liberação de droga em tecidos biológicos de engenharia (Hoffmam, 2012). Já Lugão e colaboradores estão investigando hidrogéis para várias aplicações a partir de encapsulamento entre elas: liberação de hormônio, antioxidante, bactericida e liberação de enzimas (Lugão, 2010).

São encontrados diversos produtos em forma de hidrogéis no mercado nacional e internacional indicados para vários tratamentos de lesões e queimaduras, mas não são encontrados hidrogéis para tratamento de lesões provocadas por Leishmania, conforme é mostrado na TAB. 1. Segundo nosso 
conhecimento, também não são encontrados hidrogéis poliméricos com argila reticulados por radiação gama para uso biomédico, que é objeto de inovação do nosso trabalho.

TABELA 1 - Exemplo de produtos à base de hidrogéis poliméricos encontrados no mercado para tratamento de lesões.

\begin{tabular}{|c|c|c|c|}
\hline Nome & Produto & Fabricante & Tratamento \\
\hline $\begin{array}{l}\text { Normlgel } \\
\text { (hidrogéis com } \\
\text { cloreto de sódio } \\
0,9 \% \text { ) }\end{array}$ & & $\begin{array}{l}\text { Molmlucke Healt } \\
\text { Care }\end{array}$ & $\begin{array}{l}\text { Remoção de } \\
\text { crostas e } \\
\text { tecidos } \\
\text { desvitalizados }\end{array}$ \\
\hline $\begin{array}{l}\text { Dermasyn } \\
\text { hydrogel Wound } \\
\text { Filler (Com } \\
\text { vitamina A) }\end{array}$ & & $\begin{array}{l}\text { Dermarite } \\
\text { Industries } \\
\text { Dermasyn }\end{array}$ & $\begin{array}{l}\text { Curativos para } \\
\text { pequenas } \\
\text { queimaduras }\end{array}$ \\
\hline $\begin{array}{l}\text { DermaSyn/Ag® } \\
\text { Antimicrobial Silver } \\
\text { Hydrogel }\end{array}$ & & $\begin{array}{l}\text { DermaRite } \\
\text { Industries }\end{array}$ & $\begin{array}{l}\text { Curativo } \\
\text { primário } \\
\text { liberação } \\
\text { controlada de } \\
\text { prata iônica } \\
\text { antimicrobiano }\end{array}$ \\
\hline $\begin{array}{l}\text { Curatec Hidrogel } \\
\text { com Alginato- } 25 \mathrm{~g}\end{array}$ & & Curatec $\AA$ & $\begin{array}{l}\text { Curativo } \\
\text { primário } \\
\text { proteção para } \\
\text { ferimento, } \\
\text { impermeável a } \\
\text { bactérias }\end{array}$ \\
\hline $\begin{array}{l}\text { Bandagens } \\
\text { estéreis Hidrogel }\end{array}$ & 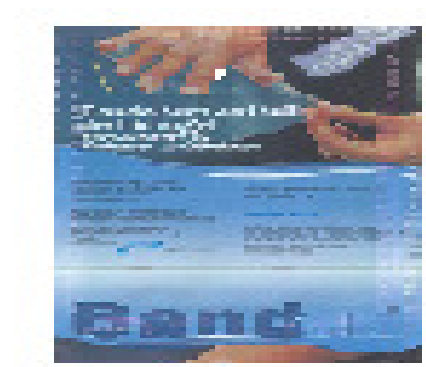 & $\begin{array}{l}\text { R \& D } \\
\text { Pesquisa \& } \\
\text { Desenvolvimento } \\
\text { IPEN | BIOLAB }\end{array}$ & $\begin{array}{l}\text { Curativos para } \\
\text { queimaduras }\end{array}$ \\
\hline
\end{tabular}




\subsection{Leishmaniose}

A Organização Mundial da Saúde (OMS) estima que 350 milhões de pessoas estejam expostas ao risco com registro aproximado de dois milhões de novos casos por ano, das diferentes formas clínicas. Classificam-se em quatro formas principais: leishmaniose visceral americana (LVA) ou calazar, a mais séria das formas sendo fatal caso não seja tratada; leishmaniose cutânea, a forma mais comum que causa lesões na pele; leishmaniose mucocutânea, que causa úlceras na pele e que pode levar à destruição de tecidos no nariz e boca e a leishmaniose cutânea difusa, que produz lesões crônicas na pele e assemelha-se à hanseníase. Estas três últimas formas de leishmaniose são atualmente classificadas como Leishmaniose Tegumentar Americana (LTA) ou úlcera de Bauru. A leishmaniose tegumentar tem ampla distribuição mundial, e no Continente Americano há registro de casos desde o extremo sul dos Estados Unidos até o norte da Argentina, com exceção do Chile e Uruguai (Manual de Vigilância L.T.A. 2007).

No Brasil, Moreira (1895) identificou, pela primeira vez, a existência do botão endêmico dos países quentes, chamando "Botão da Bahia" ou "Botão de Biskra" (Jacobina, 2008). A confirmação de formas de leishmania em úlceras cutâneas e nasobucofaríngeas ocorreram no ano de (1909), quando Lindenberg encontrou o parasita em indivíduos que trabalhavam em áreas de desmatamento na construção de rodovias no interior de São Paulo. Splendore (1911) diagnosticou a forma mucosa da doença e Gaspar Vianna deu ao parasita o nome de Leishmania braziliensis (Basano e Camargo, 2004).

No ano de 1922, Aragão, pela primeira vez, demonstrou o papel do flebotomíneo na transmissão da leishmaniose tegumentar e Forattini (1958), encontrou roedores silvestres parasitados em áreas florestais do Estado de São Paulo. Desde então, a transmissão da doença vem sendo descrita em vários municípios de todas as unidades federadas (UF). Nas últimas décadas, as análises epidemiológicas da leishmaniose tegumentar americana (LTA) têm sugerido mudanças no padrão de transmissão da doença, inicialmente considerada zoonose de animais silvestres, que acometia ocasionalmente pessoas em contato com as florestas. Posteriormente, a doença começou a 
ocorrer em zonas rurais, já praticamente desmatadas, em regiões periurbanas e nas periferias de grandes cidades. Observa-se que houve adaptação do vetor em regiões frias, e praticamente todas as regiões brasileiras apresentam focos de LTA (Gontijo e Carvalho, 2003).

\subsubsection{Vetores}

Os protozoários do gênero Leishmania sp. são heteroxenos que necessitam de dois tipos diferentes de hospedeiros para sua completa evolução: um vetor invertebrado e um hospedeiro definitivo. Os vetores invertebrados são dípteros da família Psychodidae, pertencentes ao gênero Phlebotomus (Velho Mundo) e Lutzomyia (Novo Mundo), com vasta distribuição nos climas quentes e temperados. Somente as fêmeas são hematófagas, FIG. 6, pois necessitam do sangue para o desenvolvimento dos ovos ao tipo dos dípteros de atividade crepuscular e pós-crepuscular, abrigando-se durante o dia em lugares úmidos, sombrios e bem protegidos dos ventos e são encontrados em tocas de animais silvestres. Os ovos são postos em locais cobertos pelo musgo. Na evolução, a larva madura fixa-se no subtrato e se transforma em pupa, mudando após mais alguns dias para adulto (FIOCRUZ, 2012), como apresenta a FIG. 6.

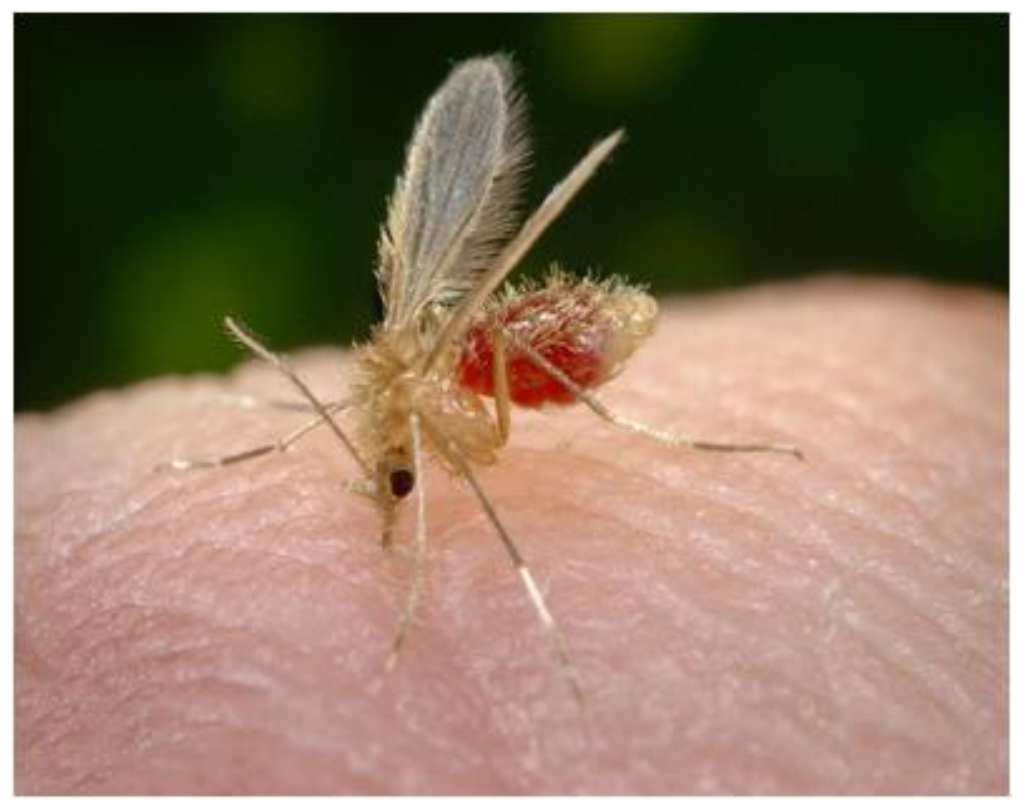

FIGURA 6 - Vetor fêmea alimentando-se de sangue e infectando o local da picada (FIOCRUZ, 2012). 
No Brasil, o inseto transmissor é conhecido por diferentes nomes, como mosquito palha, asa dura, cangalhinha, birigui, entre outros. Os hospedeiros como o cão e a raposa têm um papel preponderante na manutenção do parasita na natureza e são então chamados de reservatórios. No contexto epidemiológico, os reservatórios representam a principal fonte de infecção dos flebotomíneos que posteriormente transmitirão a doença ao homem (Biblioteca Virtual em Saúde, 2008).

O papel do cão como reservatório para a Leishmania foi enunciado pela primeira vez por Nicolle, em 1908, na Tunísia quando experimentalmente foi comprovada a infecção deste animal. Posteriormente, no mesmo país, foi comprovada a transmissão natural em cães e, assim, registrado o primeiro foco de leishmaniose visceral canina no mundo. No Brasil, as primeiras evidências de LVA foram constatadas em Abaeté (PA) como resultado dos trabalhos desenvolvidos por uma comissão instituída pelo Instituto Oswaldo Cruz (Rath, 2003).

O protozoário, em seu ciclo de desenvolvimento, FIG. 7 assume duas formas evolutivas: promastigota e amastigota. Os flebotomíneos, do gênero Lutzomyia e Psychopopygus, infectam-se ao picar o hospedeiro/reservatório ou um indivíduo contaminado aspirando macrófagos parasitados ou amastigotas livres no sangue ou tecidos e, podem, assim, transmitir a doença ao homem. Estudos parasitológicos da leishmania mostraram que a forma promastigota do parasita é flagelada e extracelular e vive no tubo intestinal do inseto e, esta forma promastigota é introduzida em mamíferos através da picada de fêmeas flebotomíneos. As formas promastigotas são rapidamente fagocitadas por células de defesa do sangue, conhecidas por macrófagos, e transformados na forma amastigota arredondada, sem flagelo no meio intracelular (Berman, 1988). 


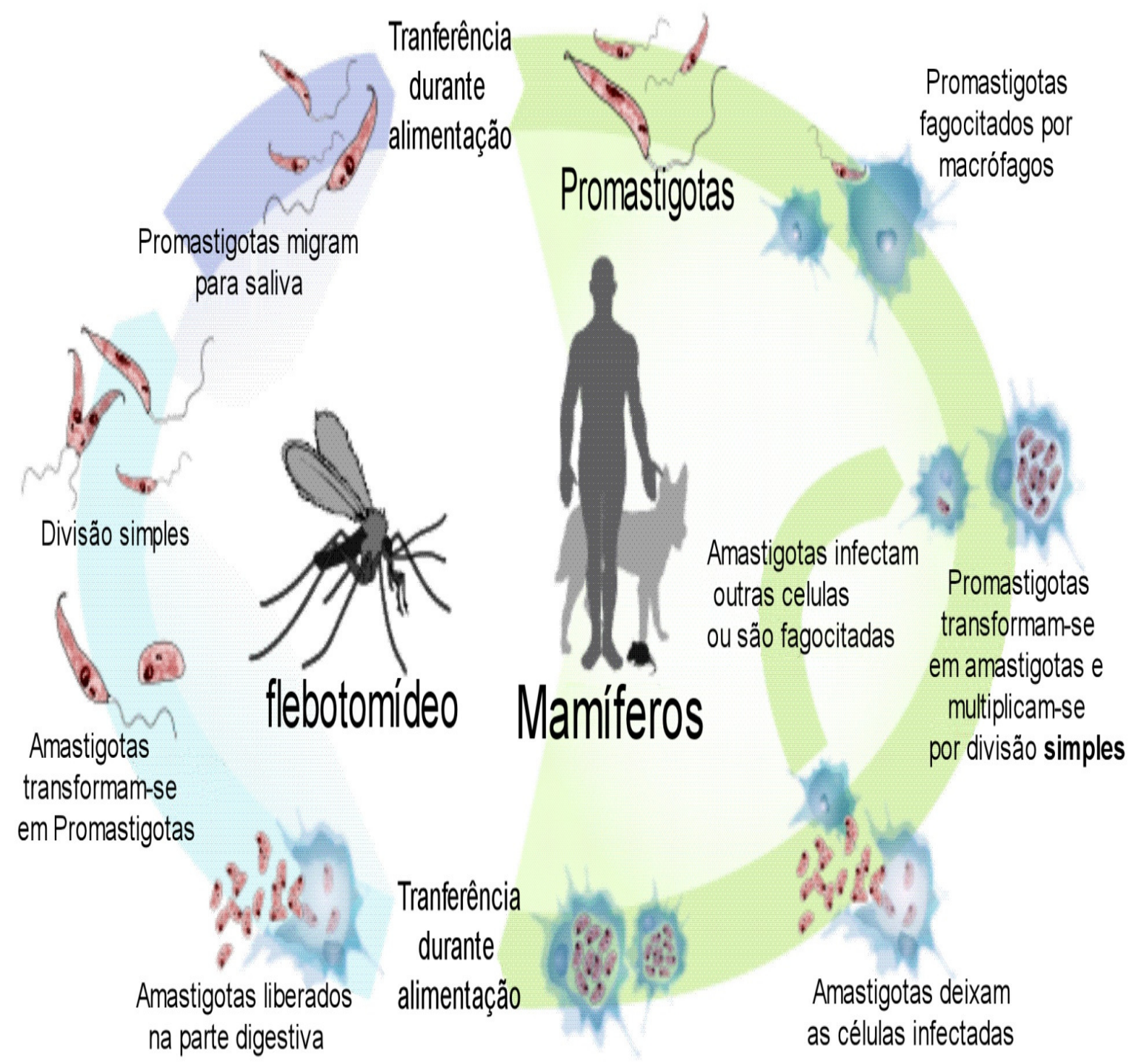

FIGURA 7- Ciclo da transmissão da leishmaniose a evolução nos reservatórios e nos vetores (http://parasitophilia.blogspot.com.br/).

\subsubsection{Profilaxia}

-Uso de repelente.

- Evitar a exposição nos horários das atividades dos vetores (crepúsculo e noite).

Usos de mosquiteiros, telas finas nas portas e janelas. 
Limpezas periódicas dos abrigos de animais domésticos.

Dedetização da região com proliferação do mosquito.

\subsubsection{Diagnóstico da doença}

O diagnóstico da leishmaniose é baseado nos exames clínicos dos sintomas que diferem para cada tipo de leishmaniose, nos dados epidemiológicos que devem levar em consideração as informações sobre a procedência do paciente e nos dados laboratoriais para que o diagnóstico seja confirmado (Amato, 2008).

O diagnóstico clínico é complexo, pois a doença no homem pode apresentar sinais e sintomas que são comuns a outras patologias presentes nas áreas onde incide a LTA. As características clínicas são semelhantes às hanseníases e úlceras abertas com difíceis cicatrizações em pacientes portadores de diabetes.

O diagnóstico laboratorial pode ser realizado por ensaios parasitológicos e imunológicos. No ensaio parasitológico, a verificação da presença do parasito pode ser feita em material de biópsia ou punção aspirativa do baço, fígado ou medula óssea, ou do ferimento, onde o material é examinado em lâminas coradas, inoculado em meios de cultura ou em animais experimentais de laboratório (Gontijo e Melo, 2004). A cultura deve ser realizada, a partir de fragmentos das bordas das lesões. Pelo exame histopatológico, visualizam-se amastigotas ou infiltrado inflamatório compatível.

\subsubsection{Tratamento da leishmania}

Apesar de apresentar grande prevalência mundial poucos avanços foram obtidos no tratamento das leishmanioses.

Em 1912, Gaspar Vianna introduziu o uso do tártaro emético, antimonial trivalente, no tratamento da leishmaniose. Porém, devido aos efeitos tóxicos e severos efeitos colaterais deste fármaco, os antimoniais foram 
substituídos pelos antimoniais pentavalentes, cujas estruturas químicas são mostradas na TAB. 2.

TABELA 2 - Estrutura química de antimoniais empregados na clínica médica para o tratamento das leishmanioses, com respectivos nomes químicos (Rath, 2003).

\begin{tabular}{|c|c|c|c|c|}
\hline Nome químico & \multicolumn{3}{|c|}{ Formula estrutural } & Nome comercial \\
\hline $\begin{array}{l}\text { Tartarato de } \\
\text { antimônio } \\
\text { e potássio }\end{array}$ & $\left\{\begin{array}{l}\mathrm{O} \\
\stackrel{I}{\mathrm{CO}}- \\
\mathrm{I}- \\
\mathrm{HCO}-\mathrm{Sb}-\mathrm{OH} \\
\mathrm{I} \mathrm{HO}- \\
\quad \\
\mathrm{COOH}\end{array}\right.$ & \multicolumn{2}{|c|}{$\mathrm{K}$} & $\begin{array}{l}\text { Tártaro emético } \\
\text { (trivalente) }\end{array}$ \\
\hline Ureia estibamina & \multicolumn{3}{|l|}{$\begin{array}{c}\mathrm{OH} \\
\mid \\
\mathrm{O}= \\
\mid\end{array}$} & $\begin{array}{l}\text { Estibamine } \\
\text { (pentavalente) }\end{array}$ \\
\hline $\begin{array}{l}\text { Gluconato de } \\
\text { antimônio (V) } \\
\text { sódico } \\
\text { ou } \\
\text { Estibogluconato } \\
\text { de } \\
\text { Sódio }\end{array}$ & \multicolumn{2}{|c|}{ 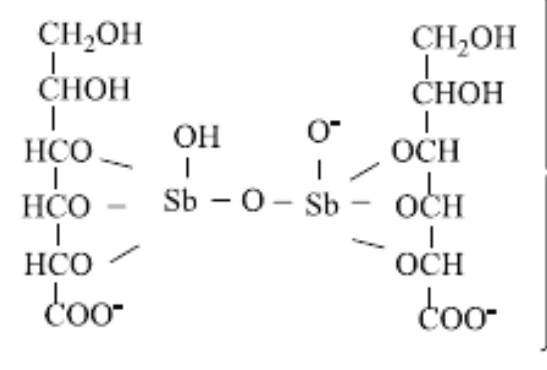 } & $\mathrm{Na}_{3} .9 \mathrm{H}_{2} \mathrm{O}$ & $\begin{array}{l}\text { Pentostam }^{\circledR} \\
\text { Solustibosan® } \\
\text { (pentavalente) }\end{array}$ \\
\hline $\begin{array}{l}\text { Antimoniato de N- } \\
\text { metilglucamina }\end{array}$ & \multicolumn{3}{|l|}{$\begin{array}{c}\mathrm{CH}_{2} \mathrm{NHCH}_{3}{ }^{+} \\
\mid \\
\mathrm{HCOH} \\
! \\
\mathrm{HOCH} \\
I \\
\mathrm{HCOH} \\
! \\
\mathrm{HCOH} \\
\text { I } \\
\mathrm{CH}_{2} \mathrm{OH}\end{array}$} & $\begin{array}{l}\text { Glucantime }^{\circledast} \\
\text { Antimoniato de } \\
\text { Meglumina } \\
\text { (pentavalente) }\end{array}$ \\
\hline
\end{tabular}

$\mathrm{Na}$ década de 20 do século passado, Bramachari desenvolveu o primeiro medicamento à base de antimônio pentavalente, a uréia estibamina. Em 
1936, Schmidt introduziu o gluconato de antimônio (V) sódico, conhecido comercialmente como Solustibosan ${ }^{\circledR}$ (Bayer) ou Pentostam ${ }^{\circledR}$ (Glaxo Wellcome) (Ministério da Saúde 2008).

Outro antimonial pentavalente foi desenvolvido durante a segunda guerra mundial, o antimoniato $\mathrm{N}$-metilglucamina que é comercializado atualmente como Glucantime $\AA$ ou antimoniato de meglumina. Enquanto o Pentostam $\AA$ é distribuído até hoje nos países de língua inglesa, o antimoniato de $\mathrm{N}$ metilglucamina, manufaturado originalmente pela Rhône-Poulenc-Rohrer na França, é comercializado nos países de línguas francesa e espanhola. No Brasil, o medicamento à base de antimônio utilizado no tratamento da leishmaniose é o fármaco comercializado pelo nome de Glucantime ${ }^{\circledR}$ ou antimoniato de meglumina (Ruth, 2003).

Além dos antimoniais, atualmente outros fármacos têm sido empregados no tratamento das diversas formas de leishmaniose, entre os quais se destacam a pentamidina, anfotericina B, paromomicina e miltefosine. Entretanto, não se tem disponível um fármaco que apresente um bom índice terapêutico associado a uma baixa toxicidade (Amato, 2008).

A anfotericina B é um antibiótico antifúngico utilizado como segunda escolha no tratamento de leishmaniose. Os efeitos colaterais deste fármaco são inúmeros, sendo uma das principais complicações a nefrotoxicidade. Uma nova formulação da anfotericina $B$, a anfotericina-B-lipossomal vem sendo indicada a pacientes graves de leishmaniose visceral que desenvolveram insuficiência renal ou toxicidade cardíaca durante $\mathrm{O}$ tratamento com antimoniato de $\mathrm{N}$ metilglucamina, porém a anfotericina-B-lipossomal apresenta um custo elevado (Amato, 1998).

A toxicidade dos antimoniatos é muito agressiva ao organismo, provocando arritmia cardíaca, disfunções renais, entre outros efeitos colaterais. $O$ uso do tratamento é de forma injetável, a dose do fármaco cai diretamente na corrente sanguínea. Se o paciente apresentar uma dessas disfunções não pode fazer uso do tratamento, ficando com o ferimento para o resto da vida, que pode 
durar um, cinco ou mais de dez anos, dependendo da resistência do organismo desse paciente. Durante o tratamento o paciente necessita de internação porque os efeitos colaterais ocorrem de diversas formas, incluindo disfunções renais e arritmia cardíaca.

$\mathrm{Na}$ maioria das vezes, as lesões cutâneas apresentam-se como uma lesão ulcerada única, com bordas elevadas em moldura, geralmente indolor, e fundo granuloso, com ou sem exsudação. As formas localizadas e disseminadas costumam responder bem à terapia tradicional. Na forma difusa, bem menos frequente, as lesões são papulosas ou nodulares, deformantes e muito graves, distribuindo-se amplamente na superfície corporal, podendo assemelhar-se à hanseníase Virchowiana. A forma difusa geralmente evolui mal, por não responder adequadamente à terapia tradicional.

O período de incubação da lesão cutânea de inoculação surge após um período de incubação médio de 30 dias, variando entre 15 dias e 6 meses.

O ferimento causado pela leishmaniose cutânea tem características diferentes dos ferimentos comuns provocados por fungos e bactérias, como representado na FIG. 8. Não pode ser usado tratamento tópico, como antibiótico ou anti-inflamatório, apenas lavagem com água.
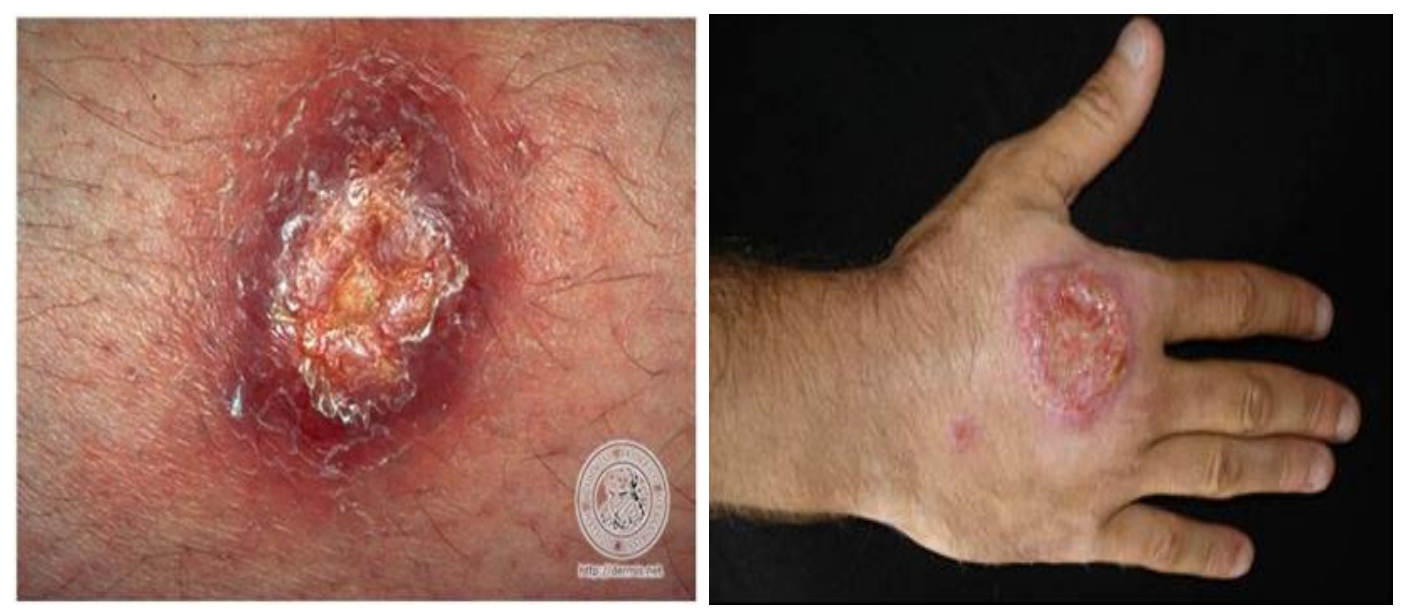

FIGURA 8 - Exemplo de lesões provocadas pela leishmaniose cutânea, (Vigilância Ambiental leishmaniose 2013). 


\subsection{Radiação lonizante}

As fontes de raios gama $(\gamma)$ mais comuns são os isótopos radioativos cobalto-60 e césio-137. O cobalto-60 é produzido artificialmente a partir do isótopo estável cobalto-59, em reatores nucleares, por captura neutrônica. Com uma semivida de 5,27 anos, o ${ }^{60}$ Co é o radioisótopo industrialmente mais utilizado. Este fato deve-se à maior intensidade energética das suas emissões gama (maior poder de penetração da radiação) relativamente ao ${ }^{137} \mathrm{Cs}$, e sua menor reatividade química (insolúvel em água) e consequente maior segurança radiológica em termos de armazenamento (Wojnárovits, 2003).

O decaimento radioativo do ${ }^{60} \mathrm{Co}$, esquematicamente representado na equação E1 ocorre por emissão de raios $(\gamma)$ originando o isótopo ${ }^{60} \mathrm{Ni}$. Este, por sua vez, decai para o estado fundamental, essencialmente por emissão de dois fótons com energias de 1,17 MeV e 1,33 MeV, respectivamente. A emissão de dois fótons gama por desintegração fornece uma energia total de $2,5 \mathrm{MeV}$ (Wojnárovits, 2003).

$$
{ }_{27}^{60} \mathrm{Co} \longrightarrow \beta^{-}+{ }_{28}^{60} \mathrm{Ni} \longrightarrow \boldsymbol{\gamma}+{ }_{28}^{60} \mathrm{Ni}
$$

A radiação ionizante constitui uma poderosa ferramenta para a modificação das propriedades dos materiais poliméricos. A sua elevada energia e capacidade de penetração na matéria originam uma grande variedade de estados excitados e íons, os quais podem dar sequência a reações químicas específicas (polimerização, reticulação, enxerto e degradação). O controle destas reações através da seleção adequada das espécies reagentes e das condições de irradiação constitui um conjunto de técnicas que permitem adequar as propriedades dos polímeros a aplicações específicas, como por exemplo, a síntese de novos materiais (De Paoli, 2008).

Os efeitos da radiação ionizante sobre polímeros em solução podem ser ligeiramente diferentes dos que ocorrem nos polímeros no estado sólido. Este fato deve-se que, em solução, a densidade eletrônica das moléculas poliméricas corresponde unicamente a uma pequena fração da densidade eletrônica total e 
como tal, o nível de excitação das moléculas diminui (para a mesma composição química, a dose de radiação absorvida é proporcional à densidade dos materiais). Por outro lado, a maioria dos primeiros produtos resultantes da radiólise provém do solvente e de outras espécies que possam estar presentes no meio, os quais, ao interferirem com o polímero, podem induzir a sua desativação prematura. Este processo pode acontecer através da ligação de pequenos fragmentos ou grupos funcionais aos centros ativos do polímero (Güven, 2007).

Esta ação indireta da radiação produz frequentemente algumas reorganizações estruturais, as quais não são consequência direta dos processos de cisão ou reticulação, como sucede com os polímeros irradiados no estado sólido.

De forma genérica, pode se dizer que os principais efeitos da radiação ionizante nos polímeros conduzem estas reações, que acompanham os processos de degradação ou reticulação das cadeias e podem ocorrer com velocidades e rendimentos muito variáveis. Taxas de dose muito elevadas tendem a aumentar e acelerar a fragmentação das longas cadeias poliméricas. A dose de radiação mais eficaz para um determinado processo depende da taxa de dose e do ambiente de irradiação (Chapiro, 1990; Chapiro, 2002).

A radiação ionizante em materiais orgânicos, geralmente contendo carbonos quaternários na cadeia principal, tende a degradá-los por reações de cisão, enquanto que os demais tendem a formar radicais facilitando as reações de reticulação.

O processo de polimerização via radical livre induzido por radiação ionizante envolve as etapas de iniciação equações 2 a 4, propagação equações 5 a 7 e terminação equações 8 e 9, segundo o esquema apresentado (Chapiro, 1990).

1) Iniciação.

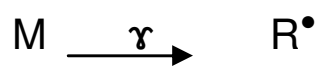


$\mathrm{S}\left(\mathrm{H}_{2} \mathrm{O}\right) \stackrel{\gamma}{\longrightarrow} \mathrm{OH}^{\bullet}, \bullet^{\bullet} \mathrm{H}_{2} \mathrm{O}_{2}, \mathrm{H}^{\bullet},{ }^{\bullet} \mathrm{HO}_{2}, \mathrm{H}_{2} \mathrm{O}_{2}, \mathrm{H}_{2} \mathrm{O}^{+}, \mathrm{e}^{-}$aq.

$\mathrm{S}^{\bullet}+\mathrm{M} \longrightarrow \mathrm{R}^{\bullet}$

2) Propagação

$\mathrm{R}^{\bullet}+\mathrm{M} \longrightarrow \mathrm{RM}^{\bullet}$

$\mathrm{RM}^{\bullet}+\mathrm{M} \longrightarrow \mathrm{RM}_{2}^{\bullet}$

$\mathrm{RM}_{\mathrm{n}-1} \cdot \mathrm{M} \longrightarrow \mathrm{RM}_{\mathrm{n}}^{\bullet}$

3) Terminação

$\mathrm{RM}_{\mathrm{n}}^{\bullet}+\mathrm{R}^{\bullet} \longrightarrow \mathrm{RM}_{\mathrm{n}} \mathrm{R}$

$\mathrm{RM}_{\mathrm{n}} \mathrm{R}^{\bullet}+\mathrm{T} \longrightarrow \mathrm{RM}_{\mathrm{n}} \mathrm{RM}+\mathrm{T}^{\bullet}$

onde:

$$
\begin{aligned}
& \mathrm{R}^{\bullet}=\text { radical livre de iniciação } \\
& \mathrm{M}=\text { monômero } \\
& \mathrm{RM}^{\bullet} \text { = cadeia intermediária propagando-se } \\
& \mathrm{n}=\text { equivale a números de repetição dos monômeros } \\
& \mathrm{T}=\text { inibidor (ou terminador) } \\
& \mathrm{T}^{\bullet}=\text { radical não propagador } \\
& \mathrm{S}=\text { Solvente aquoso }
\end{aligned}
$$

Um irradiador industrial consiste de uma sala com paredes de concreto, com dois metros de espessura, que contém a fonte de irradiação ( $\left.{ }^{60} \mathrm{Co}\right)$ (IAEA, 1992). Um sistema de esteiras transporta automaticamente o produto para dentro do ambiente de irradiação e promove a sua retirada após concluída essa operação. Quando existe a necessidade de manutenção na sala de irradiação, a 
fonte é recolhida ao fundo de uma piscina, cuja água absorve a energia da radiação, protegendo assim os operadores. A FIG. 9 ilustra as principais áreas de um irradiador industrial.

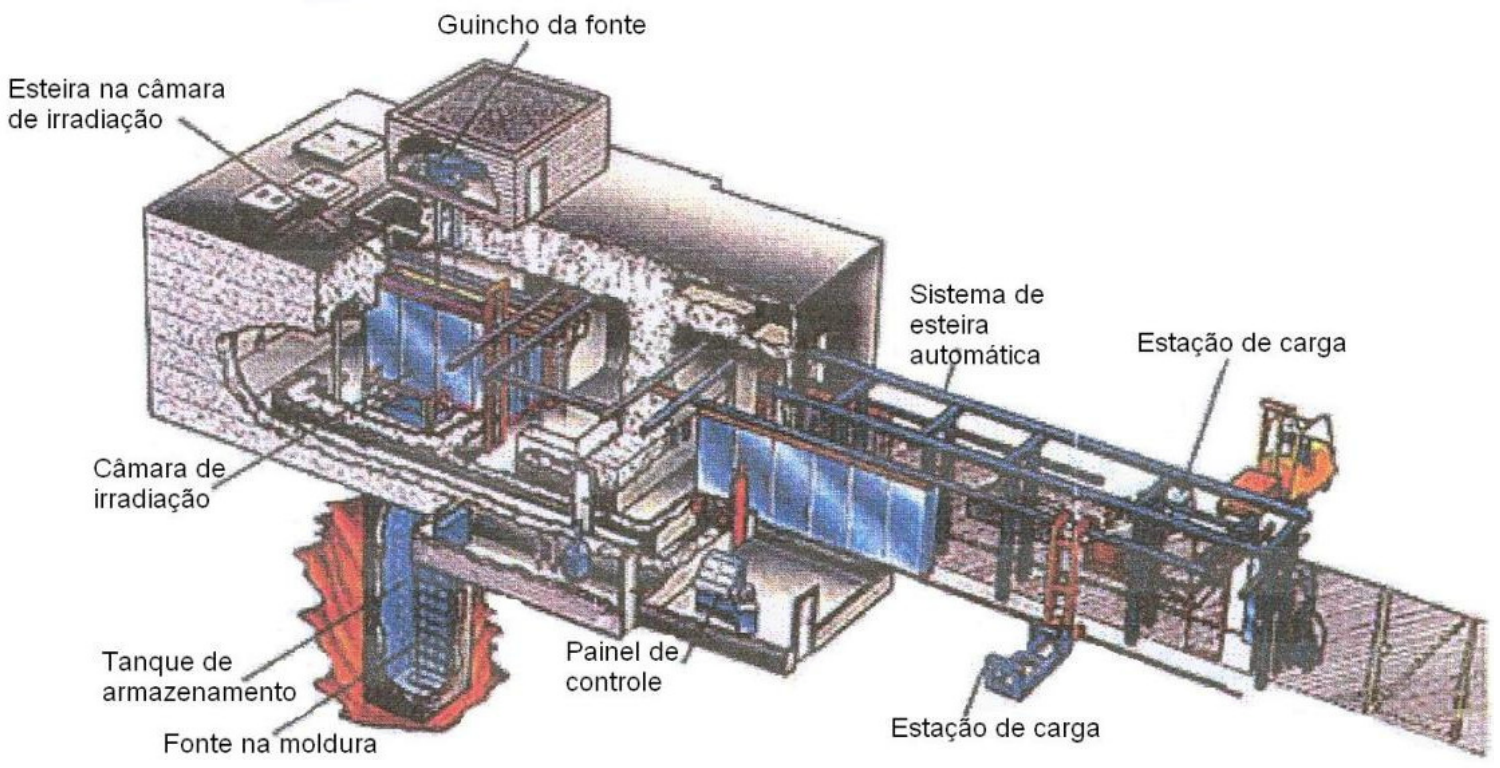

FIGURA 9 - Esquema representativo de uma unidade de radiação gama por ${ }^{60} \mathrm{Co}$ (IAEA, 1992).

\subsection{Poli (N-vinil-2-pirrolidona) (PVP)}

Poli(N-vinil-2-pirrolidona) também conhecido por polivinilpirrolidona PVP, é um homopolímero sintético que foi obtido por Reppe e colaboradores no início da $2^{\text {a }}$ Guerra a partir da polimerização da amida cíclica N-vinil-2-pirrolidona. $\mathrm{O}$ PVP é sintetizado por meio da polimerização em cadeia, geralmente via radical livre em soluções aquosas com iniciação química. O PVP é um pó branco, solúvel em água, altamente polar e que possui características anfóteras (Boletinho técnico K - 90). Estas características são indispensáveis em um hidrogel. A FIG. 10, apresenta o monômero de PVP. 


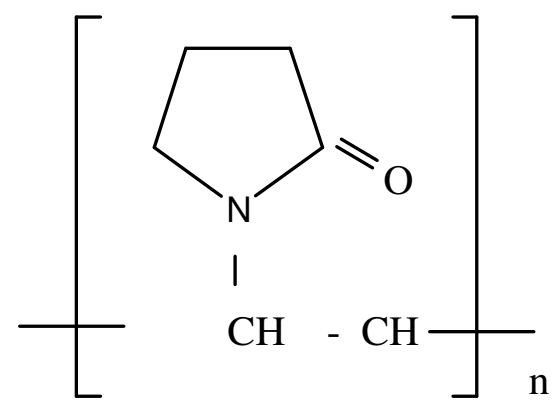

FIGURA 10 - Monômero Poli(N-vinil-2-pirrolidona) PVP

O PVP é utilizado em cosméticos devido a suas propriedades emulsivas de espessamento, por ser emoliente e solubilizante; em produtos têxteis aumentando a capacidade de tingimento em fibras hidrofóbicas; em bebidas fermentadas como clarificante; em produtos farmacêuticos como expansor do volume de plasma. Também é utilizado em sistemas liberadores de drogas atuando como retardante de absorção em medicamentos injetáveis (antibióticos e hormônios), curativos, aglutinantes em cápsulas, implantes de cartilagem, pele artificial, córnea artificial, lentes de contato e implantes cardiovasculares (Villanova, 2010).

O PVP em solução aquosa sob radiação ionizante sofre influência principalmente da ação dos radicais $\mathrm{OH}^{\bullet}$, sendo desprezível a influência dos $\mathrm{e}_{\text {(aq) }}^{-}$ (elétrons aquosos) e dos radicais $\mathrm{H}^{\bullet}$ (espécies produzidas na radiólise da água).

As estruturas prováveis dos macrorradicais de PVP obtidos pela abstração de hidrogênio pelos radicais hidroxílicos $\left(\mathrm{OH}^{\circ}\right)$ são mostradas na FIG. 11 .
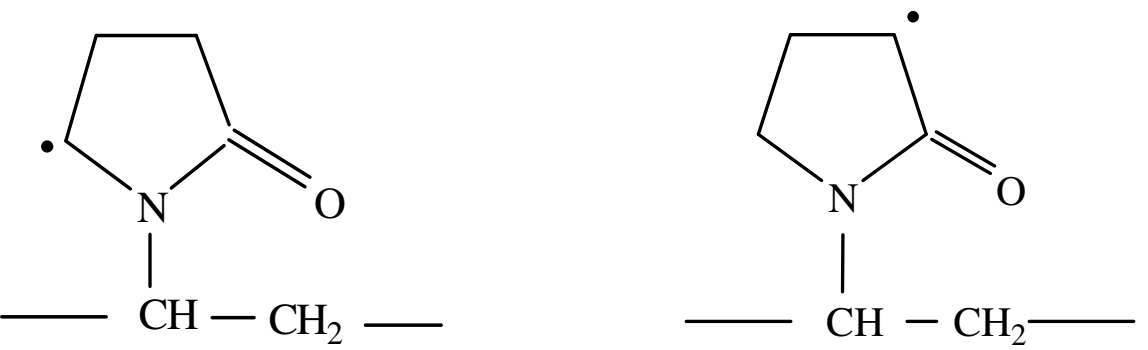

FIGURA 11 - Estrutura dos radicais de PVP produzidos por radiação ionizante. 


\subsection{Poli (álcool vinílico) (PVAl)}

A modificação química de polímeros é uma estratégia bastante utilizada para se obter polímeros com propriedades específicas para determinadas aplicações. Um exemplo clássico da modificação química de polímeros é o poli(álcool vinílico) (PVAl), que em razão da aplicação industrial é obtido com diferentes graus de hidrólise, o que depende da porcentagem dos grupos acetato do poli(acetato de vinila) (PVAc) (Hassan e Peppas, 2000), ilustrado na FIG. 12.<smiles>CC(C)(C)CC(I)CCC(=O)O</smiles>

$\mathrm{OCOCH}_{3}$

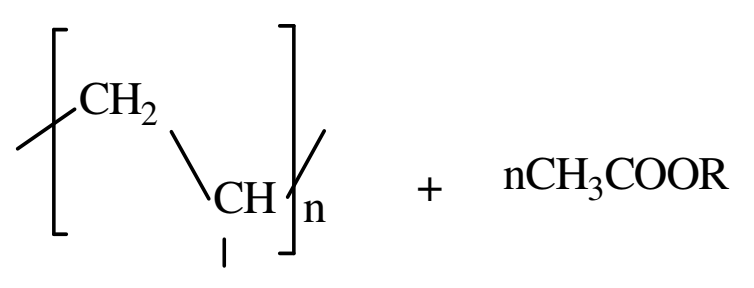

$\mathrm{OH}$

PVAc

PVAl

FIGURA 12 - Reação de alcoólise do PVAc em meio alcoólico/alcalino.

A estrutura molecular do PVAl é muito simples, com a unidade monomérica possuindo uma hidroxila como grupo pendente. O polímero é sintetizado a partir da alcoólise do poli(acetato de vinila) (PVAc). Devido ao equilíbrio tautomérico do álcool secundário o polímero não é isento de uma pequena quantidade de aldeído correspondente (Aranha, 2001), FIG. 13.
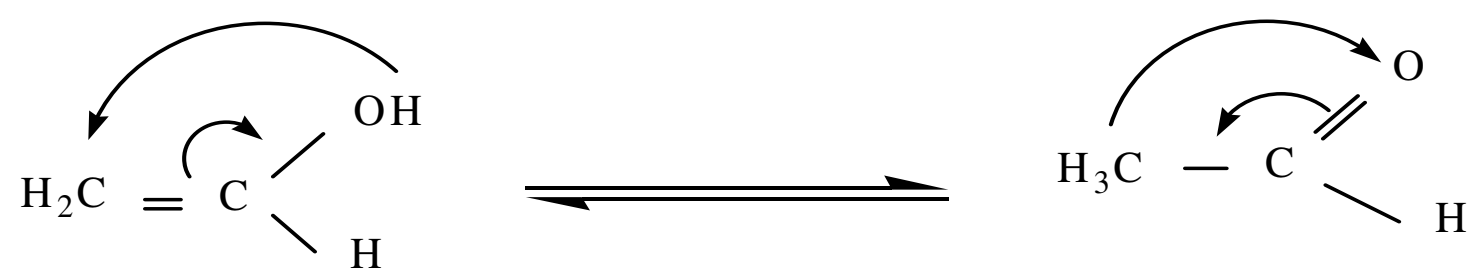

FIGURA 13 - Tautomeria entre o álcool vinílico e acetaldeído 
O grau de hidrólise afeta diretamente a solubilidade do PVAl em água, quanto maior o grau de hidrólise maior solubilização em água. No intervalo de grau de hidrólise de $85-95 \%$ a solubilização é possível de 20 a $40{ }^{\circ} \mathrm{C}$. Grupos acetatos residuais enfraquecem as ligações de hidrogênio intra e intermoleculares possibilitados por hidroxilas, nesse caso a temperatura de dissolução será acima de $70{ }^{\circ} \mathrm{C}$ (Mansur, 2008).

São encontrados na literatura vários estudos relacionados à investigação do efeito da radiação gama por ${ }^{60} \mathrm{Co}$ nas propriedades físicas do PVAl em fibras, hidrogéis e filmes irradiados em solução aquosa (Godovsky, 2000; Peppas e Marrille, 1976).

A obtenção de hidrogéis de PVAl reticulados por radiação gama e por processo físico, por congelamento e descongelamento, vem sendo analisados para aplicações farmacêuticas e biomédicas. Por serem isentos de subprodutos durante a reticulação, o que contribui com uma menor toxicidade do hidrogel considerando-se também a sua biocompatibilidade com tecidos vivos (Peppas, 2000).

\subsection{Quitosana}

A quitosana é um polímero obtido principalmente a partir da desacetilação alcalina da quitina, a qual é o segundo polímero natural mais abundante depois da celulose sendo encontrado nos exoesqueletos de artrópodes e alguns fungos. Possui propriedades interessantes para aplicação em engenharia de tecido, tais como biocompatibilidade e biodegradabilidade. Também acelera a recuperação de lesões, reduz o nível do colesterol sanguíneo, estimula os efeitos do sistema imunológico, além de ter se mostrado um composto bacteriostático e fungistático, bem como os resultados de sua degradação em organismos vivos que são as glicosaminas, substâncias não tóxicas (Mansur, 2008; Onuki, 2008).

Uma das características mais importantes deste polissacarídeo é o seu grau de desacetilação que representa a proporção de resíduos acetilados ainda 
presentes no mesmo, após o processamento para sua obtenção. A quitosana se degrada pela hidrólise enzimática e apresenta cinética de degradação aparentemente relacionada ao grau de cristalinidade que é controlado principalmente pelo grau de desacetilação (Suh, 2000). Entretanto, sua resistência mecânica e sua maleabilidade são limitadas principalmente para aplicação como filmes em bandagens. Por isso a mistura da quitosana com outros polímeros é um procedimento utilizado para alterar ou obter as propriedades de interesse. O grande desafio consiste em obter um material que resista, de forma controlada, à degradação em ambiente fisiológico.

A quitosana também tem sido investigada como suporte para a imobilização de enzimas, hidrogéis para liberação de fármacos e filmes para diversas aplicações. As quitosanas são produzidas à base de quitina e são encontradas na forma de pós, flocos ou géis de diferentes configurações geométricas.

Os pós e flocos de quitosana estão disponíveis como produtos comerciais da Sigma-Aldrich, Fluka, Polymar, entre outros. Quitosana em pastilha gel (quitopérolas) é produzida pela Fuji Spinning Co. Ltd. (Tóquio, Japão). Géis de quitosana são fáceis de fabricar pelo fato da mesma dissolver prontamente em soluções diluídas da maioria dos ácidos orgânicos, incluindo fórmico, acético, tartárico e ácidos cítricos, formando soluções viscosas, que se precipitam com o aumento do $\mathrm{pH}$ ou pela formação de complexos ionotrópicos insolúveis em água a partir da adição de polieletrólitos aniônicos. Desse modo, podem ser fabricados géis de quitosana na forma de membranas, matrizes, cápsulas, fibras e esponjas (Marconi, 1997; Campana e Signini, 2001). A FIG. 14 apresenta o monômero da quitosana. 


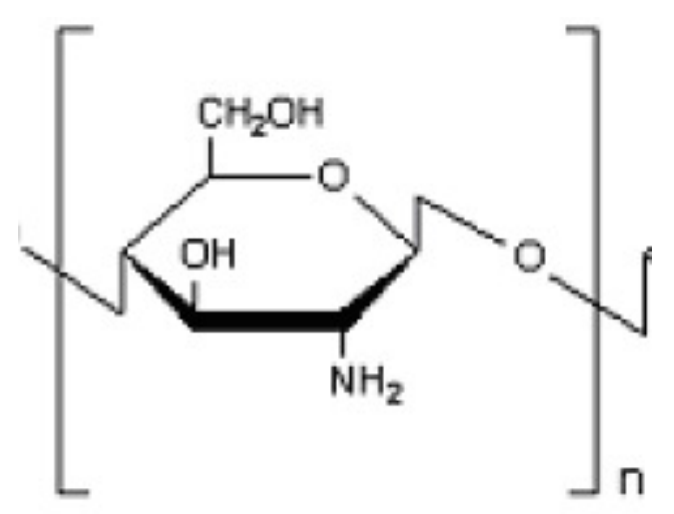

FIGURA 14 - Monômero da quitosana, (Revista Químicas e Derivados 2006).

\subsection{Argilas}

\subsubsection{Argilas naturais}

As argilas são aluminossilicatos em camadas, abundantes e baratos, que possuem propriedades adsorventes devido à sua grande área superficial e cargas negativas. Em geral, as espécies químicas podem interagir com as argilas por processos de troca iônica ou fisiosorção, sendo ambos os processos reversíveis (Mercier, 1995).

Algumas argilas são muito utilizadas na indústria de cerâmica. Seu cristal em formas de lâminas com habilidades para se unirem umas às outras quando aquecidas a altas temperaturas, as tornam aptas à fabricação de louças e tijolos. Também são utilizadas industrialmente como matéria-prima principal ou como componente acessório alternativo de uma grande lista de produtos tais como agentes absorventes, catalisadores, cerâmica artística, eliminação de resíduos radioativos, materiais porosos expandidos, agentes ligantes, tijolos, telhas e outros materiais de construção, cimentos, materiais cerâmicos para a indústria química, louça branca, cosméticos, clarificantes, agentes para descontaminação de água, fluídos para perfurador rotativo de poços, cargas ou enchimentos, produtos alimentícios, pesticidas, produtos medicinais e farmacêuticos, moldes e modelagens, tintas, abrasivos, sabões e detergentes, pós dentifrícios entre outros (Pergher, 2005; Takagi, 1993; Villemure, 1987). 


\subsubsection{Argilas especiais comercialmente raras}

São argilas das quais existem apenas um ou dois depósitos de dimensões que tornam rentável a comercialização das mesmas, em decorrência de suas propriedades tecnológicas valiosas como as hectorita, saponita e diquita.

O argilomineral esmectítico hectorita é a argila análoga a laponita usada neste trabalho, cuja fórmula da cela unitária cristalina é:

$$
\left[\left(\mathrm{Si}_{8} \mathrm{Mg}_{5.5} \mathrm{LiO}_{3}\right) \mathrm{O}_{20}(\mathrm{OH})_{4}\right]^{-0.7} \mathrm{M}^{+} \quad \text { onde } \mathrm{M}^{+} \text {é geralmente } \mathrm{Na}^{+}
$$

Uma argila constituída essencialmente por esse argilomineral esmectítico deveria ser chamada argila esmectítica ou então bentonita, se tivesse propriedades tecnológicas semelhantes às da bentonita do Estado de Wyoming, USA. Entretanto, a prática comercial também chama a argila de hectorita, portanto, o primeiro caso de argila especial rara é a "hectorita". Os depósitos estão em Hector, Califórnia, USA, e no Amargosa Valley, Nevada, USA (Coelho, 2007).

A hectorita sódica tem propriedades reológicas no sistema (argila + água) superiores às da bentonita sódica de Wyoming, além da cor branca das dispersões e géis. É usada em aerossóis, colas e adesivos, látex de borracha, clarificação de cervejas e vinhos, esmaltes cerâmicos, cosméticos e produtos para toalete, produtos de limpeza doméstica, tintas de emulsão e para eletro deposição, para revestimento de agregados e para fabricação de argilas organofílicas. Cerca de $2000 \mathrm{t}$ de hectoritas organofílicas são produzidas nos EUA por ano (Clarke, 1985).

\subsubsection{Hectorita sintética ou laponita}

Entre 1965 e 1970, as Indústrias Laporte desenvolveram e introduziram no mercado internacional uma hectorita sintética a partir de talco; o produto Laponita $B$ é considerado idêntico estruturalmente e também em propriedades tecnológicas à hectorita natural, além de ser livre de impurezas. 
As laponitas são vendidas pela metade do preço da hectorita lavada e seca por nebulização (Coelho, 2007). A composição química da laponita $R D$ está representada na TAB. 3, as propriedades físicas na TAB. 4, e a FIG. 15 apresenta a fórmula estrutural ideal da laponita e a FIG. 16 representa o compósito e nanocompósito polímero- argila (Zheng, 2005).

TABELA 3 - Composição química da argila laponita sintética (seca) (www.laponite.com).

\begin{tabular}{cc}
\hline Composição Química & $\%$ \\
\hline $\mathrm{SiO}_{2}$ & 59,5 \\
$\mathrm{MgO}$ & 27,5 \\
$\mathrm{Li}_{2} \mathrm{O}$ & 0,8 \\
$\mathrm{Na}_{2} \mathrm{O}$ & 2,8 \\
\hline
\end{tabular}

TABELA 4 - Propriedades físicas da laponita sintética (seca) (www.laponite.com).

\section{Propriedades Físicas}

\begin{tabular}{ll}
\hline Aparência & Pó branco \\
Densidade & $1000 \mathrm{~kg} / \mathrm{m}^{3}$ \\
Área de superfície & $370 \mathrm{~m}^{2} / \mathrm{g}$ \\
$\mathrm{pH}(2 \%$ suspensão) & 9,8 \\
Partícula & $100 \mathrm{~nm}$ \\
\hline
\end{tabular}




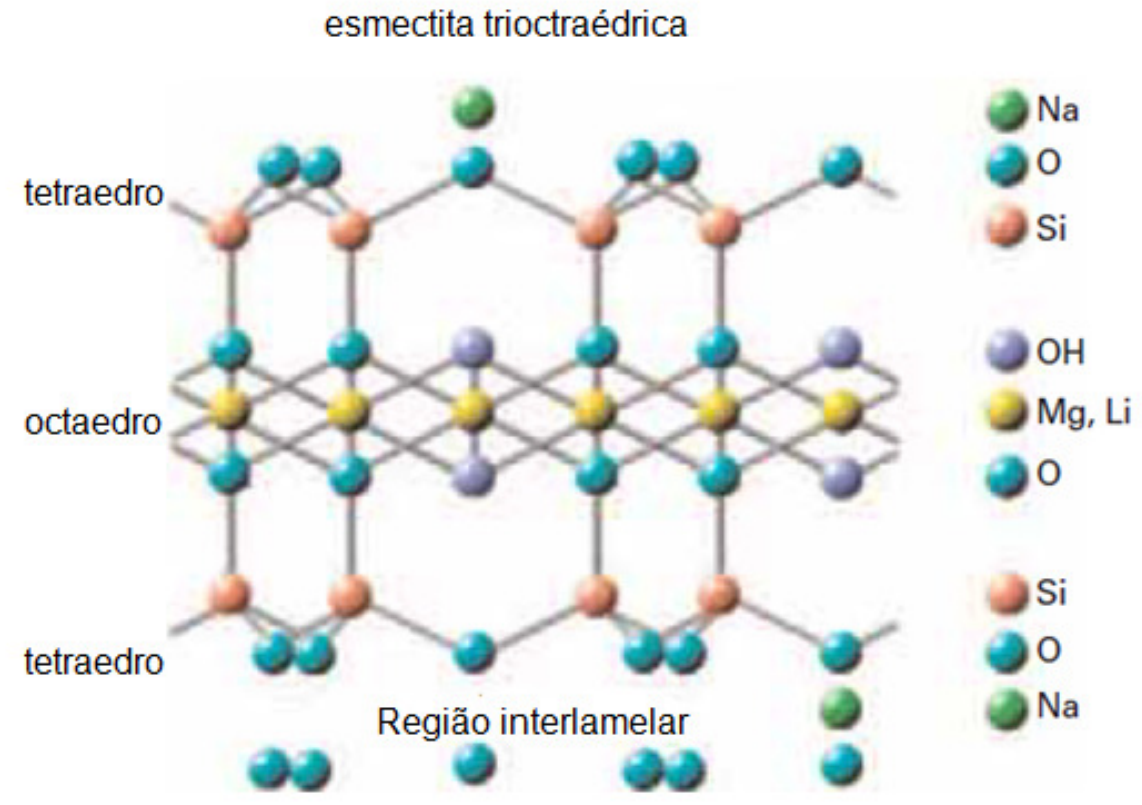

FIGURA 15 - Fórmula estrutural ideal da laponita RD (www.laponite.com).

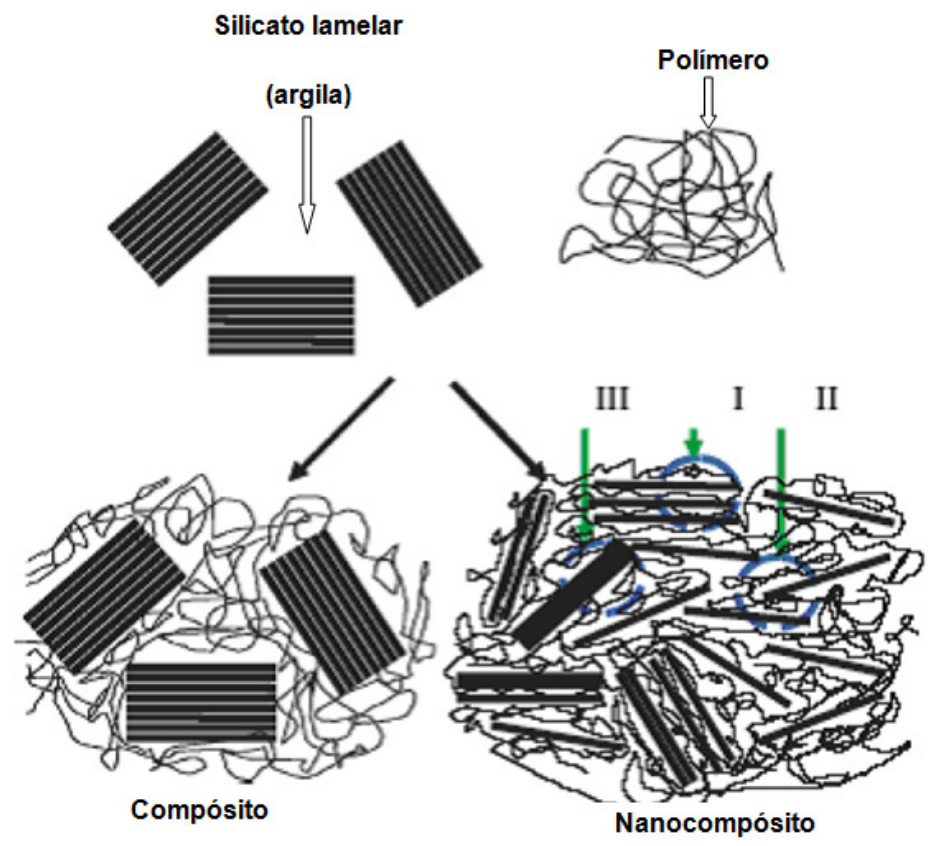

FIGURA 16 - Desenho esquemático de um compósito de polímero com argila mostrando a morfologia de um compósito convencional e de um nanocompósito com morfologia intercalada (I), esfoliada (II) e com aglomerados (III) (Zheng, 2005). 
Existem vários produtos farmacêuticos no mercado que incluem argilas como excipientes em suas formulações, por exemplo, Mebendazol, Bac-Sulfitrin, Pipurol®, Deltaflan, Calferon e Nimesulon. Há exemplos de patentes depositadas no Brasil protegendo a fabricação de medicamentos oftálmicos e adesivos dérmicos nos quais as argilas são aplicadas como carreadoras do princípio ativo (Teixeira-Neto, 2009).

É importante lembrar que existem alguns requisitos importantes para que uma argila seja usada em preparações farmacêuticas e cosméticas (LópezGalindo, 2007). Em especial destacam-se a granulometria, o grau de pureza mineral, a quantidade de água adsorvida, composição química e contaminação microbiológica. Dentre os filossilicatos, apenas a caulinita, o talco, as esmectitas hectoritas e as argilas fibrosas são utilizadas em aplicações farmacêuticas e/ou cosméticas. No caso de administrações tópicas, minerais como o talco e a caulinita podem carregar fármacos (antibióticos, analgésicos, anti-histamínicos), adsorvidos superficialmente, que são liberados quando em contato com a pele úmida (Carretero, 2002).

As argilas esmectitas possuem altas capacidades de troca catiônica e podem ser usadas para a intercalação de moléculas orgânicas com ou sem grupos polares (López-Galindo, 2007). As argilas modificadas são usadas para administração oral de fórmulas com liberação controlada. Algumas empresas comercializam esmectitas de grau farmacêutico como, por exemplo, as argilas Veegum ${ }^{\circledR}$ e a Polargel®, que passam por um processo de lavagem em água, (www.healthbeau-tysolutions.com).

\subsubsection{Glucantime fármaco usado para liberação}

Os medicamentos de primeira escolha utilizados para o tratamento das leishmanioses são complexos de antimônio pentavalente Sb (V), como o N-metil glucamina (Glucantime®) e o gluconato de sódio (Pentostam®). Esses fármacos são usados clinicamente por mais de meio século; seu mecanismo de ação permanece desconhecido e ainda não se sabe se a forma ativa dos antimoniais pentavalentes é o Sb (V) ou Sb (III) (Marsden, 1985). 
O antimonial N-metilglucamina apresenta-se comercialmente, em frasco de $5 \mathrm{ml}$, que contém $405 \mathrm{mg}$ do antimônio pentavalente (SbV) e cada $\mathrm{mL}$ contém $81 \mathrm{mg}$ de $\mathrm{Sb}(\mathrm{V})$. A composição como veículo é o metabissulfito de potássio, o sulfito de sódio e a água para injeção.

Para o tratamento das lesões cutâneas são geralmente recomendados $15 \mathrm{mg} \mathrm{Sb}(\mathrm{V})$ (antimoniato)/Kg/dia para o adulto (máximo 3 ampolas por dia) durante 20 dias consecutivos. O GLUCANTIME® é contraindicado em caso de hipersensibilidade ao antimoniato de meglumina e aos demais componentes do produto. É também contraindicado em caso de insuficiência renal, cardíaca ou hepática.

Farmacodinâmica: $O$ antimoniato de meglumina apresenta atividade leishmanicida. O mecanismo de ação preciso dos antimoniais pentavalentes permanece incerto. É pressuposto que várias enzimas da Leishmania spp sejam inibidas seletivamente. Esses agentes também parecem inibir a fosfofrutoquinase, com subsequente bloqueio da produção de adenosina trifosfato.

Farmacocinética: Mais de $80 \%$ da dose administrada é excretada dentro de 24 horas pela urina na forma inalterada e eliminada em duas fases: na primeira fase a meia-vida é pequena de aproximadamente de 2 horas, e na segunda fase, a meia-vida é mais lenta, cerca de 80 horas. A FIG. 17 apresenta a simulação da estrutura molecular do glucantime. Este fármaco à base de $\mathrm{Sb} \vee$ não possui estrutura química definida tendo sido relatados, entre outros, a presença de Sb III como contaminantes (www.bulas.med.br).

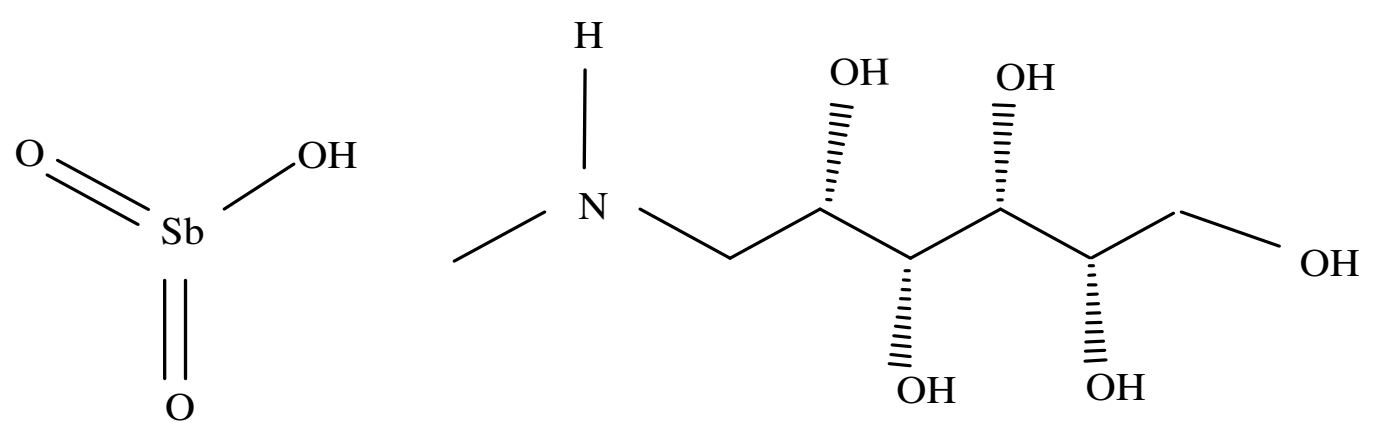

FIGURA 17 - Proposta molecular do glucantime (www.bulas.med.br). 


\subsubsection{Materiais e animais}

Segue uma lista abaixo, dos materiais e animais utilizados no trabalho e seus respectivos fornecedores:

- Poli(álcool vinílico) (PVAI) (Mw = 85000, grau de hidrólise 98,4\%) Celvol ${ }^{\mathrm{TM}} 325$ da Dermet Agekem.

- Poli(N-vinil-2-pirrolidona) (PVP) Kollidon 90 F da Basf.

- Poli(etilenoglicol) (PEG 300) fornecido pela Oxiteno.

- Quitosana da Fragon do Brasil Farmacêutico.

- Argila laponita RD código S/11176/10 fornecida pela Buntech.

- Glucantime (antimoniato de N-metilglucamina) fornecido pelo Dr. Valdir Sabbaga Amato, Laboratório de Investigação-Médica Parasitológica do HCFMUSP.

- Antimoniato de potássio Sb (V) da Vetec.

- Vermelho de pirogalol da Sigma.

>Solução tampão $(\mathrm{pH}=2)$ preparado com $0,2 \mathrm{~mol} \mathrm{~L}^{-1} \mathrm{KCl}$ e $0,2 \mathrm{~mol} \mathrm{~L}^{-1} \mathrm{HCl}$ da Synth.

-Ácido acético P.A. da Synth.

- Camundongos Balb/c machos fornecidos pelo Biotério da Faculdade de Medicina de São Paulo (USP).

- Água deionizada.

- Ágar fornecido da Oxoid. 


\subsubsection{Métodos}

\subsubsection{Preparo da solução para síntese das membranas}

Estão representados nos fluxogramas das FIG. 18, 19 e 20 as formulações para a síntese das membranas de hidrogéis e as respectivas concentrações estão indicadas nas TAB. 6, a 10. As formulações foram solubilizadas em água e homogeneizadas sob agitação. A pós as formulações prontas foram colocadas em placas, seladas e enviadas para a empresa onde foram reticuladas por radiação ionizante de fonte gama, assim obtendo-se os hidrogéis para os cincos sistemas estudas neste trabalho. O glucantime foi adicionado nas formulações antes da reticulação para a obtenção dos hidrogéis.

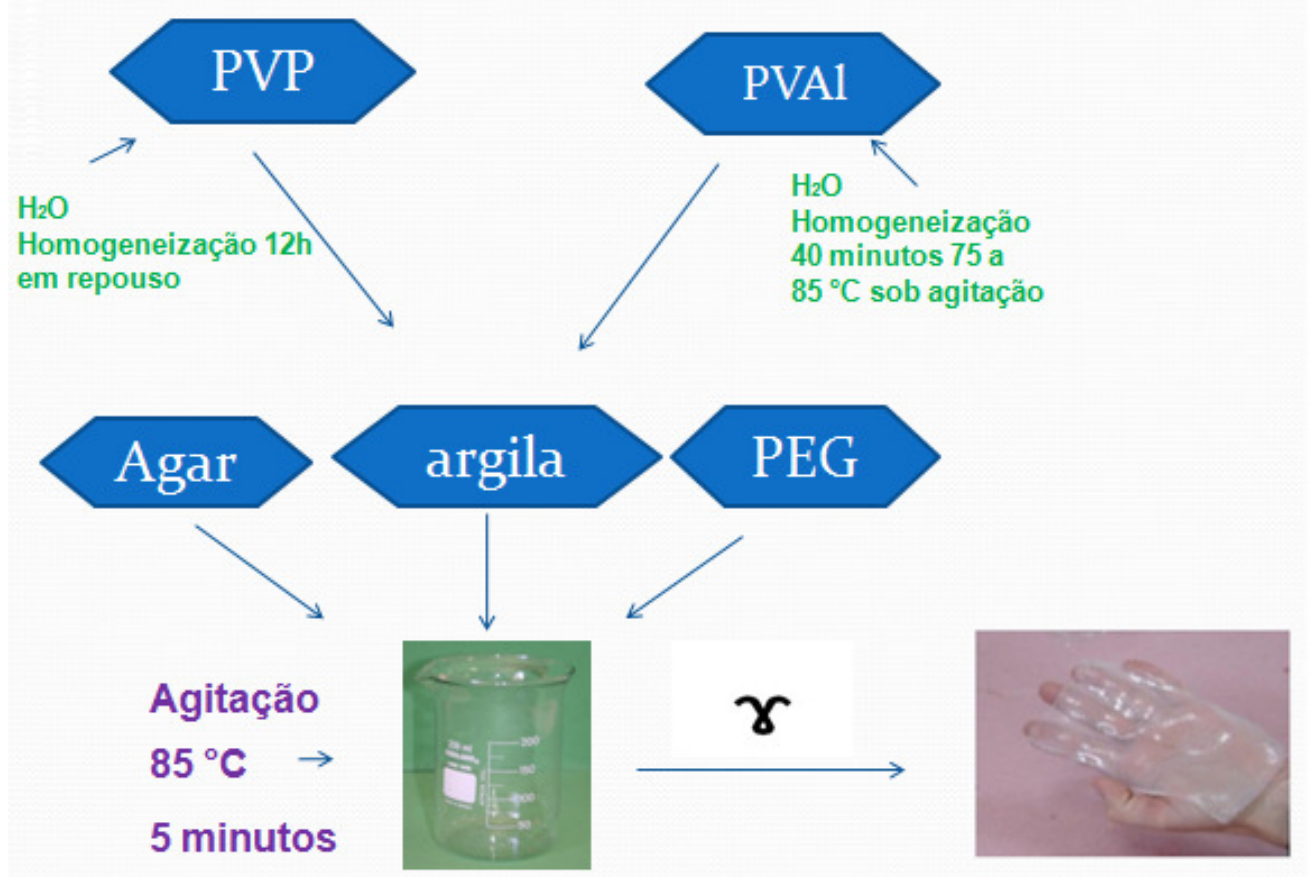

FIGURA 18 - Fluxograma das formulações para a obtenção da membrana para os sistemas PVAI/PVP/argila; PVAl/argila; PVP/argila.

Na FIG. 19 representa-se o fluxograma da formulação do sistema PVAl/quitosana/argila. 


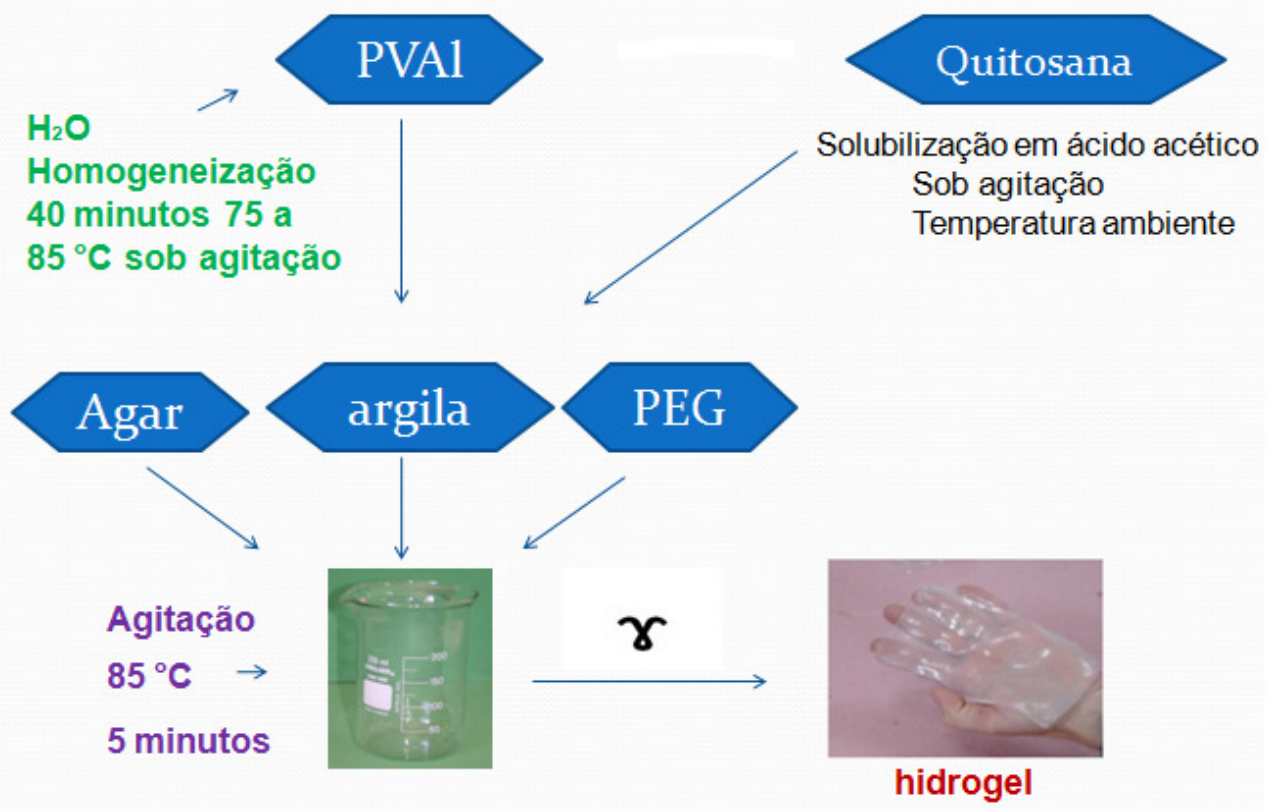

FIGURA 19 - Fluxograma da formulação para a obtenção da membrana para o sistema PVAl/quitosana/argila.

A FIG. 20 representa o fluxograma das formulações para o sistema de $\mathrm{PVP} /$ quitosana / argila.

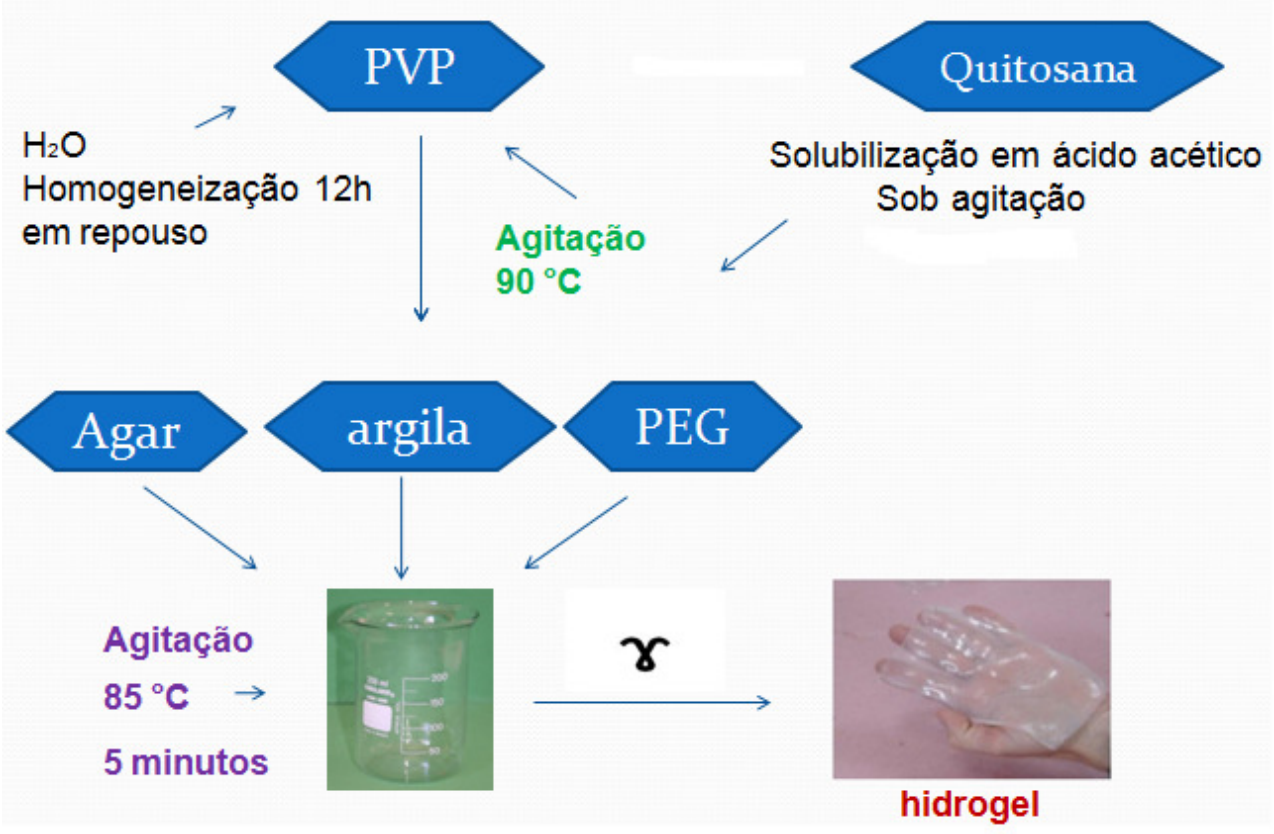

FIGURA 20 - Fluxograma da formulação para a obtenção da membrana para o sistema PVP/quitosana/argila. 
Estão representadas na TAB. 5 as concentrações para o sistema PVAI /PVA/argila.

TABELA 5 - Formulação PVAI/PVP/argila.

\begin{tabular}{cccc}
\hline & PVAl/PVP/0,5\%argila & PVAl/PVP/1,0\%argila & PVAl/PVP/1,5\%argila \\
\hline PVAl & 10,0 & 10,0 & 10,0 \\
PVP & 10,0 & 10,0 & 10,0 \\
Argila & 0,5 & 1,0 & 1,5 \\
Agar & 1,5 & 1,5 & 1,5 \\
PEG & 1,0 & 1,0 & 1,0 \\
Água & 77,0 & 76,5 & 76,0 \\
\hline
\end{tabular}

Estão representadas na TAB. 6 as concentrações do sistema PVAl/argila.

TABELA 6 - Formulação PVAl/argila.

\begin{tabular}{cccc}
\hline & PVAl/0,5\%argila & PVAl/1,0\%argila & PVAl/1,5\%argila \\
PVAl & 10,0 & 10,0 & 10,0 \\
Argila & 0,5 & 1,0 & 1,5 \\
Agar & 1,5 & 1,5 & 1,5 \\
PEG & 1,0 & 1,0 & 1,0 \\
Água & 87,0 & 86,5 & 86,0 \\
\hline
\end{tabular}


A TAB. 7 apresenta as concentrações da formulação do sistema PVP/ argila.

TABELA 7 - Formulação PVP/argila.

\begin{tabular}{cccc}
\hline & PVP/0,5\%argila & PVP/1,0\%argila & PVP/1,5\%argila \\
\hline PVP & 10,0 & 10,0 & 10,0 \\
Argila & 0,5 & 1,0 & 1,5 \\
Agar & 1,5 & 1,5 & 1,5 \\
PEG & 1,0 & 1,0 & 1,0 \\
Água & 87,0 & 86,5 & 86,0 \\
\hline
\end{tabular}

As concentrações do sistema PVAl/quitosana/argila estão representadas na TAB. 8

TABELA 8 - Formulação PVAl/quitosana/argila.

\begin{tabular}{cccc}
\hline & $\begin{array}{c}\text { PVAl/quitosana/ } \\
0,5 \% \text { argila }\end{array}$ & $\begin{array}{c}\text { PVAl/quitosana/ } \\
1,0 \% \text { argila }\end{array}$ & $\begin{array}{c}\text { PVAl/quitosana/ } \\
1,5 \% \text { argila }\end{array}$ \\
\hline PVAl & 10,0 & 10,0 & 10,0 \\
Quitosana & 0,5 & 0,5 & 0,5 \\
Argila & 0,5 & 1,0 & 1,5 \\
Agar & 1,5 & 1,5 & 1,5 \\
PEG & 1,0 & 1,0 & 1,0 \\
Água & 86,5 & 86,0 & 85,5 \\
\hline
\end{tabular}


Estão representadas na TAB. 9 as concentrações do sistema PVP/quitosana/argila.

TABELA 9 - Formulação PVP/quitosana/argila.

\begin{tabular}{cccc}
\hline & $\begin{array}{c}\text { PVP/quitosana/ } \\
0,5 \% \text { argila }\end{array}$ & $\begin{array}{c}\text { PVP/quitosana/ } \\
1,0 \% \text { argila }\end{array}$ & $\begin{array}{c}\text { PVP/quitosana/ } \\
1,5 \% \text { argila }\end{array}$ \\
\hline PVP & 10,0 & 10,0 & 10,0 \\
Quitosana & 0,5 & 0,5 & 0,5 \\
Argila & 0,5 & 1,0 & 1,5 \\
Agar & 1,5 & 1,5 & 1,5 \\
PEG & 1,0 & 1,0 & 1,0 \\
Água & 86,5 & 86,0 & 85,6 \\
\hline
\end{tabular}

Após a caracterização das membranas de hidrogéis foram selecionadas as membranas sintetizadas com 1,5\% de argila para investigação da liberação do glucantime. O critério da escolha foi em decorrência das primeiras membranas de PVAI/PVP/1,5\% de argila apresentarem melhores características físico-químicas em relação as outras concentrações da argila.

Com o desenvolvimento do projeto, foi mantida essa formulação de $1,5 \%$ de argila para investigar a liberação do glucantime nos outros sistemas. 0 glucantime foi adicionado nas formulações com 1,5\% de argila nos hidrogéis usados para o tratamento dos animais, para a liberação "in vitro" e para o EDS após a solubilização de todos os reagentes e antes da reticulação. Na primeira sequência de membranas de hidrogéis foram adicionados $57,5 \mu \mathrm{L}$ de glucantime para $200 \mathrm{~mL}$ de formulação. Por ser um tratamento cutâneo com liberação controlada surgiu a necessidade de aumentar a concentração do fármaco para viabilizar a eficiência do tratamento, na segunda sequência foram adicionados $171,5 \mu \mathrm{L}$ de glucantime para $200 \mathrm{~mL}$ de formulação. 
Foi analisada a concentração do glucantime irradiado e comparada com a concentração do glucantime sem ser irradiado, para verificar se houve perda do princípio ativo antimônio do fármaco. Essa análise foi realizada pelo espectrofotômetro no UV - visível monitorando-se em $\lambda=510 \mathrm{~nm}$.

\subsubsection{Reticulação por radiação ionizante}

A reticulação por radiação ionizante foi usada para obtenção de hidrogéis a partir de PVAl, PVP, quitosana e argila. A irradiação foi realizada em fonte de ${ }^{60} \mathrm{Co}$, modelo 220 da inst. Eng. Atomic-Canada, de geometria circular, operando a 5,72 $\mathrm{kGy} \mathrm{h}^{-1}$ Localizada na Empresa EMBRARAD/CBE.

\subsection{CARACTERIZAÇÕES DOS HIDROGÉIS}

\subsubsection{Intumescimento}

Após a síntese, as amostras de hidrogéis foram secadas em estufa a $50{ }^{\circ} \mathrm{C}$ até obter massa constante. Em seguida foram imersas em água destilada e pesadas em intervalos de tempo até um período total de $60 \mathrm{~h}$ para a determinação do grau de intumescimento (ou inchamento). O resultado foi obtido usando-se a equação $A$, de acordo com a norma (ASTM D 570).

$$
\text { Intumescimento }(\%)=\left[\left(\mathrm{m}_{\mathrm{s}}-\mathrm{m}_{\mathrm{d}}\right) / \mathrm{m}_{\mathrm{d}}\right] \times 100
$$

cuja unidade é $\left(\mathrm{g} \mathrm{H}_{2} \mathrm{O} . \mathrm{g}^{-1}\right)$ sendo que $\mathrm{m}_{\mathrm{s}}$ é a massa do polímero intumescido e $\mathrm{m}_{\mathrm{d}}$ a massa do polímero seco.

\subsubsection{Fração gel}

A determinação de fração do gel foi obtida a partir das amostras secas, as quais foram pesadas e colocadas em gaiolas de aço inox (500 mesh) e imersas em água fervendo dentro de balões acoplados ao destilador de refluxo por um período de $12 \mathrm{~h}$, FIG. 20. A amostra extraída foi secada em estufa a $50{ }^{\circ} \mathrm{C}$ até se 
obter massa constante. A fração gel do material é calculada pela equação $B$, sendo o sistema adaptado à norma (ASTM D 2765). A fração gel indica a parte insolúvel, cujo valor é atribuído à fração polimérica reticulada.

$$
\text { Fração gel }(\%)=\left[\left(m_{\mathrm{f}}-\mathrm{m}_{\mathrm{i}}\right) / \mathrm{m}_{\mathrm{i}}\right] \times 100
$$

sendo que $m_{i}$ é a massa da amostra seca antes da extração e $m_{f}$ a massa final da amostra após a extração e secagem.

O sistema de balões acoplados utilizado para extração do gel está ilustrado na FIG. 21.

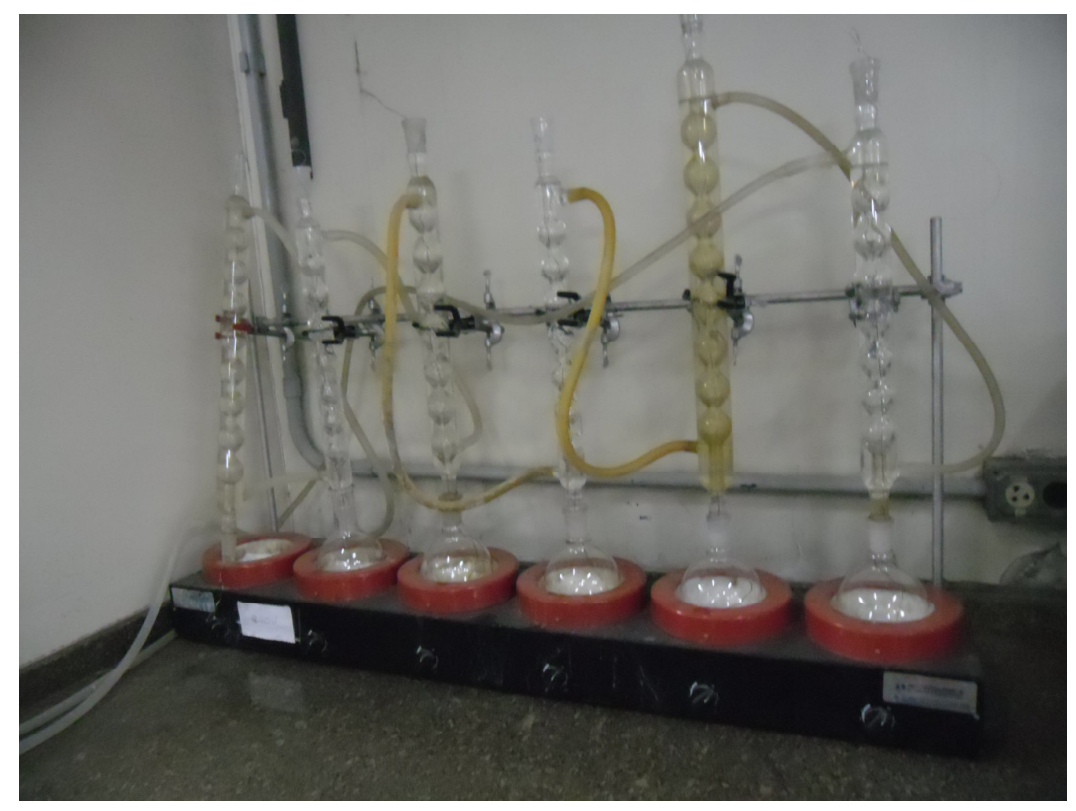

FIGURA 21- Sistema com balões acoplados para extração de fração gel.

\subsubsection{Termogravimetria (TG)}

As matrizes de hidrogéis secos por liofilização foram submetidas a ensaios de caracterização térmica a partir de análise de termogravimetria de TG/DTG em aparelho Mettler-Toledo SDTA $/ 851^{\mathrm{e}}$ (taxa de aquecimento: $10 \stackrel{\circ}{\circ}$ $\mathrm{min}^{-1}$, de 25 a $600{ }^{\circ} \mathrm{C}$, sob fluxo de $\mathrm{N}_{2}$ a $10 \mathrm{~mL} \mathrm{~min}^{-1}$ ) FIG. 22. Foram registradas as variações de temperaturas de início e final da decomposição. 


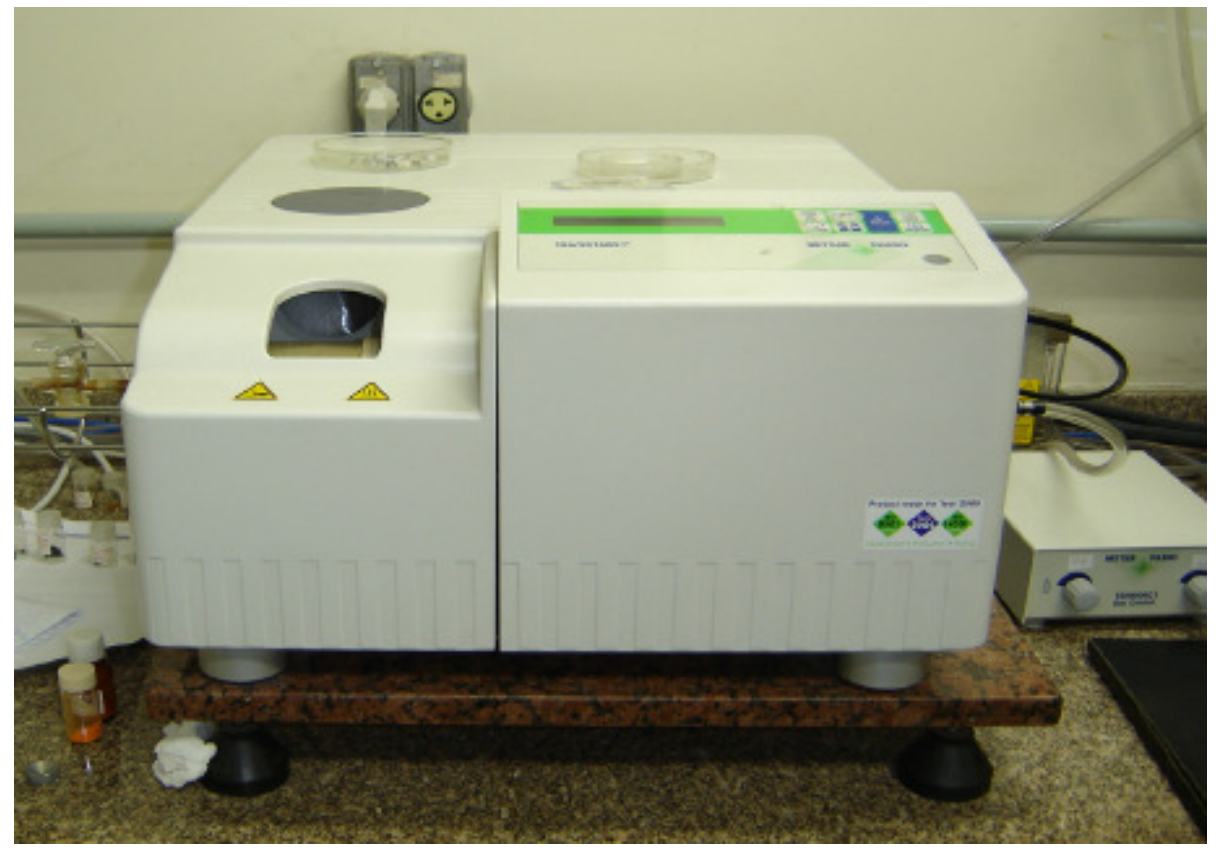

FIGURA 22 - Imagem do aparelho de análise de termogravimetria (TG)

\subsubsection{Espectroscopia no Infravermelho (FTIR)}

Os espectros de absorção de espectroscopia vibracional na região do infravermelho por transformada de Fourier foram obtidos utilizando-se a técnica de refletância total atenuada (ATR). Foram registrados na faixa do espectral de 4.000 a $400 \mathrm{~cm}^{-1}$ em espectrofotômetro Thermo Nicolet FTIR-OMNIC Modelo MB100 do Centro de Química e Meio Ambiente (CQMA) IPEN-CNEN/SP, FIG. 23. Teve como objetivo avaliar as bandas de absorção referentes às ligações moleculares. 


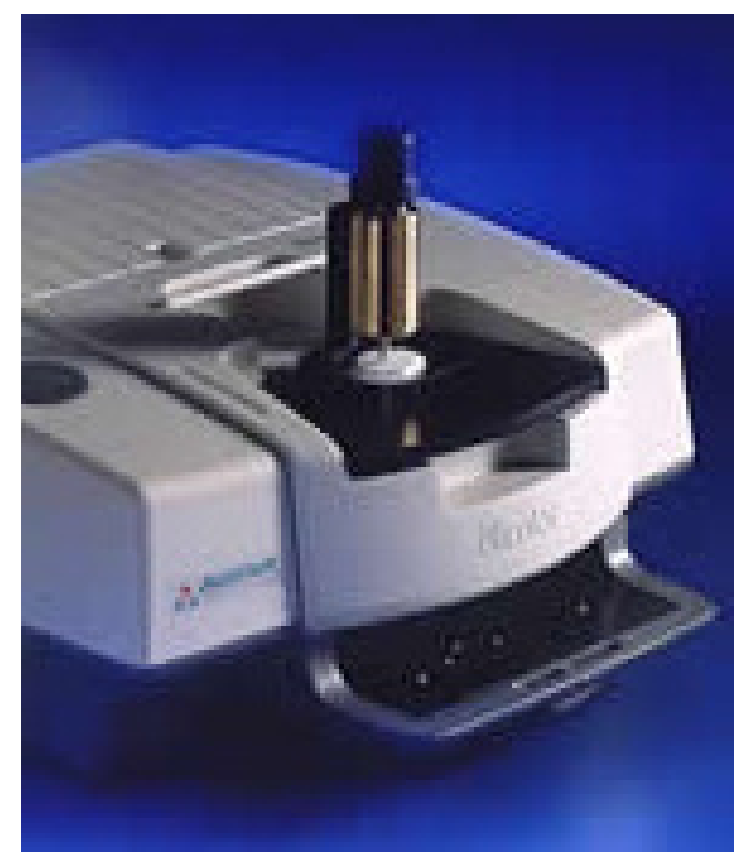

FIGURA 23 - Imagem do aparelho de Espectroscopia (FTIR).

\subsubsection{Difração de Raios X}

Essa análise teve como o objetivo avaliar a intercalação ou esfoliação da argila no nanocompósito polimérico usando-se filmes mediante o emprego de difratômetro de raios X, marca PANalytical, modelo X'Pert PRO com detector X'Celerator. Os parâmetros de análises foram: fonte geradora de raios $\mathrm{X}$ de $\mathrm{Cu}$,

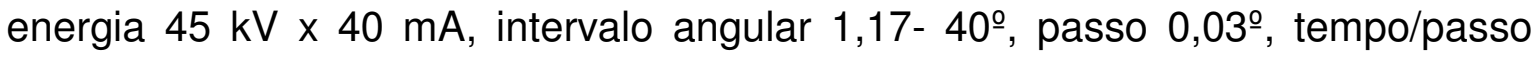
100ms. A FIG. 24 mostra o aparelho de DRX utilizado para a realização das análises.

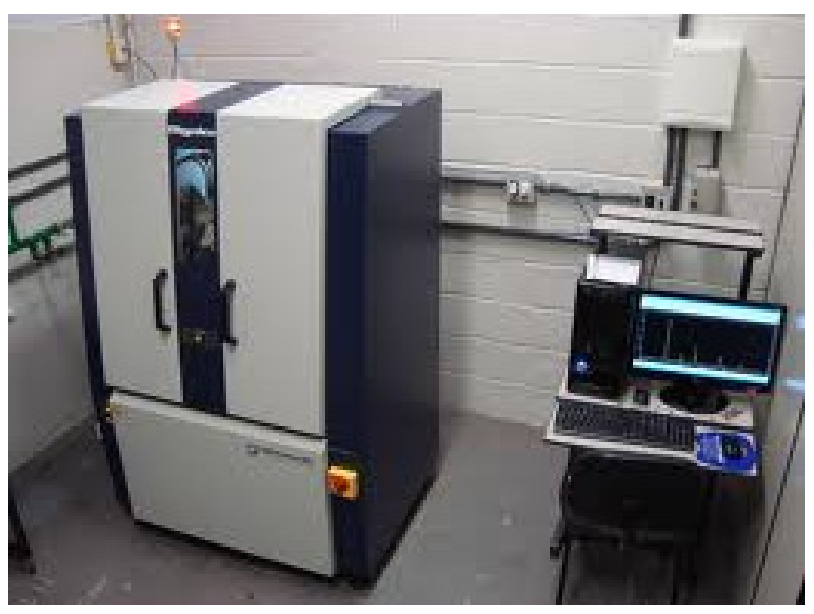

FIGURA 24 - Imagem do aparelho difratômetro de raios X. 
O espaçamento interplanar basal " $d$ " das estruturas argilominerais foram determinados pela Lei de Bragg, de acordo com a equação: $\Lambda=2 d$ sen $\theta$, onde:

$\mathrm{n}=$ um número inteiro;

$\Lambda$ = comprimento de onda da radiação incidente;

d = a distância ou espaçamento para o conjunto de planos "hkl" (índice de Miller) da estrutura cristalina;

$\Theta$ = ângulo de incidência de raios $X$ (medindo entre o feixe incidente e o plano cristalino).

A FIG. 25 apresenta os diferentes estados de dispersão da argila em relação ao polímero pela caracterização de DRX.

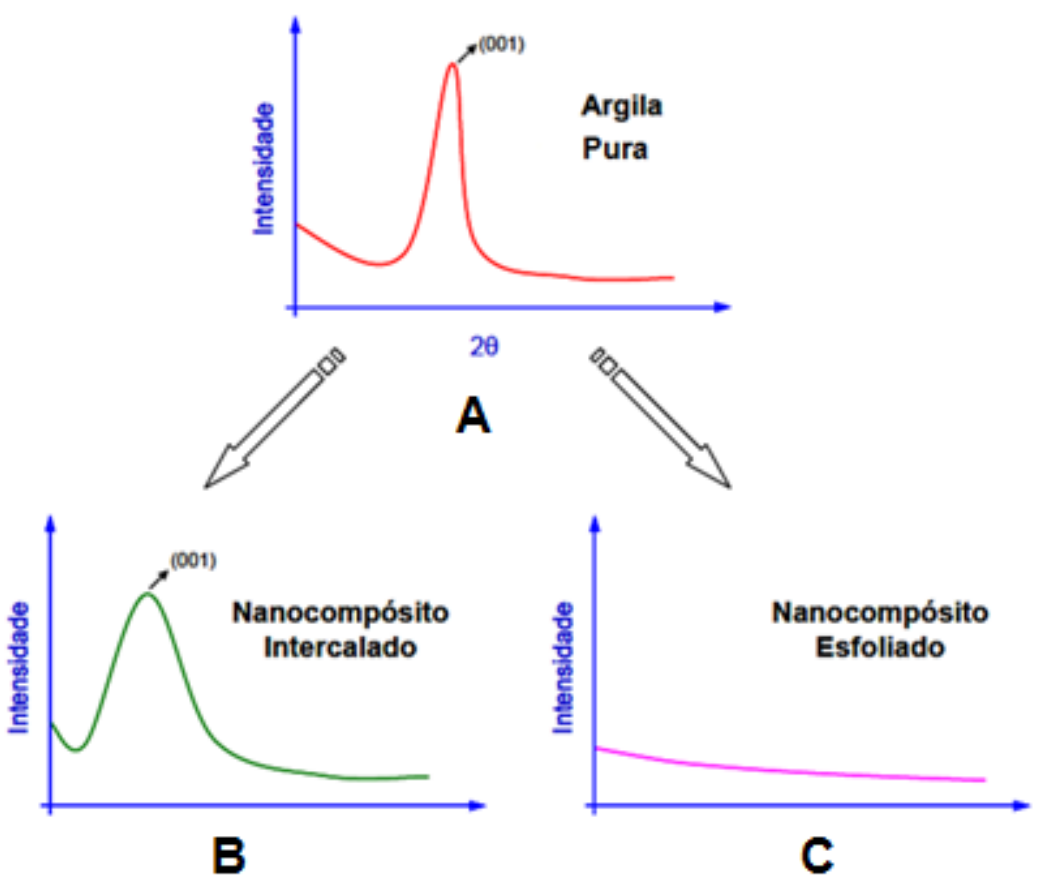

FIGURA 25- As diferentes representações da dispersão da argila em relação ao polímero pela análise de $\operatorname{DRX}(A)$ só a argila $(B)$ argila intercalada em relação ao polímero e (C) argila esfoliada em relação ao polímero. 
Pela análise do pico referente ao plano $\mathrm{d}_{001}$ da argila pode-se observar e analisar a estrutura do nanocompósito, ou seja, o estado da dispersão da argila em relação à matriz polimérica. Se houver um aumento no espaço interlamelar, o que caracteriza a entrada do polímero entre as camadas da argila, haverá um deslocamento do pico do plano $d_{001}$ para ângulos menores. Entretanto, a ausência desse pico indicará a formação de uma estrutura esfoliada e a não alteração do pico $d_{001}$ indicará que não houve qualquer tipo de interação entre a argila e o polímero.

\subsubsection{Liofilização das membranas para as análises de microscopia eletrônica de varredura e microscopia de força atômica.}

A liofilização é um processo de conservação de produto que envolve os dois métodos existentes confiáveis: congelamento e desidratação. Para ser liofilizada, primeiro a membrana de hidrogel foi congelada a uma temperatura -22 ํㅡ e depois submetida a vácuo, fazendo com que a água das membranas fosse retirada por sublimação. O resultado final é uma membrana com uma estrutura porosa e livre de umidade, sendo capaz de ser reconstruída pela simples adição de água. Foi usado para tal, um liofilizador de bancada linha Enterprise da TERRONI Equipamentos Científicos LTDA, FIG. 26.
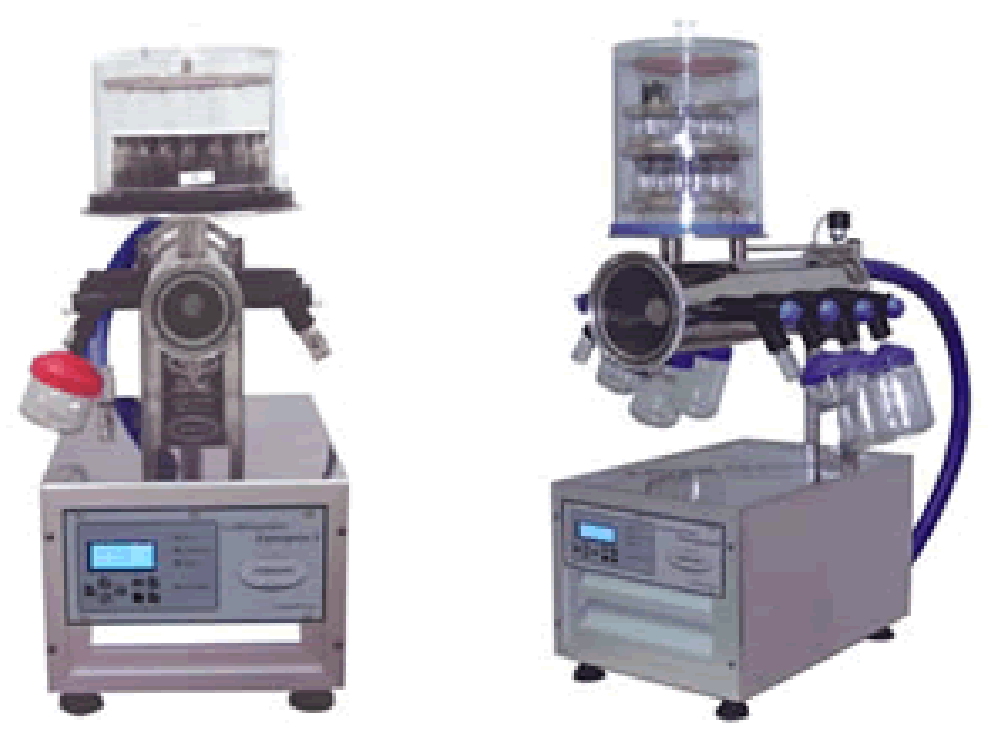

FIGURA 26 - Imagem do liofilizador de bancada. 
4.2.7 Microscopia eletrônica de varredura com emissão de campo (MEV$\mathrm{EC})$.

A técnica foi utilizada para verificação das estruturas poliméricas. Para a obtenção de alta resolução das estruturas em escala nano e micro, usando baixa tensão na faixa de $5 \mathrm{kV}$. O aparelho JSM-6701F ilustrado na FIG. 27 está alocado no Centro de Ciência e Tecnologia de Materiais (CCTM) do IPENCNEN/SP.

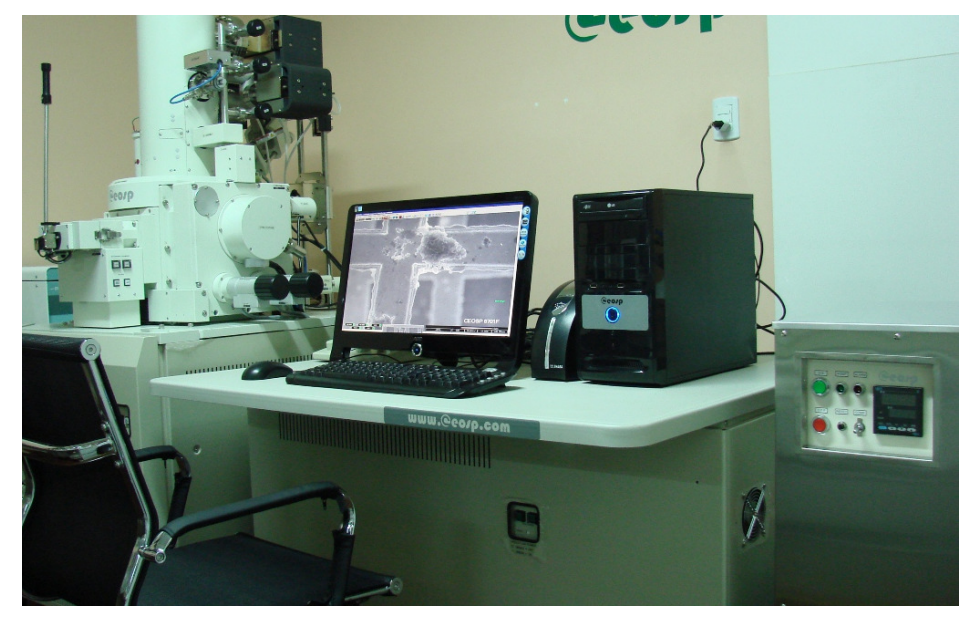

FIGURA 27 - Imagem do microscópio eletrônico de varredura por emissão de campo (MEV-EC).

\subsubsection{Espectrometria de energia dispersiva de raios X - EDS}

Para as análises usando a técnica EDS, foi liofilizada e preparada a superfície de fratura para identificação dos íons. Além da identificação dos íons, foi realizado o mapeamento da distribuição dos elementos químicos dos minerais, gerando mapas composicionais de elementos desejados e a quantificação dos íons. A FIG. 28 apresenta o aparelho EDS modelo Hitachi TM -3000. 


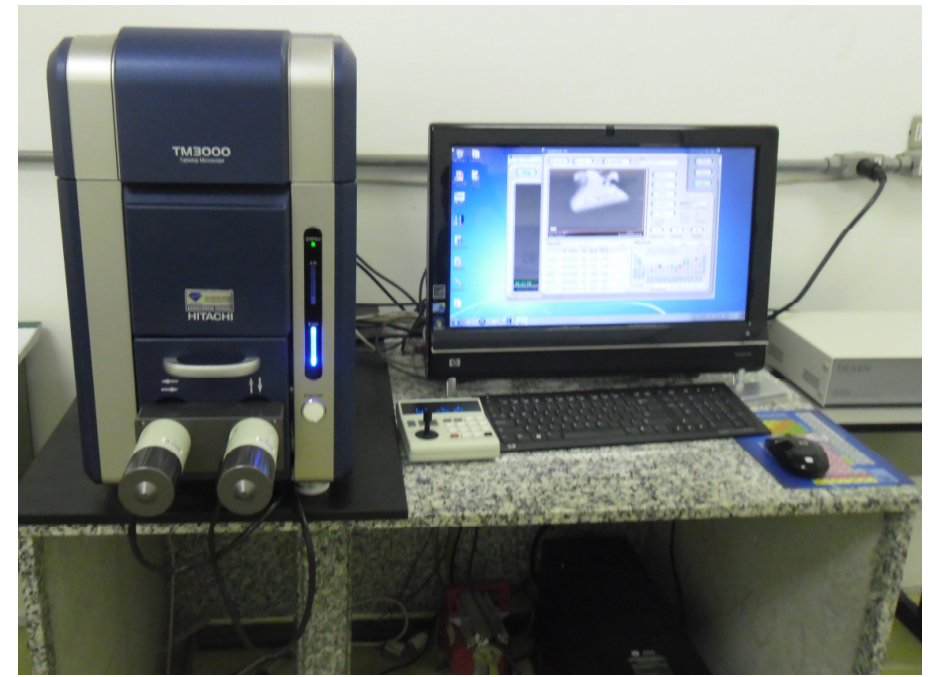

FIGURA 28 - Imagem do aparelho de espectrometria de energia dispersiva de raios $X$ - EDS.

\subsubsection{Microscopia de força atômica (AFM)}

A técnica AFM foi usada para verificação das superfícies das amostras. Essa técnica tem sido muito difundida para o estudo de polímeros, uma vez que permite obter novas informações sobre a superfície de polímeros, tais como morfologia, distribuição de fase em blendas e compósitos, dados tribológicos, conformações de cadeias poliméricas, entre outros. Utilizou-se o equipamento SOLVER (Scanning Pobre Microscope) NT-MDT, do Laboratório Nacional de Luz Síncrotron (LNLS), Campinas SP, mostrado na FIG. 29.

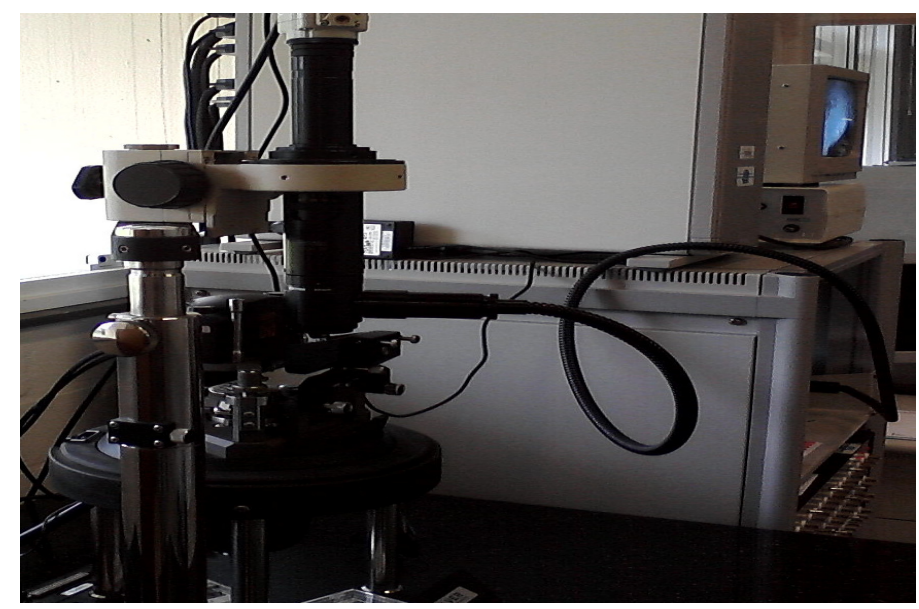

FIGURA 29 - Aparelho SOLVER (Scanning Probe Microscope) NT-MDT, alocado no laboratório Sicrontron (LNLS) Campinas -SP. 


\subsubsection{Liberação do fármaco}

As amostras dos hidrogéis com o glucantime foram colocadas em frascos com $40 \mathrm{~mL}$ de água e postas em uma incubadora com temperatura controlada a $37,0^{\circ} \mathrm{C}$ e agitação de $100 \mathrm{rpm}$, após 2 horas do início do experimento foi colhida uma alíquota de $2 \mathrm{~mL}$ e a cada 3 horas foram colhidas alíquotas por um período de 12 horas, outras alíquotas de $2 \mathrm{~mL}$ com 24, 36 e 48 horas de ensaio. A FIG. 30 apresenta a incubadora modelo TE-420 da TECNAL.

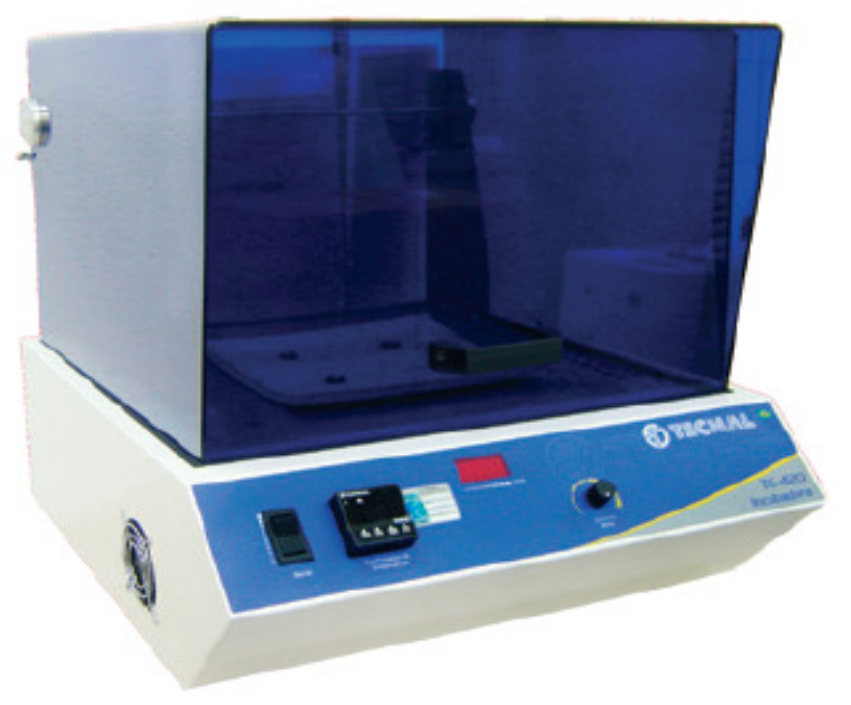

FIGURA 30 - Imagem da incubadora modelo TE-420 da TECNAL.

\subsubsection{Espectrofotometria UV - visível}

Usando-se um espectrofotômetro B582 da Micronal foram feitas leituras em $\lambda=510 \mathrm{~nm}$, para determinar a concentração do antimoniato liberado pelas membranas de hidrogéis. As leituras foram feitas em lâmpada de halogênio em cubetas de vidro óptico para trabalho na faixa de 360 a $1000 \mathrm{~nm}$. O aparelho usado esta representado na FIG. 31. 


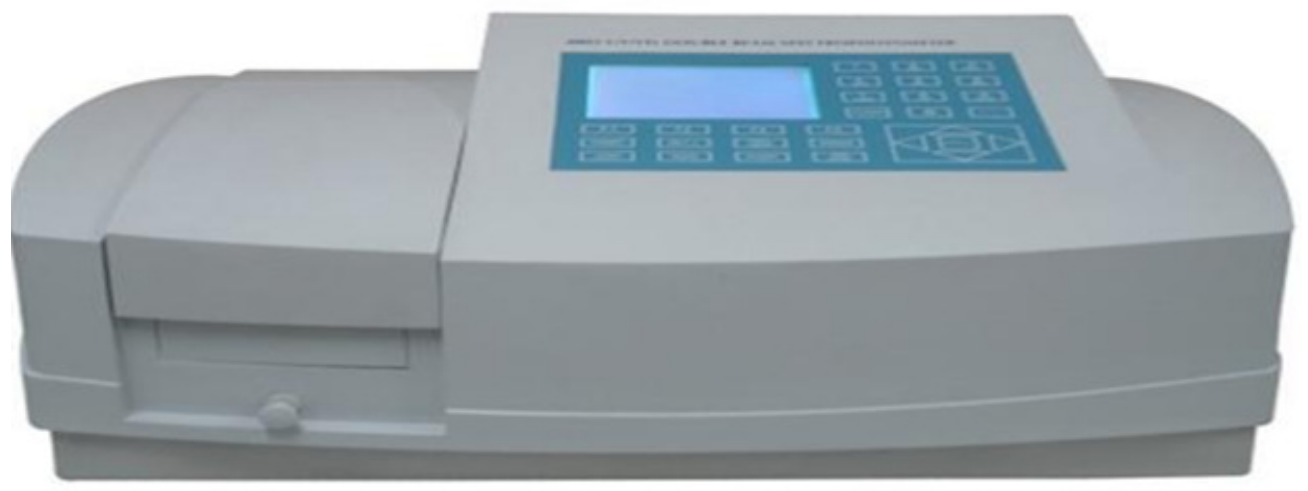

FIGURA 31 - Imagem do aparelho de espectrofotometria UV-visível.

\subsubsection{Curva de calibração do antimoniato.}

Foram usados $3,0 \mathrm{~mL}$ de solução tampão de $\mathrm{pH}=2,0 ; 2,0 \mathrm{~mL}$ da solução vermelho pirogalol e uma alíquota de $1 \mathrm{~mL}$ das soluções de 0,5 a 2,5 $\mu \mathrm{g}$ $\mathrm{mL}^{-1}$ de antimoniato de potássio (SbV) que foram colocados em balão volumétrico de $10 \mathrm{~mL}$ e completados com água destilada. Esperou-se por trinta minutos para formar o complexo e fez-se a leitura no comprimento de onda de $510 \mathrm{~nm}$. Três alíquotas foram usadas para cada valor de concentração de $\mathrm{Sb}(\mathrm{V})$. A respectiva curva de calibração conforme o método Abbaspour, 2004, está ilustrado na FIG. 32.

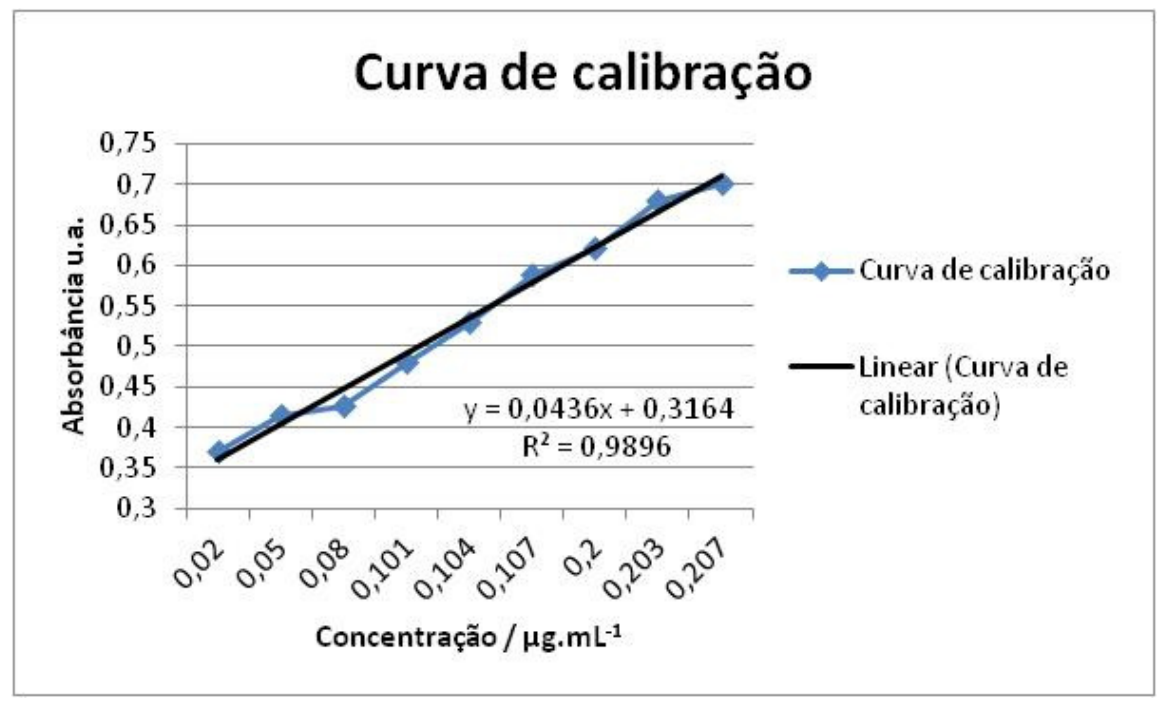

FIGURA 32 - Curva de calibração de antimoniato (Sb V) mostrando concentração versus absorbância em $\lambda=510 \mathrm{~nm}$. 


\subsubsection{Espectrômetro de absorção atômica com atomização por forno de} grafita.

A determinação da liberação do fármaco foi feita por espectrômetro de absorção atômica, utilizando as soluções liberada pelo modo dinâmico e pelo modo estático, para confirmar a eficiência da liberação do fármaco.

O Espectrômetro de absorção atômica é uma técnica que permite a análise quantitativa de elementos metálicos, iônicos em líquidos, sólidos ou gasosos. A atomização foi feita eletrotermicamente em chama forno de grafita, ilustrado na FIG. 33, para quantificar o antimônio presente no glucantime liberado pela membrana de hidrogel no período de $48 \mathrm{~h}$ nos diversos sistemas.

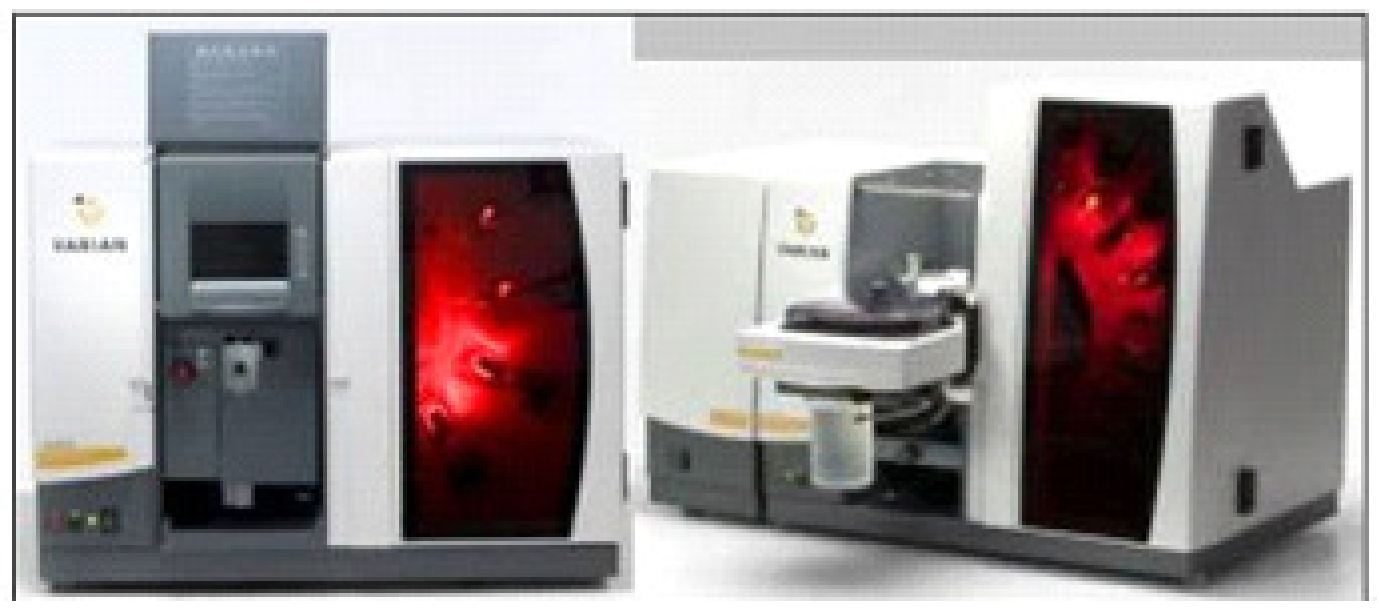

FIGURA 33 - Espectrômetro de absorção atômica com atomização por forno de grafita.

\subsubsection{Citotoxicidade}

Os testes preliminares de citotoxicidade dos hidrogéis obtidos foram realizados "in vitro" utilizando-se o método de incorporação do vermelho neutro seguindo normas internacionais (ISO 10993-1, 10993-5) e metodologia descrita anteriormente (Rogero, 2003).

A biocompatibilidade pode ser definida como a capacidade de um material funcionar com uma resposta apropriada do hospedeiro em uma aplicação 
específica (Williams, 1986). O primeiro critério para verificar a biocompatibilidade de um material é a avaliação de sua citotoxicidade. A utilização de testes "in vitro" funciona como uma triagem inicial na primeira fase de avaliação da biocompatibilidade, minimizando o uso de animais em pesquisa.

No teste de citotoxicidade foram utilizadas células da linhagem NCTC Clone 929 (células de tecido conectivo de camundongo) da American Type Culture Colection (ATCC). Como controle negativo foi usado o polietileno de alta densidade (HDPE) e como controle positivo, filme de látex de borracha natural. $\mathrm{O}$ cultivo das células e a distribuição da suspensão celular na microplaca de 96 poços foram feitos e cedidos pelo Departamento de Culturas Celulares do Instituto Adolfo Lutz.

Para obtenção dos extratos, as amostras e os controles foram imersos em meio mínimo de Eagle (MEM) adicionado de soro fetal bovino, piruvato de sódio e aminoácidos não essenciais e incubados durante $24 \mathrm{~h}$ a $37^{\circ} \mathrm{C}$. Para cada $1 \mathrm{~cm}^{2}$ de área superficial da amostra e do látex foi adicionado $1 \mathrm{~mL}$ de MEM e para cada 0,5 g de HDPE foram adicionados $5 \mathrm{~mL}$ do meio de cultura. Após este período, os extratos obtidos foram diluídos em série $(100 \%, 50 \%, 25 \%, 12,5 \%$ e $6,25 \%$ ) e colocados em contato com a monocamada de células nos poços da microplaca de 96 poços em triplicata. A microplaca contendo os extratos foi colocada em estufa com atmosfera úmida e $5 \%$ de $\mathrm{CO}_{2}$, a $37^{\circ} \mathrm{C}$ por 24 horas.

Os extratos foram substituídos por solução de corante vermelho neutro e a microplaca foi novamente colocada em estufa à $37^{\circ} \mathrm{C}$ durante $3 \mathrm{~h}$, para que 0 corante fosse incorporado pelas células vivas. Após 3 horas, a solução de vermelho neutro foi desprezada, a microplaca lavada com solução tampão fosfato de $\mathrm{pH}$ 7,4 e cada poço da microplaca preenchido com $200 \mu \mathrm{L}$ de solução de lavagem (10\% de $\mathrm{CaCl}_{2}$ em solução de formaldeído 0,5\%). Após lavagem, foram colocados $200 \mu \mathrm{L}$ de solução de extração (50\% de ácido acético $2 \%$ e $50 \%$ etanol para lise das células vivas e liberação do corante incorporado).

A porcentagem de viabilidade celular foi calculada pelas leituras de densidade óptica (DO) realizadas a $540 \mathrm{~nm}$ em espectrofotômetro modelo Sunrise 
da Tecan, tomando-se como referência a DO do controle de células no ensaio. A medida da citotoxicidade foi realizada pelo cálculo do índice de citotoxicidade IC50\% que é a concentração do extrato que reduz em $50 \%$ a viabilidade celular no ensaio. A TAB. 10 apresenta distribuição dos extratos das amostras e controle na microplaca.

TABELA 10 - Apresentação do esquema da distribuição dos extratos das amostras e controle na microplaca.

\begin{tabular}{|c|c|c|c|c|c|c|c|c|c|c|c|c|}
\hline & 1 & 2 & 3 & 4 & 5 & 6 & 7 & 8 & 9 & 10 & 11 & 12 \\
\hline A & $100 \%$ & $100 \%$ & $100 \%$ & $100 \%$ & $100 \%$ & $100 \%$ & $100 \%$ & $100 \%$ & $100 \%$ & $100 \%$ & $100 \%$ & $100 \%$ \\
\hline B & $50 \%$ & $50 \%$ & $50 \%$ & $50 \%$ & $50 \%$ & $50 \%$ & $50 \%$ & $50 \%$ & $50 \%$ & $50 \%$ & $50 \%$ & $50 \%$ \\
\hline C & $25 \%$ & $25 \%$ & $25 \%$ & $25 \%$ & $25 \%$ & $25 \%$ & $25 \%$ & $25 \%$ & $25 \%$ & $25 \%$ & $25 \%$ & $25 \%$ \\
\hline D & $12,5 \%$ & $12,5 \%$ & $12,5 \%$ & $12,5 \%$ & $12,5 \%$ & $12,5 \%$ & $12,5 \%$ & $12,5 \%$ & $12,5 \%$ & $12,5 \%$ & $12,5 \%$ & $12,5 \%$ \\
\hline E & $6,25 \%$ & $6,25 \%$ & $6,25 \%$ & $6,25 \%$ & $6,25 \%$ & $6,25 \%$ & $6,25 \%$ & $6,25 \%$ & $6,25 \%$ & $6,25 \%$ & $6,25 \%$ & $6,25 \%$ \\
\hline F & MEM & MEM & $100 \%$ & $50 \%$ & $25 \%$ & $12,5 \%$ & $6,25 \%$ & $100 \%$ & $50 \%$ & $25 \%$ & $12,5 \%$ & $6,25 \%$ \\
\hline G & MEM & MEM & $100 \%$ & $50 \%$ & $25 \%$ & $12,5 \%$ & $6,25 \%$ & $100 \%$ & $50 \%$ & $25 \%$ & $12,5 \%$ & $6,25 \%$ \\
\hline H & MEM & MEM & $100 \%$ & $50 \%$ & $25 \%$ & $12,5 \%$ & $6,25 \%$ & $100 \%$ & $50 \%$ & $25 \%$ & $12,5 \%$ & $6,25 \%$ \\
\hline
\end{tabular}

\section{Legenda:}

Amostra
1

\begin{tabular}{|l|}
\hline Amostra \\
2
\end{tabular}

\begin{tabular}{|l|}
\hline Amostra \\
3
\end{tabular}

Amostra
4

\begin{tabular}{|l|}
\hline $\begin{array}{l}\text { Controle de } \\
\text { células }\end{array}$ \\
\hline
\end{tabular}




\subsection{Protocolo de Ética}

A Comissão de Pesquisa e Ética e Comissão de Ética no uso de animais em pesquisa, do Instituto de Medicina Tropical de São Paulo, analisaram e aprovaram, no que diz respeito aos aspectos de natureza da ética em experimentação animal, o projeto de pesquisa classificado sob número, CPE-IMT 2010/072, "Síntese e caracterização de nanogel e micro hidrogel para liberação de fármaco "in vivo" no tratamento da leishmaniose" 25 de agosto de 2010.

A finalidade do projeto foi obter o maior número possível de informações relevantes com um pequeno número de animais por grupo, seguindo assim recomendações dos Comitês de Ética em experimentação animal. A referência o modelo de Ghaffarifar 2010, que utilizou de 6 a 10 camundongos por grupo, para cada análise, cujos resultados foram validados e aceitos pela comunidade científica.

\subsubsection{Procedência dos modelos experimentais (camundongos Balb/C)}

O camundongo Balb/C (Mus domesticus), isogênico, configura-se na linhagem mais utilizada em estudos experimental suscetível à leishmaniose. Os animais usados neste estudo foram procedentes do Biotério da Faculdade de Medicina de São Paulo e foram mantidos no Biotério do Laboratório de Parasitologia do IMT-USP e LIM/46 até a sua utilização final.

\subsubsection{Purificação de amastigotas}

1 - Sacrificou-se o modelo experimental infectado, um camundongo Balb/C de aproximadamente $17 \mathrm{~g}$; em seguida retiraram-se as patas com lesões típicas da LTA, que foram colocadas em álcool absoluto, imersas por aproximadamente um minuto.

2 - Removeu-se toda a pele necrosada de lesão das patas do camundongo causada pela L. amazonensis, lavando-se com álcool absoluto. 
3 - Os fragmentos de lesões foram colocadas no RPMI ou PBS-EDTA $2 \mathrm{mM}$, por 2 min, macerando-se em seguida.

4 - Obteve-se uma suspensão que foi filtrada e sedimentada por 10 min, mantida em banho de gelo na geladeira.

5 - O sobrenadante foi centrifugado a $1500 \mathrm{rpm}$ por $1 \mathrm{~min}$. Após obtenção de novo sobrenadante, foi repetido o procedimento por mais $10 \mathrm{~min}$.

6 - A partir do sedimento, contou-se em câmara de Neubauer, diluindose a 1:10 (10 de parasita+90 de formol $+2 \%$ PBS). A seguir diluiu-se 1/100 com violeta cristal para facilitar a contagem devido ao grande número de parasitas.

7 - Quantificaram-se os parasitas de acordo com a necessária para a infecção, utilizando-se de $10^{4}$ a $10^{5}$ para infecção de camundongos, com a finalidade de manter a cepa e realizar os experimentos. 
4.3.3 Inoculação dos modelos experimentais para uso das matrizes de hidrogéis com o glucantime

O fluxograma da FIG. 34 apresenta o procedimento escolhido para a inoculação do $1^{\circ}$ grupo de animais tratados.

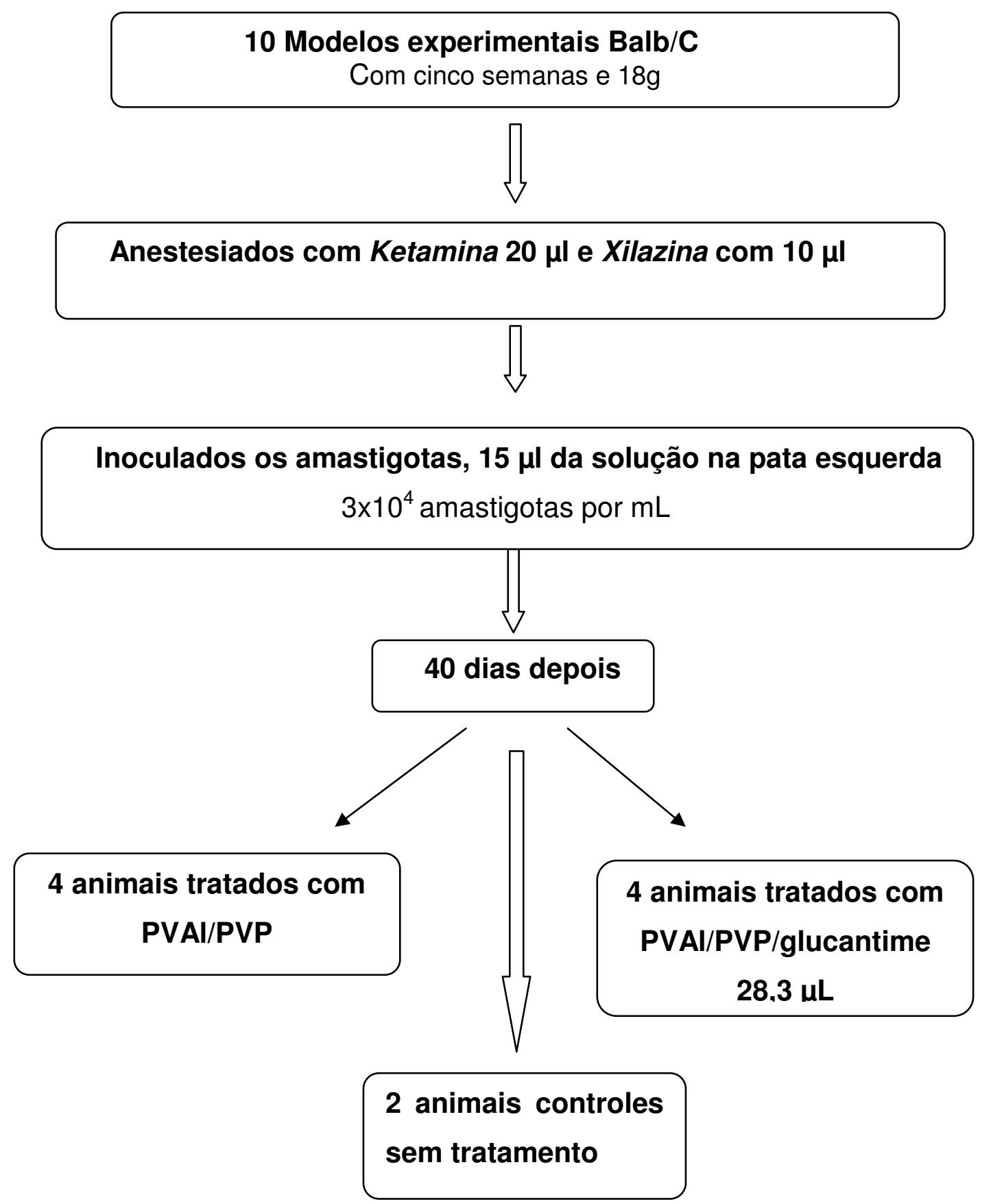

FIGURA 34- Fluxograma do procedimento escolhido para a inoculação dos modelos experimentais. 
O fluxograma da FIG. 35 apresenta o procedimento escolhido para a inoculação do $2^{\circ}$ grupo de animais tratados.

6 Modelos experimentais Balb/C

Com cinco semanas e $18 \mathrm{~g}$

$\sqrt{l}$

Anestesiados com Ketamina $20 \mu \mathrm{l}$ e Xilazina com $10 \mu \mathrm{l}$<smiles>[C]=C</smiles>

Inoculados os amastigotas, $15 \mu \mathrm{l}$ da solução na pata esquerda $3 \times 10^{4}$ amastigotas por $\mathrm{mL}$

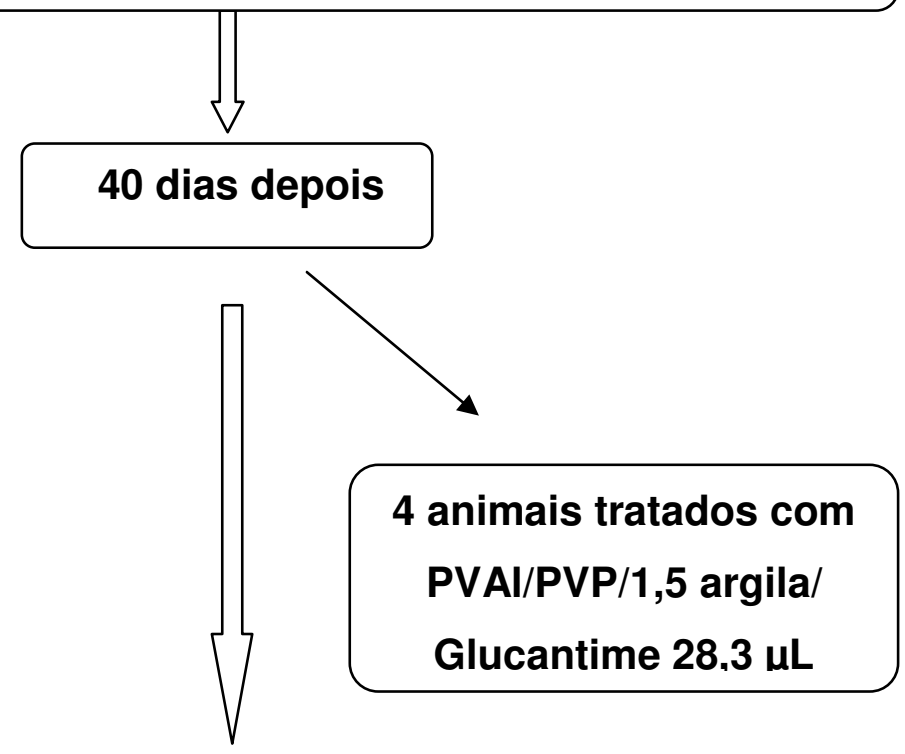

2 animais controles sem tratamento

FIGURA 35 - Fluxograma do procedimento escolhido para a inoculação dos modelos experimentais. 
O fluxograma da FIG. 36 apresenta o procedimento escolhido para a inoculação do $3^{\circ}$ grupo de animais tratados.

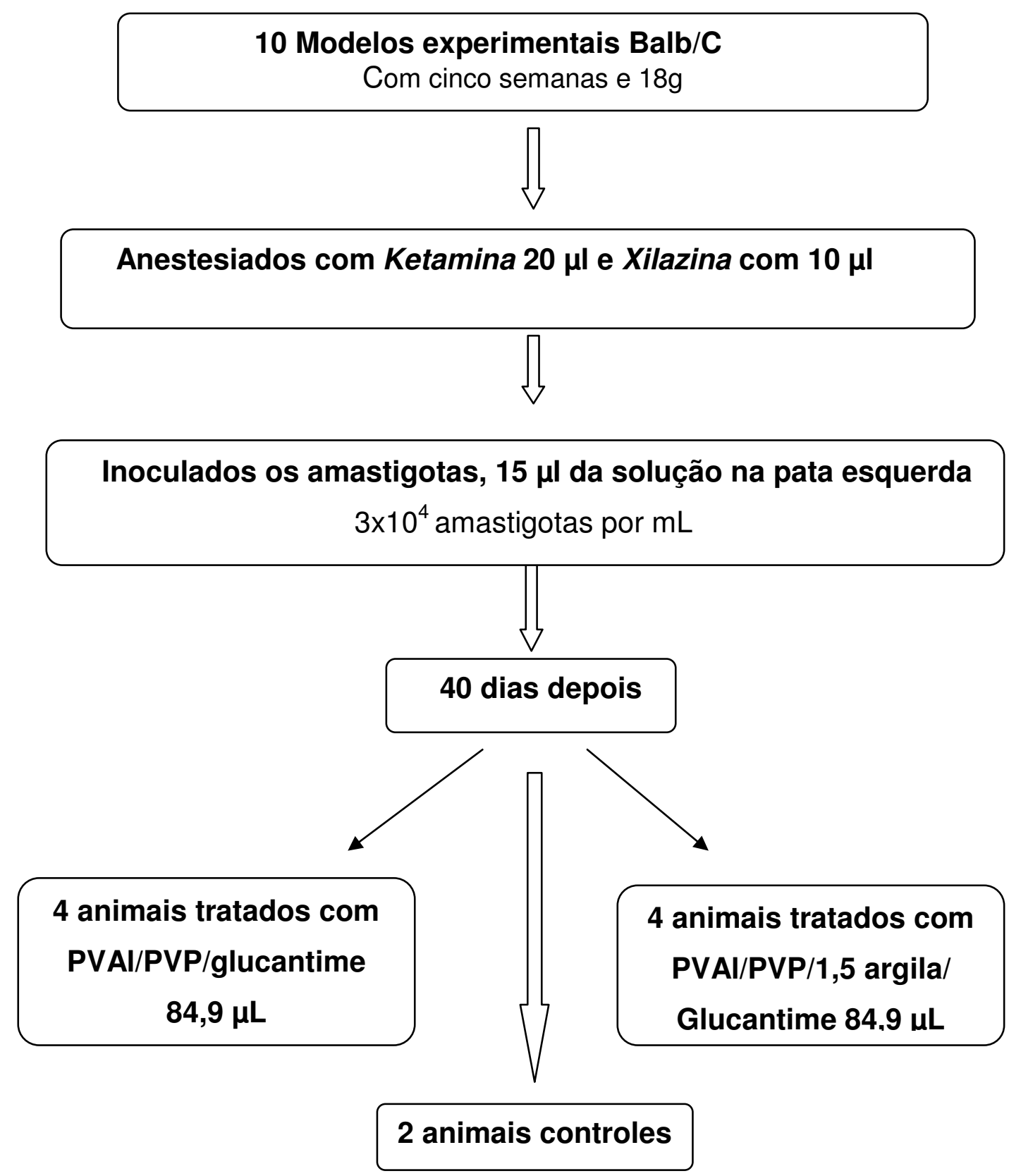

FIGURA 36- Fluxograma do procedimento escolhido para a inoculação dos modelos experimentais. 


\subsubsection{Avaliação de lesões dos camundongos Balb/C}

Trinta a quarenta dias após inoculação na pata traseira, todos os camundongos apresentaram lesões significativas e o curativo foi utilizado de acordo com a FIG. 37 (A e B).
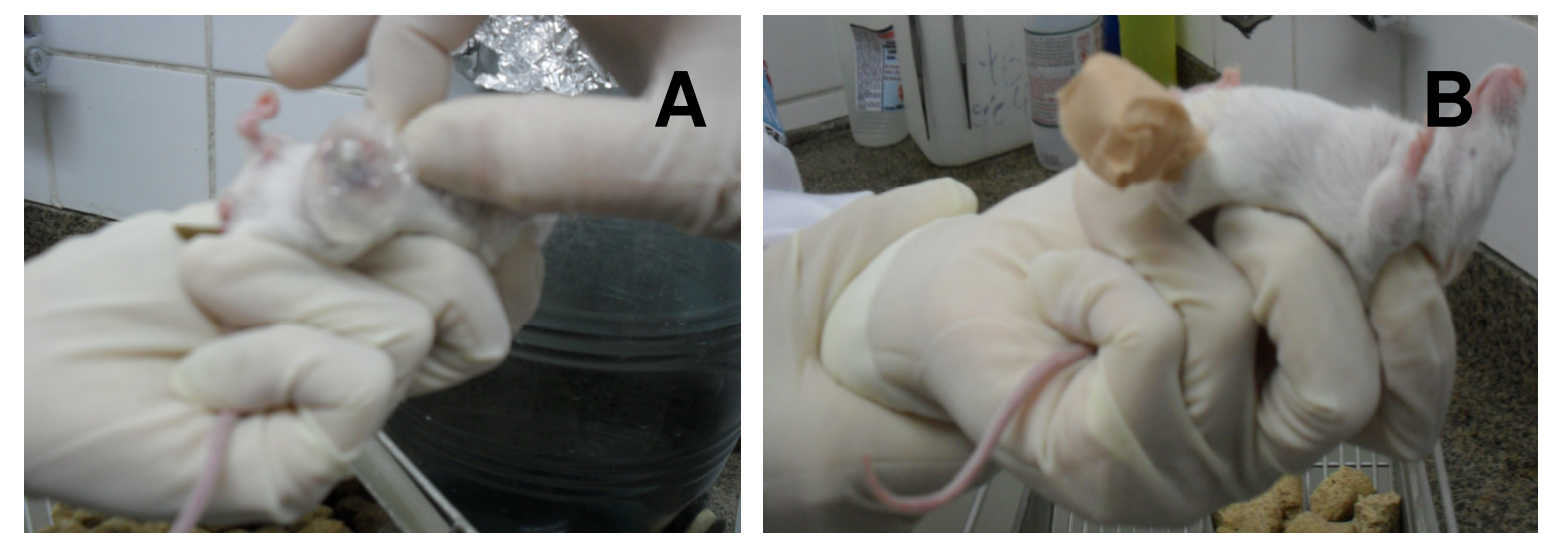

FIGURA 37 - As fotos apresentam a sequência dos curativos de hidrogéis ( $A$ e $B$ ).

O procedimento para $01^{\circ}, 2^{\circ}$ e $3^{\circ}$ grupo ocorreu na seguinte sequência:

$1^{\circ}$ Os curativos foram colocados sobre as lesões cutâneas por 48 horas;

$2^{0}$ Retirou-se os curativos e deixou-se o ferimento exposto por 24 horas;

$3^{\circ}$ Alternou-se este procedimento por um período de 60 dias. 


\section{RESULTADOS E DISCUSSÕES}

Seguindo uma sequência de resultados a partir dos testes preliminares, as membranas de hidrogéis PVAl/PVP/argila foram obtidas em três concentrações de argila. Em algumas concentrações, as membranas apresentaram-se firmes, com boa consistência no fundo da placa, tendo na superfície uma forma de gel líquido. Em outras formulações as membranas de hidrogéis apresentaram quebradiças com pouca consistência, como mostra a FIGURA 38. Essas formulações foram repetidas e submetidas à irradiação nas doses de 10 a 30 kGy e não apresentaram alterações significativas nos resultados.
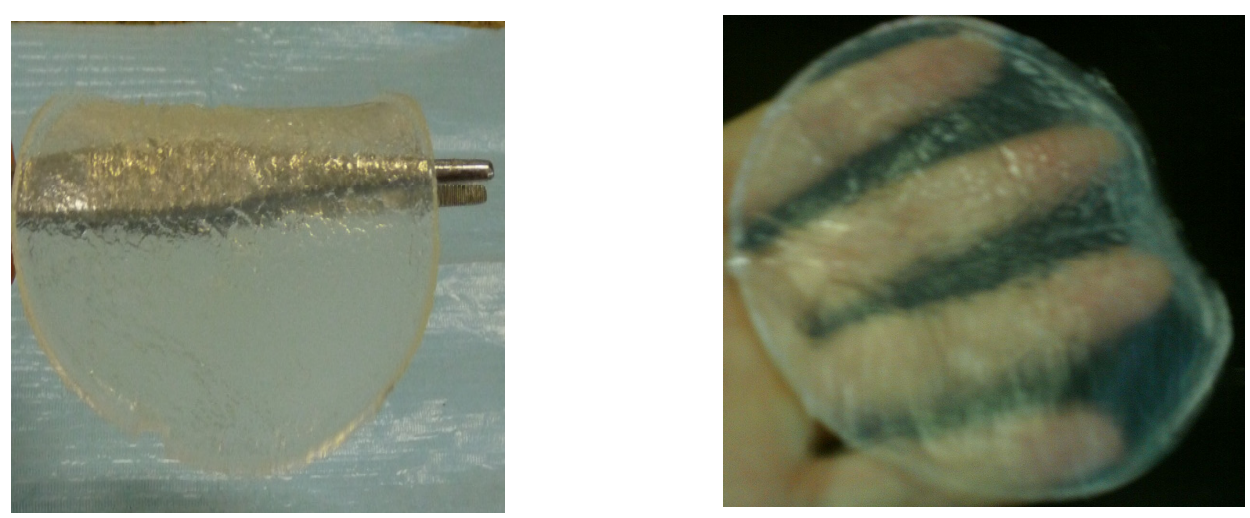

FIGURA 38 - Membranas de hidrogéis com superfícies quebradiças.

Entretanto após o teste prévio, verificou-se que o plástico que cobria a membrana de hidrogel para protegê-la durante a irradiação, por ser um filme muito fino e com pouca resistência, sofria degradação quando irradiado. Isto fazia com que a superfície da amostra ficasse desprotegida, contribuindo para a sua oxidação, e considerando ainda o tempo longo de irradiação de 12 h e 45 min em fonte cobalto à taxa de dose de 1,89 kGy.h ${ }^{-1}$ (atividade do irradiador do IPEN), formando duas fases: uma reticulada no fundo da placa e outra na superfície, em que ocorria degradação.

Baseado nas formulações de mestrado [Oliveira, 2008], irradiadas a 5,72 kGy.h ${ }^{-1}$ foram testados lotes com formulações de PVP/PVAl/argila; PVAl/argila; PVP/argila; PVP/quitosana/argila e PVAl/quitosana/argila, irradiadas por $2 \mathrm{~h}$ e 25 min. Essas membranas apresentaram maciez, flexibilidade e não 
pegajosidade, que são os pré-requisitos para o processo de obtenção da membrana.

Quando realizados os testes preliminares observou-se que para as membranas de PVAl/quitosana/argila apenas a dose de 25 kGy apresentou boas condições físicas de membrana, maior flexibilidade e não pegajosidade. Portanto, foi determinado a condição de dose de 25 kGy em taxa de dose de 5,72 kGy.h ${ }^{-1}$, para reticular todas as membranas sintetizadas do presente estudo. $E$ a partir das caracterizações das membranas assim reticuladas puderam ser comparados os resultados obtidos entre os sistemas desenvolvidos.

O esquema da FIG. 39 representa os sistemas de hidrogéis e a sequência de apresentação dos resultados.

\section{PVAI / PVP / argila}

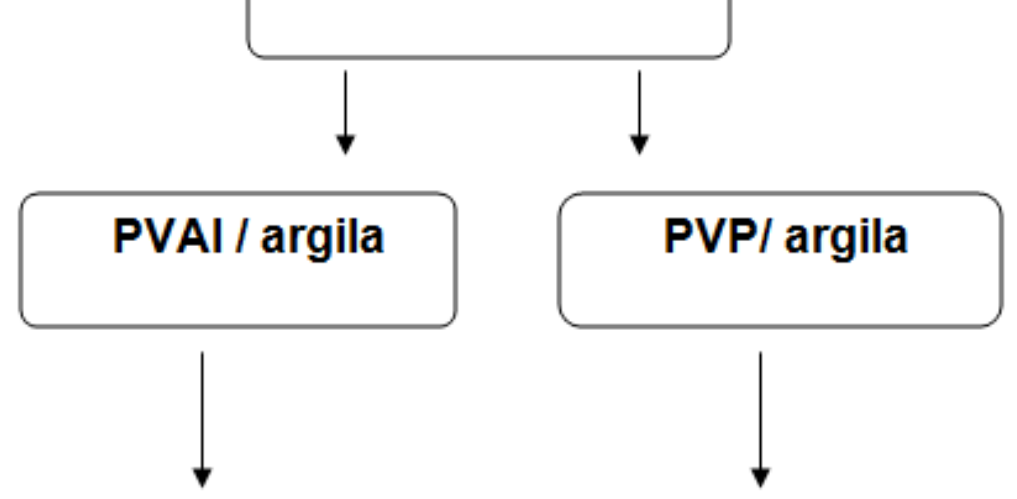

PVAI /quitosana /argila

PVP / quitosana / argila

FIGURA 39 - Esquema dos sistemas e sequência dos resultados 


\subsection{Resultados dos hidrogéis obtidos do sistema PVAl/PVP e PVAI/PVP/ argila - intumescimento e fração gel em triplicata}

As membranas de hidrogéis PVAl/PVP e PVAl/PVP/0,5\% argila apresentaram curvas de intumescimento semelhantes, enquanto a matriz de PVAl/ PVP/1,0\% de argila apresentou maior intumescimento. Nota-se que as menores quantidade de argila favorecem o intumescimento, comparando-se com a matriz PVAl/PVP/1,5\% de argila que apresenta menor intumescimento. Essa redução pode ser relacionada às ligações covalentes obtidas pelos radicais livres durante a reticulação por radiação gama. Também pode ser observado que 0 tempo do equilíbrio de intumescimento das matrizes ocorre em $10 \mathrm{~h}$. Em geral, o equilíbrio de intumescimento do hidrogel depende do rearranjo das moléculas após a reticulação e da interação polímero argila, conforme ilustrada na FIG. 40.

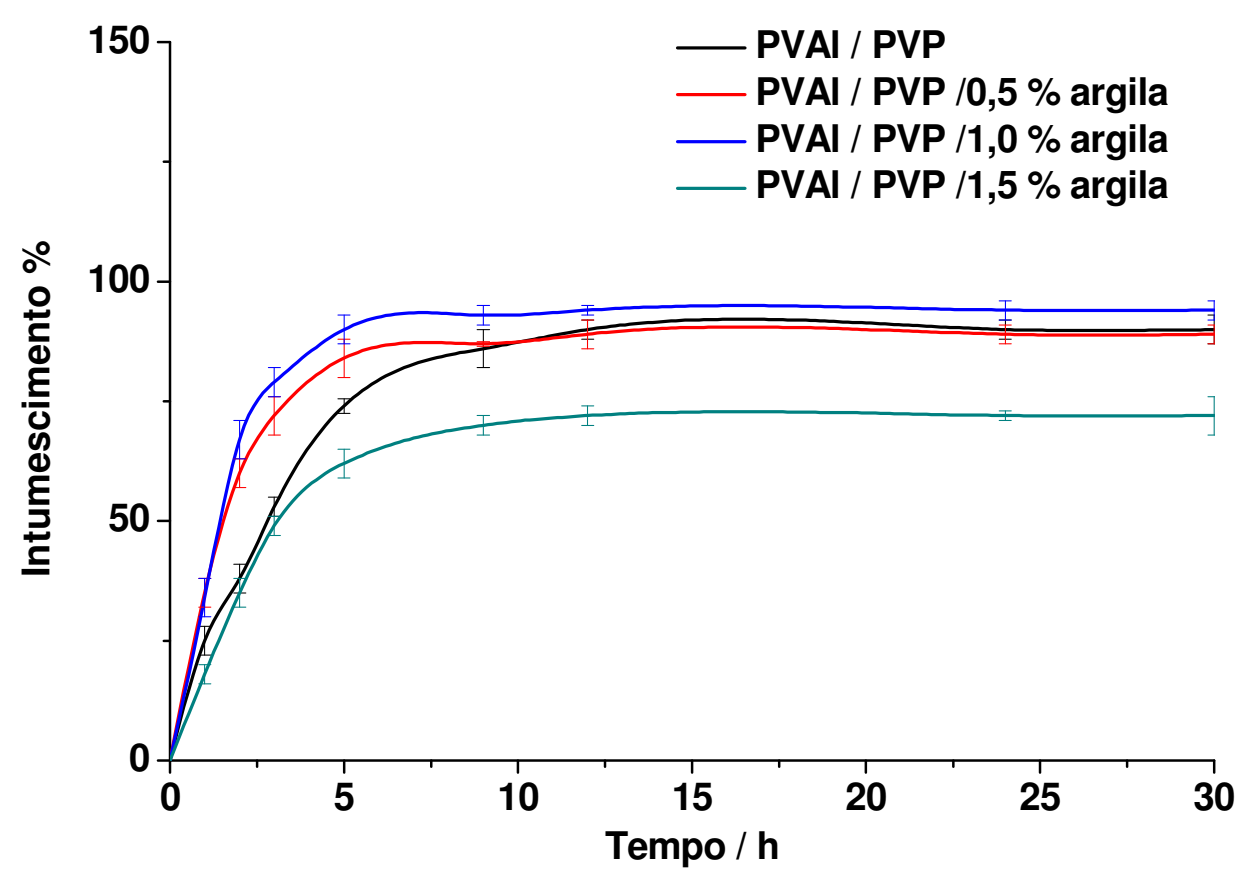

FIGURA 40 - Curvas de intumescimento dos hidrogéis de PVAl/PVP/argila, obtidos por irradiação gama, dose de 25 kGy.

O comportamento das curvas de intumescimento pode ser justificado de acordo com as interações de polímero argila no sistema aquoso. A água compete com os sítios de adsorção do polímero na superfície sólida da argila, 
particularmente quando ocorrem ligações de hidrogênio. Sendo bifuncional, a água pode agir como doadora ou receptora de íons e sua presença na superfície pode promover ou inibir a adsorção do polímero. É importante lembrar que moléculas de água na superfície da argila estão associadas aos cátions trocáveis, devido ao oxigênio basal nos silicatos 2:1 (superfície siloxano) serem fracos doadores de elétrons. Portanto, a interação por ligação de hidrogênio entre água e a superfície não é muito forte (Theng, 1979). Além da reticulação por radiação gama formada pelos radicais existem estas interações na formação da rede tridimensional aumentando ou limitando esse intumescimento.

No que se refere à fração gel, estudos realizados por Razzak (2001) utilizando blendas de PVP e PVAl irradiadas a 20 kGy apresentaram cerca de $80 \%$ de fração gel, valor próximo ao obtido das matrizes de hidrogéis irradiadas a 25 kGy, estudadas neste trabalho, como pode ser observado na TAB. 11.

A fração gel para esse sistema PVAl/PVP/argila apresenta valores próximos para todas as membranas. Supõe-se que os radicais formados são utilizados na formação de rede entre os polímeros sendo que a argila não interferiu nesse mecanismo.

TABELA 11- Fração gel dos hidrogéis PVAl/PVP/argila, obtidos por irradiação gama, na dose de 25 kGy.

\begin{tabular}{ll}
\hline Membranas & Fração gel (\%) \\
& Média + desvio padrão \\
\hline PVAl/PVP & $70 \pm 2$ \\
PVAl/PVP/0,5\% argila & $69 \pm 1$ \\
PVAl/PVP/1,0\% argila & $71 \pm 1$ \\
PVAl/PVP/1,5\%argila & $70 \pm 2$ \\
\hline
\end{tabular}




\subsection{Resultados dos hidrogéis obtidos dos sistemas PVAl/argila e PVP/ argila - intumescimento e fração gel.}

O intumescimento para o sistema PVAl/argila variando-se a concentração da argila o intumescimento foi inferior para PVAl/1,0 e 1,5\% argila se comparado com das membranas PVAl e PVAI/0,5 argila. Observa-se que a concentração da argila interfere na reticulação do polímero, conforme mostra a FIG. 41, em que a argila tende a restringir o intumescimento com o PVAI na rede tridimensional.

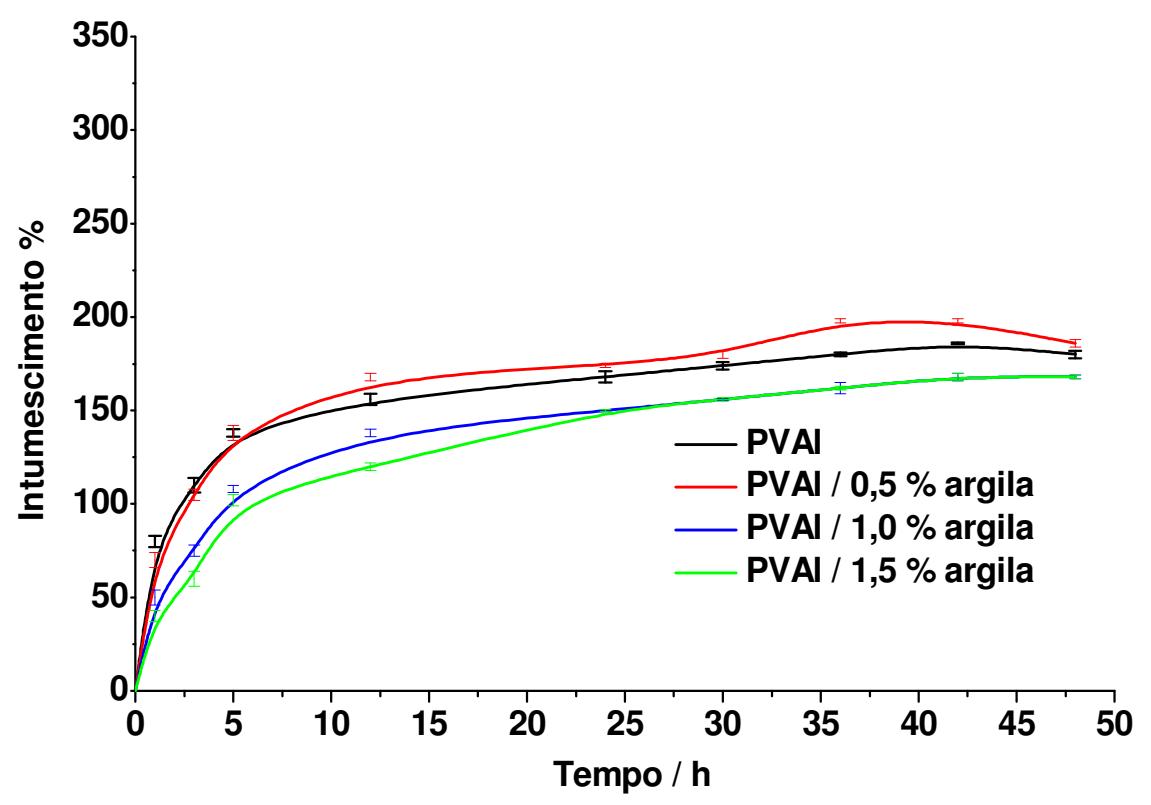

FIGURA 41 - Curvas de intumescimento das membranas de hidrogéis PVAl/argila, obtidos por radiação gama, dose de 25 kGy.

Para as curvas de intumescimento do PVP/argila observam-se mudanças mais coerentes após quatro horas de ensaio. Onde o intumescimento é superior para o PVP 0,5\% e 1,0\% de argila comparando-se ao PVP puro e PVP com $1,5 \%$ de argila, FIG. 42. 


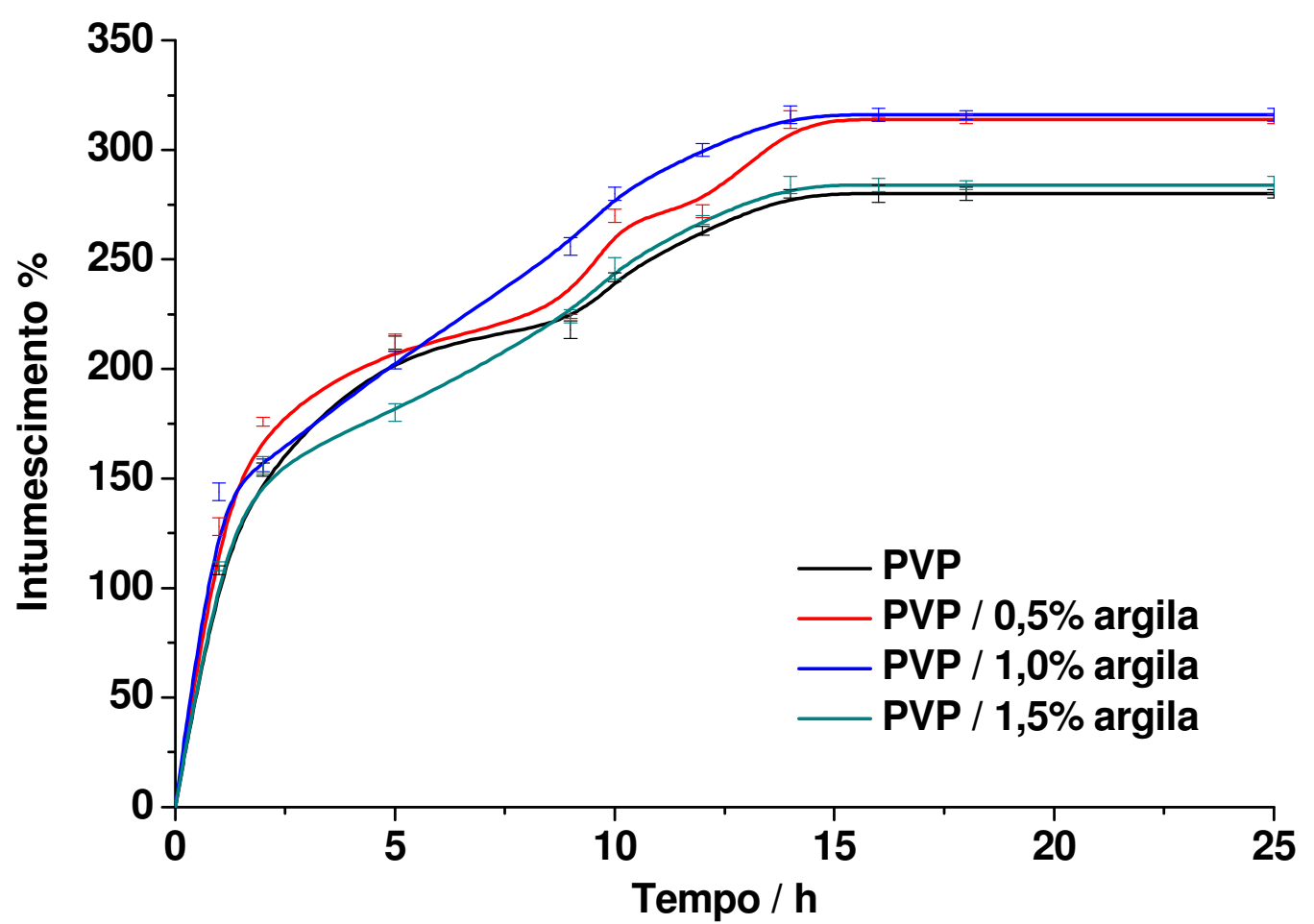

FIGURA 42 - Curvas de intumescimento das membranas de hidrogéis PVP/argila obtidos por irradiação gama, dose de 25 kGy.

Observa-se um comportamento de intumescimento diferente entre os dois sistemas PVAl/argila e PVP/argila. É perceptível que para o sistema PVAl/argila FIG. 41, o começo do equilíbrio de intumescimento ocorre após 45 horas com $200 \%$ de intumescimento para a matriz com $0,5 \%$ de argila e $170 \%$ para as matrizes de 1,0 e 1,5\% de argila. Já o sistema PVP/argila FIG. 42, apresenta equilíbrio com apenas 15 horas e 320\% de intumescimento para 0,5 e $1,0 \%$ argila e para as matrizes PVP e PVP/1,5\% de argila, $280 \%$ de intumescimento.

Nota-se que para o sistema PVAl/argila, uma porcentagem maior de argila provoca uma diminuição no intumescimento, enquanto que para o sistema PVP/argila é observado que o aumento da concentração da argila para 1,5\% não interferiu no intumescimento, apresentando comportamento semelhante ao PVP.

Esse comportamento de intumescimento é associado a vários fatores que influenciam nas recombinações dos radicais formados pela radiação. Entre eles estão: as interações da argila com o polímero, os grupos funcionais ao longo 
da cadeia polimérica e a ionização da argila e ao PEG, que foi usado como um plastificante para aumentar a mobilidade e flexibilidade das membranas (Rodrigues, 1984; Tadmor, 1979).

No que se refere à fração gel nota-se que o sistema PVAl/argila aumenta a fração gel gradativamente de acordo com a porcentagem da argila, enquanto que as membranas de hidrogéis obtidos com PVP/0,5; 1,0 e 1,5\% argila apresentaram valores próximos de gel conforme mostra a TAB. 12.

TABELA 12 - Fração gel das membranas de hidrogéis PVAl/argila e PVP/argila, obtidos por irradiação gama com dose de 25 kGy.

\begin{tabular}{llll}
\hline Membranas & $\begin{array}{l}\text { Fração gel (\%) } \\
\text { Média+desvio } \\
\text { padrão }\end{array}$ & Membranas & $\begin{array}{l}\text { Fração gel (\%) } \\
\text { Média+desvio } \\
\end{array}$ \\
& $53 \pm 2$ & PVP & padrão \\
\hline PVAl & $58 \pm 1$ & PVP/0,5\% argila & $71 \pm 1$ \\
PVAl/0,5\% argila & $57 \pm 1$ & PVP/1,0\% argila & $71 \pm 1$ \\
PVAl/1,0\% argila & $69 \pm 1$ & PVP/1,5\% argila & $72 \pm 1$ \\
PVAl/1,5\% argila & & & \\
\hline
\end{tabular}

Observam-se porcentagens diferentes de gel entre os dois sistemas PVAl/argila e PVP/ argila. A quantidade de gel está associada ao rearranjo da cadeia polimérica, porque esses fatores interferem na reticulação aumentando ou diminuindo a formação das redes tridimensionais, podendo ocasionar regiões com maior densidade de gel promovida pelas ligações covalentes. 


\subsection{Resultados dos hidrogéis obtidos de PVAl/quitosana/argila - intumescimento e fração gel.}

O comportamento do sistema PVAl/quitosana/argila apresenta intumescimento com característica diferente dos sistemas ausentes de quitosana estudados e discutidos nos itens 5.1 e 5.2, conforme indica a FIG. 43.

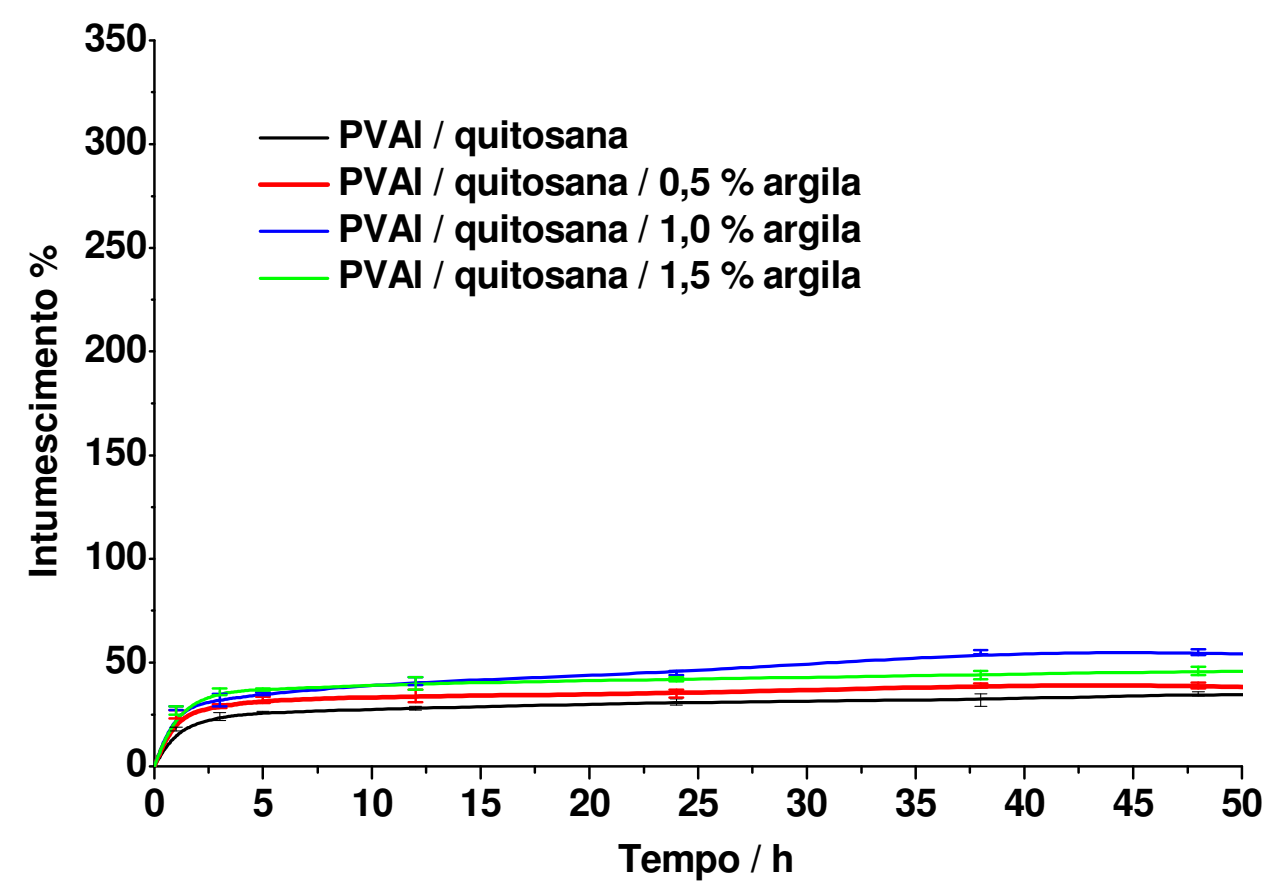

FIGURA 43 - Curvas de intumescimento dos hidrogéis PVAl/quitosana/argila obtidos por radiação gama, dose de 25 kGy.

Nota-se que para o sistema PVAl/quitosana/argila quando há aumento da porcentagem desta última há também o aumento do intumescimento, inversamente do que ocorre com o sistema PVAl/argila quando um aumento da porcentagem da argila diminui o intumescimento. Um dos fatores importantes para a diferença de intumescimento entre os dois sistemas é a reticulação do PVAl com a quitosana que ocorre de duas formas: As interações intermoleculares das hidroxilas do PVAl com as hidroxilas da quitosana e as interações intramoleculares entre os ésteres e as hidroxilas da quitosana, formando malhas tridimensionais reduzindo os espaços entre as cadeias poliméricas, diminuindo o intumescimento do sistema (Ngah, 2004). Observa-se que o intumescimento das membranas de PVAl/argila com quitosana foi de aproximadamente $60 \%$, 
enquanto o sistema PVAl/argila, mostrado na FIG. 41, sem quitosana apresenta um intumescimento de $200 \%$, aproximadamente três vezes maior.

E perceptível que a proporção de ligações cruzadas é um dos fatores mais importantes que afetam o intumescimento dos hidrogéis. Quanto mais combinações de ligações cruzadas maior quantidade de reticulação do hidrogel tornando a estrutura mais rígida. Consequentemente, o intumescimento será menor se comparado com o do mesmo hidrogel quando este apresenta menor razão de ligações cruzadas (PEPPAS, 2000).

Concernente à fração gel, a TAB.13 apresenta os resultados para o sistema PVAl/quitosana/argila.

TABELA 13 - Fração gel dos hidrogéis PVAl/quitosana/argila, obtidos por irradiação gama, dose de 25 kGy.

\begin{tabular}{ll}
\hline Membranas & Fração gel (\%) \\
& Média+desvio padrão \\
\hline PVAl/quitosana & $64 \pm 2$ \\
PVAl/quitosana/0,5\% argila & $61 \pm 1$ \\
PVAl/quitosana/1,0\% argila & $66 \pm 1$ \\
PVAl/quitosana/1,5\% argila & $71 \pm 1$ \\
\hline
\end{tabular}

Observa-se que a presença da quitosana contribuiu nesse sistema com valores de fração gel maiores comparando-se com o sistema PVAl/argila (TAB, 12). A proporção de ligações cruzadas é um dos fatores importantes para o aumento da fração gel das amostras dos hidrogéis Os resultados sugerem que a quitosana influenciou na reticulação da membrana. 


\subsection{Resultados dos hidrogéis obtidos de PVP/quitosana/argila - intumescimento e fração gel.}

Pode-se observar que os hidrogéis do sistema PVP/quitosana/argila apresentaram intumescimento com diferença significativa entre as porcentagens da argila, destacando-se maior intumescimento para a matriz PVP/quitosana/0,5\% argila, menor intumescimento para a matriz PVP/quitosana $/ 1,0 \%$ argila. $O$ comportamento foi semelhante entre PVP/quitosana/1,5 argila e PVP/quitosana sem argila após dez horas, conforme apresenta a FIG. 44.

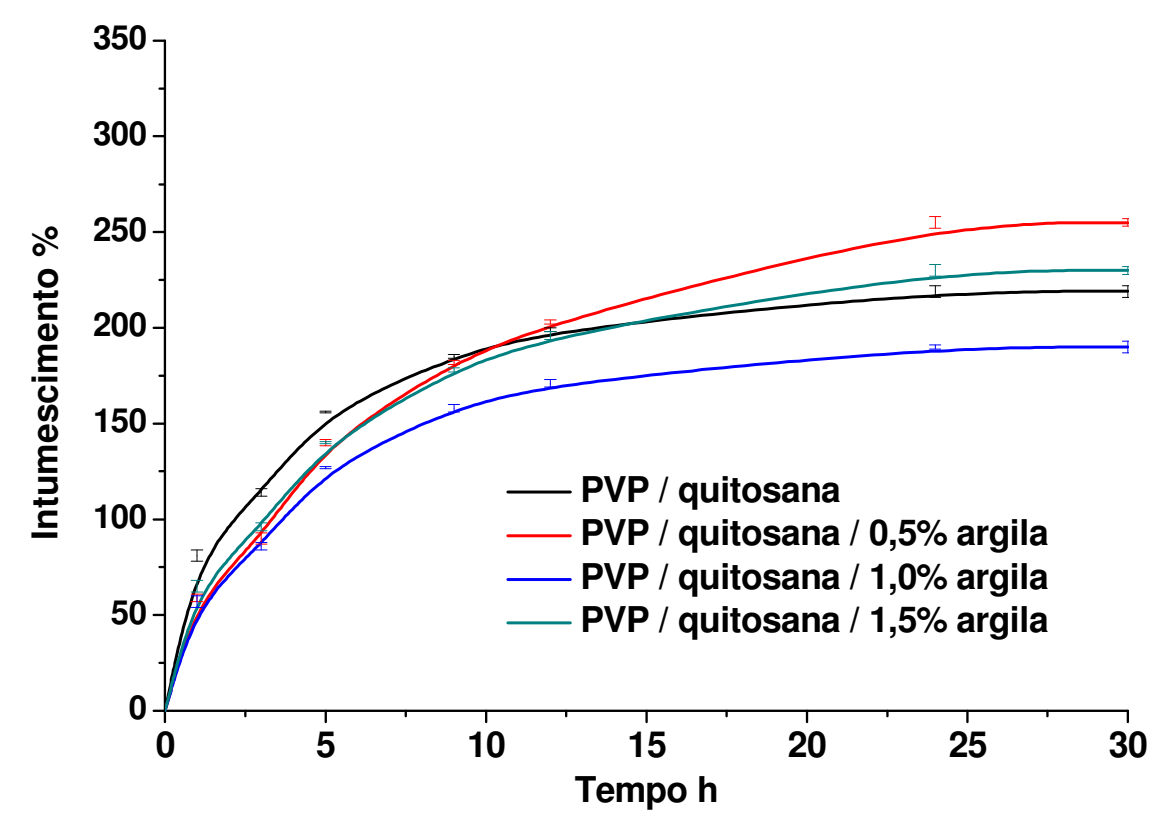

FIGURA 44 - Curvas de intumescimento das membranas de hidrogéis PVP/quitosana/argila, obtidos por irradiação gama, dose de 25 kGy.

Em todas as concentrações de argila o sistema das matrizes PVP/ argila sem quitosana apresentou intumescimento superior quando comparado ao do sistema contendo quitosana FIG. 44.

As interações PVP/quitosana/argila são favorecidas não somente pelas interações intramoleculares das hidroxilas com ésteres da quitosana, mas também pelas interações intermoleculares das hidroxilas da quitosana com grupos aminos do PVP, aumentando a reticulação do sistema apresentado. 
A TAB. 14 apresenta os valores da fração gel do sistema PVP/quitosana/argila e nota-se maior fração gel para a amostra com 1,0\% de argila.

TABELA 14 - Fração gel dos hidrogéis PVP/quitosana/argila, obtidos por irradiação gama, dose de 25 kGy.

\begin{tabular}{ll}
\hline Membranas & Fração gel (\%) \\
& Média+desvio padrão \\
\hline PVP/quitosana & $78 \pm 1$ \\
PVP/quitosana /0,5\% argila & $77 \pm 1$ \\
PVP/quitosana /1,0\% argila & $82 \pm 2$ \\
PVP/quitosana/1,5\% argila & $79 \pm 1$ \\
\hline
\end{tabular}

A presença da quitosana contribuiu aumentando a fração gel quando se compara ao sistema PVP/argila TAB. 12. O sistema PVP/quitosana/argila possui maior densidade de reticulação com pouca variação entre as porcentagens de argila analisadas, justificando-se ao efeito reticulante da quitosana. A fração de gel é parte insolúvel formada durante a reticulação por radicais livres como também pelas ligações intramoleculares da quitosana, com maior rearranjo das moléculas, bem como as interações da quitosana com o PVP nas ligações de hidrogênio, entre os grupos amida da quitosana com o grupo amino do PVP e as interações catiônicas de argila.

\subsection{Caracterização dos sistemas por termogravimetria (TG e DTG) e espectroscopia no infravermelho (FTIR)}

No sistema PVAI/PVP a decomposição dos nanocompósitos com argila apresenta três eventos. O primeiro que ocorre entre 195 a $222^{\circ} \mathrm{C}$, foi atribuído a perda de água para todas as amostras e desidroxilação do PVAI [Nair, 2007]. O 
segundo evento que ocorre entre 230 a $380{ }^{\circ} \mathrm{C}$ é associado a degradação do PVAl, enquanto que o terceiro entre 380 a $450{ }^{\circ} \mathrm{C}$, ocorre a decomposição das cadeias poliméricas do PVP principalmente, como mostram as FIG. 45 e FIG. 46.

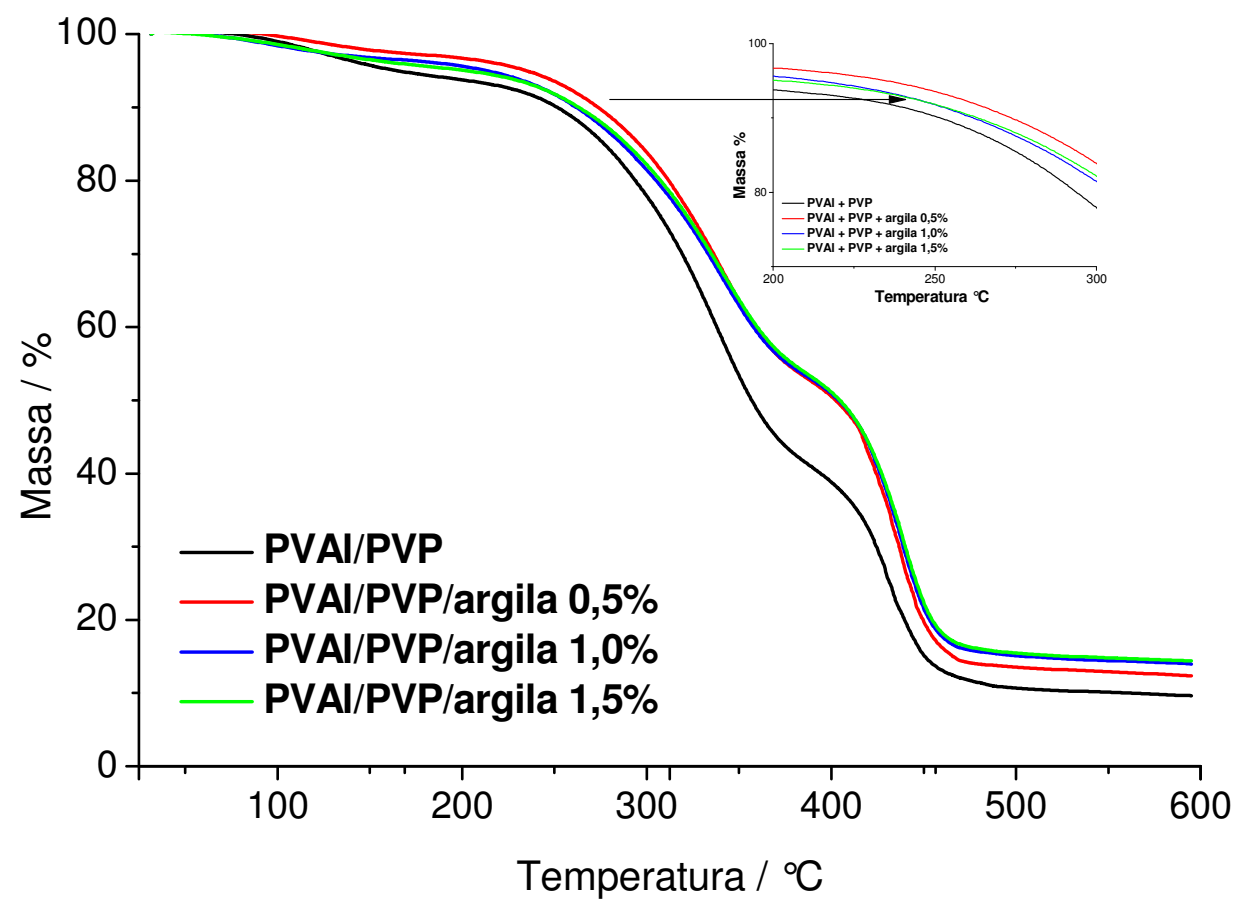

FIGURA 45 - Curvas de TG das membranas de hidrogéis PVP/PVAl/argila, obtidas por irradiação gama, dose de 25 kGy.

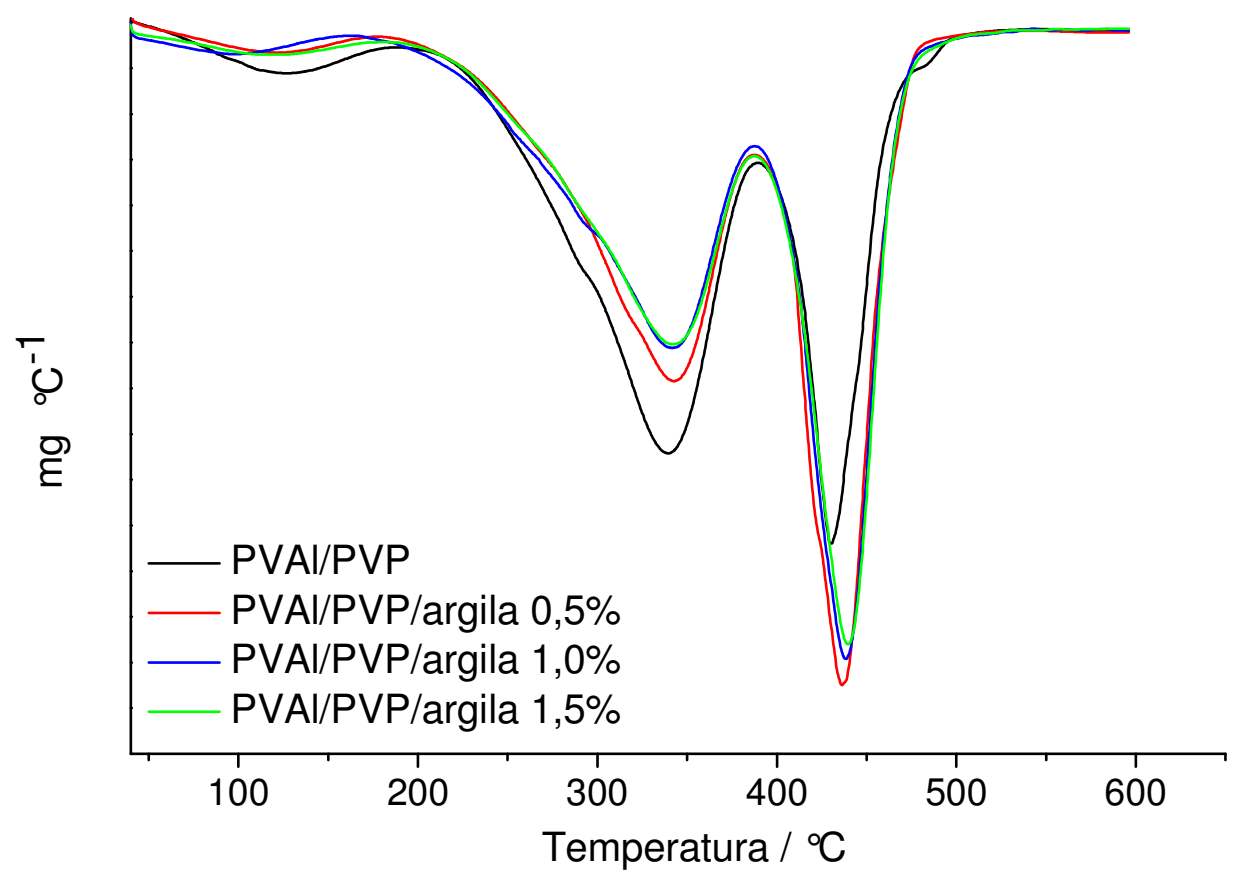

FIGURA 46 - Curvas de DTG das membranas de hidrogéis PVP/PVAl/argila, obtidos por irradiação gama, dose de 25 kGy. 
Para os hidrogéis obtidos com argila, há uma diferença no comportamento de decomposição térmica para o evento acima de $300^{\circ} \mathrm{C}$. Não se observa deslocamento de temperatura relacionado a interações entre o PVAl e a argila. O aumento de resíduo carbonáceo, da decomposição térmica, de 12 a 18\% demonstra a afinidade do polímero com a argila.

Enquanto a espectroscopia de infravermelho foi usada para verificar a identidade das várias estruturas de forma comparativa. Os principais picos de FTIR encontrados nos espectros das membranas de hidrogéis PVAI/PVP e argila estão descritos na TAB. 15.

TABELA 15 - Principais picos de infravermelho encontrados nas membranas de hidrogéis poliméricos PVAI/PVP e argila, $\delta=$ deformação e $\vee=$ estiramento.

\begin{tabular}{ll}
\hline Número de ondas $/ \mathrm{cm}^{-1}$ & Atribuição \\
\hline $3000-3500$ & $\vee$ O-H PVAl \\
1142 & $\delta \quad$ C-O PVAl \\
1666 & $v$ C=O PVP \\
1290 & $\delta$ C-N PVP \\
$600-550$ & $v$ N-C-O PVP \\
$1070-1095$ & $v$ C-O PVAl \\
966 & $\delta$ Si-O- Si \\
656 & $v$ Si-OH
\end{tabular}

$v=$ estiramento $\delta=$ deformação angular

Observa-se o pico largo na região de 3000 a $3500 \mathrm{~cm}^{-1}$ que está representado na FIG. 47, relativo ao estiramento do $\mathrm{OH}$ presente em todas as amostras. Atribui-se isso a uma grande distribuição de ligações de hidrogênio; os picos referentes aos hidrogéis apresentam intensidade semelhante nessa região e essa intensidade está relacionada com a quantidade de $\mathrm{OH}$ presente na amostra.

Nota-se que não houve mudanças significativas nos deslocamentos dos picos para esse sistema de PVAl/PVP/argila. 


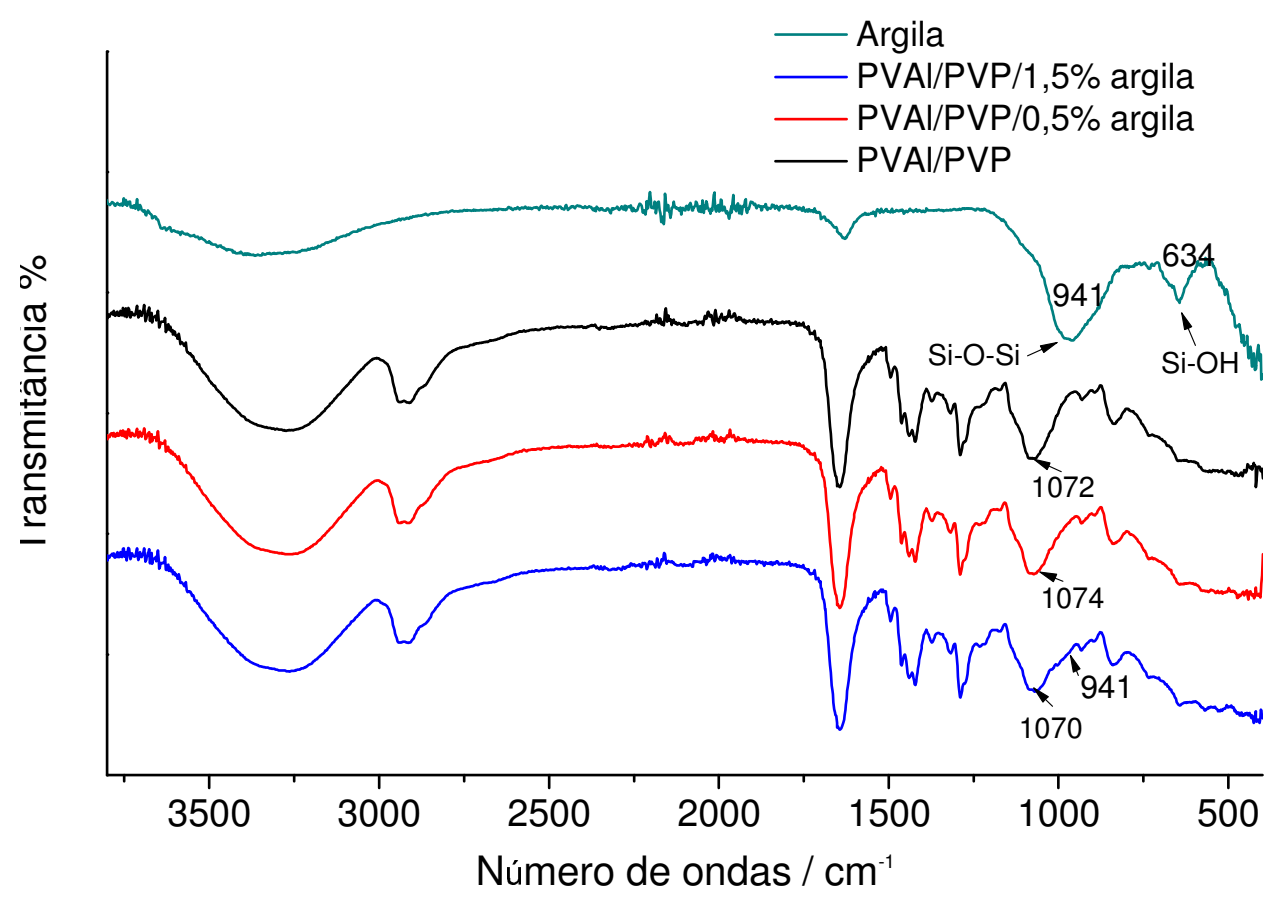

FIGURA 47 - Curvas de espectroscopia vibracional na região do infravermelho dos hidrogéis secos em forma de filmes PVAl/PVP/argila.

Para o sistema PVAl/argila os eventos de decomposição térmica foram identificados como: primeiro evento ocorre entre 25 e $150{ }^{\circ} \mathrm{C}$ e está associado à decomposição com perda de água do nanocompósito e a desidroxilação do PVAl, mostrado na FIG. 48 e 49, segundo evento principal que ocorre entre 250 e 450 C devido a decomposição do polímero.

Nota-se que as membranas de hidrogéis do sistema PVAl/argila apresentam uma pequena diferença de estabilidade térmica inicial e superior, de acordo com o aumento da porcentagem de argila adicionada. O PVAl tem uma forte tendência para formar ligações de hidrogênio com o silício, bem como outras espécies contendo grupos altamente eletronegativos. A argila laponite tem grupos hidroxila, que podem ajudar na adsorção de PVAl na superfície da argila. A adsorção de PVAI na superfície da argila laponite presume-se que ocorra por ligações de hidrogênio. Além da ligação de hidrogênio, as forças de interação de Van der Waals entre segmentos do polímero e a superfície da argila também desempenham um papel importante no processo de adsorção em geral. 


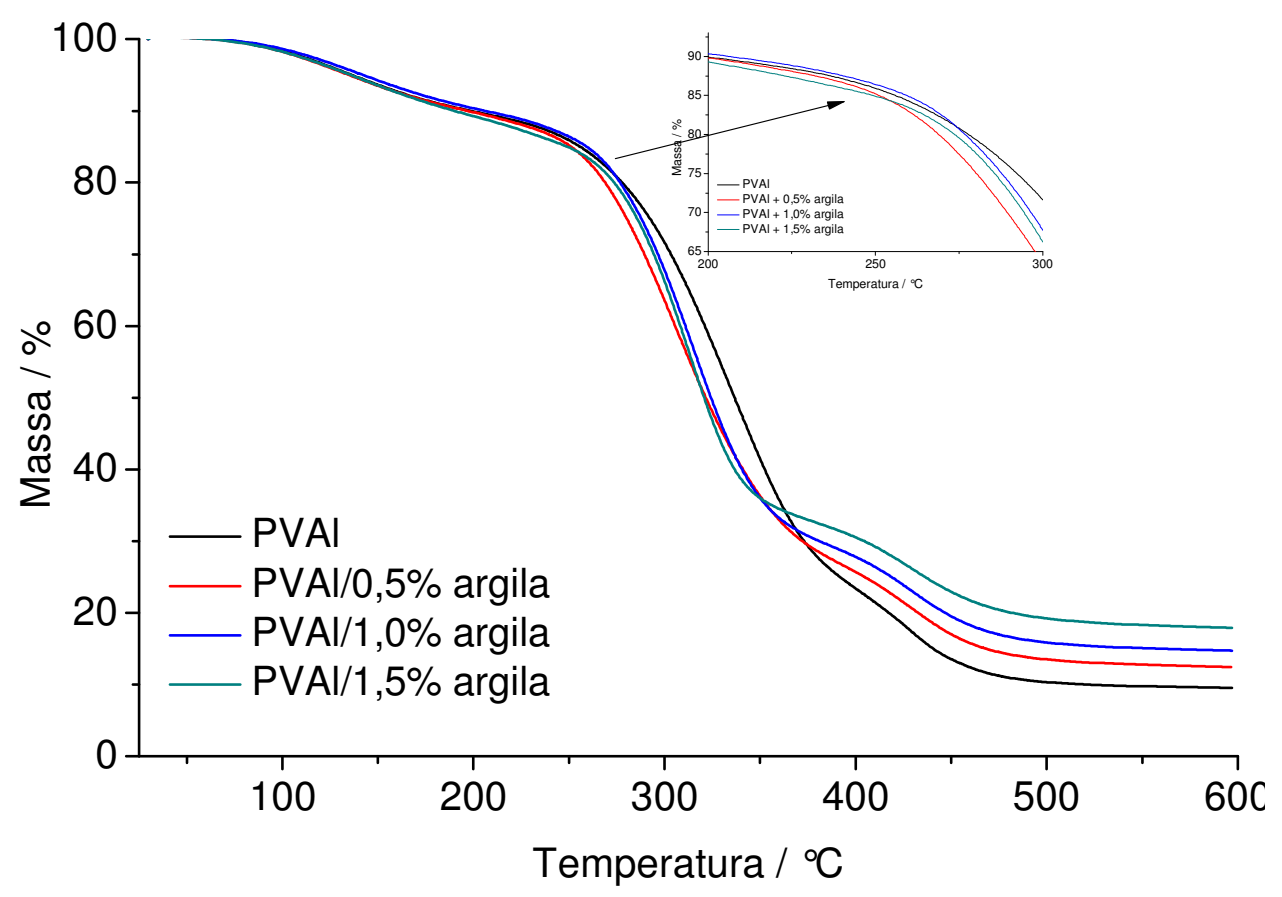

FIGURA 48 - Curvas de TG das membranas de hidrogéis PVAl/argila.

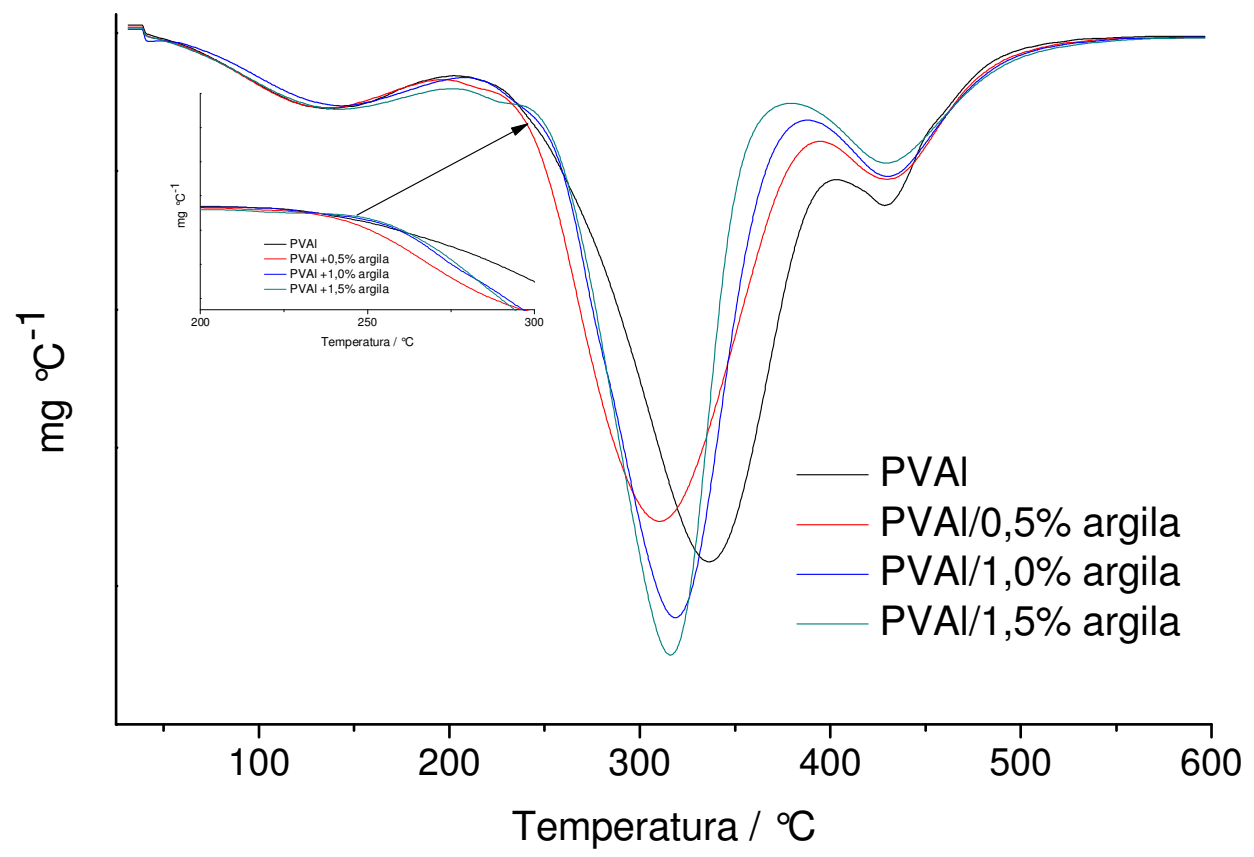

FIGURA 49 - Curvas de DTG das membranas de hidrogéis PVAl/argila.

O sistema PVP/argila apresenta um evento principal de decomposição de polímero acima de $380 \stackrel{\circ}{\circ}$, com sutil aumento de temperatura de 
decomposição em virtude da porcentagem da argila, mostrado nas FIG. 50 e FIG. 51.

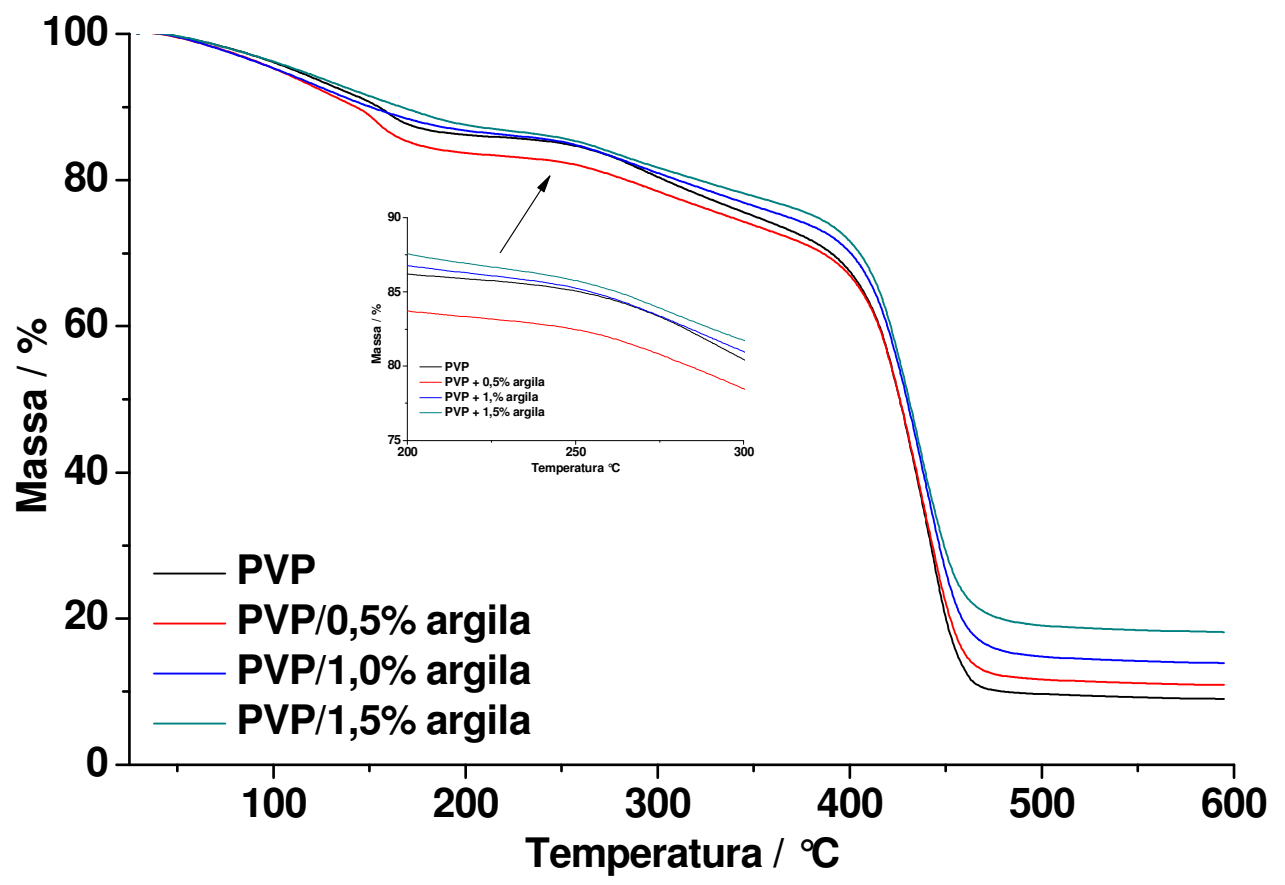

FIGURA 50 - Curvas de TG das membranas de hidrogéis PVP/argila.

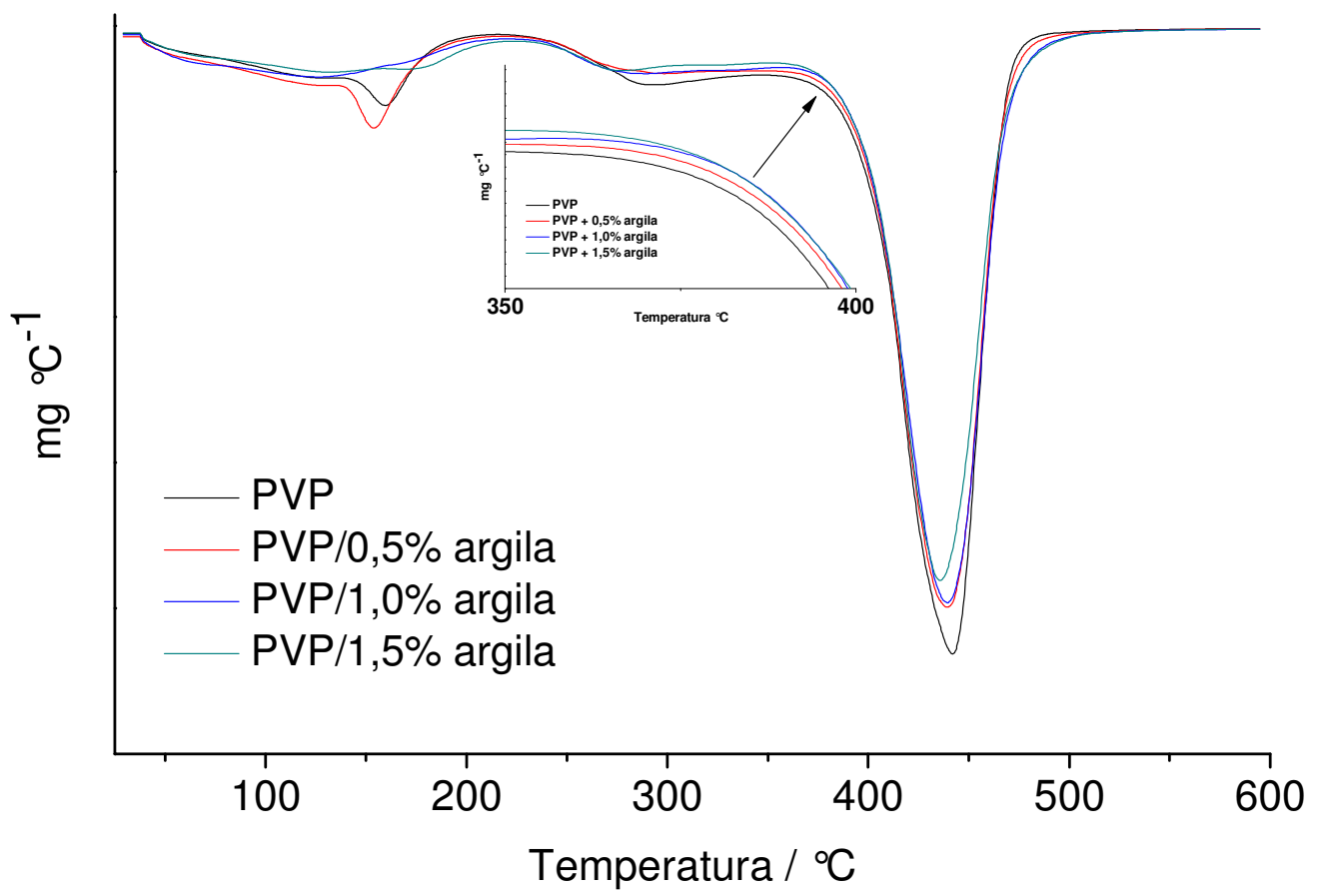

FIGURA 51 - Curvas de DTG das membranas de hidrogéis PVP/argila. 
Pode-se associar o aumento dos resíduos entre 9 e 18,5\% apresentados em ambos os sistemas a uma possível intercalação do polímero PVAl ou PVP na argila o que dificulta a decomposição da parte orgânica.

O sistema PVAl/argila apresenta no espectro de FTIR um deslocamento do estiramento CO de $1083 \mathrm{~cm}^{-1}$ para $1070 \mathrm{~cm}^{-1}$, que foi atribuído às interações do polímero na argila com a contribuição do grupo silanóis, como mostra a FIG. 52.

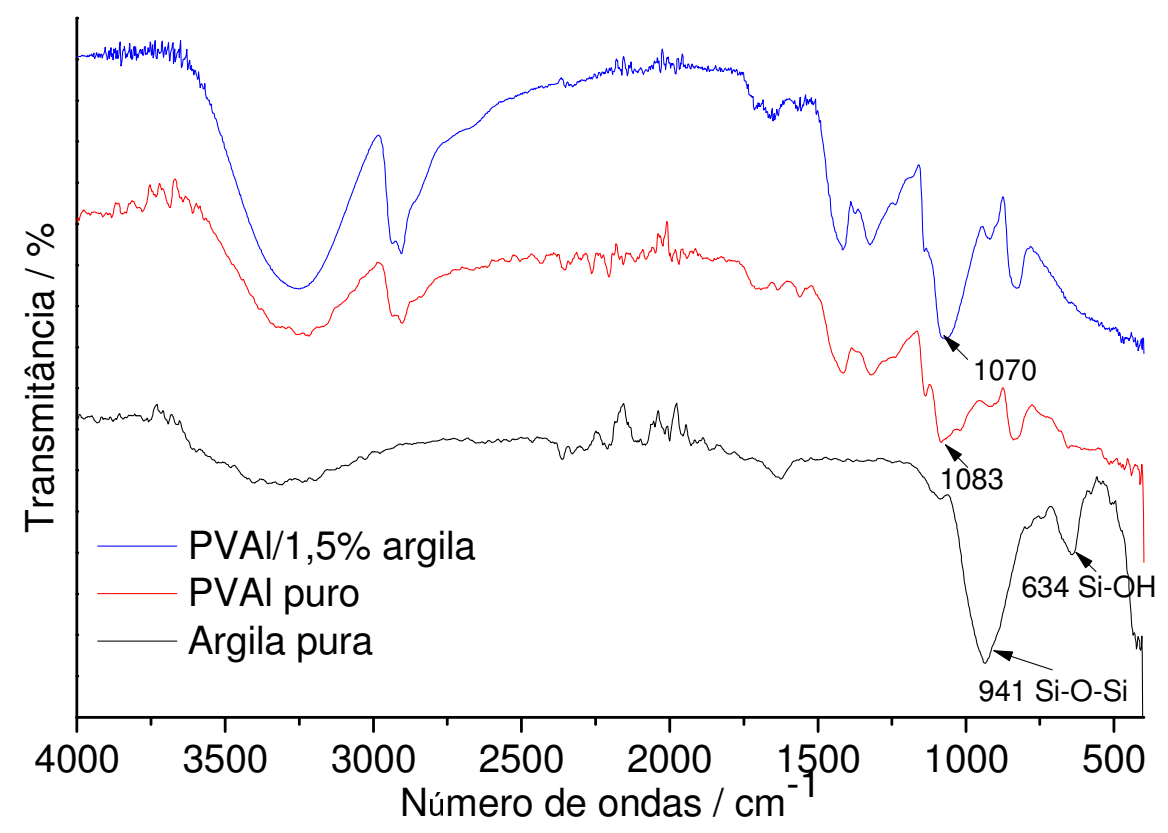

FIGURA 52 - Curvas de espectroscopia vibracional na região do infravermelho das membranas de hidrogéis secos em forma de filmes PVAl/argila.

Observa-se no sistema PVP/ argila o deslocamento do pico $\mathrm{CN}$ da região $1270 \mathrm{~cm}^{-1}$, para a região $1288 \mathrm{~cm}^{-1}$, que foi atribuído às interações do polímero na argila com a contribuição dos grupos silanóis, apresentados na FIG. 53. 


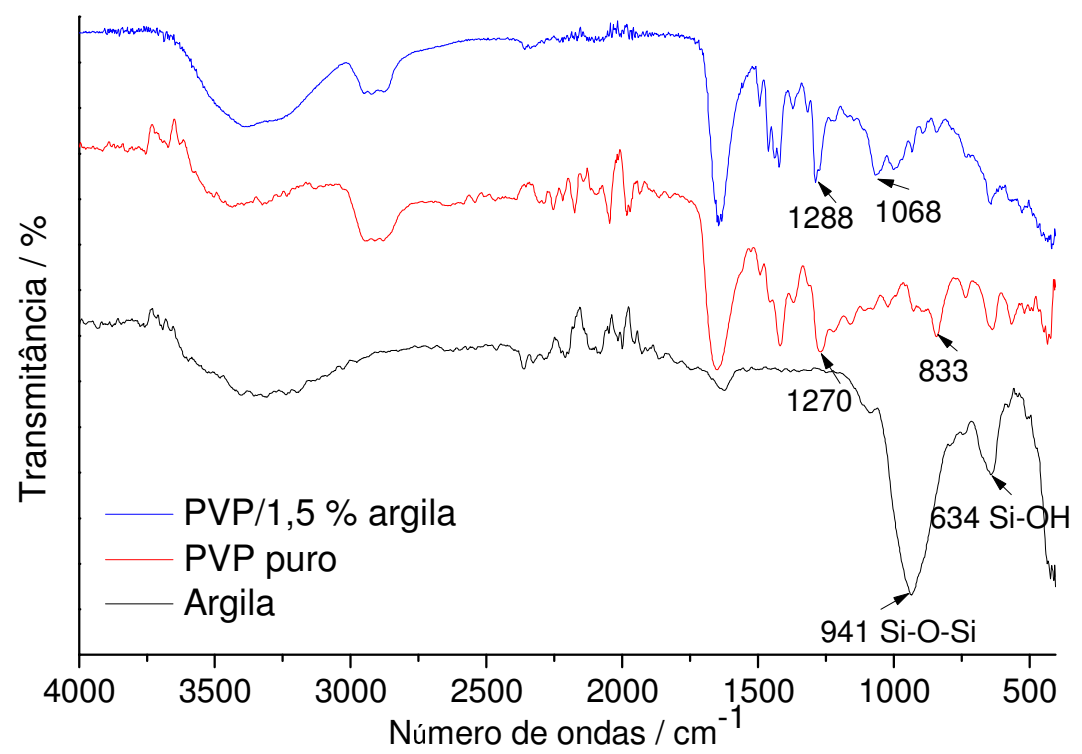

FIGURA 53 - Curvas de espectroscopia vibracional na região do infravermelho das membranas de hidrogéis secos em forma de filmes PVP/argila.

Para o sistema PVAl/quitosana/argila a estabilidade térmica dos polímeros pode ser avaliada por TG, em termos de decomposição com perda de massa, conforme resultados mostrados nas FIG. 54 e 55, respectivamente TG e DTG.

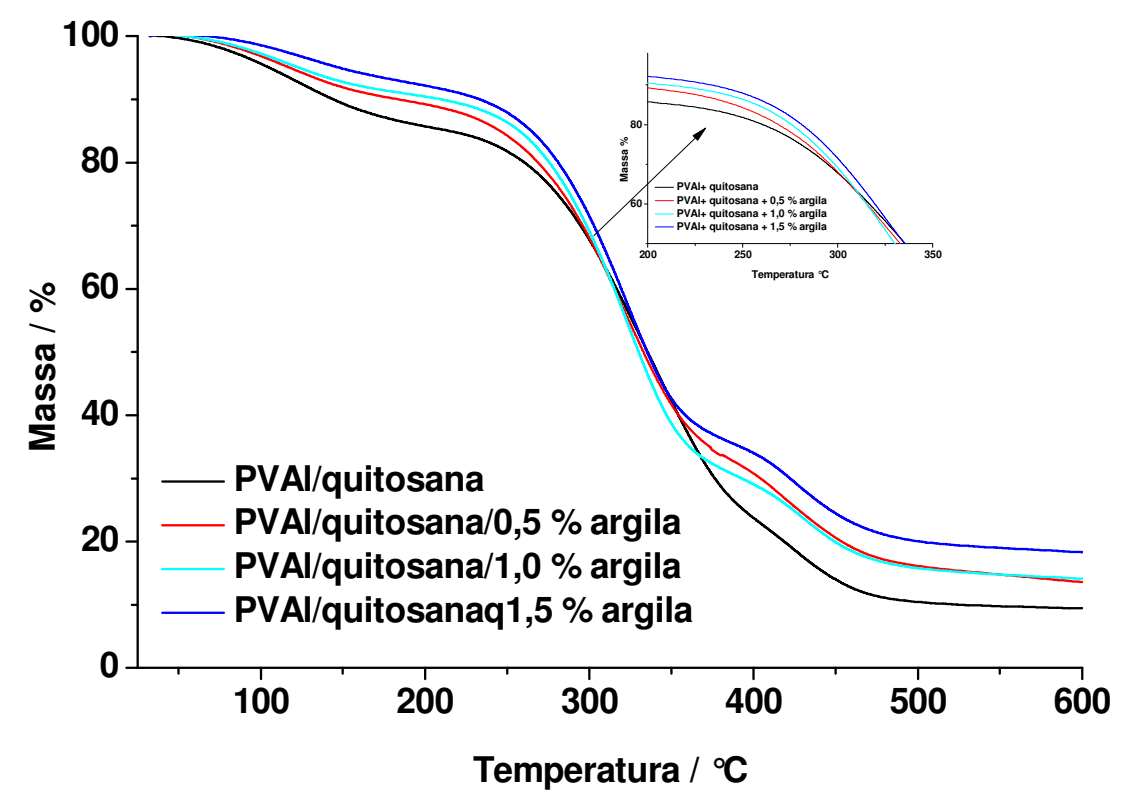

FIGURA 54 - Curvas de TG das membranas de hidrogéis PVAl/quitosana/argila. 


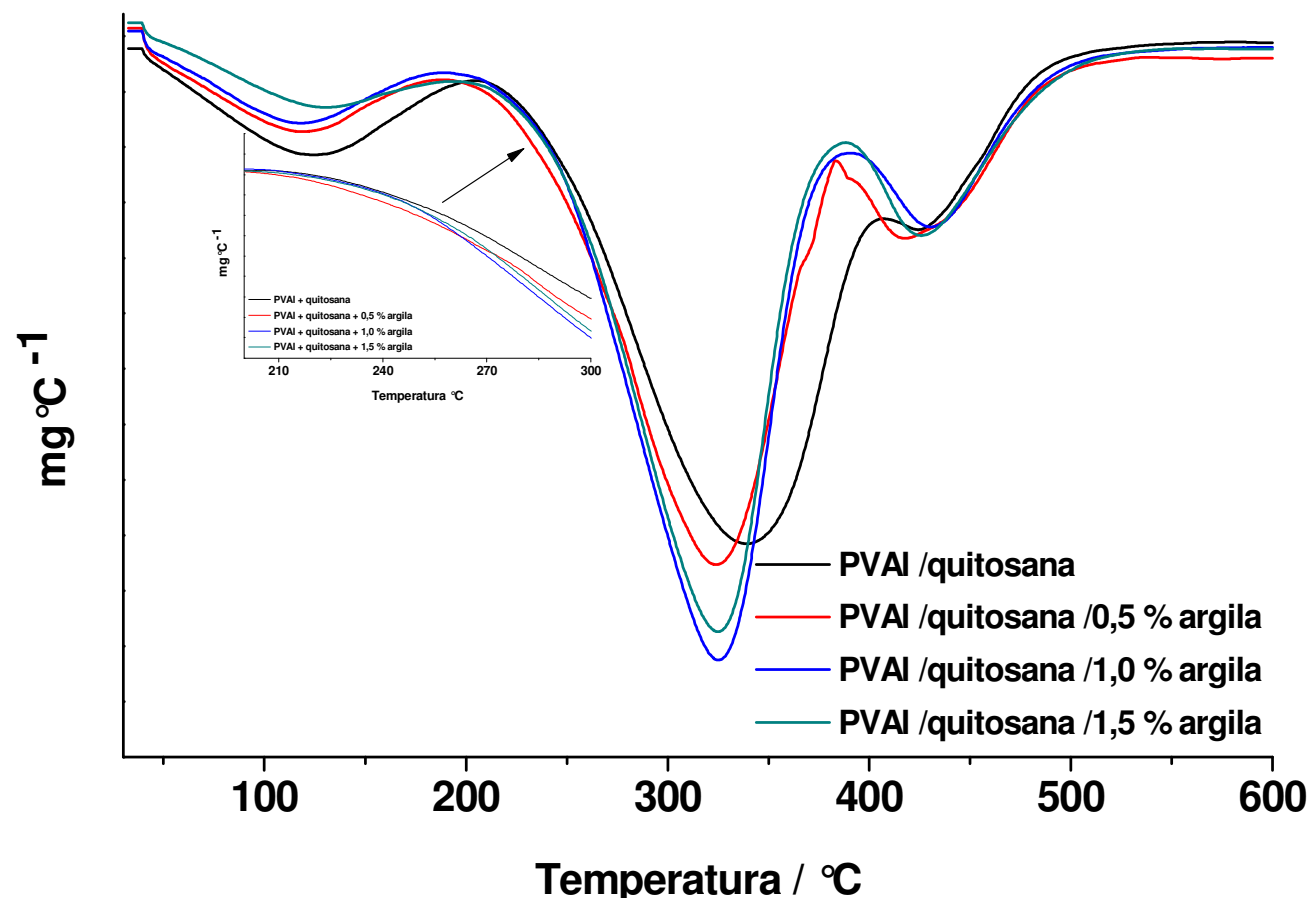

FIGURA 55 - Curvas de DTG das matrizes de hidrogéis PVAl/quitosana/argila, obtidos por radiação ionizante gama, dose de 25 kGy.

Observa-se que as curvas de TG apresentam três eventos. O primeiro evento é associado à perda de água do nanocompósito e dos produtos voláteis da quitosana. Também nessa temperatura acontece a desidroxilação do PVAI. O segundo evento de 200 a $380 \stackrel{\circ}{\circ}$ indica degradação das cadeias poliméricas inclusive as da quitosana; e o terceiro associado a produtos secundários derivados do PVAI. É perceptível o aumento da quantidade de resíduos com o aumento da porcentagem da argila, indicando que houve a interação ou enovelamento da argila com os polímeros. Neste sistema não se distinguiu o início de decomposição entre as diferentes concentrações de argila e de PVAl/quitosana.

O espectro de infravermelho apresenta um amplo pico de absorção em $3435 \mathrm{~cm}^{-1}$, que está associado ao estiramento $\mathrm{NH}$ da quitosana sobreposto ao estiramento OH do PVAl, de acordo com a FIG. 56. O pico do $\mathrm{C}-\mathrm{H}$ na região de $2942 \mathrm{~cm}^{-1}$ corresponde ao estiramento assimétrico e o pico de $2837 \mathrm{~cm}^{-1}$ ao estiramento simétrico. $\mathrm{O}$ pico característico da deformação angular do $\mathrm{CH}_{2}$ que aparece na região de $1079 \mathrm{~cm}^{-1}$, para o PVAl/quitosana, é deslocado para 1066 
quando se adiciona a argila indicando as possíveis interações da argila com o PVAl/quitosana.

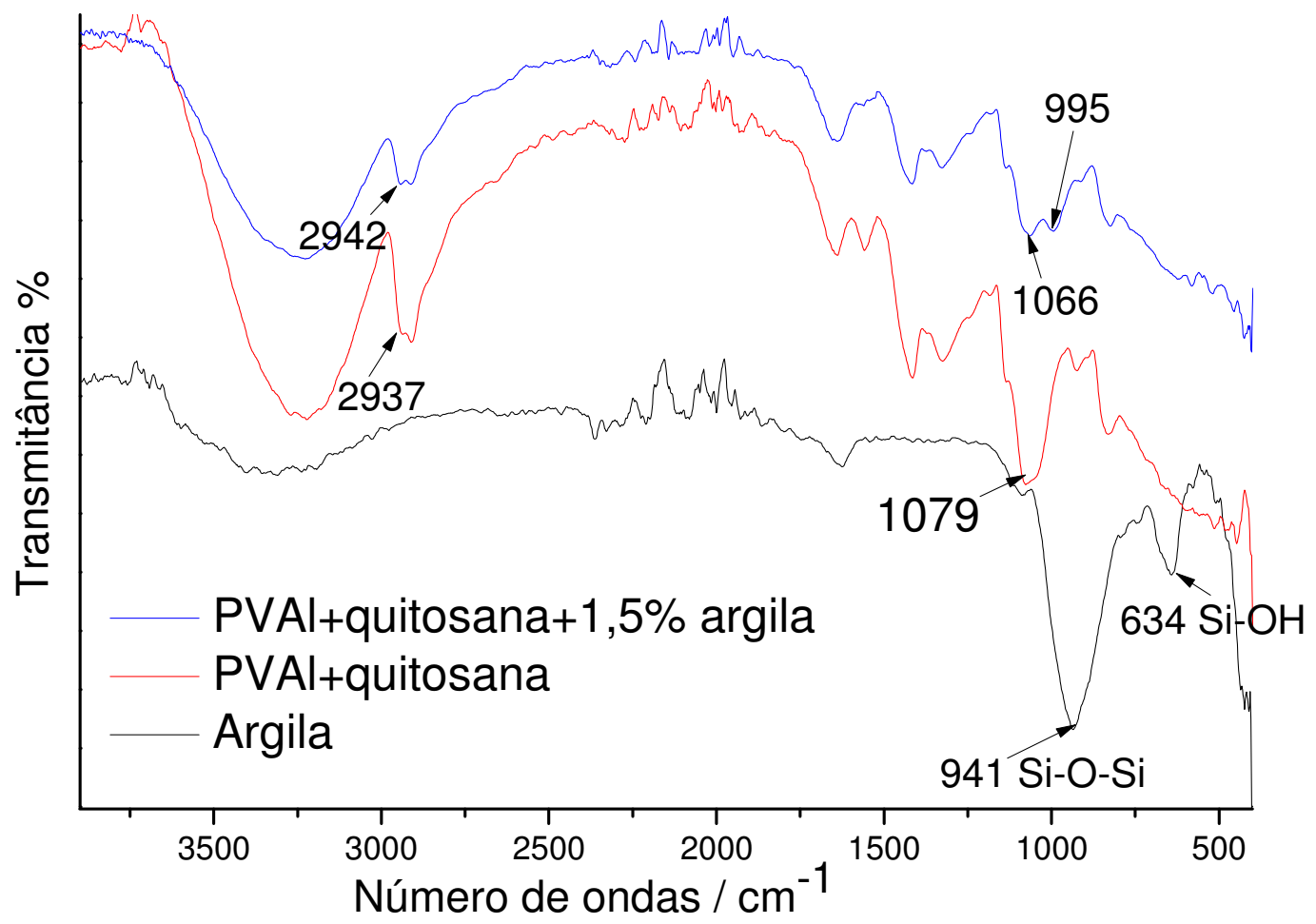

FIGURA 56 - Curvas de espectroscopia vibracional na região do infravermelho dos hidrogéis secos em forma de filmes PVAl/quitosana/argila.

No sistema PVP/quitosana resultaram as curvas de TG / DTG nas quais as amostras com 1,0\% e 1,5 \% argila demonstraram uma estabilidade relativa de início de decomposição provavelmente devido à interação com quitosana e argila, como mostram as FIG. 57 e FIG. 58, respectivamente de TG e DTG. O primeiro evento é associado a perda de água intercalada do nanocompósito e dos produtos voláteis da quitosana. O segundo evento entre 200 e $300^{\circ} \mathrm{C}$ se esperaria observar a decomposição da quitosana. Nas amostras de PVP/quitosana/argila 1,0 e 1,5\% praticamente desaparece o segundo evento 0 que é atribuído a reticulação PVP/quitosana. O evento principal entre 300 e $500^{\circ} \mathrm{C}$ está associado à decomposição das cadeias poliméricas. Os resíduos aumentam com a presença da argila o que indica que interação dificulta a decomposição do material carbonáceo. 


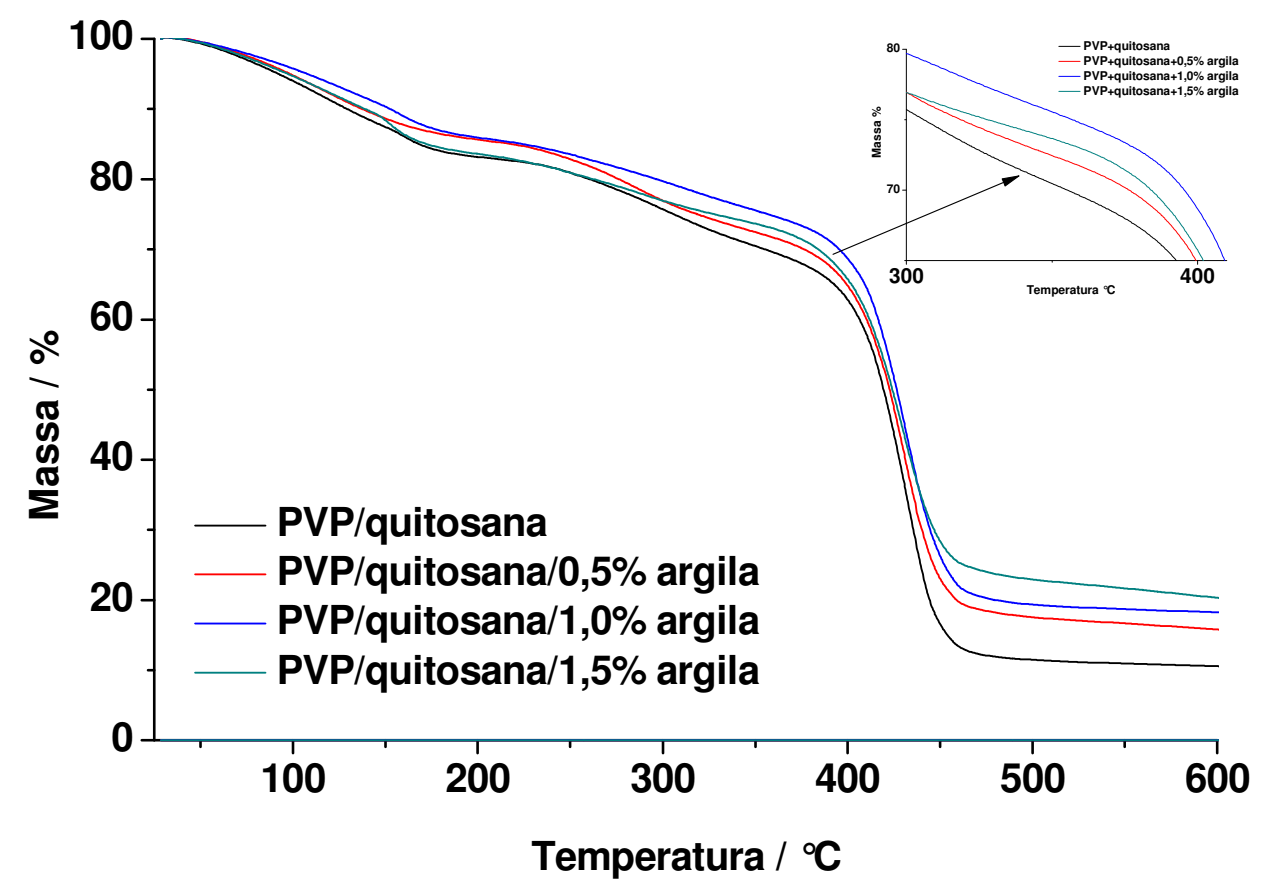

FIGURA 57 - Curvas de TG das membranas de hidrogéis PVP/quitosana/argila, obtidos por irradiação gama, dose de 25 kGy.

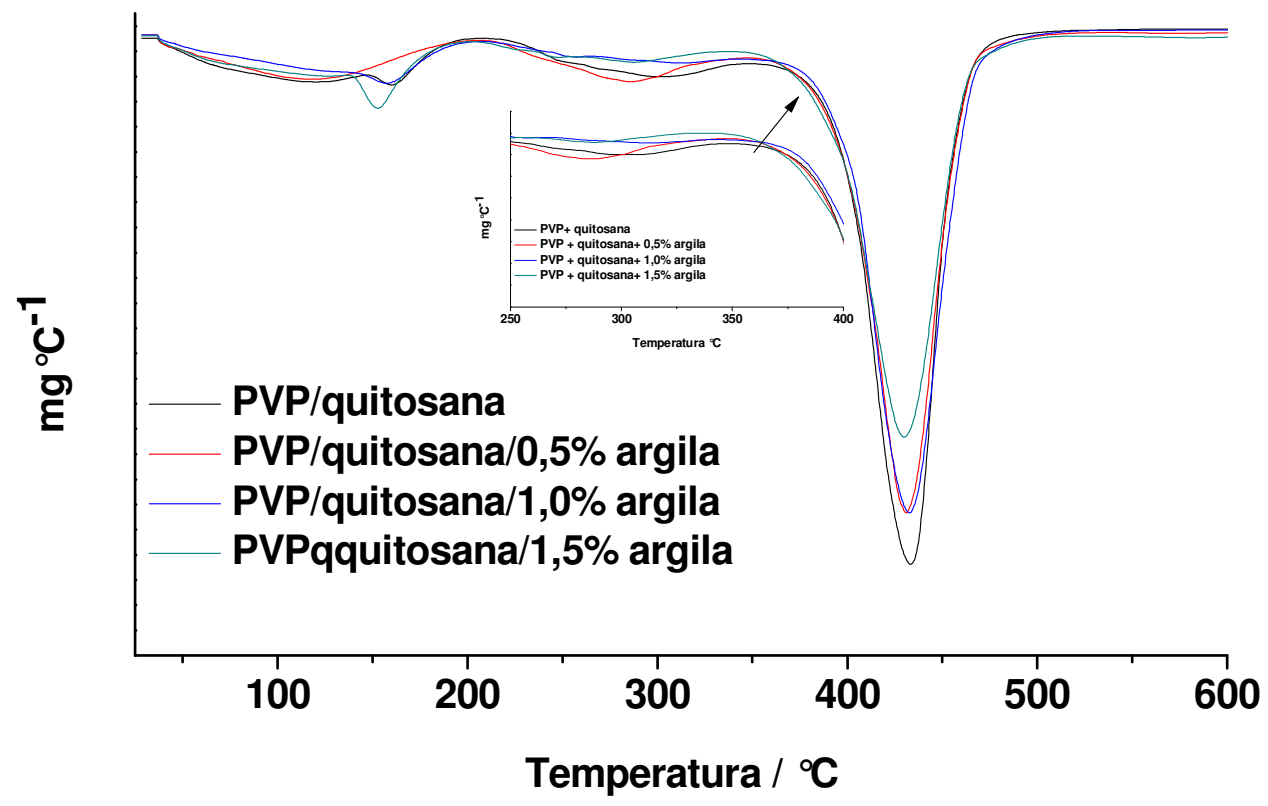

FIGURA 58 - Curvas de DTG das membranas de hidrogéis PVP/quitosana/argila, obtidos por irradiação gama, dose de $25 \mathrm{kGy}$. 
A FIG. 59 apresenta as curvas de espectroscopia vibracional na região do infravermelho para o sistema PVP/quitosana/argila.

As interações PVP/quitosana podem ocorrer de duas formas, tanto pelos radicais formados por reticulação gama, quanto por interações dos grupos hidroxilas e amina da quitosana por meio das ligações de hidrogênio, levando à miscibilidade. Observa-se na região $1066 \mathrm{~cm}^{-1}$ um pico característico de $\mathrm{CH}_{2}$ do PVP e um pico característico do Si-0-Si em $986 \mathrm{~cm}^{-1}$ (PVP/quitosana/1,5\% de argila). O pico observado a $1066 \mathrm{~cm}^{-1}$ pode ser atribuído a interações $\mathrm{PVP} / q u i t o s a n a$ como junção dos picos originais em 1072 e $1020 \mathrm{~cm}^{-1}$.

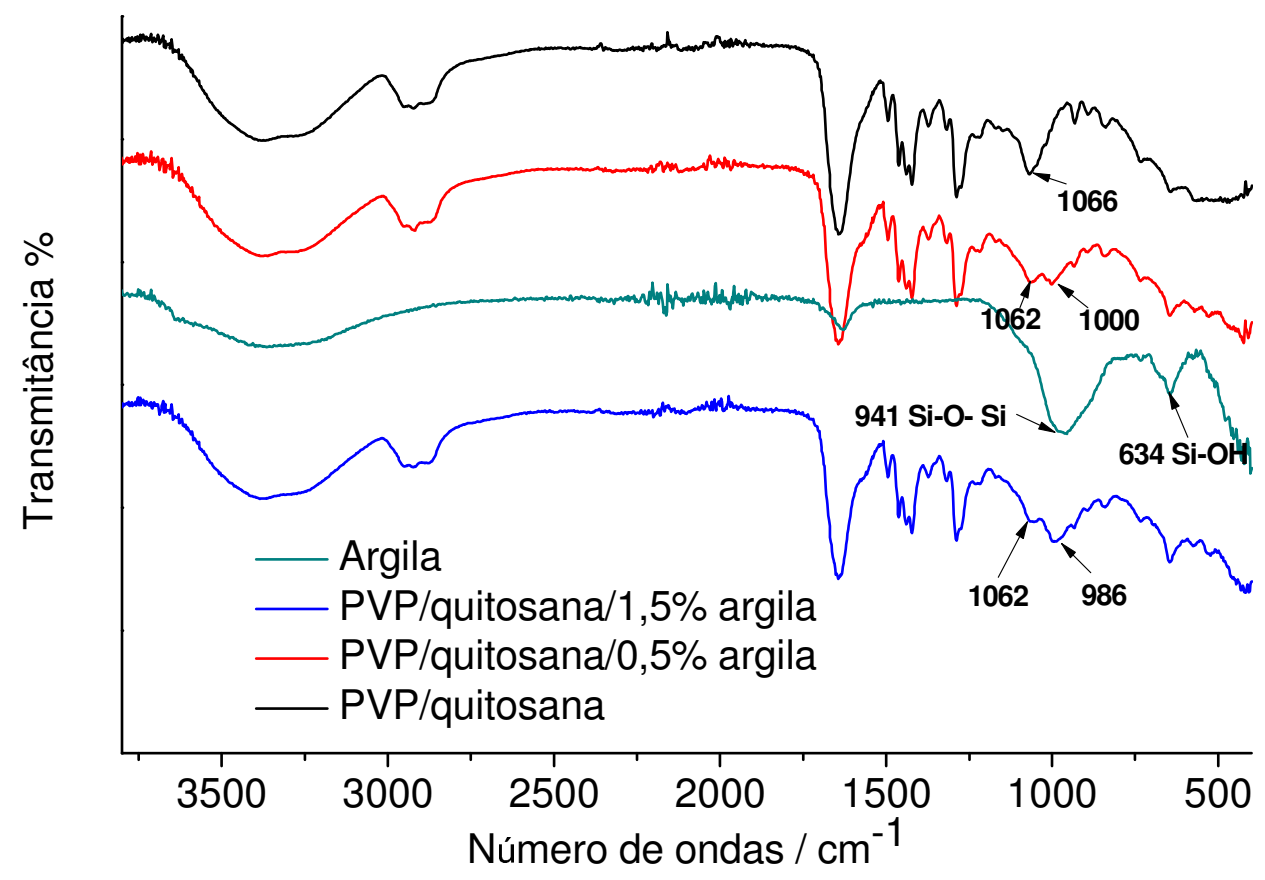

FIGURA 59 - Curvas de espectroscopia vibracional na região do infravermelho dos hidrogéis secos em forma de filmes PVP/quitosana/argila.

\subsection{Estudo da intercalação da argila nos sistemas por difração de raios $\mathrm{X}$}

Inicialmente, foi obtido o difratograma da nanopartícula pura para comparar a distância interlamelar inicial "d 001 " com a distância interlamelar "d" apresentada pelos compósitos experimentais. Por essa técnica foi possível avaliar o tipo de interações esfoliada ou intercalada da argila/polímero. 
O difratograma da argila laponita $R D$ indica um ângulo, referente ao plano $d_{001}$, de $2 \theta=6,3$ referente à distância interplanar de $d_{001}=13,9 \AA$. No sistema PVAl/PVP/argila observa-se predominância da esfoliação da argila pelo desaparecimento do pico atribuído a essa distância, conforme FIG. 60.

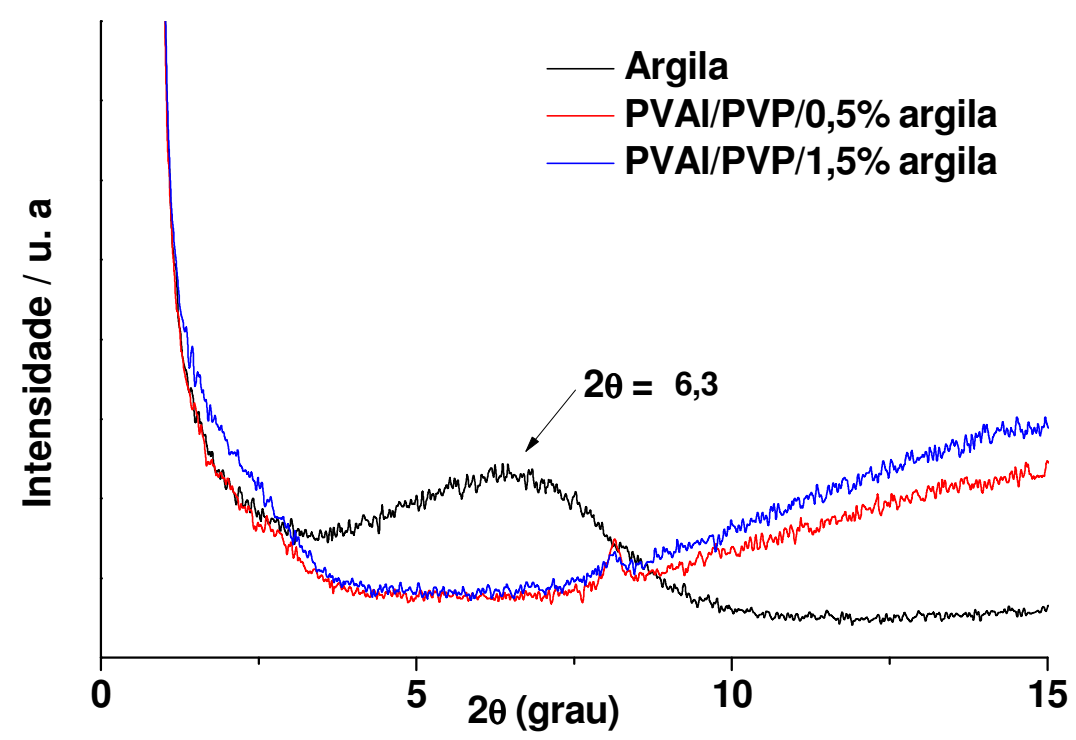

FIGURA 60- Curvas de DRX das membranas de hidrogéis de PVAl/PVP/argila.

Para o sistema PVA/argila cujo, difratograma dos nanocompósitos está representado na FIG. 61, apresenta também a predominância da esfoliação da argila pelo desaparecimento do sinal de $d_{001}$.

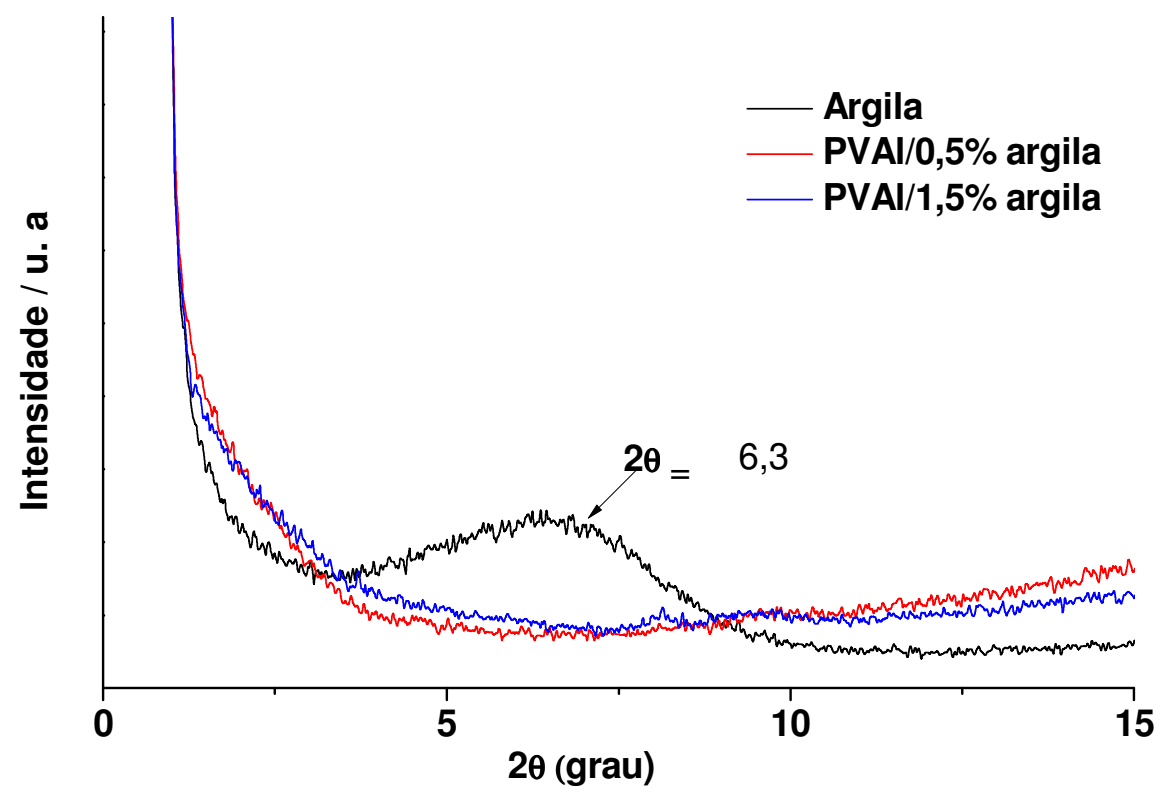

FIGURA 61 - Curvas de DRX das membranas dos hidrogéis de PVAl/argila. 
Para o sistema PVP/argila, a FIG. 62 apresenta os difratogramas dos nanocompósitos em comparação ao da argila. Observa-se o deslocamento do pico para ângulos menores PVP/0,5\% argila e 1,5\% argila para $2 \theta=2,2$ e $2 \theta=5,5$ respectivamente, relativos às distâncias interlamelares de 39,6 $\AA$ e de 17,6 como efeito de intercalação e esfoliação.

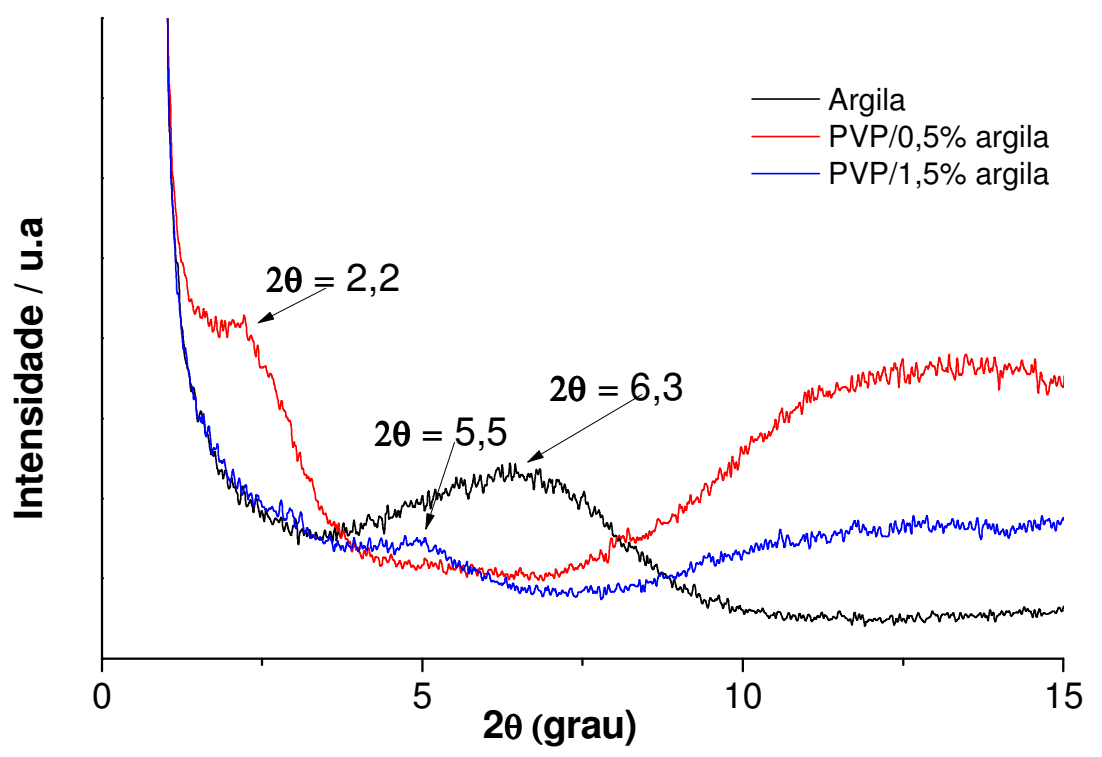

FIGURA 62 - Curvas de DRX das membranas dos hidrogéis de PVP/argila.

Com relação ao sistema PVAI/quitosana/argila, a FIG. 63 apresenta as curvas de DRX das membranas de hidrogéis de PVAl/quitosana/argila, onde não são observados picos $d_{001}$ para as duas concentrações de argila. 


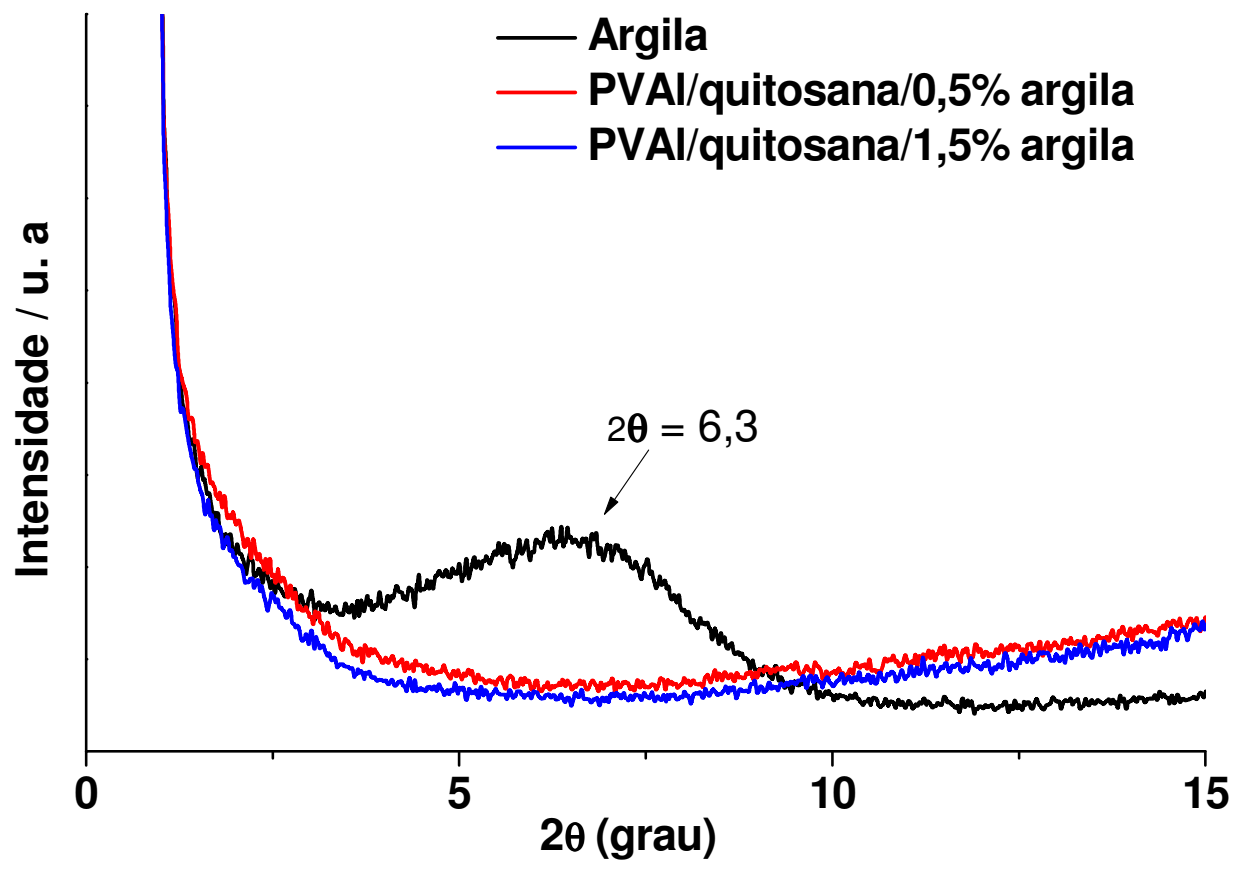

FIGURA 63 - Curvas de DRX das membranas de hidrogéis de PVAl/quitosana/ 1,0 e $1,5 \%$ argila.

Para o sistema PVP/quitosana/argila, ilustrado na FIG. 64, observa-se deslocamento do pico para um ângulo de $2 \theta=5,5$ da amostra com 1,5\% de argila aumentando a distância para $d=17,6 \AA$ comparando-se à distância $d=13,9 \AA$ da argila pura ocorrendo intercalação e esfoliação, enquanto a amostra com $0,5 \%$ apresenta-se a argila esfoliada, pela ausência do sinal difratograma.

As esmectitas e argilas similares como as laponitas possuem propriedades de troca catiônica, intercalação e inchamento que as tornam interessantes. Os cátions hidratados da superfície interlamelar podem ser substituídos por outros de interesse pelo método da troca iônica, a exemplo do íon de sódio na forma estrutural que se encontra na argila $\mathrm{Na}^{+0.7}\left[\left(\mathrm{Si}^{8} \mathrm{Mg}_{5.5} \mathrm{Li}_{0.3}\right) \mathrm{O}_{20}(\mathrm{OH})_{4}\right]^{-0.7}$. Moléculas neutras e orgânicas como polímeros também podem ser intercaladas entre as lamelas dessas argilas (Silva, 2008). 


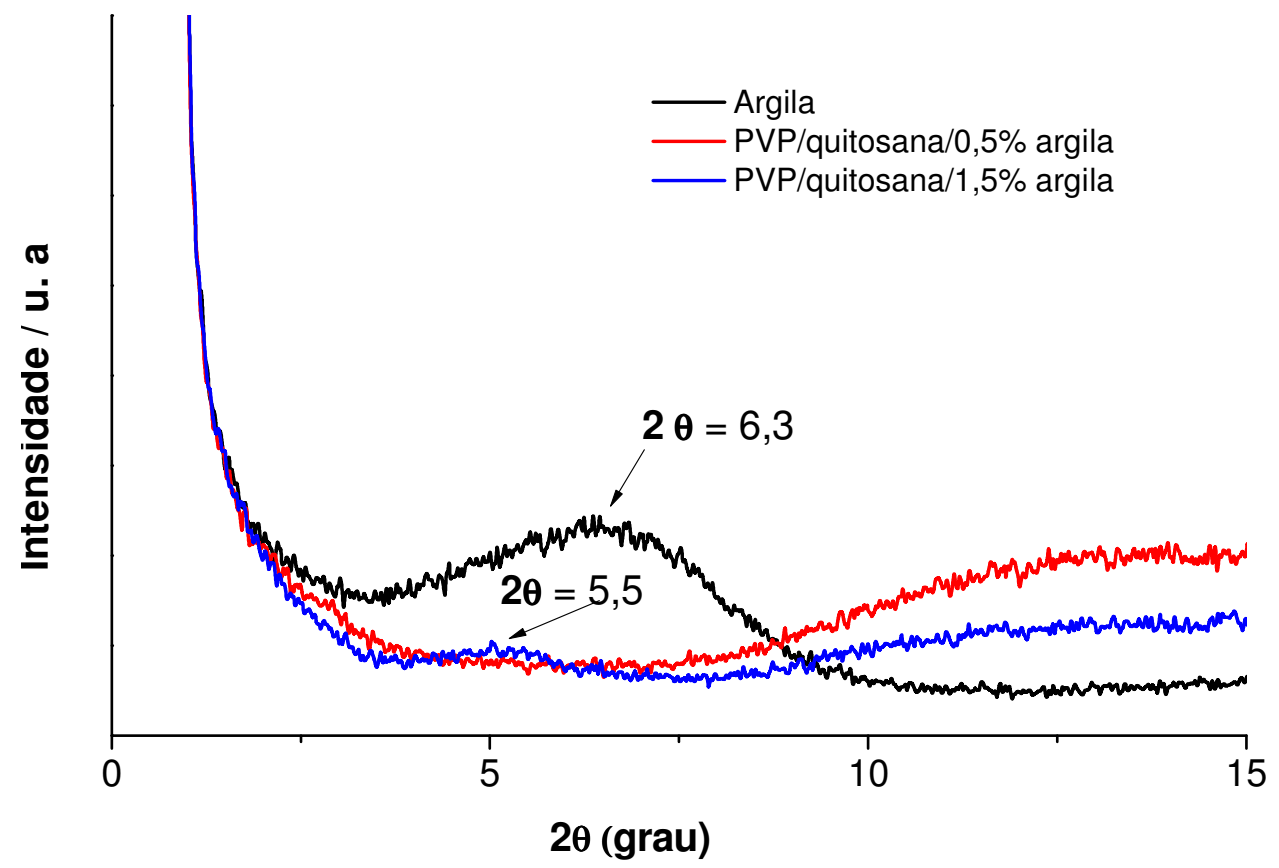

FIGURA 64 - Curvas de DRX das membranas de PVP/quitosana/argila.

A intercalação dos polímeros entre as camadas da argila contribui com a esfoliação e consequentemente com o desaparecimento do pico característico da argila. Muitos mecanismos podem operar no processo de intercalação, sendo que um mecanismo particularmente importante envolve a formação de complexos entre o cátion trocável e o cátion intercalante ou molécula intercalante.

É perceptível a diferença das interações da argila/polímero entre os sistemas apresentados. Observa-se nos sistemas apresentados por PVAl/PVP/argila e PVAl/argila que ocorreu esfoliação. Enquanto, os sistemas apresentados por PVP/argila ocorreu intercalação e esfoliação nas duas concentrações $0,5 \%$ argila e $1,5 \%$ argila.

Com a adição de quitosana observou-se que no sistema PVAl/ quitosana/argila ocorreu esfoliação para todas as concentrações de argila, enquanto que para o sistema PVP/quitosana/argila ocorreu esfoliação para a amostra com $0,5 \%$ de argila e intercalação e esfoliação para a amostra com 1,5\% de argila. Neste caso a presença da quitosana interferiu na interação da argila. 
5.7 Estudo da morfologia dos sistemas por microscopia eletrônica de varredura com emissão de campo (MEV-EC).

A micrografia da superfície de fratura da membrana de hidrogel PVAI/PVP liofilizada, apresenta macroporos e poros aleatórios, conforme a FIG. 65.

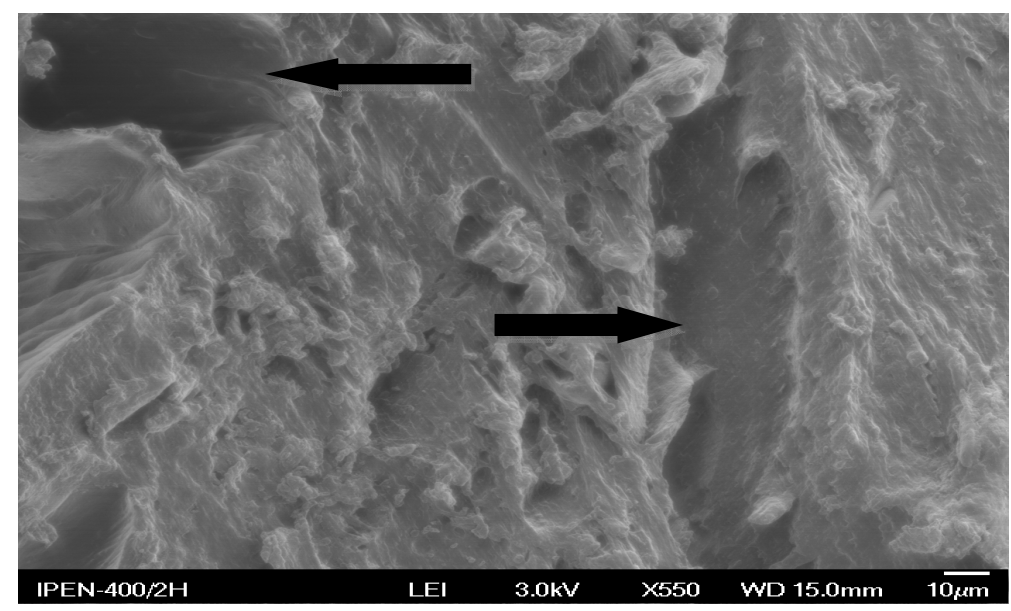

FIGURA 65- Micrografia de MEV da membrana de hidrogel liofilizado de PVAI/ PVP.

Por sua vez membrana PVAl/PVP com 1,0\% de argila apresenta poros menores e microporos mais organizados. Não foi possível verificar regiões com aglomeração da argila conforme a FIG. 66A. Já a micrografia da membrana de PVAI/PVP/1,5\% argila apresenta regiões com focos de aglomerações de nanopartículas de argila, FIG. 66B.
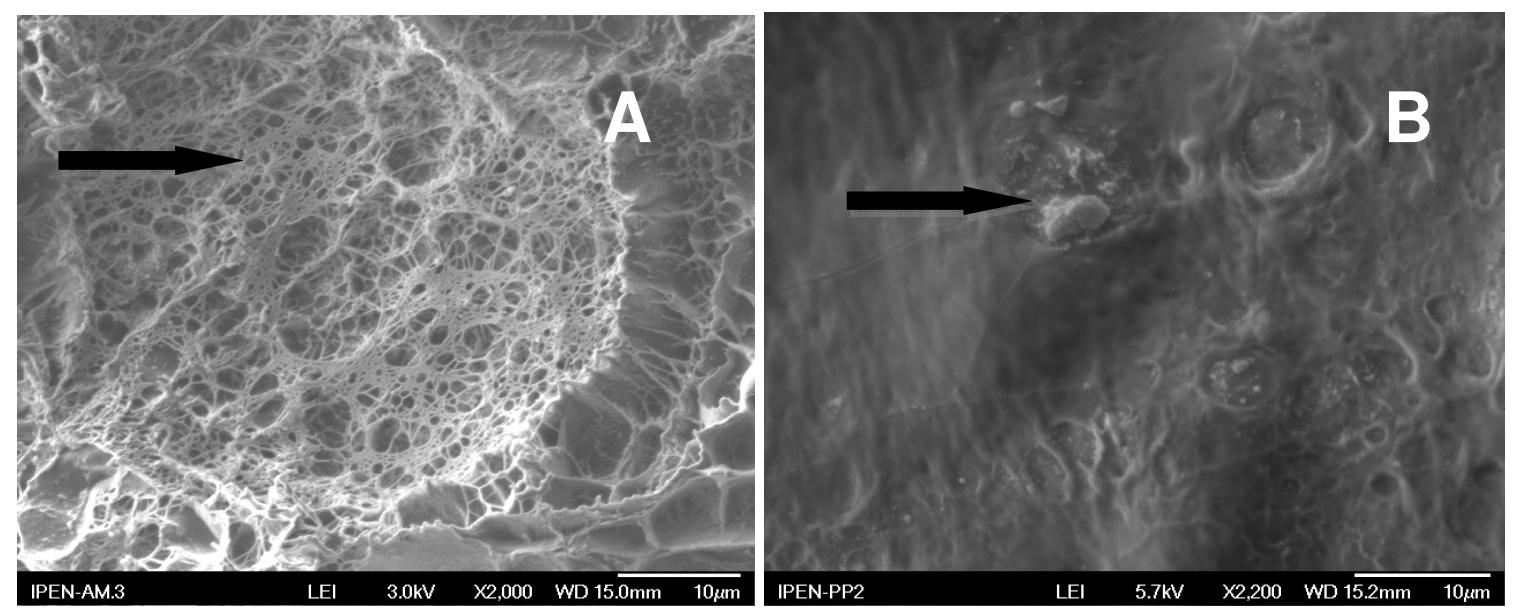

FIGURA 66 - Micrografia de MEV da membrana de hidrogel liofilizado (A) PVAl/ PVP $/ 1,0 \%$ de argila e (B) PVAl/PVP/1,5\% de argila 
Para o sistema PVAl/argila, as micrografias das superfícies de fraturas mostram imagens dos nanocompósitos onde se nota que a morfologia de PVAl/argila 1,0\% tem formato poroso, algumas regiões com macroporos maiores e desorganizados, enquanto o PVAl/ $1,5 \%$ argila apresenta regiões homogêneas com alguns pontos de aglomeração da argila na superfíce, apresentada na FIG. 67 ( $A$ e $B)$.
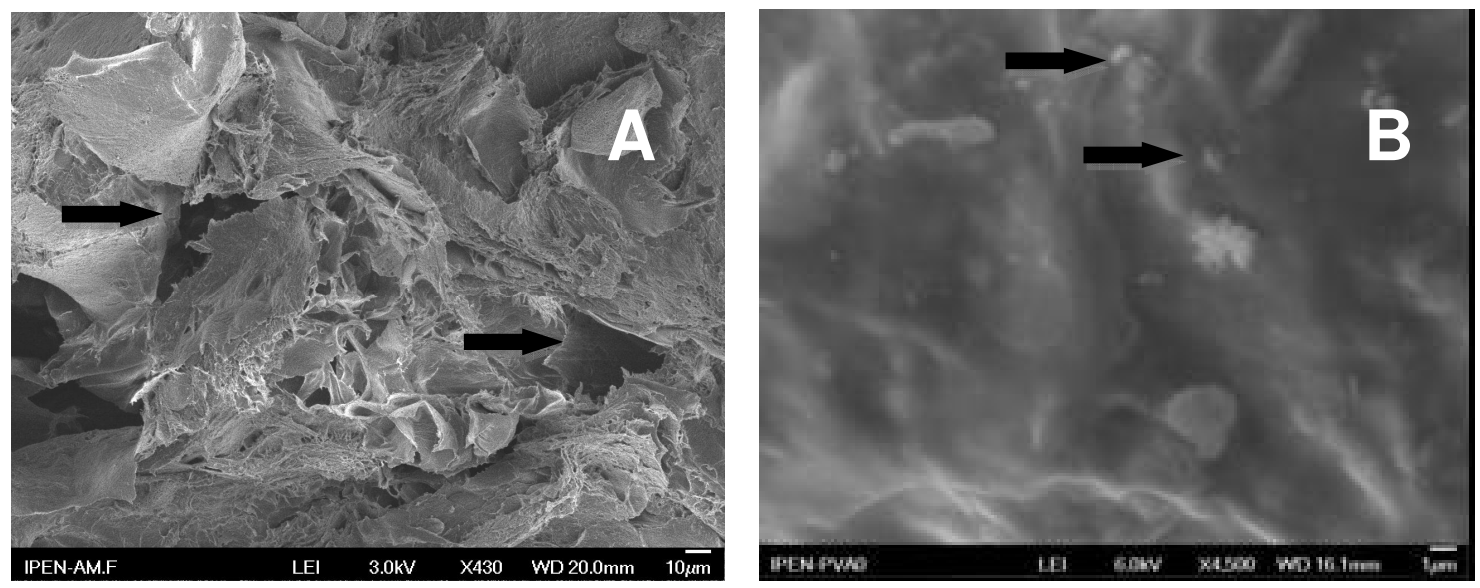

FIGURA 67 - Micrografias de MEV das membranas de hidrogéis liofilizados (A) PVAl $/ 1,0 \%$ argila e (B) PVAl $1,5 \%$ de argila.

No caso do sistema PVP/argila verifica-se uma morfologia da superfíce de fratura da amostra PVP/1,0\% argila com vários poros de formas aleatórias, enquanto que a amostra de PVP/1,5\% argila apresenta superfíce com macroporos e regiões com focos de aglomeração da argila, como mostra a FIG. $68(\mathrm{~A}$ e $\mathrm{B})$.
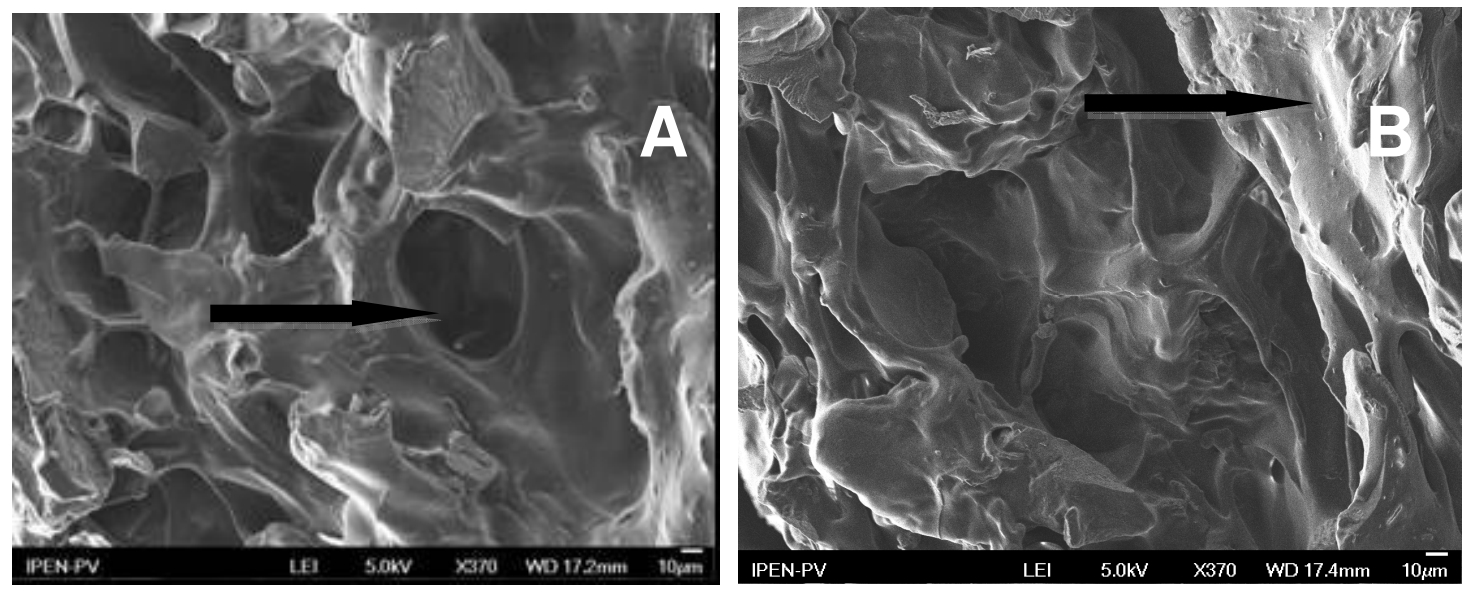

FIGURA 68 - Micrografias de MEV com emissão de campo (MV-EC) das membranas de hidrogéis liofilizados (A) PVP/1,0\% argila e (B) PVP/1,5\% argila. 
Para o sistema PVAl/quitosana/argila a FIG. 69 (A e B) apresenta as imagens das superfícies de fratruras das amostras PVAl/quitosana $/ 1,0 \%$ argila e PVAl/quitosana $/ 1,5 \%$ argila.
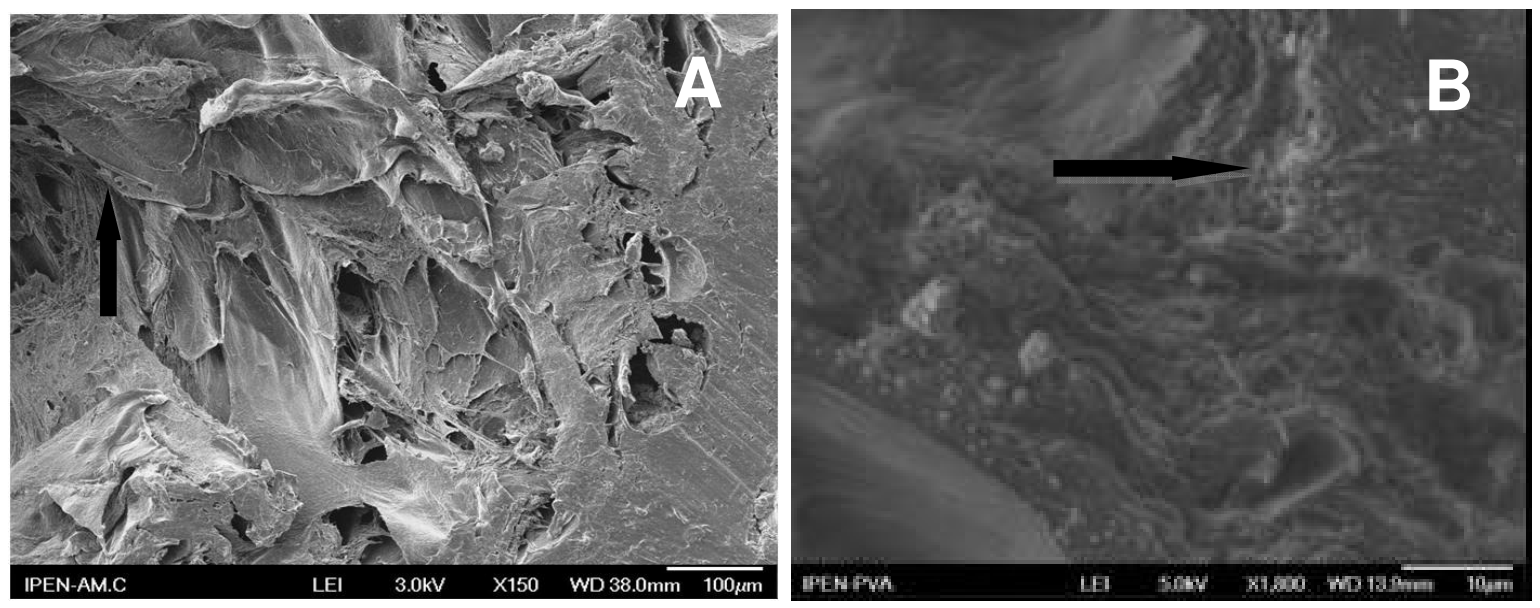

FIGURA 69 - Micrografias de MEV das membranas de hidrogéis liofilizados (A) PVAl/quitosana/1,0\% argila e (B) PVAl/quitosana/1,5\% argila.

Para o sistema PVP/quitosana/argila, a FIG. 70 (A e B) apresenta respectivamente as micrografias do sistema $\mathrm{PVP} /$ quitosana/1,0\% argila e PVP/ quitosana $/ 1,5 \%$ argila.
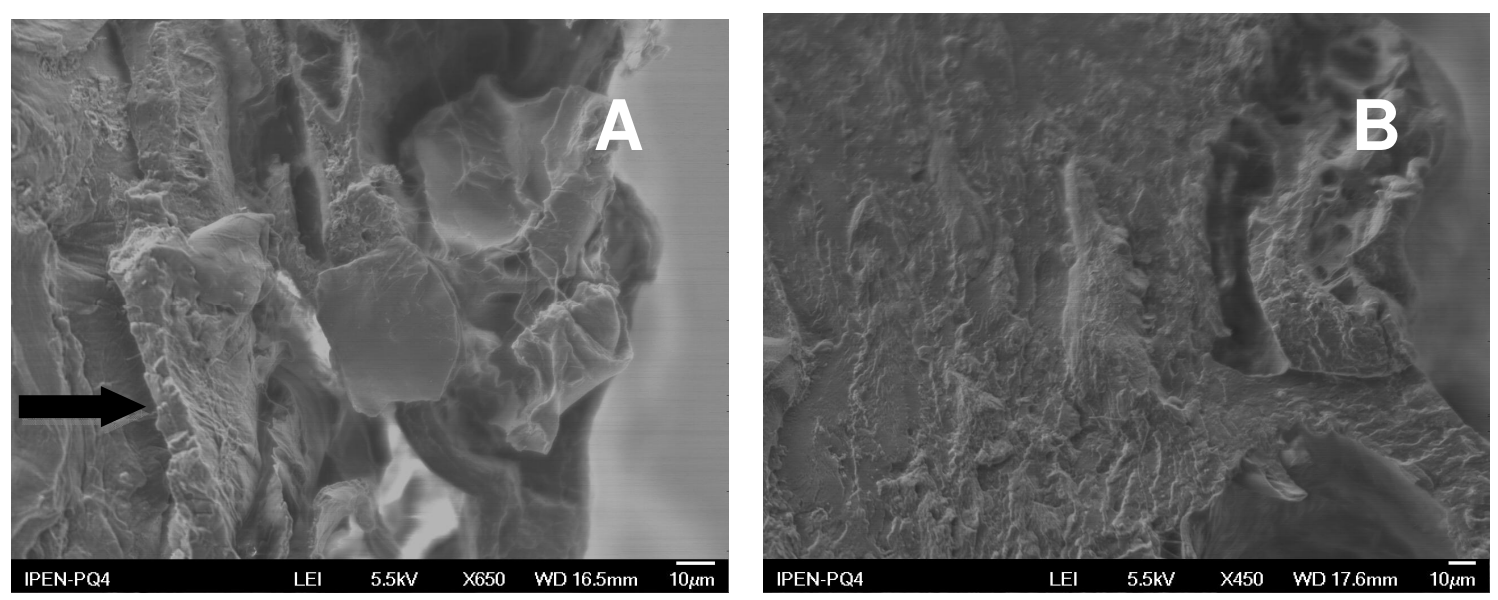

FIGURA 70 - Micrografias de MEV das membranas de hidrogéis liofilizados (A) PVP/quitosana/1,0\% argila e (B) PVP/quitosana/1,5\% argila.

Nota-se no sistema PVAl/quitosana/argila que a amostra com 1,0\% de argila apresenta-se morfologia irregular formando camadas. Quando existe um 
aumento da porcentagem da argila para 1,5\% observa-se a redução no tamanho dos poros.

A micrografia da superfície de fratura das amostras de PVP/quitosana/ $1,0 \%$ argila apresenta formato de placas irregulares com macroporos em toda superfície da amostra, FIG. 70A. Na amostra com 1,5\% de argila a superfície de fratura é homogênea sem rugosidade apresentando aglomeração da argila em algumas regiões, como se verifica na FIG. 70B. A quantidade de poros e macroporos observadas nas amostras são características dos hidrogéis liofilizados. Após a retirada da água por liofilização verifica-se a organização e formatos desses poros, formados durante o rearranjos das moléculas na reticulação.

\subsection{Estudo da macrodispersão da argila por espectrometria de energia dispersiva de raios $X$ EDS}

O estudo foi feito em membranas contendo $1,5 \%$ de argila e fármaco glucantime. No sistema PVAl/PVP/argila a partir da observação de composição da superfície de fratura das amostras, os elementos encontrados nas membranas liofilizadas referem-se a íons da argila $(\mathrm{Si}, \mathrm{Mg}, \mathrm{Na})$ e do glucantime (Sb).

As porcentagens de íons de sódio, magnésio, silício e antimônio foram observadas com distribuição homogênea na maior parte da amostra e estão representadas na FIG. 71. 

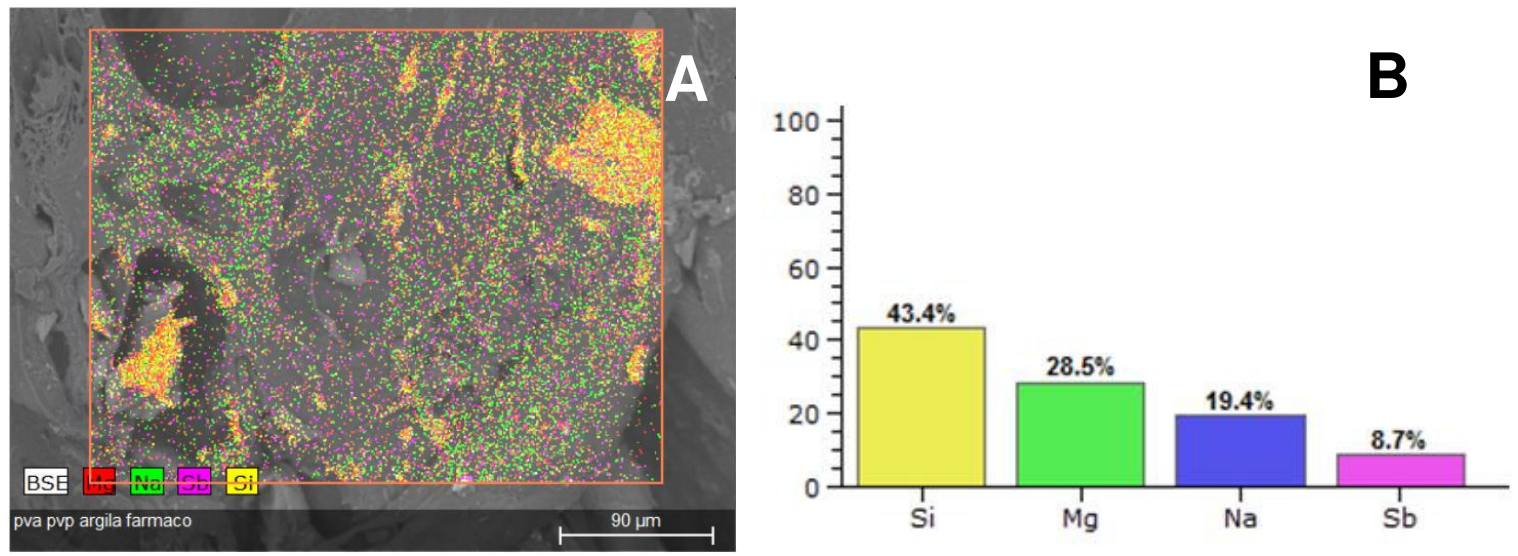

FIGURA 71 - (A) Micrografia de EDS e (B) gráfico com a porcentagem dos íons $\mathrm{Si}, \mathrm{Mg}, \mathrm{Sb}$ e $\mathrm{Na}$ dispersos na membrana de hidrogel de PVAl/PVP/argila 1,5\%.

Observa-se a identificação e quantificação dos elementos sódio, magnésio, silício e antimônio, com maiores aglomerações em algumas regiões da amostra. A distribuição do antimônio é homogênea na superfície de fratura de PVAI/PVP/argila 1,5\%

Referente aos sistemas PVAl/argila e PVP/argila têm-se as FIG. 72 e a FIG. 73 que mostra respectivamente as distribuições dos íons $\mathrm{Si}, \mathrm{Mg}, \mathrm{Sb}$ e $\mathrm{Na}$ nas superfícies de fratura das amostras dos sistemas.
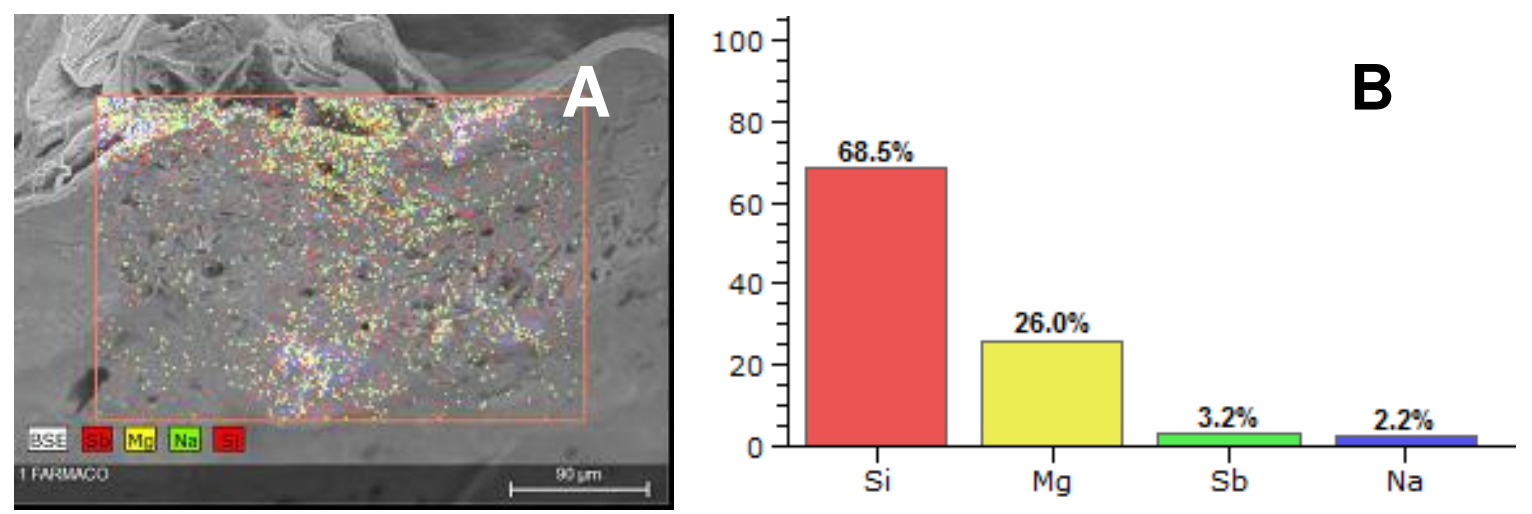

FIGURA 72 - (A) Micrografia de EDS e (B) gráfico com a porcentagem dos íons $\mathrm{Si}, \mathrm{Mg}, \mathrm{Sb}$ e $\mathrm{Na}$ dispersos na membrana de hidrogel de PVAl/0,5\% argila. 

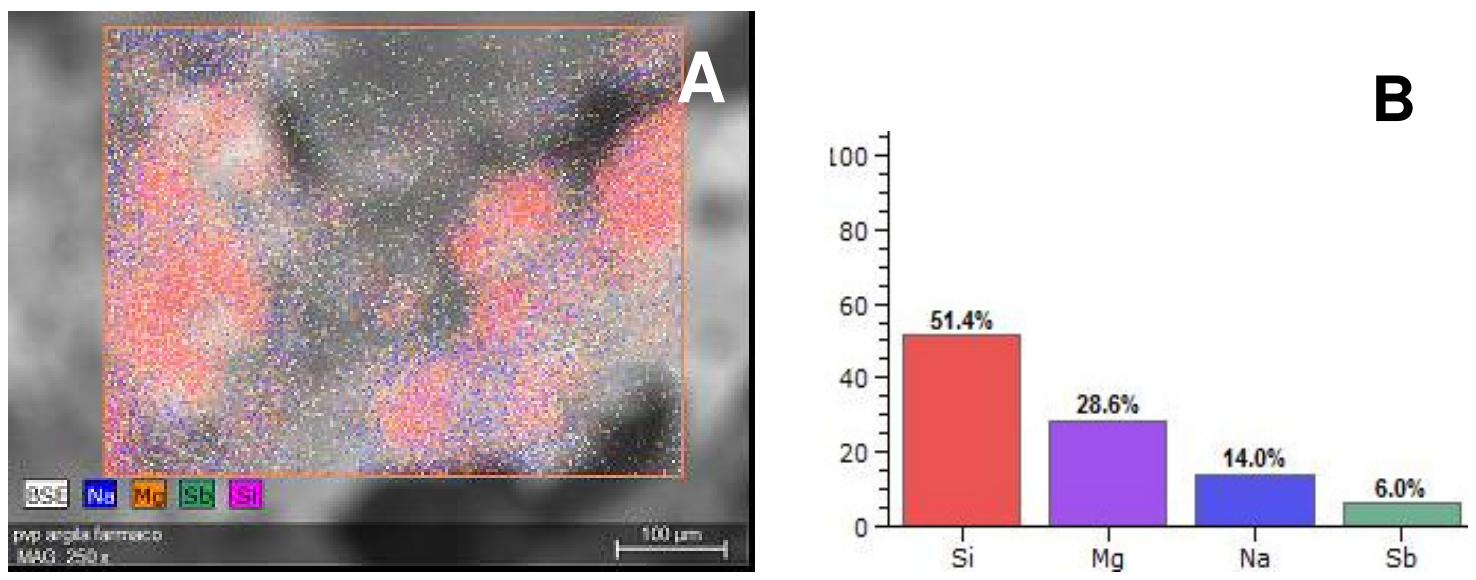

FIGURA 73 - (A) Micrografia de EDS e (B) gráfico com a porcentagem dos íons $\mathrm{Si}, \mathrm{Mg}$, Sb e Na em membrana de hidrogel de PVP/1,5\% argila.

Observa-se a distribuição dos íons inorgânicos na superfície de fratura da amostra de $\mathrm{PVAl} / 1,5 \%$ argila, onde há regiões com maiores concentrações para o Si e o Mg. Já o sistema PVP/1,5\% argila mostra maiores concentrações dos íons com aglomerações em grande parte da superfície de fratura da amostra. O que diferencia ambos os sistemas é a quantidade e a distribuição dos íons inorgânicos de acordo com as interações da argila na amostra. Tanto para a amostra PVAl/1,5\% argila quanto para o do PVP/1,5\% argila, é possível identificar uma distribuição homogênea do antimônio.

Para o sistema PVAl/quitosana/argila a micrografia de EDS é representada no gráfico da FIG. 74 com a porcentagem dos íons $\mathrm{Si}, \mathrm{Mg}$, Sb e Na dispersos homogeneamente na membrana de hidrogel de PVAl/ quitosana/1,5\% argila. Como o silício é a base dos silicatos (argilas) a sua porcentagem é maior em toda área da amostra. $\mathrm{O}$ antimônio também possui distribuição homogênea nesta amostra. 

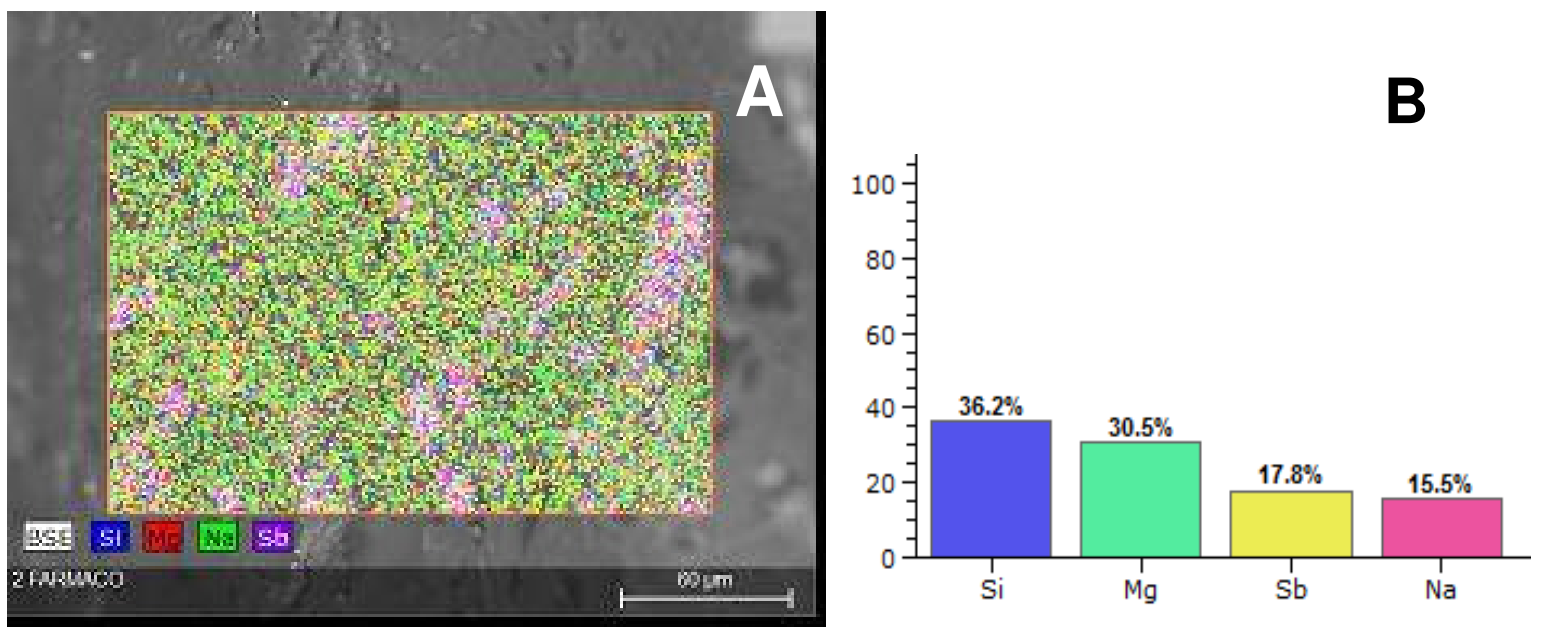

FIGURA 74 - (A) Micrografia de EDS e (B) o gráfico com a porcentagem dos íons $\mathrm{Si}, \mathrm{Mg}, \mathrm{Sb}$ e $\mathrm{Na}$ dispersos na membrana de hidrogel de PVAl/quitosana/1,5\% argila.

Para o sistema PVP/quitosana/argila a FIG. 75 (A e B) apresenta-se a micrografia de EDS e o gráfico com a porcentagem dos íons $\mathrm{Si}, \mathrm{Mg}, \mathrm{Sb}$ e $\mathrm{Na}$ do sistema PVP/quitosana/argila com o fármaco. Neste caso também apresentam-se homogeneamente distribuídos.
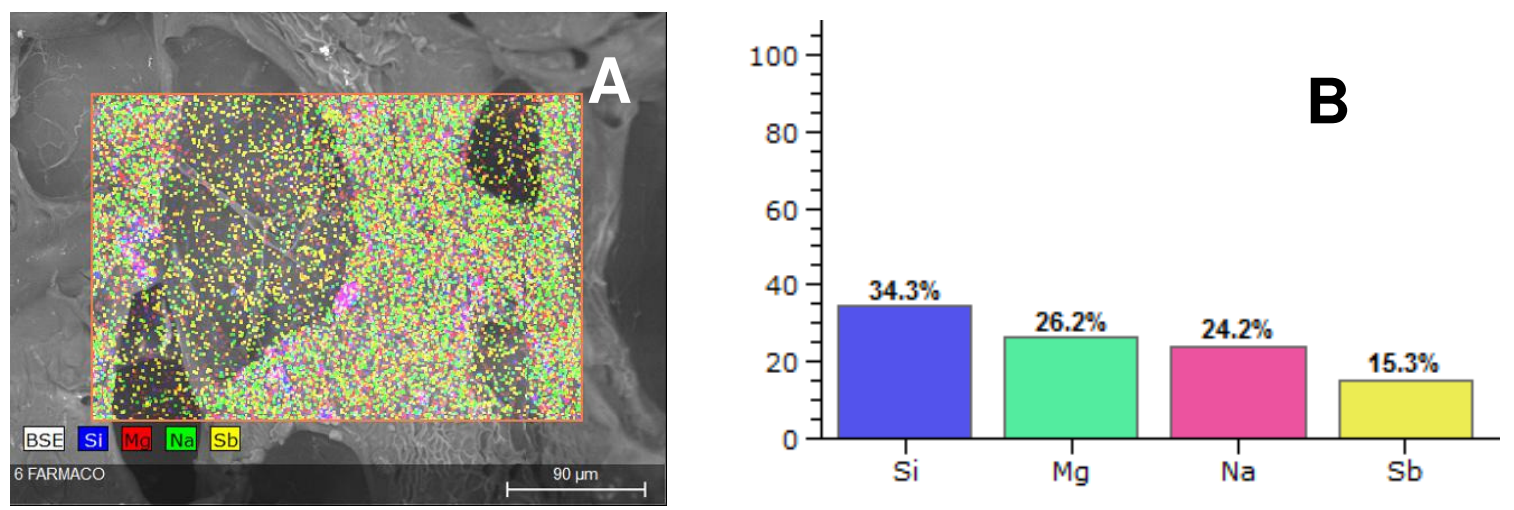

FIGURA 75- (A) Micrografia de EDS e (B) gráfico com a porcentagem dos íons $\mathrm{Si}$, $\mathrm{Mg}, \mathrm{Sb}$ e $\mathrm{Na}$ dispersos na membrana de hidrogel de PVP/quitosana/1,5\% argila.

Nota-se em todas as superfícies de fratura analisadas a presença de aglomerados, inclusive de microdimensão de argila. As amostras com quitosana apresentaram-se com distribuições de íons mais homogêneas, o mesmo ocorrendo com o antimônio praticamente em todos os sistemas, sendo que apenas o sistema de PVAl/argila apresentou concentração de silício muito elevada. 


\subsection{Estudo da nanodispersão da argila nos sistemas por microscopia de força atômica (AFM)}

Este estudo foi feito com o objetivo de analisar a nanodispersão da argila nos sistemas contendo $1,0 \%$ de argila. Observam-se para o sistema PVP/PVAl/argila pontos de argila distribuída na superfície da amostra com pequenas regiões de aglomeração, como mostra a FIG. 76 (A e B). Essa distribuição de nanopartículas na superfície das membranas pôde também ser comparada por EDS, como indicado na FIG. 71.
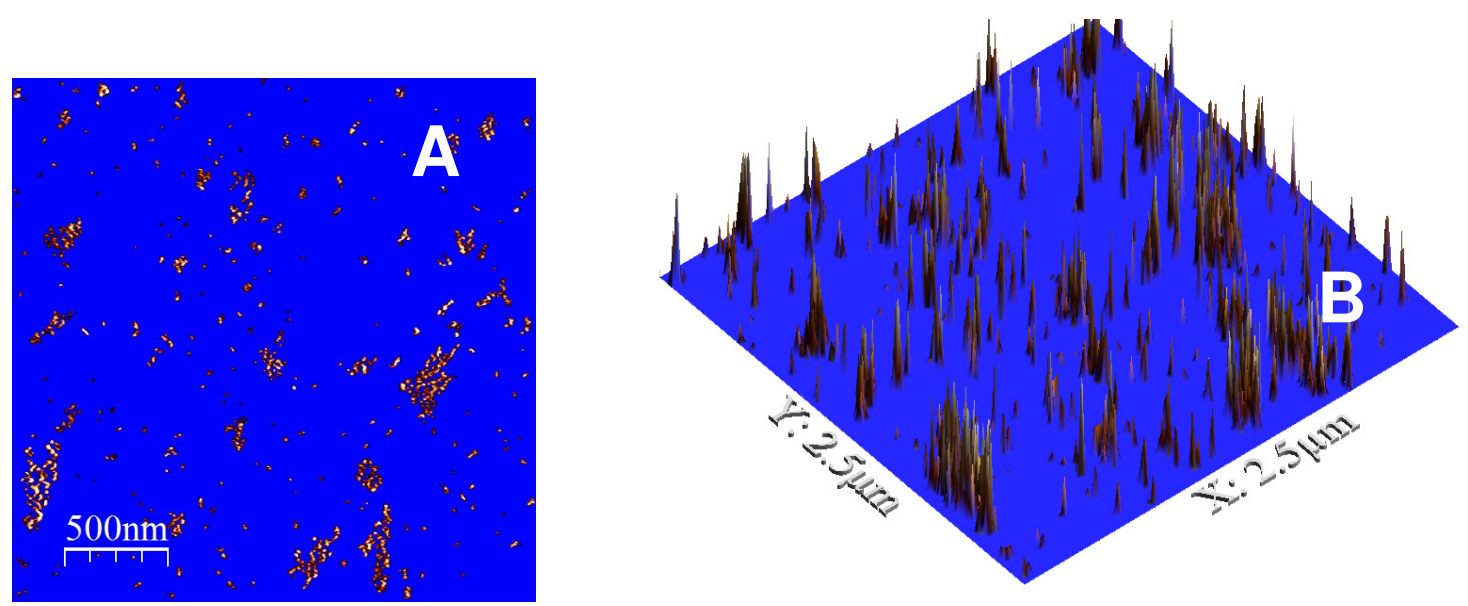

FIGURA 76 - MFA obtida da superfície das membranas de hidrogéis liofilizados PVP/PVAl/1,0\% de argila.

A FIG. 77 (A e B) e a FIG. 78 (A e B) apresentam comportamento diferente nas topografias das superfícies das amostras dos sistemas PVAl/argila e PVP/argila, onde as nanopartículas são diversamente distribuídas.
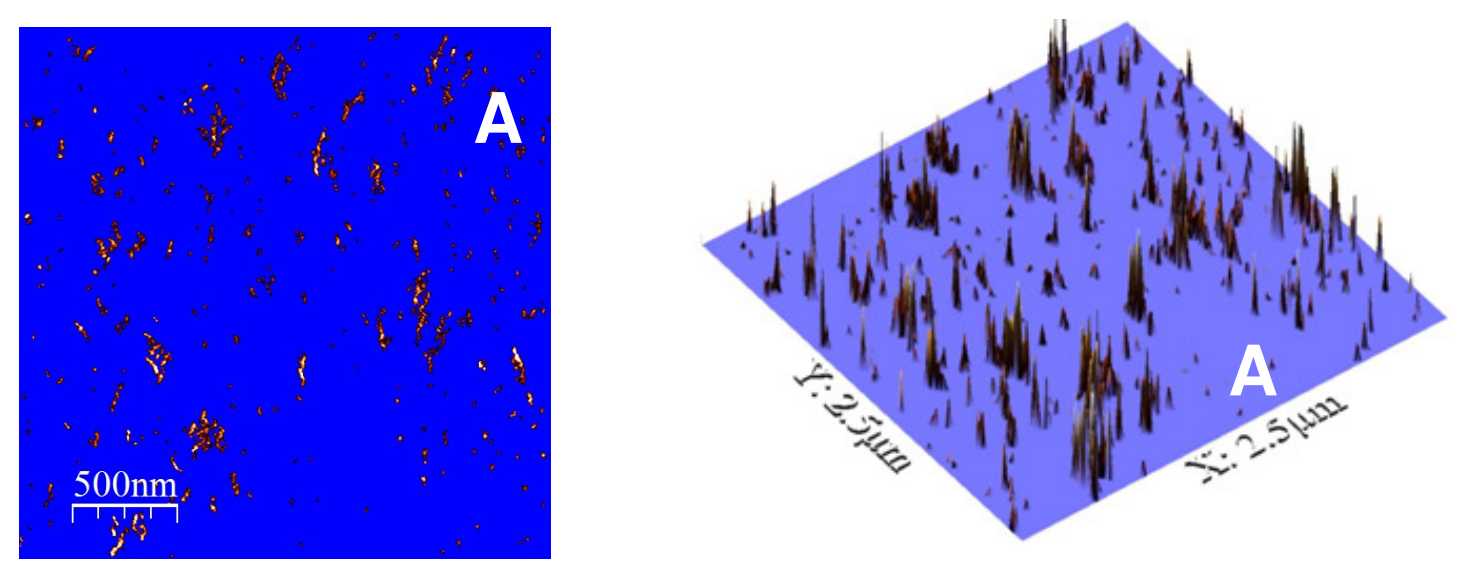

FIGURA 77 - MFA obtida da superfície das membranas de hidrogéis liofilizados de PVAl/1,0\% argila. 

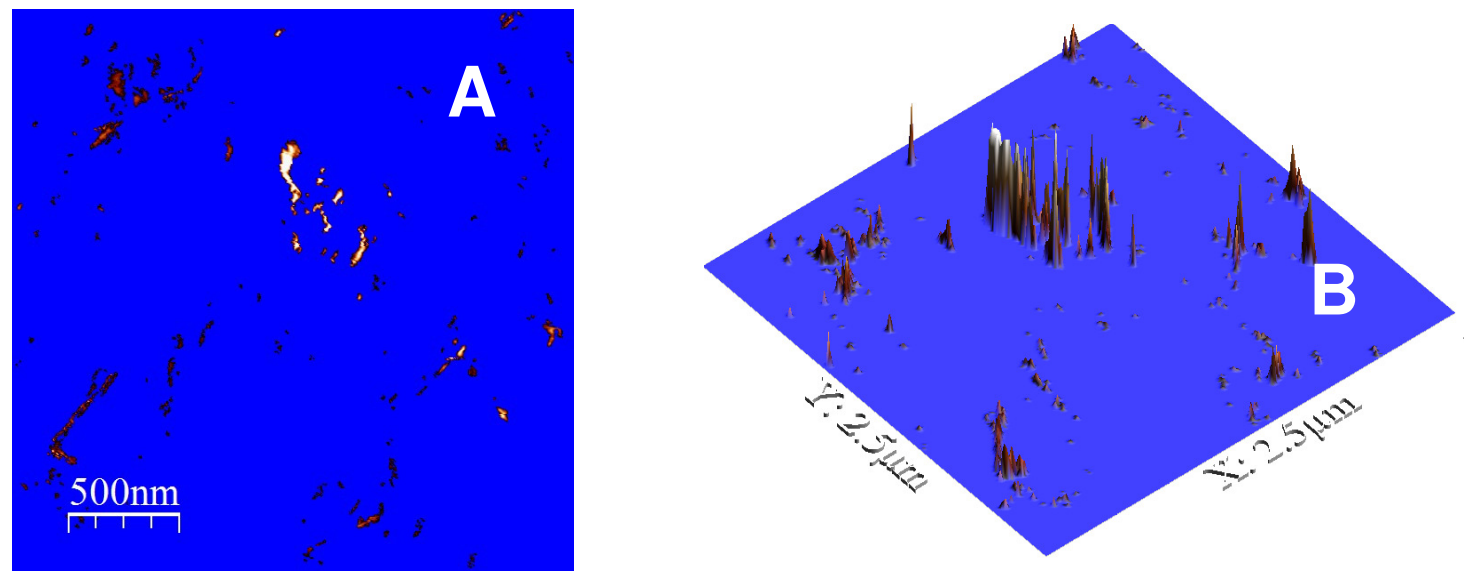

FIGURA 78 - MFA obtida da superfície das membranas de hidrogéis liofilizados de PVP $/ 1,0 \%$ argila.

O PVAl/argila apresenta melhor distribuição das nanopartículas de argila na superfície de fratura, enquanto, o PVP/argila apresenta regiões mais aglomeradas e menor dispersão das nanopartículas da argila na superfície. Esse comportamento foi associado às diferentes formas das interações da argila com os polímeros, uma vez que no nanocompósito PVAl/argila se dá por esfoliação e o nanocompósito PVP/argila se dá por intercalação. Supõe-se que essas interações polímero argila dificultam a formação de aglomerados.

Observa-se no sistema PVAl/quitosana/argila que a presença da quitosana pouco influi na dispersão das nanopartículas da argila na superfície da amostra comparando-se ao sistema PVAl/argila da FIG. 77. Nota-se que na maior parte da superfície da amostra encontram-se nanopartículas de argilas dispersas com poucas aglomerações assim indicado na FIG. 79 (A e B).
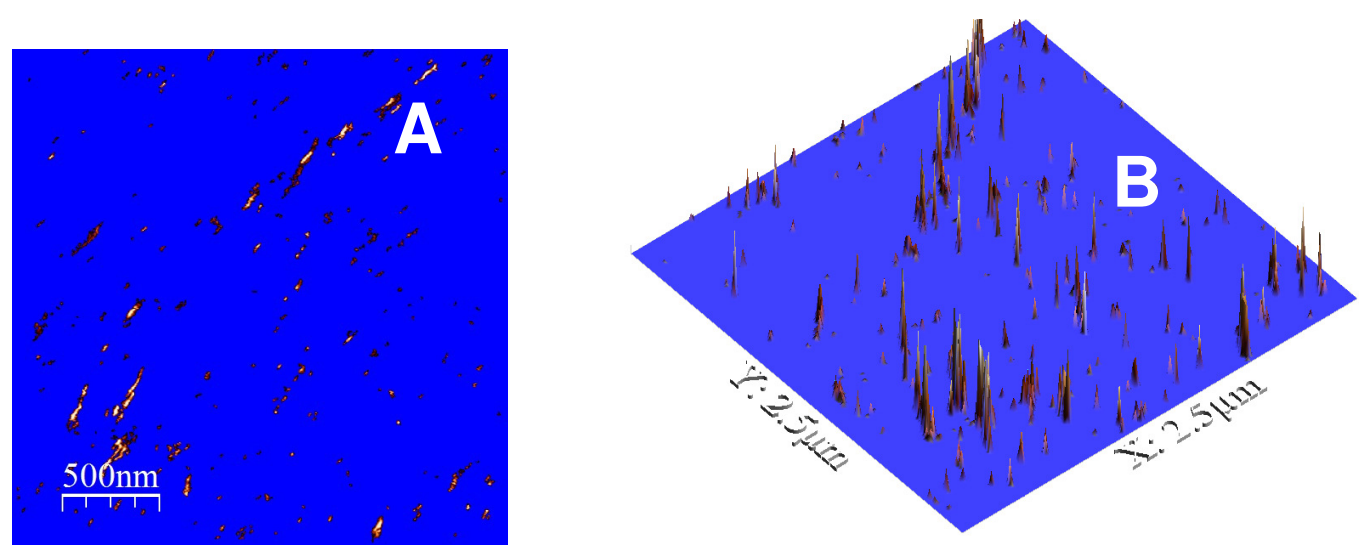

FIGURA 79 - MFA obtida da superfície da amostra das membranas de hidrogéis liofilizados de PVAl/quitosana/ $1,0 \%$ de argila. 
Para o sistema PVP/quitosana/argila observa-se que a presença da quitosana contribuiu para melhor dispersão das nanopartículas na superfície de fratura da amostra, como mostra a FIG. 80 (A e B). Essa organização das nanopartículas pode ser confrontada com a superfície da amostra do sistema PVP/argila como segue nas FIG. 78 A e 78 B.
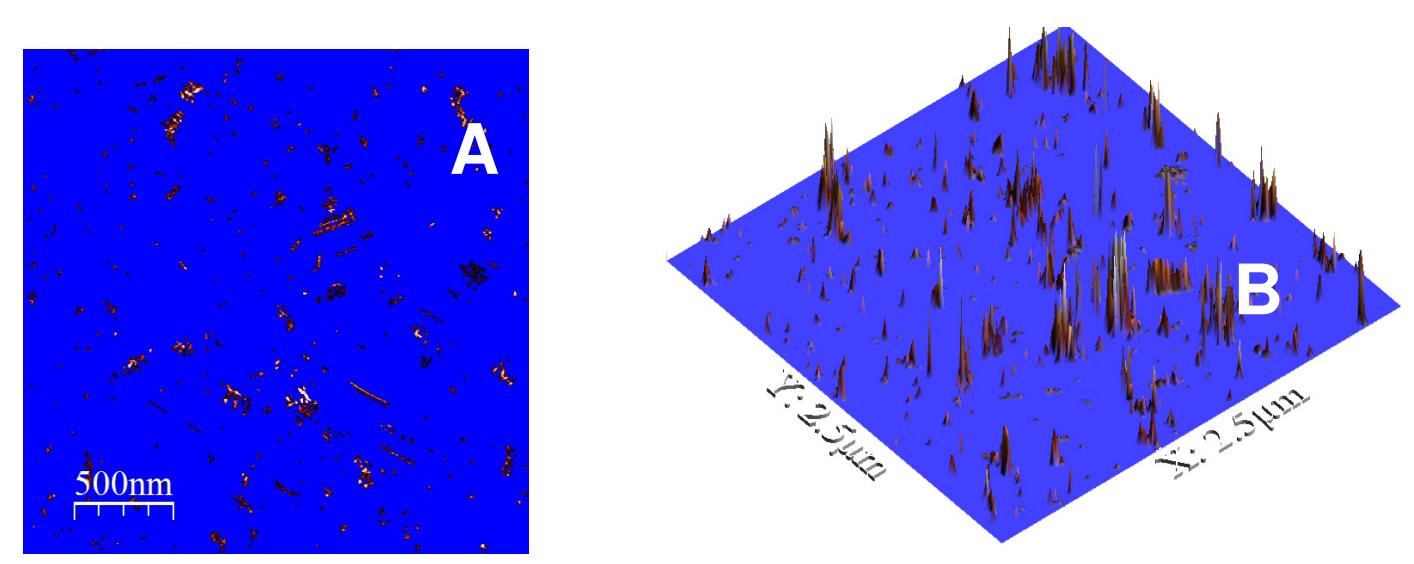

FIGURA 80 - MFA obtidas da superfície da amostra das membranas de hidrogéis liofilizados de PVP/quitosana 1,0\% argila.

As amostras de hidrogéis utilizadas para as análises de microscopia de força atômica foram liofilizadas, e durante o procedimento das análises, observou-se a rugosidade de superfície nelas. Sendo amostras higroscópicas, não foi possível estabilizar-Ihes a umidade das mesmas durante as análises, devido às condições do laboratório não climatizado temporariamente, além da falta de nitrogênio para estabilização das amostras.

Para obtenção de resultados com mapeamento de nanopartículas da argila na escala nanométrica por esse método de imagens, seria viável preparar as amostras em forma de filmes, o que não foi possível no presente trabalho.

\subsection{Citotoxicidade das membranas de hidrogéis}

A biocompatibilidade dos hidrogéis foi verificada in vitro por meio do teste de citotoxicidade. A medida da citotoxicidade foi realizada pelo cálculo do índice de citotoxicidade IC50\% que determina o potencial citotóxico do material 
testado e indica a concentração do extrato que reduz em $50 \%$ a viabilidade celular no ensaio. O IC50\% foi obtido colocando-se em gráfico, conforme FIG. 81 a 85, a porcentagem de viabilidade celular em relação à concentração do extrato. Neste trabalho a avaliação da citotoxicidade foi realizada utilizando ensaio de captação de vermelho neutro. Controles positivos e negativos foram necessários para confirmar o desempenho adequado do procedimento do teste, para avaliar os resultados de toxicidade usando a sensibilidade das células.

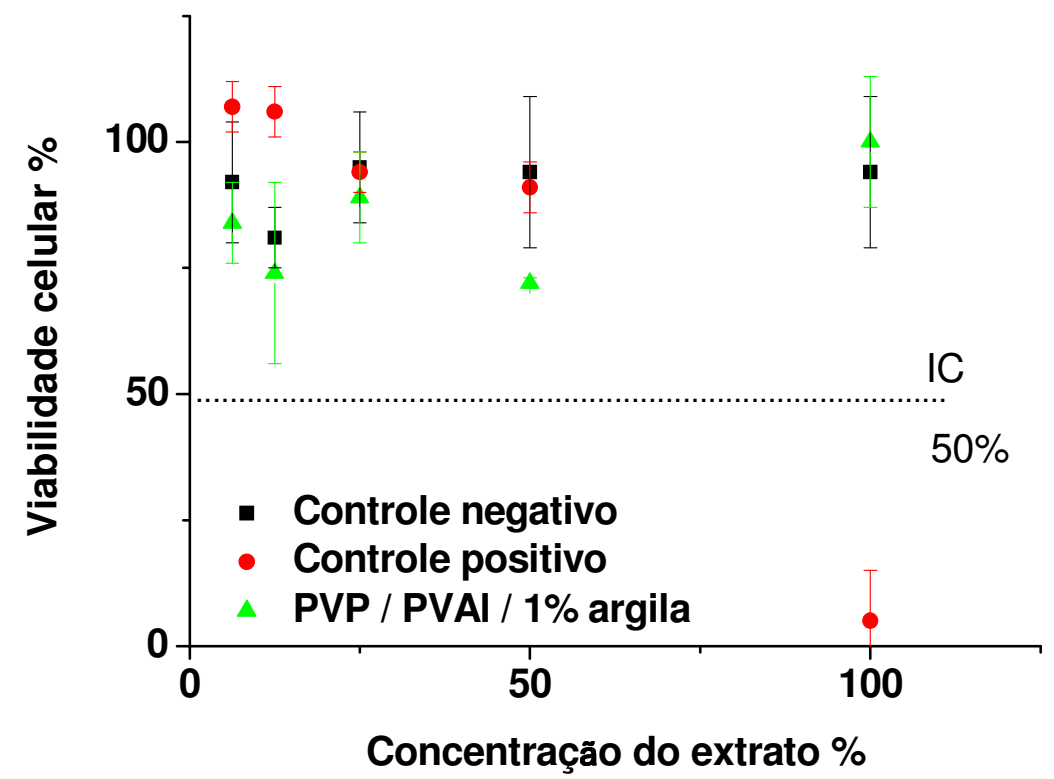

FIGURA 81 - Curva de viabilidade celular no ensaio de citotoxicidade pelo método de incorporação do vermelho neutro, da membrana de hidrogel obtida por PVP/PVAl/argila, reticulada por radiação gama, dose de 25 kGy. 


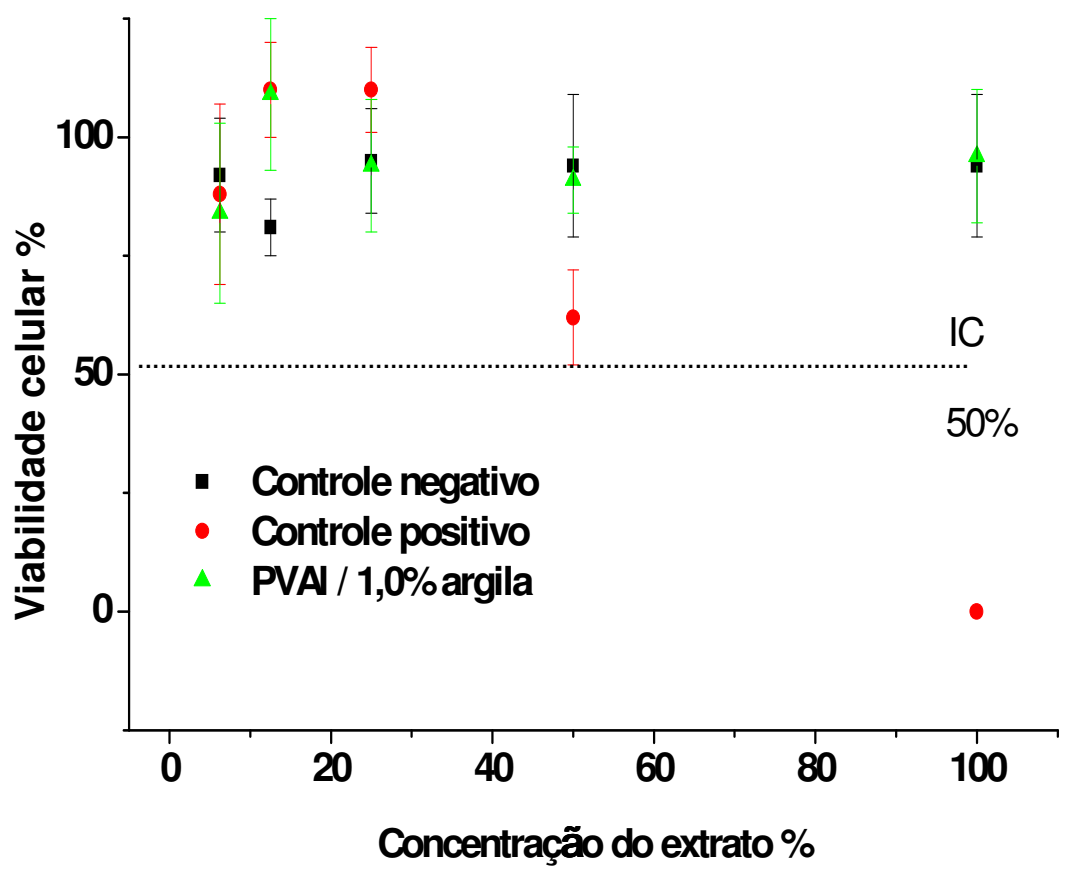

FIGURA 82 - Curva de viabilidade celular no ensaio de citotoxicidade pelo método de incorporação do vermelho neutro, da membrana de hidrogel obtida por PVAl/argila, reticulado por radiação gama, dose de $25 \mathrm{kGy}$.

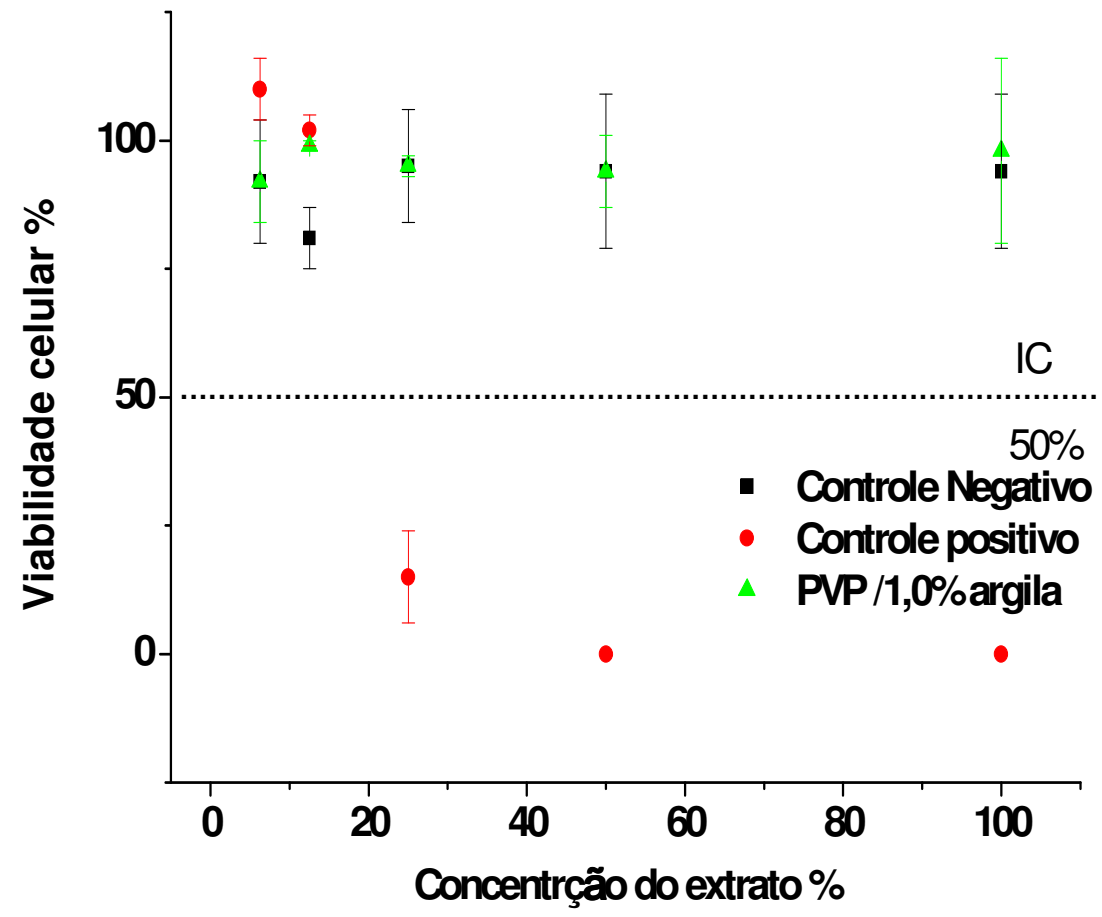

FIGURA 83 - Curva de viabilidade celular no ensaio de citotoxicidade pelo método de incorporação do vermelho neutro, da membrana de hidrogel obtida por PVP/ argila, reticulado por radiação gama, dose de 25 kGy. 


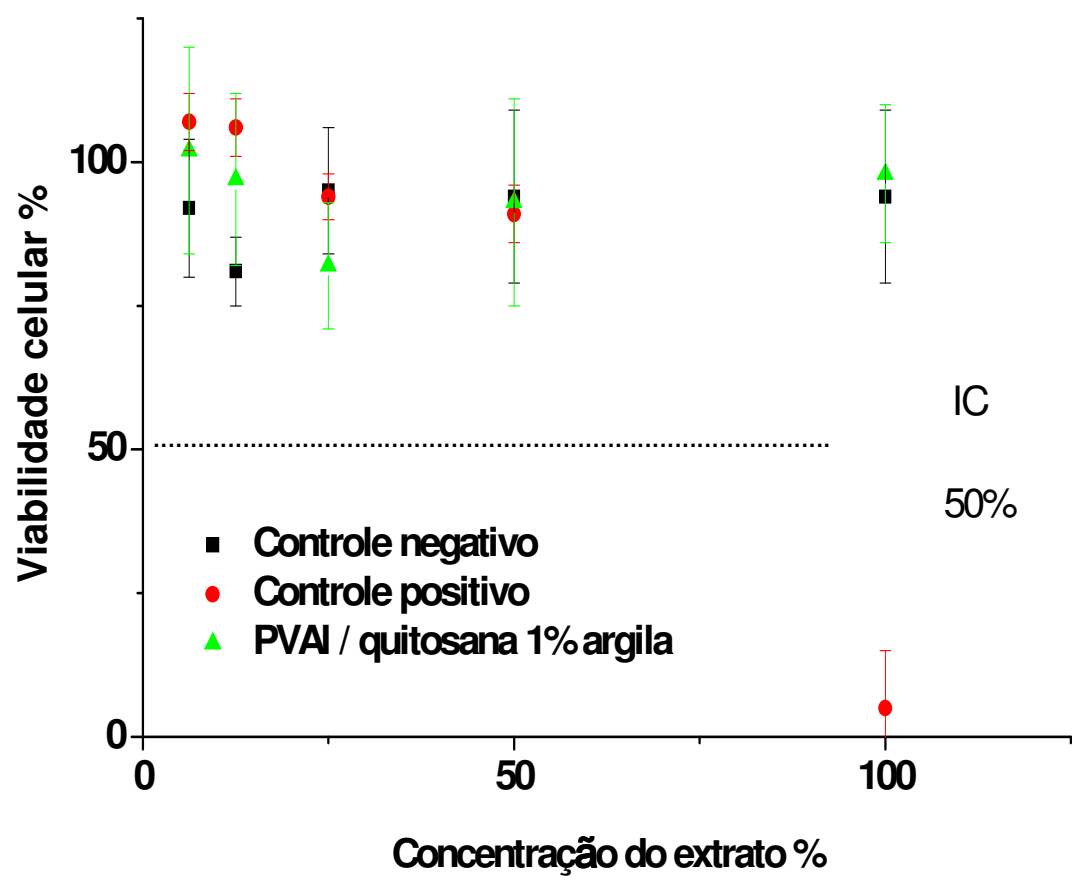

FIGURA 84 - Curva de viabilidade celular no ensaio de citotoxicidade pelo método de incorporação do vermelho neutro, da membrana de hidrogel obtida por PVAl/quitosana/argila, reticulado por radiação gama, dose de 25 kGy.

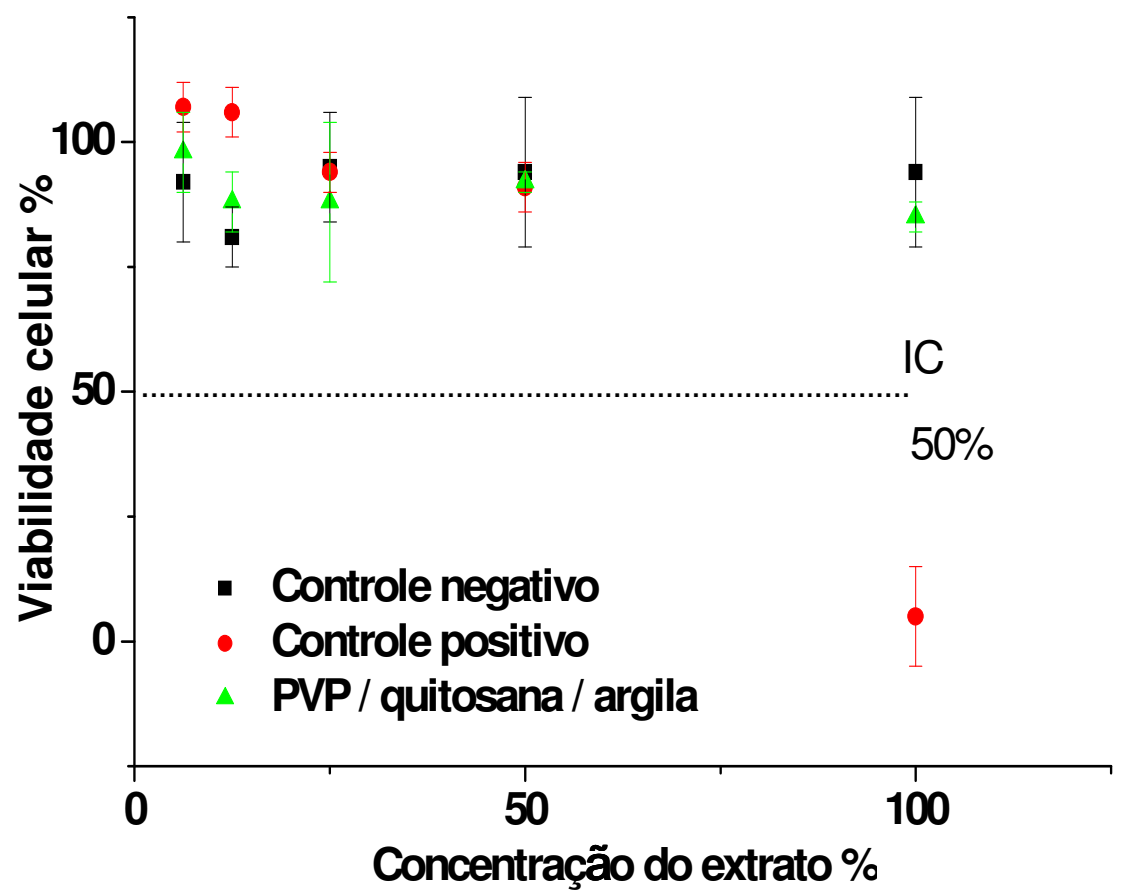

FIGURA 85 - Curva de viabilidade celular no ensaio de citotoxicidade pelo método de incorporação do vermelho neutro, da membrana de hidrogel obtida por PVP/quitosana/argila, reticulado por radiação gama, dose de 25 kGy. 
Nos testes de citotoxicidade foi observado comportamento idêntico das amostras testadas com o controle negativo. Então, é possível afirmar que os hidrogéis sintetizados por reticulação gama obtidos pelos cinco sistemas desenvolvidos neste trabalho não causam morte ou prejuízo a célula de mamífero sendo, portanto, caracterizados como não citotóxicos. O comportamento apresentado pelos hidrogéis e controles foi semelhante ao encontrado em trabalhos publicados anteriormente que também avaliaram "in vitro" a citotoxicidade de hidrogéis de PVP (Lugão, 1999; Lopérgolo, 2003).

Os resultados obtidos nesta fase inicial orientaram a continuidade dos testes e utilização de modelos experimentais para verificação de outros critérios como irritabilidade e alergenicidade, que também comprovam a biocompatibilidade. Desta forma, apenas apresentar citotoxicidade não implica necessariamente na biocompatibilidade do material.

\subsection{A extração do glucantime das membranas de hidrogéis analisada por espectrofotometria UV-visível $510 \mathrm{~nm}$.}

Encontra-se na literatura atual grande evidência de estudos de liberação de fármacos a partir de matrizes poliméricas. Os hidrogéis poliméricos de PVAI/PVP podem ser sintetizados por radiação gama, reticulação de origem química e processo por ciclos térmico. Esses processos de reticulação foram usados durante o trabalho de Mestrado (Oliveira 2008), para os três processos de reticulação observou-se no período de 24 horas a liberação do fármaco distinta, sendo mais lenta a partir das membranas reticuladas por radiação gama.

Deste modo, o processo de reticulação escolhido foi o de radiação gama e para demonstrar que esse processo de reticulação não alterou a composição do fármaco, uma amostra do glucantime irradiado foi analisada quantitativamente e comparada com a concentração do glucantime sem ser irradiado. Essa análise foi realizada pelo espectrofotômetro no UV - visível, $\lambda=$ $510 \mathrm{~nm}$ para verificar se a radiação alterou a parte ativa do fármaco que é o antimoniato. Observa-se que não ocorreu alteração no resultado da solução 
analisada, apresentando a concentração igual a da solução padrão não irradiada, apresentados na TAB. 16.

TABELA 16 - Concentrações do fármaco glucantime solução padrão e solução irradiada em dose de 25 kGy.

Amostra Solução padrão $\mu \mathrm{g} / \mathrm{L}^{-1} \quad$ Solução irradiada $\mu \mathrm{g} / \mathrm{L}^{-1}$

Para o estudo de liberação do fármaco foram selecionadas membranas de hidrogéis com 1,5\% de argila e glucantime. Segundo Ikeda e colaboradores (1994), a área disponível para a difusão do soluto é o espaço livre que existe entre as cadeias macromoleculares de hidrogéis e quanto mais reticulado for 0 hidrogel, menores serão os espaços entre elas. Quando os espaços entre as cadeias forem preenchidos por água ou fluidos biológicos, alcançando equilíbrio de intumescimento, essas cadeias se alongarão e as partículas menores se difundirão para fora da membrana de hidrogel.

\subsection{Extração do glucantime das membranas de hidrogéis analisada por espectrometria de absorção atômica com atomização por forno de grafita (GF-AAS).}

A avaliação da liberação foi feita a partir de uma mesma amostra da membrana, analisada integralmente. As amostras dos hidrogéis com a concentração do fármaco foram colocadas em frascos com $40 \mathrm{~mL}$ de água e em seguida em uma centrifugadora à temperatura de $37,0^{\circ} \mathrm{C}$ sob agitação a $100 \mathrm{rpm}$ (modo dinâmico) durante $48 \mathrm{~h}$ e nos períodos de 3, 6, 9, 12, 24, 36 e 48 h. Após essas etapas, foi retirada uma alíquota de $2 \mathrm{~mL}$ para análise da concentração de antimônio, que foram substituídos por $2 \mathrm{~mL}$ de água a cada alíquota retirada.

Supõe-se que este tempo tenha sido suficiente para que o estado estacionário da liberação do glucantime fosse estabelecido. Isto foi baseado no fato de que com mecanismo de difusão deste sistema, controlado por 
intumescimento da matriz polimérica reticulada, a difusão deve aumentar à medida que a água penetra no polímero. A FIG. 86 (A, B, C, D, E e F) representa as curvas de liberação
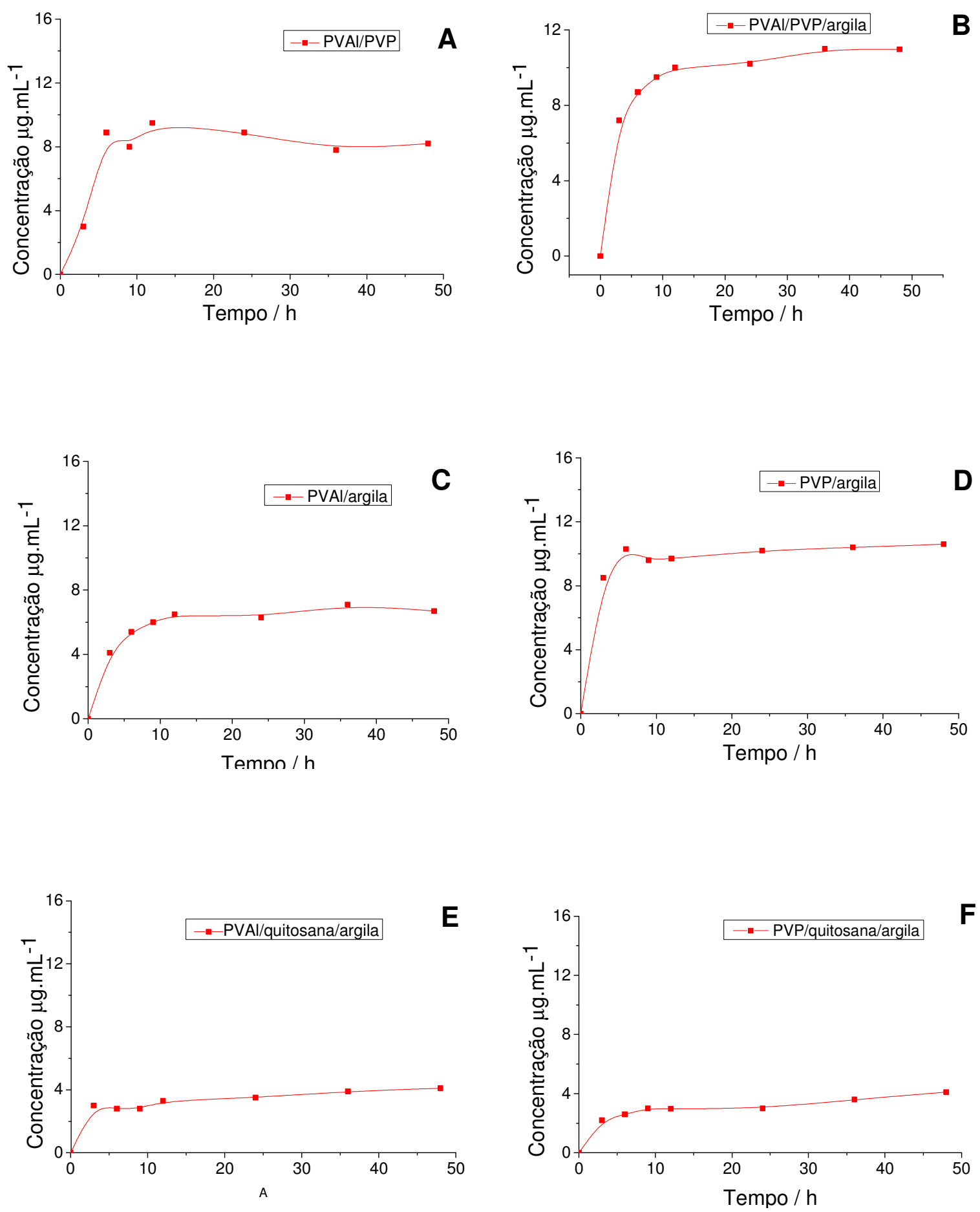

FIGURA 86 - Curvas de liberação do fármaco glucantime das membranas de hidrogel (A) PVP/PVAl (B) PVP/PVAl/argila (C) PVAl/argila (D) PVP/argila (E) PVAl/quitosana/argila (F) PVP/quitosana/argila. 
Foi verificado no procedimento dinâmico de liberação que para 0 sistema PVP/ PVAl/argila há a maior concentração liberada do antimônio comparando-se com o PVP/PVAl. No caso dos sistemas de um único polímero identificou-se para o sistema PVP/argila uma liberação mais rápida e com maior concentração liberada, comparando-se ao sistema PVAl/argila. No entanto a liberação do sistema PVP/PVAl/argila ocorre também no modo estático (sem agitação).

Para os sistemas com quitosana/argila há uma maior retenção do antimônio comparando-se com os outros sistemas analisados.

Seguindo o mesmo procedimento, porém sem agitação durante a extração, obteve-se uma liberação estática em que foram analisadas alíquotas retiradas no período de $48 \mathrm{~h}$. Cada amostra na extração continha no início aproximadamente $4,6 \mathrm{mg}$ de antimônio. Obtiveram-se durante o período de $48 \mathrm{~h}$ perfis de liberação diferentes para cada sistema. A FIG. 87 (A, B, C, D, E e F) representa o modo estático da liberação respectivamente para os sistemas PVP/PVAl, PVP/PVAl/1,5\% argila, PVAl/1,5\% argila, PVP/1,5\% argila, PVAl/quitosana/1,5\% argila e PVP/quitosana/1,5\% argila.

Como resultado a membrana de hidrogel PVP/PVAl/argila apresentou concentração liberada após 10 h com maior concentração de antimônio liberado, comparando-se com a membrana PVP/PVAI sem argila.

Foi perceptível a liberação do fármaco em todos os sistemas analisados nesse trabalho, sendo que o equilíbrio de liberação ocorreu a partir das 6 h com algumas variações de acordo com a formulação das membranas.

Nota-se pela curva de liberação PVP/argila que a estabilidade da liberação ocorre a partir de 6 h e que houve liberação mais rápida, comparandose com a membrana PVAl/argila onde ocorre equilíbrio de liberação a partir de $10 \mathrm{~h}$, mantendo-se a liberação lenta e estável durante o período analisado. 

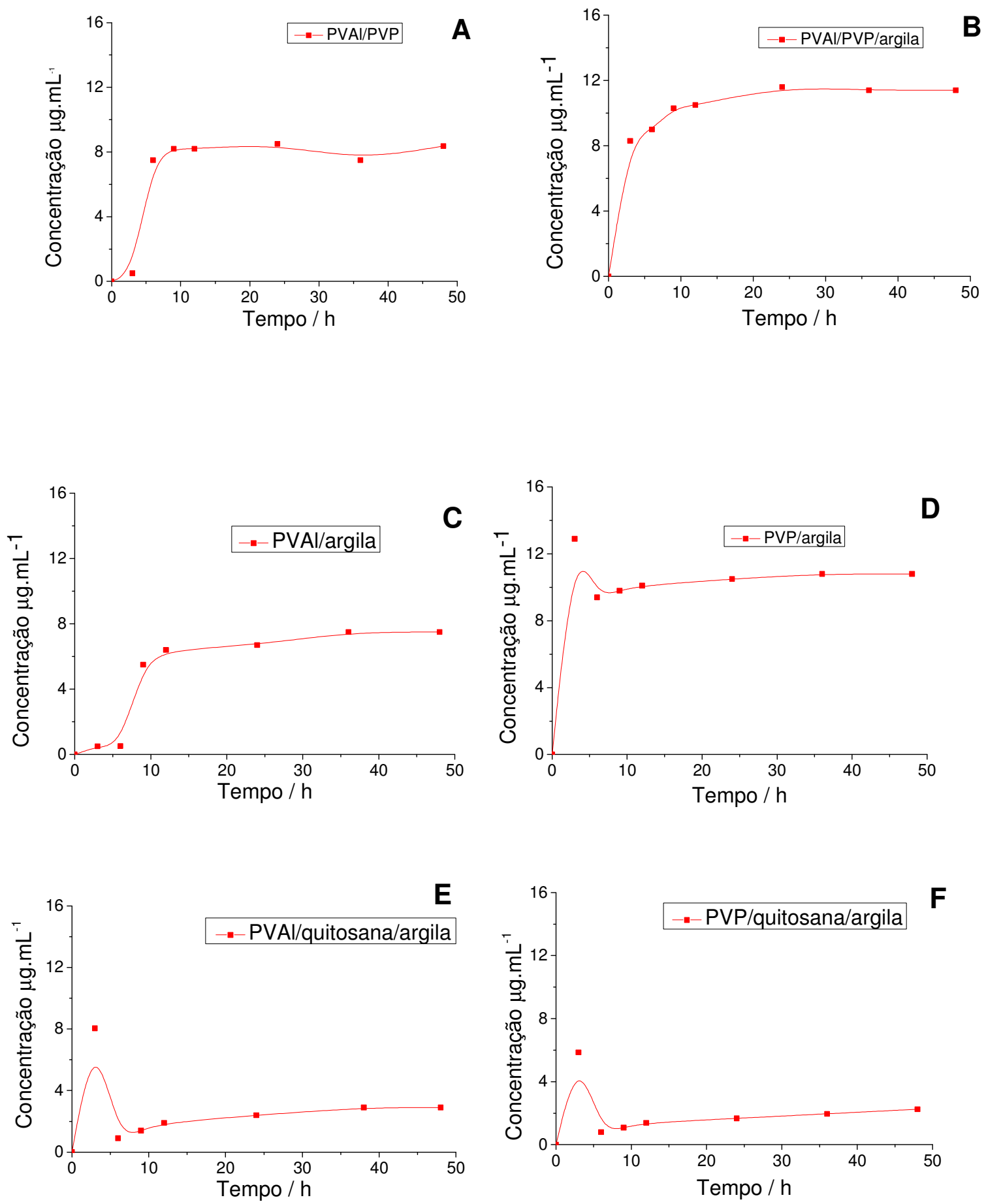

FIGURA 87 - Curvas da cinética da liberação do glucantime das matrizes de hidrogéis (A) PVP/PVAl, (B) PVP/PVAl/1,5\%argila, (C) PVAl/1,5\%, (D) PVP/1,5\% argila, (E) PVAl/quitosana/1,5\% argila e (F) PVP/quitosana/1,5\% argila.

Para o sistema representado por PVAl/quitosana/argila, o equilíbrio de liberação ocorre a partir de $9 \mathrm{~h}$, com uma liberação relativamente mais lenta, comparando-se com o PVP/quitosana/argila, ambas mantendo alguma liberação constante durante o período analisado por $48 \mathrm{~h}$. 
Ficou evidente que a liberação mais lenta do fármaco para os sistemas PVAl/quitosana/argila e PVP/quitosana/argila estabelece correlação com o tipo de retículo formados pela quitosana. No ensaio estático observa-se que maior concentração liberada do fármaco ocorre no início, entre $6 \mathrm{~h}$ as $9 \mathrm{~h}$ devido ao fármaco das camadas superficiais da amostra, mantendo-se o restante do fármaco retido na malha interna da amostra.

Propõe-se que a liberação do glucantime dos hidrogéis ocorreu por difusão, a partir de um gradiente de concentração da mesma amostra com e sem agitação em todos os sistemas estudados.

É perceptível que tanto na extração do modo dinâmico quanto na liberação pelo modo estático, a concentração do antimônio apresenta comportamento de liberação semelhante. Apenas no sistema com quitosana /argila ocorreu menor liberação fato que foi relacionado aos retículos formados durante a reticulação pela quitosana.

Postula-se que o intumescimento no modo dinâmico favoreceu para esses sistemas com quitosana o aumento da liberação, comparando-se com o sistema estático onde ocorre menor liberação do antimônio, indicadas nas FIG. 87 E e FIG 87 B.

As concentrações do antimônio liberado pelos seis sistemas encontram-se ilustrados nas TAB. 18 a 23 no apêndice. Supõe-se que o processo de adsorção e dessorção da molécula do glucantime em argilas catiônicas sejam em parte responsáveis pela liberação controlada. Esse resultado foi atribuído à protonação do glucantime no espaço interlamelar da argila trocada com íons $\mathrm{Na}^{+}$, permitindo retenção da molécula no espaço interlamelar por um mecanismo de troca catiônica.

As argilas com cátions trocáveis da classe das hectoritas podem fazer o papel de carreadoras dessas espécies e, a depender da interação da molécula do fármaco com a argila, o tempo de liberação pode ser ajustado. Segundo Lagaly (2001), esse ajuste ocorreu para liberação controlada com pesticidas, 
usando a argila como carregador. Segundo os autores Lagaly (2001) e TeixeiraNeto (2009), o tipo de argila quimicamente modificada deve ser escolhido de acordo com a aplicação do material.

Considerando as curvas de liberação das membranas de hidrogéis, a obtenção de membranas contendo fármaco para liberação controlada direta em lesão cutânea utilizando-se argilas como carreadoras de ativos mostra-se bastante viável. 

AMASTIGOTAS (L. amazonenses) RESPONSÁVEIS PELA LEISHMANIOSE TEGUMENTAR AMERICANA (LTA).

O teste "in vivo" foi feito a partir do monitoramento de um modelo experimental em que foram aplicadas as membranas de hidrogéis em três grupos distintos. Foram utilizadas membranas de PVP/PVAl e PVP/PVAl/argila 1,5\%.

\subsection{Grupo $1^{\circ}$ - Camundongos Balb/C tratado}

Entre estudos preliminares (pilotos) e a autorização da comissão de ética para o ínicio dos primeiros resultados somaram-se 24 meses. $O$ primeiro grupo com 4 camundongos foi inoculado no dorso. Foram acompanhados durante 3 meses, não apresentaram lesões e nem outra manifestação que pudesse confirmar que a inoculação havia sido eficiente.

O segundo piloto foi inoculado seguindo o mesmo procedimento e também foi acompanhado por 3 meses e não foram observadas alterações durante esse período. Após essas duas tentativas concluiu-se que no dorso, por ter pouca vascularização o procedimento tornava-se ineficiente.

Para o terceiro piloto foram inoculados 10 camundongos na pata traseira usando a mesma quantidade de amastigotas e o mesmo procedimento anterior. Após 20 dias, surgiram lesões nas patas inoculadas. Um desses camundongos quando completou 70 dias foi usado para retirar os amastigotas para as próximas inoculações em outra população de camundongos.

Quatro camundongos Balb/C tratados com membranas de PVAI/PVP com glucantime $(A-1)$ e 4 tratados com membranas de PVAI/PVP sem 0 glucantime (A-2). No período de duas semanas após o início do tratamento os ferimentos dos grupos (A-1 e A-2) tratados apresentaram uma crosta grossa sem regressão aparente. Na terceira semana foi observada uma regressão no tamanho das lesões dos animais tratados com a membrana contendo o fármaco, 
sendo que os que foram tratados com a membrana sem o fármaco permaneceram estáveis, sem mudanças significativas, conforme as FIG. 88 (A e $B) ; 89$ ( $A$ e $B)$ e 90 (A e B).

Foi possível identificar que depois de quatro semanas usando o curativo houve redução de $50 \%$ do tamanho do ferimento. O tratamento foi seguido por mais quatro semanas, não apresentando mais regressão e os ferimentos permaneceram com uma crosta escura.
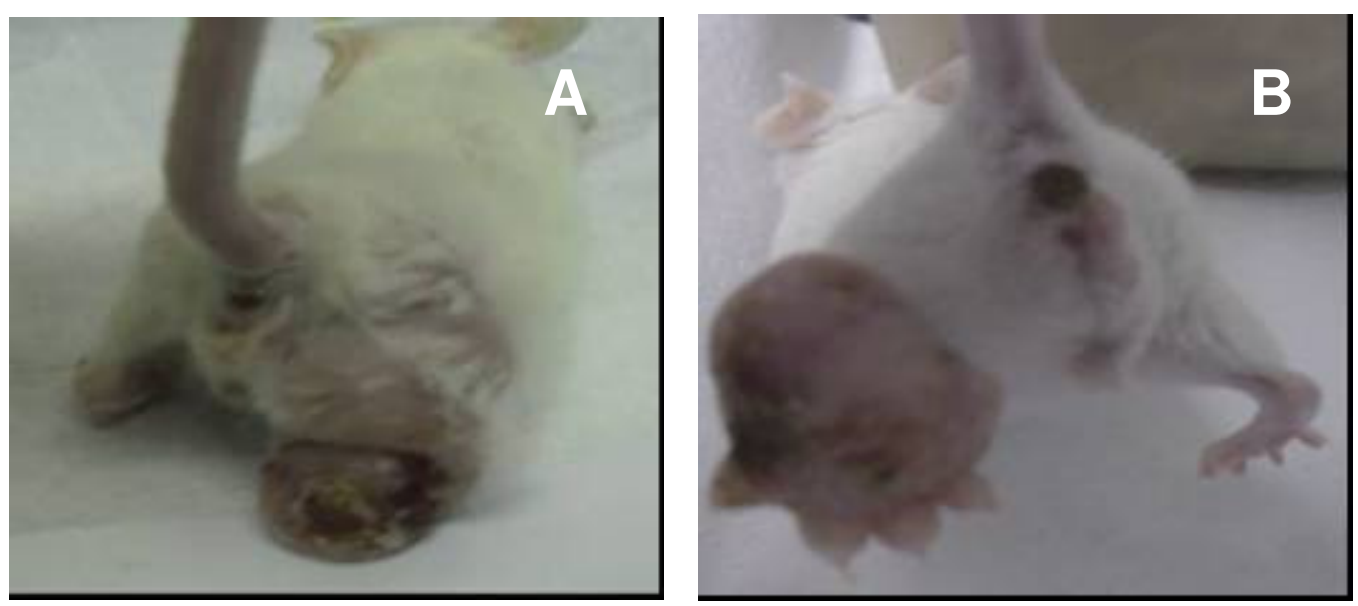

FIGURA 88 - Grupo 1 lesão cutânea na pata dos modelos experimentais (A e B) controles sem tratamento.
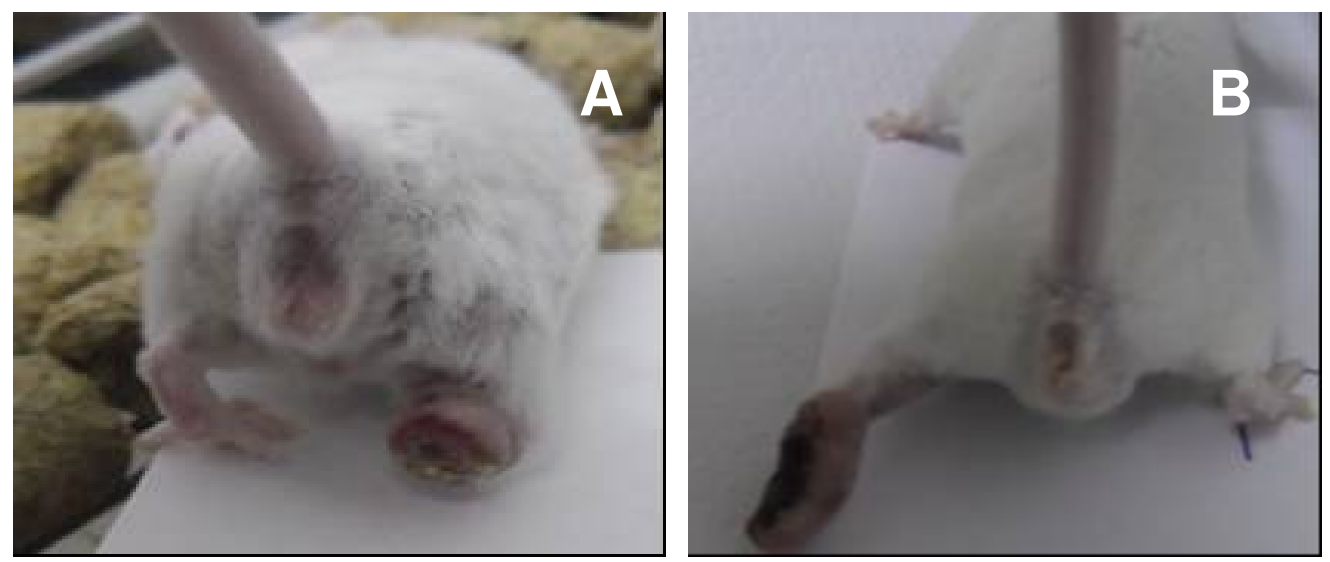

FIGURA 89 - Grupo 1 redução da lesão cutânea na pata dos modelos experimentais (A e B) tratados com membrana de PVAl/PVP/ glucantime. 

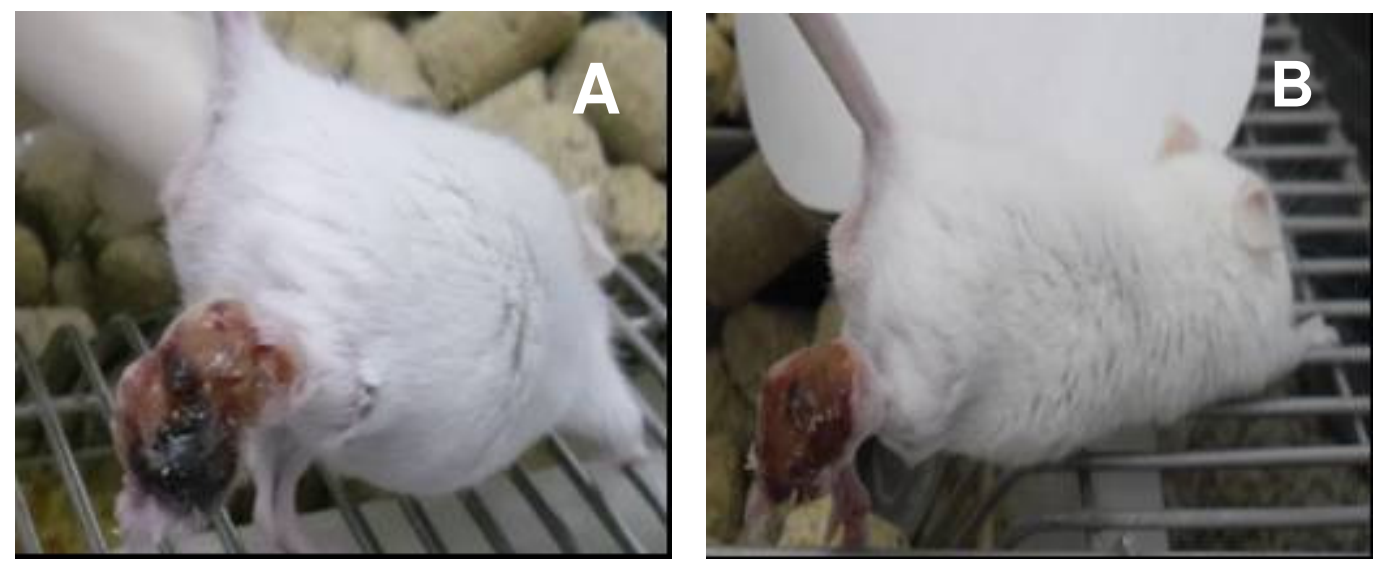

FIGURA 90 - Grupo 1 lesão cutânea na pata dos modelos experimentais (A e B) tratados com membrana de PVAI/PVP sem glucantime.

\subsection{Grupo 2 - Camundongos Balb/C tratados}

Como os resultados anteriores mostraram uma redução da lesão de forma significativa, foi dada continuidade à investigação, para o $2^{\circ}$ grupo foi adicionada argila na formulação dos hidrogéis. Quatro animais pertencentes ao $2^{\circ}$ grupo infectados com L. amazonensis com lesões definidas, foram tratados com membranas de PVAl/PVP/1,5\% argila/glucantime. Dois animais controle ficaram sem tratamento. A FIG. 91 (A e B) e 92 (A e B) apresentam as lesões dos animais com e sem tratamento.

Com esse tratamento, observou-se uma redução de $70 \%$ das lesões no período de quatro semanas no grupo 2. O tratamento foi mantido por mais quatro semanas sem evolução aparente.
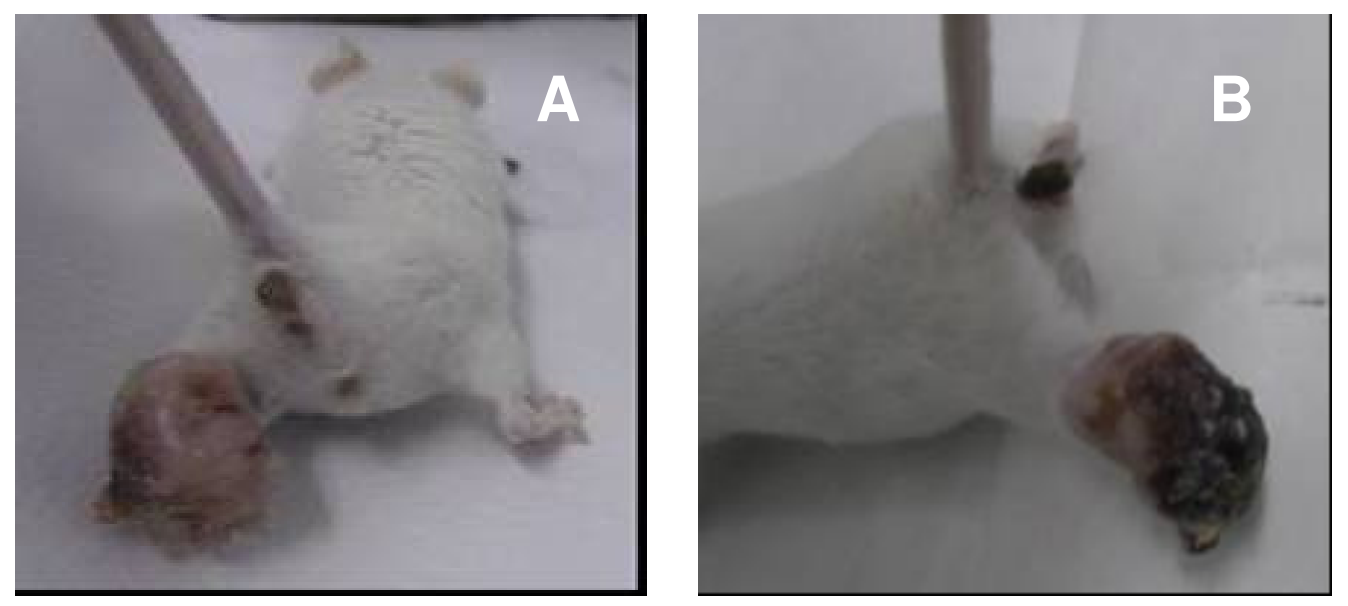

FIGURA 91 - Grupo 2 lesão cutânea na pata dos camundongos controles (A e B), sem tratamento. 

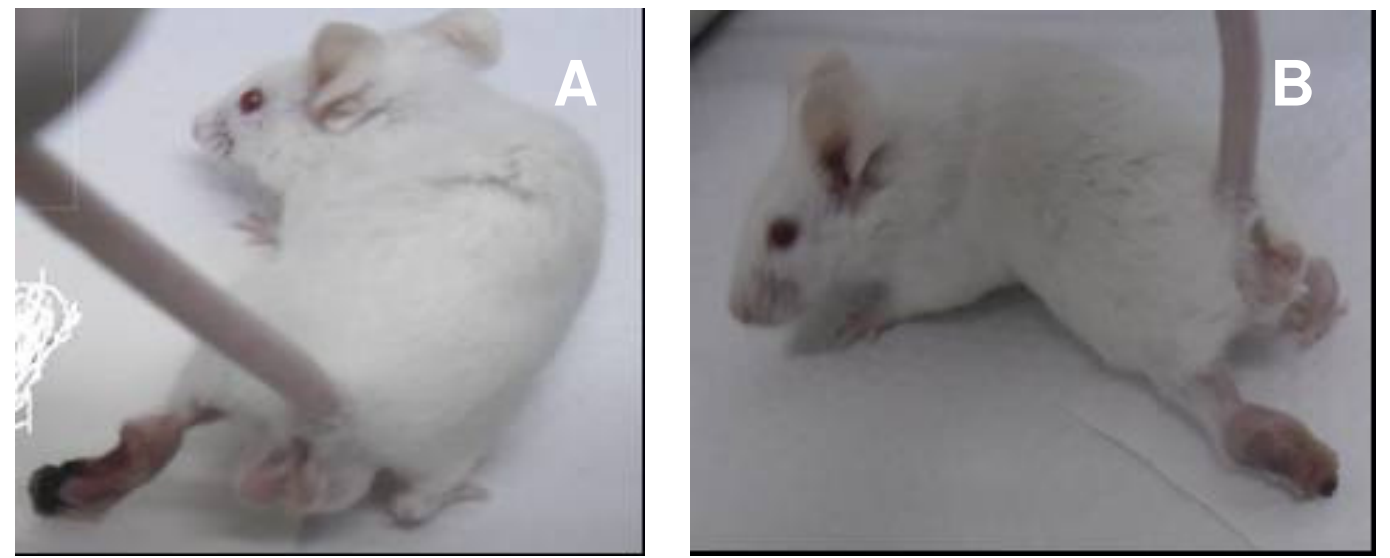

FIGURA 92 - Grupo 2 redução da lesão cutânea na pata dos camundongos Balb/C (A e B) tratados com PVAl/PVP/1,5\%argila/glucantime.

\subsection{Grupo 3 - Camundongos Balb/C tratados}

Durante 0 tratamento dos grupos experimentais anteriores a concentração do glucantime foi equivalente ao tratamento de uso via endovenoso, no qual toda concentração é injetada diretamente na corrente sanguínea. No entanto, por ser aplicado em uso tópico e a liberação de forma gradativa, percebeu-se que seria necessário aumentar a concentração do fármaco para obter-se um resultado eficiente da regressão até a cicatrização da lesão.

Quatro animais foram tratados com PVAl/PVP/glucantime e 4 tratados com PVAI/PVP/1,5\% argila/Glucantime, apresentados na FIG. 93 (A e B). Observou-se que os animais do grupo 3 tratados com a membrana PVAl/PVP /Glucantime apresentaram resultados semelhantes ao $2^{\circ}$ grupo sem mudanças significativas adicionais. 

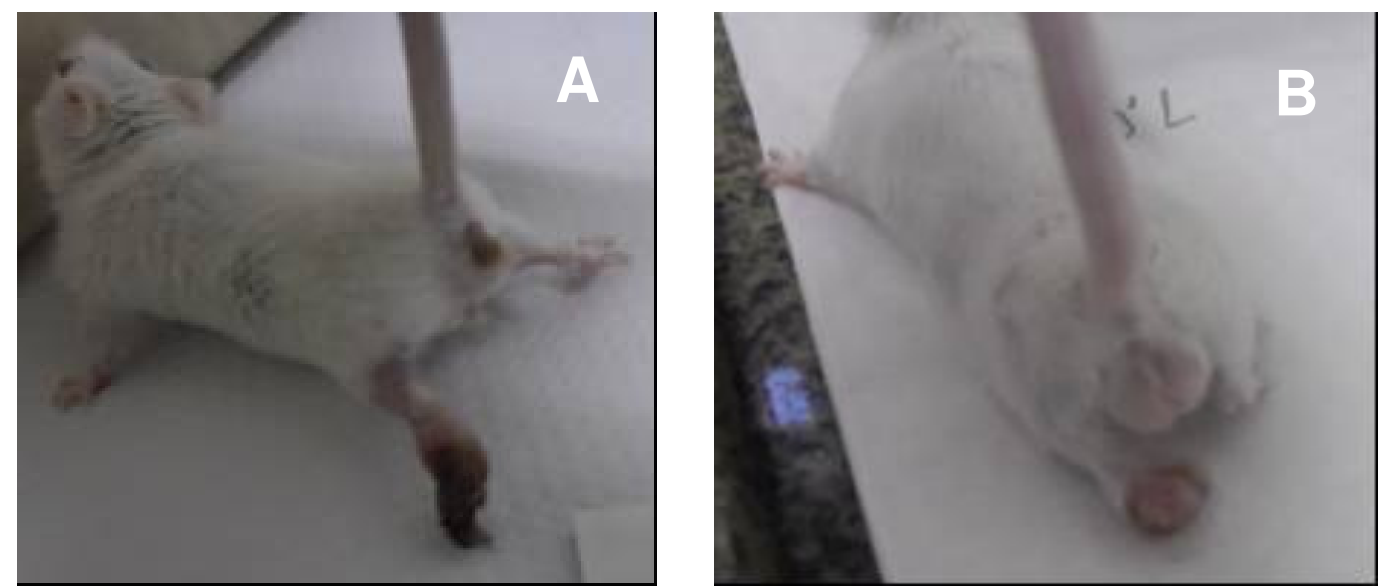

FIGURA 93 - Grupo 3 redução da lesão cutânea na pata dos camundongos ( A e B) tratados com PVAl/PVP/glucantime.

Para 0 grupo de animais tratados com a membrana PVAI/PVP/1,5\%argila/glucantime, são perceptíveis as mudanças significativas como as apresentadas nas FIG. 94 (A e B) e FIG. 95 (A e B) com redução de 95\% das lesões. Observou-se evolução significativa da redução das lesões durante o tratamento dos modelos experimentais com as membranas de PVP/PVAl/argila $1,5 \%$, hidratando a matriz do curativo com soro fisiológico após $24 \mathrm{~h}$.
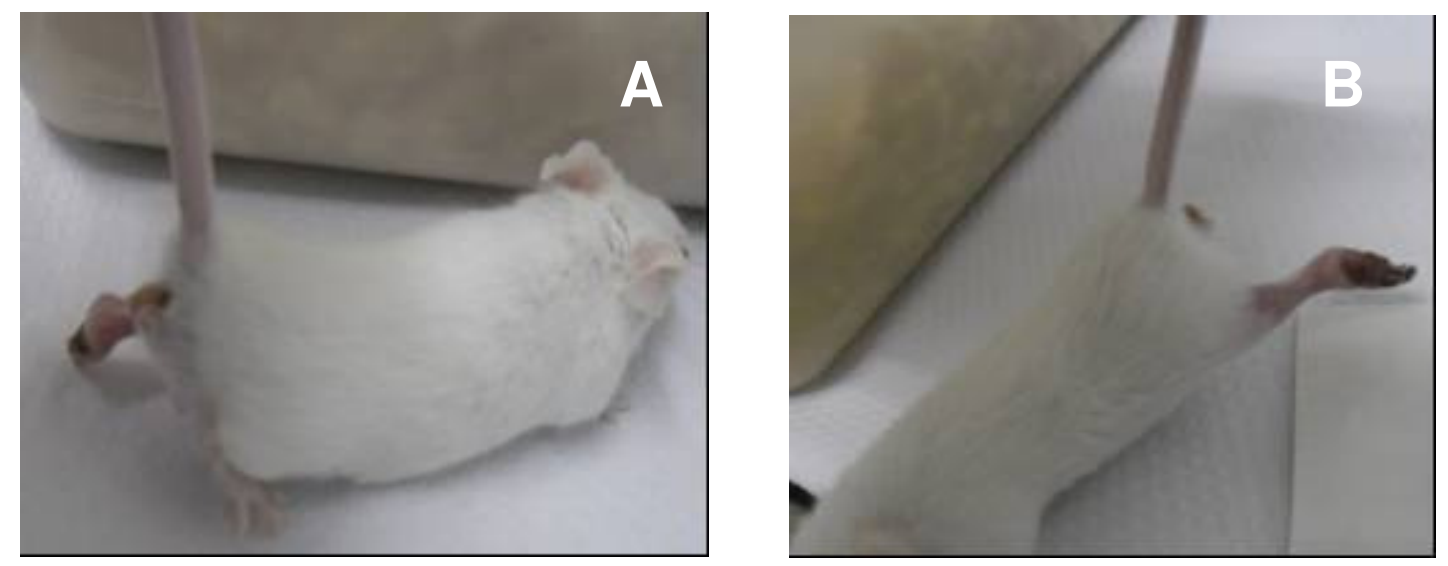

FIGURA 94 - Grupo 3 redução da lesão cutânea na pata dos camundongos (A e B) tratados com PVAI/PVP/1,5\% de argila / glucantime. 

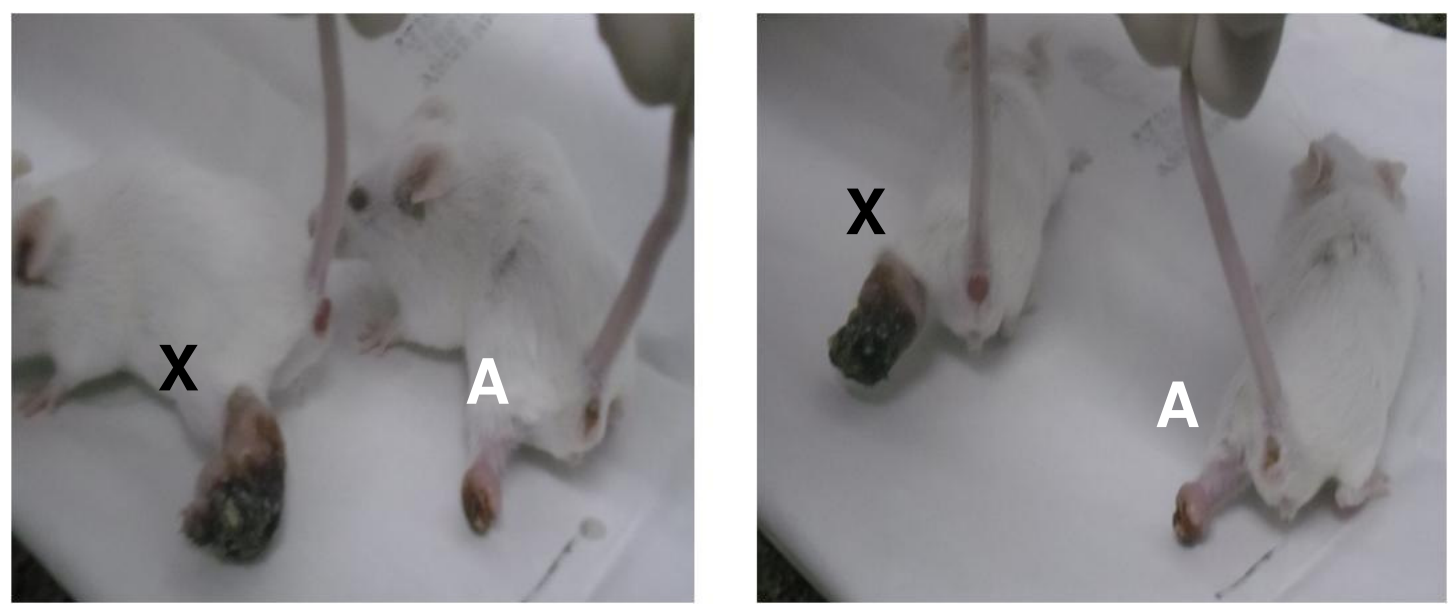

FIGURA 95 - Grupo 3 redução da lesão cutânea na pata dos camundongos (X controle sem tratamento) versus (A tratados com PVAI/PVP/1,5\% de argila/glucantime.

A TAB. 17 apresenta o resumo dos grupos de camundongos Balb/C tratados com hidrogéis com e sem glucantime, adotando-se a concentração de 2,3 mg de antimônio em cada curativo para o grupo $1^{\circ}$ e $2^{\circ}$ e a concentração de 6,9 mg de antimônio em cada curativo para o $3^{\circ}$ grupo. 
TABELA 17 - Resumo dos grupos de camundongos Balb/C tratados com e sem glucantime.

\begin{tabular}{|c|c|c|c|}
\hline $\begin{array}{l}\text { Grupos de } \\
\text { camundongos } \\
\text { Balb/C }\end{array}$ & $\begin{array}{l}\text { Tratados com } \\
\text { membranas de PVAl/ } \\
\text { PVP }\end{array}$ & $\begin{array}{l}\text { Tratados com } \\
\text { membranas de } \\
\text { PVAl/PVP / 1,5\% } \\
\text { glucantime }\end{array}$ & $\begin{array}{l}\text { Tratados com } \\
\text { membranas de } \\
\text { PVAl /PVP/1,5\% } \\
\text { argila / glucantime. }\end{array}$ \\
\hline $\begin{array}{c}1^{\circ} \\
2,3 \mathrm{mg}(\mathrm{SbV})\end{array}$ & $\begin{array}{l}\text { Não houve regressão } \\
\text { no tamanho das } \\
\text { lesões em nenhum } \\
\text { dos animais }\end{array}$ & $\begin{array}{l}\text { Houve regressão } \\
\text { de } 50 \% \text { do } \\
\text { tamanho das } \\
\text { lesões na } 3^{\underline{a}} \\
\text { semana em três } \\
\text { animais }(3 / 4)\end{array}$ & \\
\hline $\begin{array}{c}2^{\circ} \\
2,3 \mathrm{mg}(\mathrm{SbV})\end{array}$ & & & $\begin{array}{lr}\text { Houve regressão } \\
\text { de } 70 \% & \text { do } \\
\text { tamanho } & \text { das } \\
\text { lesões na } & 3^{\text {a }} \\
\text { semana em } & \text { dois } \\
\text { animais }(2 / 4) & \end{array}$ \\
\hline $\begin{array}{c}3^{\circ} \\
6,9 \mathrm{mg}(\mathrm{SbV})\end{array}$ & & $\begin{array}{l}\text { Membrana } \\
\text { PVAl/PVP/ } \\
\text { /glucantime } \\
\text { Houve regressão } \\
\text { de } 70 \% \text { do } \\
\text { tamanho das } \\
\text { lesões na } 3^{\text {a }} \\
\text { semana em três } \\
\text { animais }(3 / 4)\end{array}$ & $\begin{array}{l}\text { Houve regressão } \\
\text { de } 98 \% \text { do } \\
\text { tamanho das } \\
\text { lesões na } 3^{\underline{a}} \\
\text { semana em três } \\
\text { animais }(3 / 4)\end{array}$ \\
\hline
\end{tabular}

As demais membranas não foram testadas para este estudo. $O$ progresso terapêutico observado com os curativos demonstrou a aplicabilidade de membranas de hidrogéis contendo fármaco encapsulado para o uso tópico no tratamento de leishmaniose de acordo com os resultados obtidos nos testes "in vivo". 


\section{CONCLUSÕES}

O comportamento das curvas de intumescimento e da fração gel das membranas de hidrogéis analisadas podem ser justificadas de acordo com a formulação das amostras. Observou-se que a variação da porcentagem da argila interferiu no comportamento tanto do intumescimento quanto da fração gel para todos os sistemas estudados.

$\mathrm{Na}$ análise térmica foi observada uma mínima intensificação da estabilidade térmica para alguns dos sistemas com argila, com deslocamento de temperatura indicando a interação do polímero na argila.

Nas curvas de espectroscopia vibracional na região do infravermelho para o sistema PVP/PVAl/argila não foram observadas mudanças significativas, enquanto nos outros sistemas foram observados deslocamentos de picos característicos indicando a interação do polímero/argila.

As interações polímero argila analisadas por difração de raios $\mathrm{x}$ são resultantes de intercalação para 0 sistema PVP/argila e para 0 PVP/quitosana/argila 1,5\%, e nos demais sistemas houve a esfoliação.

Segundo as micrografias MEV obtidas com 1,0 \% de argila, foram observados vários microporos de formas aleatórias para todos os sistemas. Apenas o sistema PVP/PVAl $/ 1,0 \%$ de argila apresentou lacunas e microporos de forma organizada. Enquanto as amostras de todos os sistemas com 1,5\% de argila apresentaram aglomerações de argila em escala nanométrica em algumas regiões.

Observou-se por MFA o mapeamento de nanopartículas da argila nas membranas liofilizadas com regiões de argila dispersa nanometricamente e regiões com aglomerados. 
Por EDS também foram observadas aglomerações de argila em algumas regiões. Por essa técnica foi possível quantificar os íons da argila e o Sb na superfície de fratura para todas as amostras, nas quais se verificou a distribuição homogênea de antimônio nas membranas.

Nos testes de citotoxicidade "in vitro" realizados com células de mamíferos, os hidrogéis nanoestruturados com nanopartículas de argila não apresentaram citotoxicidade provando que as membranas podem ser usadas como suporte para a liberação do fármaco.

Observou-se que a liberação do fármaco glucantime (antimônio como princípio ativo) ocorre na extração no modo dinâmico, quanto para a liberação no modo estático de todos os sistemas. Mantendo-se o equilíbrio de liberação após as $6 \mathrm{~h}$ com algumas variações de acordo com a formulação das membranas e com liberação do fármaco relativamente mais lenta para os sistemas com quitosana.

A aplicação das membranas feita em forma de curativos foi realizada "in vivo" no tratamento das lesões cutâneas provocadas pela Leishmania amazonensis. As membranas de hidrogel de PVAl/PVP/argila1,5\%/glucantime e PVAl/PVP/glucantime assim aplicadas tiveram evidente contribuição para a redução do ferimento alcançando uma cura clínica.

Esse suporte de investigação poderá contribuir para uma terapia alternativa em humanos com a finalidade de aumentar a qualidade de vida do paciente, que não pode usar o medicamento de forma convencional devido aos efeitos colaterais. 


\section{PERSPECTIVAS FUTURAS}

- Investigar a eficiência das membranas de PVAl/PVP/argila no tratamento alternativo de pacientes com as lesões cutâneas causadas por leishmaniose.

- Testes "in vivo" para os demais sistemas estudados.

- Investigação da argila como carregador de fármaco por troca catiônica para liberação de outros fármacos e suas interações com a matriz polimérica.

- Investigação das membranas de hidrogéis para tratamentos de outros tipos de lesões.

- Testes "in vivo" com outros medicamentos. 


\section{REFERÊNCIAS BIBLIOGRÁFICAS}

ABBASPOUR, A.; NAJAFI, M.; KAMYABI, M. A. Quantitative kinetic determination of $\mathrm{Sb}(\mathrm{V})$ and $\mathrm{Sb}(\mathrm{III})$ by spectrophotometric H-point standard addition method, Anal. Chim. Acta. v. 505, p. 301-305, 2004.

ABD EI-MOHDY, H. L.; Ghanem S. Biodegradability, antimicrobial activy and properties of PVA/PVP hydrogels prepared by $\mathrm{Y}$-irradiation, J. Polym. Res. V. 16, p. 1-10, 2009.

AMATO, V. S.; TUON, F. F.; GRAF, M. E.; SIQUEIRA, A. M.; NICODEMO, A. C.; NETO, A. V. Treatment of New World cutaneous leishmaniasis - a systematic review with a meta-analysis, Int. J. Derm. v. 47, n 2, 109-124, 2008.

AMATO, V. S. TUON, F. F.; NETO, V. A. Leishmania: origin, evolution and future since the Precambrian FEMS, Immunol. Med. Microbiol. v. 54 p. 158-166, 2008.

AMATO, V. S. OLIVEIRA, L. S.; SILVA, A. C. M.; MACHADO, F. R.; AMATO, J. G. P.; NICODEMO, A. C.; AMATO N. V. A case of American tegumentar leishmaniasis successfully treated with low dose of pentavalent antimonial, Rev. Soc. Bras. Med. Trop. v. 31 n 2, 1998.

ANSEL, H. C.; POPOVICH, N. G.; ALLEN, L. V. Farmacotécnica: formas farmacêuticas e sistemas de liberação de fármacos, Artmed, p. 283-298, 2007.

ARANHA, I. B. ; ELIZABETE, F. L. Poli(Álcool Vinílico) Modificado com Cadeias Hidrocarbônicas: Avaliação do Balanço Hidrófilo/Lipófilo Polímeros, v. 11, n 4, p. 174-181, 200.

ASTM D 570 - American Society for Testing and Materials - Test method of test for water absorption of plastics, 2010.

ASTM D 2765 Standard Test Methods for Determination of Gel Content and Swell Ratio of Crosslinked Ethylene Plastics, 2001.

ATTA, A. M.; ELSAYED, A. M.; SHAFY, H. I. Uses of electron-beam irradiation to prepare $\mathrm{pH}$ and temperature-sensitive hydrogels from reactive poly(vinyl alcohol) grafts, J. Applied Polym. Sci. v. 108, p. 1706-1715, 2008.

BAYER, C. L.; PEPPAS N. A., Advence in recognitive, conductive and responsive delivery systems, J. Controlled Release, v. 132, p. 216-221, 2008. 
BASANO, S. A.; CAMARGO, L. M. A. American Cutaneous Leishmaniasis: history, epidemiology and prospects for control. Rev. Bras. Epidem. v. 7, $\mathrm{n}$ 3, 2004.

BAVARESCO, V. P.; MACHADO, L. D. B.; ZAVAGLIA, C. A. C.; REIS, M. C. Caracterização mecânica de hidrogéis de PVAI para serem utilizados como cartilagem artificial reticulados por irradiação. Rev. Bras. Pesq. Desenvol. v. 4 n 3, p. 1679-1681, 2002.

BENAMER, S.; MAHLOUS, M.; BOUKRIF, A.; MANSOUURI, B.; LYOUCE, F. S. Synthesis and Characterizations of Hydrogels Based on Poly(vinyl pyrrolidone), Nucl. Instrum. Methods Phys. Res. v. 248, p. 284-290, 2006.

BERMAN, J. D. Chemotherapy for Leishmaniasis: Biochemical Mechanism, Clinical, Efficacy and Future Strategies. Int. J. Infect. Diseases, v. 10, p. 560-686, 1988.

BERGER, J.; REIST, M.; MAYER, J. M.; FELT, O.; GURNY, R. Structure and interaction in chitosan hydrogels formed by complexation or aggregation for biomedical applications. Eur. J. Pharm. Biopharm. v. 57, p. 35-52, 2004.

BHATTARAI, N.; GUNN, J.; ZHANG M. Chitosanbased hydrogels for controlled, localized drug delivery. Adv. Drug. Deliv. Rev. v. 62, p. 83-99, 2009.

Biblioteca Virtual em Saúde, Ministério da Saúde, Disponível em 07 de julho de 2008, (http://bvsms.saude.gov.br/html/pt/dicas/126leishmania).

Boletim Técnico. GAF CORPORATION, Pasdone K-90.

BUENGER, D.; TOPUZ, F.; GROLL, J. Hydrogels in sensing applications, Prog. Polym. Sci. v. 37, p. 1678-1719, 2012.

CAMPANA, P. S. F.; SIGNINI, R. Efeito de Aditivos na Desacetilação de Quitina, Polímeros, v. 11, p. 169-173, 2001.

CARRETERO, M. I. Clay minerals and their beneficial effects upon human health, Appl. Clay Sci. v. 21, p. 155-163, 2002.

CARRADO, K. A., Polymer-clay Nanocomposites, Advanced Polymeric Materials-structure Property Relationships, chapter 10, 2003.

CATALANI, L. H.; FECHINE, G. J. M.; BARROS, J. A. G. Poly(N-vinyl-2 pyrrolidone) hydrogel production by ultraviolet radiation: new methodologies to accelerate crosslinking, Polymer, v. 45, p. 4705-4709, 2004.

CGEE. Centro de Gestão e Estudos Estratégicos, Materiais Avançados para Saúde Médiaca-odontológica, Ciência, Tecnologia e Inovação, v. 15, p. 297-331, 2010.

CHAPIRO, A. Future of radiation processing of polymers - Panel discussion, Radiat. Phys.Chem., v. 35, p. 15-17, 1990. 
CHAPIRO, A. Polymer irradiation: past-present and future, Radiat. Phys. Chem., v. 63, p. 207-209, 2002.

CHMIELEWSKI, A. G.; CHMIELEWSKA, D. K.; MICHALIK, J.; SAMPA, M. H. Prospects and challenges in application of gamma, electron and ion beams in processing of nanomaterials, Nucl. Instrum. Methods Phys. Res. v. 265, p. 339-346, 2007.

CLARKE, G. M. Specialty Clays, Industrial Minerals \& Rocks, p. 25-52, 1985.

COELHO, A.; VIEIRA, C.; SANTOS, P. S.; SANTOS, H. S. Argilas Especiais: O que são Caracterização e Propriedades. Quím. Nova, v. 30, n 1, 146-152, 2007.

Conferência Nacional de Ciência, Tecnologia e Inovação em Saúde, Anais, $2^{a}$, Brasília-DF - 2004.

DANIEL, J. S.; KRZYSZTOF, M.; JUNG, K. O. Ray Drumright. The development of microgels/nanogels for drug delivery applications, Prog. Polym. Sci. v. 33, p. 448-477. 2008.

DE PAOLI, M. A. Degradação e Estabilização de Polímeros, Formas Independentes de iniciação das Reações de Degradação Chemical, Cap. 3, 2008.

DASH, M.; CHIELLINI, F. OTTENBRITE, R. M, CHIELLINI, E, Chitosan-A versatile semisynthetic polymer in biomedical applications Prog. in Polym. Sci. v. 36, p. 981-1014, 2011.

DUMITRIU, S. Polymeric Biomaterials, Marcel Dekker, New York, chapter 16, 1994.

ETXEBERRIA, A.; IRUIN, J. J.; UNANUE, A.; IRIONDO, P. J.; FERNANDEZBERRIDI, M, J.; MARTINEZ, I. A. miscibility windows of poly(vinyl methyl ether) with modified phenoxy resin, Eur. Polym. J. v. 37, n 10, p. 1943-1950, 2001.

FELTO, B. P.; GURNY, R. Chitosan: a unique polysaccharide for drugdelivery. Drug. Dev. Ind. Pharm. v. 24, p. 979-93, 1998.

FIOCRUZ Fundação Oswaldo Cruz, Consultado em Novembro de 2012. (http://www.degeo.ufop.br/laboratorios/microlab/mev.htm).

GHAFFARIFAR, F. Leishmania major: In vitro and in vivo anti-leishmanial effect of contharidin, Exp. Parasitol. J. v. 126, p. 126-129, 2010.

FONSECA, M. G.; AIROLDI, C.Híbridos inorgãnicos-Orgânicos derivados da reação de filossilicatos com organossilanos, Quím. Nova, v. 26, n 5, 2003.

GODOVSKY, D. Y. Device Applications of Polymer - Nanocomposites, v. 153, Adv. Polym. Sci. v. 68, p. 439-447, 2000. 
GONTIJO, C. M. F.; MELO, M. N. Leishmaniose Visceral no Brasil, Rev. Bras. Epidemiol. v. 7, n 3, 2004.

GONTIJO, B.; CARVALHO, M. L. R. Leishmaniose Tegumentar Americana. In: Rev. Soc. Bras. Med. Trop. v. 36, p. 71-80, 2003.

GUERRA, J. A . O.; PRESTES, S. R.; SILVEIRA, H.; COELHO, L. I. A. R. C.; GAMA, P.; MOURA, A.; AMATO, V. ; BARBOSA, M. G. V.; FERREIRA, L. C. L. Mucosal Leishmaniasis Caused by Leishmania (Viannia) braziliensis and Leishmania (Viannia) guyanensis in the Brazilian Amazon, J. List. PLoS. Negl. Trop. v. 5, 2011.

GUPTA, K. C.; JABRAIL, F. H. Glutaraldehyde Cross-Linked Chitosan Microspheres for Controlled Release of Centchroman, Carbohydr. Res. v. 342, p. 2244-2252, 2007.

GÜVEN, O; HAJI-SAEID, M.; SAMPA, M. H.; RAMAMOORTHY, N.; CHMIELEWSKI, A. G. The role of IAEA in coordinating research and transferring technology in radiation chemistry and processing of polymers, Nucl. Instrum. Methods Phys. Res. v. 265 p. 51-57, 2007.

HASSAN, C. M.; PEPPAS, N. A. Structure and Applications of Poly(vinyl alcohol) Hydrogels Produced by Conventional Crosslinking or by Freezing/Thawing Methods, Polym. Sci. v. 153, p. 37-65, USA, 2000.

HOFFMAN, A. S. Hydrogels for biomedical applications, Advanced Drug Delivery, v. 64, p. 18-23, 2012.

HOARE, R. T.; KOHANE, D. S. Hydrogels in drug delivery: progress and challenges, Polym. v. 49, p. 1993-2007, 2008.

IKADA, Y. BURCZAK, K.; FUJISATO, T.; HATADA, M. Protein permeation trough poly(vinyl alcohol) hydrogel, Biomaterials, v.15, p. 231238, 1994.

INOKUTI M. Remarks on stopping power: Its connections with particle transport and with the electronic structure of matter. Int J Quantum Chem. v. 57, p. 173-82, 1996.

INTERNATIONAL ATOMIC ENERGY AGENCY. Radiation Safety of Gamma and Electron Irradiation Facilities IAEA Safety Series n 107, Vienna Austria, 1992.

JACOBINA, R. R; MOREIRA, J.; GELMAN, E. A. A Gazeta Medica da Bahia, História, Ciências, Saúde - Manguinhos, v. 15, n 4, p. 1077-1097, 2008.

JAGUR-GRODZINSKI, J. Polymeric gels and hydrogels for biomedical and pharmaceutical applications, Polym. Adv. Technol. v. 21, p. 27-47, 2010.

JAIN, A. K.; THOMAS, N. S.; PANCHAGNULA, R. Transdermal drug delivery hydrochloride, J. Controlled Release. v. 79, p. 93-101, 2002. 
JAYAKUMAR, R.; PRABAHARAN, M. , REIS, R. L.; MANO, J. F. Graft copolymerized chitosan-present status and applications Carbohyd Polym, v. 62 , p. $142-158,2005$.

JAUHARI, S.; DASH, A. K. A mucoadhesive in situ gel delivery system for paclitaxel. AAPS Pharm. Sci. Tech. v. 7, p. 531-536, 2006.

JESZKA, J.; KADLUBOWSKi S.; ULANSKI P. Simulations of nanogels formation by intramolecular recombination of radicals on polymer chaim. Macromol. v. 39, p. 857-870, 2006.

JING, X. B. YU , H.; XU, X.; CHEN, X.; LU, T.; ZHANG, P. Preparation and antibacterial effects of PVA-PVP hydrogels containing silver nanoparticles, $\mathbf{J}$. Appl. Polym. Sci. v.103, p.125-133, 2007.

JOUNG, Y. K.; CHOI, J. H.; PARK, K. M.; PARK, K. D. PLGA microparticle embedded thermosensitive hydrogels for sustained release of hydrophobic drugs. Biomed. Mater. v. 2, p. 269-73, 2007.

KADLUBOWSKI, S.; GROBELNY, J.; OLEJNICZAK, W.; CICHOMSKI, M.; ULANSKI, P. Pulses of fast electrons as a tool to synthesize poly(acrylic acid) nanogels: Intramolecular cross-linking of linear polymer chains in additive-free aqueous solution, Macromol. v. 36, p. 2484-2492, 2003.

KAWASHIMA, Y. Preface nanoparticulate systems for improved drug delivery. Adv. Drug Delivery Rev. v. 1, n 47, p. 1-2, 2001.

KATO, Y, ONISHI, H, MACHIDA, Y. Evaluation of N-succinyl-chitosan as a systemic long- circulating polymer, Biomaterials, v. 21, p. 1579-1585, 2000.

KIM, S. W.; BAE, Y. H. OKANO, T. Hydrogels: swelling, drug loading, and release. Pharm. Res. v. 9, p. 283-90, 1992.

LAKOURAJ, M. M.; TAJBAKHSH, M.; MOKHTARY, M. Synthesis and swelling characterization of cross-linked PVP/PVA hydrogels, Polym. J. v. 14, p. 1022-1030, 2005.

LANGALY, G. Pesticide-clay interactions and formulations, Appl. Clay Sci. v. 18, p. 205-209. 2001.

\section{LAPONITE PERFORMANCE ADDITIVE, (www.laponite.com).}

LEE, J. H.; SIDDARAMAIAH, LI, P.; KIM, N. H.; YOO, G-H. Poly(acrylamide/laponite) nanocomposite hydrogels: Swelling and cationic dye adsorption properties, J. Applied Polym. Sci. v. 111, p. 1786-1798, 2009.

LEE, K. Y.; MOONEY, D. J. Hydrogels for tissue engineering, Chem. Revs, v. 101 p. 1869-1879, 2001.

LEE, J. E, KIM, S. E.; KWON, I. C.; AHN, H. J.; CHO, H.; LEE, S. H.; KIM, H. J.; SEONG, S. C. LEE, M. C. Effects of a chitosan scaffold containing 
TGFbeta1 encapsulated chitosan microspheres on in vitro chondrocyte culture. Artif. Organs. v. 28, p. 829-39, 2004.

LIMA, K. M.; SILVA, C. L.; RODRIGUES-JÚNIOR, J. M. Microesferas biodegradáveis, Biotecnol. Ciência Desenvol. v. 2, p. 10-13, 2000.

LIN, C. C.; ANSETH, K. S. PEG hydrogels for the controlled release of biomolecules in regenerative medicine, Pharm. Res. v. 26, p. 631- 43, 2009.

LÓPEZ-GALINDO, A.; VISERAS, C.; CEREZO, P.; Compositional, technical and safety specifications of clays to be used as pharmaceutical and cosmetic products, Appl. Clay Sci. v. 36, p. 51-63, 2007.

LOPÉRGOLO, L. C.; LUGÃO, A. B.; CATALANI, L. H. Direct UV photocrosslinking of poly(N-vinyl-2-pyrrolidone) (PVP) to produce hydrogels, Polym. v. 44, p. 6217-6222, 2003.

LOZINSKY, V. I.; DAMSHKALN, L. R.; BROWN, G.; NORTON, I. T. Study of cryostructuration of polymer systems. XVI. Freeze-thaw-induced effects in the low concentration systems amylopectin-water, J. Appl. Polym. v. 75, p. 1740-1748, 2000.

LUGÃO, A. B.; ZULLI, G.; LOPES, P. S.; VELASCO, M. V. R.; ALCANTARA, M. T. S.; ROGERO, .S. O.; MATHOR, M. B. Influence of gamma radiation onto polymeric matrix with papain, Radiat. Physics Chem. v. 79, p. 286288, 2010.

LUGÃO, A. B.; HIGA, O. Z.; ROGERO, S. O.; MACHADO, L. D. B.; MATHOR, M. B.; Biocompatibility study for PVP wound dressing obtained in different conditions, Radiat. Phys. Chem. v. 55, p. 705-707, 1999.

LUTOLF, M. P.; HUBBELL, J. A. Synthetic biomaterials as instructive extracellular microenvironments for morphogenesis in tissue engineering. Nat. Biotechnol. v. 23, p. 47-55, 2005.

MANSUR, H. S.; SADAHIRA, C.M,; SOUZA, A.; MANSUR, A. A. P. FTIR spectroscopy characterization of poly(vinyl alcohol) hydrogel with different hydrolysis degree and chemically crosslinked with glutaraldehyde, Mater. Sci. Eng. C. v. 28, p. 539-548, 2007.

MANSUR, H. S.; EZEQUIEL, S. C. Jr. Preparação e Caracterização de Blendas de Quitosana/Poli(álcool vinílico). Reticuladas Quimicamente com glutaraldeído para Aplicação em Engenharia de Tecido Quím. Nova, v. 31, n 6, 1460-1466, 2008.

Manual de Vigilância da Leishmaniose Tegumentar Americana, Série A. Normas e Manuais Técnicos 2. a edição atualizada, 2007.

MARSDEN, P. D., Pentavalent antimonials: old drugs for new diseases. Rev. Soc. Bras. Med. Trop. v. 18, 187-198, 1985. 
MARCONI, W.; BENVENUTI, F.; PIOZZI, A. Covalent bonding of heparin to a vinyl copolymer for biomedical applications, Biomaterials, v. 18, 885, 1997.

MERCIER, L.; DETELLIER, C. Preparation, characterization and applications as heavy metals sorbents of covalently grafted thiol functionalities on the interlamellar surface of montmorillonite. J. Environ. Sci. Technol. J. Environ. Sci. Health, Part B v. 29, p. 1318-1323, 1995.

MINFENG, Z. XUDONG, S.; YUN, W.; XIANDONG, Y.; HUIQUAN, X. ; W. $\mathrm{BAOYI}$, Correlations between the free-volume properties and the miscibility of chitosan/polar polymers blend membranes, Radiat. Phys. Chem. v. 77, p. 1062-1068, 2008.

MOHAMAD AL-SHEIKHLY, Oral presentation, International Nuclear Atlantic Conference, 2008.

NGAH, W. S. W.; KAMARI, A.; KOAY, Y. J. Equilibrium and kinetics studies of adsorption of copper (II) on chitosan and chitosan/PVA beads, Int. J. Biol. Macromol. v. 34, p. 155-161, 2004.

NAIR, S. H.; PAWAR, K. C.; JOG, J. P.; BADIGER, M. V. Swelling and Mechanical Behavior of Modified Poly(vinyl alcohol)/Laponite Nanocomposite Membranes, J. Appl. Polym. Sci. v. 103, p. 2896-2903, 2007.

NETO, C. G. T. Permeability studies in chitosan membranes. Effects of crosslinking and poly(ethylene oxide) addition. Carbohydr. Res. v. 340, p. 2630-2636, 2005.

NORMA, N. H.; LETOFFE, J-M.;. REYMOND, J-P;. BOURGEAT-LAM, E. Silylation of laponite clay particles with monofunctional and trifunctional vinyl alkoxysilanes, J. Mater. Chem. v. 15, p. 863-871, 2005.

OBARA, K.; ISHIHARA, M.; OZEKI, Y.; ISHIZUKA, T.; HAYASHI, T.; NAKAMURA, S.; SAITO, Y.; YURA, H.; MATSUI, T.; HATTORI, H.; TAKASE, B.; ISHIHARA, M.; KIKUCHI, M.; MAEHARA, T. Controlled release of paclitaxel from photocrosslinked chitosan hydrogels and its subsequent effect on subcutaneous tumor growth in mice. J. Control Release, v.110, p. 79-89, 2005.

OLIVEIRA, M. J. A. Síntese, Caracterização e Citotoxicidade de Hidrogéis Poliméricos Para Imobilização de Fármaco Empregado no Tratamento de Leishmaniose, Dissertação apresentada como parte dos prequisitos para obtenção do Grau de Mestre em Ciências na Área de Tecnologia NuclearMateriais, IPEN-SP, 2008.

ONUKI, Y.; BHARDWAJ, U.; PAPADIMITRAKOPOULOS, F.; BURGESS, D. J. A. Review of the Biocompatibility of Implantable Devices: Current Challenges to Overcome Foreign Body Response, J. Diabet. Sci. Technol. v. 2, n 6, 1003-1015, 2008. 
PEPPAS, N. A.; STAUFFER S. R. Reinforced uncrosslinked poly(vinyl alcohol) gels produced by cyclic freezing-thawing process, J. Controlled Release, v.16, p. 305-310, 1991.

PEPPAS, N. A.; HILT, J. Z.; KHADEMHOSSEINI, A.; LANGER, R. Hydrogels in biology and medicine: from molecular principles to bionanotechnology, Advanced Mater. v. 18, p. 1345-1360, 2006.

PEPPAS, N. A.; THOMAS, J. B.; SATO, M.; WEBSTER, T. J. Nanotechnology and Biomaterials in Nanomaterials Handbook, Boca Raton, chapter 22, p. 605-636, 2006.

PEPPAS, N. A.; CHANG, J. Y.; GODOVSKY, D. Y.; HAN, M. J.; HASSAN, C. M..; KIN, J.; LEE, B.; LEE, Y. Biopolymers PVA Hydrogels Anionic Nanocomposites, Adv. Polym. Sci. Springer, 2000.

PEPPAS, N. A. "Hydrogels in Medicine and Pharmacy", v. III, CRC PRESS Boca Raton, 1987.

PEPPAS, N. A.; MERRILL, E. W. Crossilinked Poly(vinyl alcohol) Hidrogels as Swollen Elastic Networks, J. Appl. Polym. Sci., v. 21, p. 1763-1770, 1977.

PEPPAS, N. A.; MERRILL, E. W. Development of Semicrystalline Poly(vinylalcohol) Hydrogels for Biomedical Applications, J. Biomed. Mater. v.11, p. 423-434, 1977.

PEPPAS, N. A.; LIECHTY, W. B.; CALDORERA-MOORE, M.; PHILLIPS, M. A.; SCHOENER; C. Advanced molecular design of biopolymers for transmucosal and intracellular delivery of chemotherapeutic agents and biological therapeutics, J. Controlled Release, v, 155, p. 119-127, 2011.

PEPPAS, N. A.; HOFFMAN, A. S. Hydrogels, Biomaterials Science, cap. 1.2.3. p. 166-179, 2013.

PERGHER, S. B. C. Materiais laminares pilarizados: preparação, caracterização, propriedades e aplicações. Erechim: Ed. FAPESP, 2005.

PETERSEN, L. K. Narasimhan B. Combinatorial design of biomaterials for drug delivery: opportunities and challenges. Expert. Opin. Drug. Deliv. v. 5, p. 837-846, 2008.

PRONIN,T.[http://noticias.uol.com.br/saude/ultimasnoticias/redacao].De 2000 para cá, leishmaniose visceral matou mais que a dengue em nove Estados. Publicado em novembro de 2012.

QIGANG, W.; JUSTIN, L. M.; MASAR, Y.; EUNJI, L.; MYONGSOO, L.; KOU O.; KAZUSHI, K.;TAKUZO, A. High-water-content mouldable hydrogels by mixing clay and a dendritic molecular binder, Nature, v. 463, p. 339-343, 2010. 
RATH, S.; TRIVELIN, L. A.; IMBRUNITO, T. R.; TOMAZELA, D. M.; JESÚS. M. N.; MARZAL, P. M. Antimoniais empregados no tratamento da leishmaniose, Quím. Nova, v. 26, p. 550-555, 2003.

ROGERO, S. O.; MALMONGE, S.; LUGAO, A. B.; IKEDA, T. I ; MIYAMARU, L.; CRUZ, A. S . Biocompatibility study of polymeric biomaterials, Artificial Organs, v. 27, p. 424-427, 2003.

RODRIGUES, F. Princípios de sistema de Polímeros, EL Manual Moderno, S. A. De, México, 1984.

ROSIAK, J. M.; KADLUBOWSKI, S.; ULANSKI, P. Synthesis of tailored nanogels by means of two-stage irradiation, Polymer, v. 53, p. 1985-1991, 2012.

ROSIAK, J. M. KADLUBOWSKI, S.; HENKE, A.; ULANSKI, P. Hydrogels of polyvinylpirrolidone (PVP) and poly(acrylic acid) (PAA) synthesized by radiation-induced crosslinking of homopolymers, Nucl. Instrum. Methods Phys. Res. v. 79, p. 261-266, 2010.

ROSIAK, J. M.; OLEJNICZAK, J. Medical Applications of Radiation Formed Hydrogels, Radiat. Phys. Chem. v. 42, p. 903-906, 1993.

ROSIAK, J. M.; JANIK, I.; KADLUBOWSKI, S.; KOZICKI, M.; KUJAWA, P.; STASICA, P.; ULANSKI, P. Nano-, micro- and macroscopic hydrogels synthesized by radiation technique, Nucl. Instrum. Methods. Phys. Res. v. 208, p. 325-330, 2003.

ROSIAK, J. M.; HENKE, A; KADLUBOWSKI , S.; ULANSKI , P.; ARNDT, K.-F. Radiation-induced ceross-induced cross-linking of polyvinylpirrolidone poly(acrylic acid) complexes, Nucl. Instrum. Methods Phys. Res., Sect. B. v. 239, p. 391-398, 2005.

ROSIAK, J. M.; NURKEEVA, Z. S.; KHUTORYANSKIY, V.; MUN, G. A.; BITEKENOVA, A. B.; KADLUBOWSKI, S.; SHILINA, Y. A.; ULANSKI, P. Interpolymer complexes of poly(acrylic acid) nanogels with some non-ionic polymeres in aqueous solutions, Colloids Surf. A. v. 236, p. 141-146, 2004.

ROSIAK, J. M.; ULANSKI, P. Synthesis of hydrogels by irradiation of polymers in aqueous solution, Radiat. Phys. Chem. v. 55, p. 139-151, 1998.

RUEL-GARIEPY, E, S, M.; BICHARA, A.; BERRADA, M.; LE, G. D.; CHENITE, A,; LEROUX, J. C. A thermosensitive chitosan based hydrogel for the local delivery of paclitaxel. Eur. J. Pharm. Biopharm. v. 57, p. 53-63, 2004.

RUIZ, J.; MANTECÓN, A.; CADIZ, V. Synthesis and swelling characterization of acid-containg poly(vinyl alcohol) hydrogels, J. Appl. Polym. Sci. v. 81, p. 1444-1450, 2001.

SILVA, A. R. V.; FERREIRA, H. C. Esmectitas organofílicas: conceitos, estruturas, propriedades, síntese, usos industriais e produtores/fornecedores 
nacionais e internacionais, Rev. Eletron. Mater. Proces. v. 3, p. 01-11, 2008.

SOKKER, H.; GHAFFAR, A. M. A,; GAD, Y. H.; ALY, A. S. Synthesis and characterization of hydrogels based on grafted chitosan for the controlled drug release. Carbohydr. Polym. v. 75, p. 222-229, 2009.

SOLANGER, R.; PEPPAS, N. A. Present and Future Applications of Biomaterials in Controlled Drug Delivery Systems, Biomaterials, v.2, p. 201214, 1981.

SOLANGER, R. Controlled Release of Macromolecules, Chemtech, v. 29, p. 98-105, 1982.

SUH, J. K. F.; MATTHEW, H. W. T. Application of chitosan-based polysaccharide biomaterials in cartilage tissue engineering: Biomaterials v. $21,2589,2000$.

SUNG, H. W.; HUANG, R. N.; HUANG, L. L. H.; TSAI, C. C.; CHIU, C. T. Crosslinking characteristics and mechanical properties of a bovine pericardium fixed with a naturally occurring crosslinking agent, J. Biomed. Mater. Res. Part. A. v. 47, p. 116-126, 1999.

TADMOR, Z.; GOGOS, C. G. Principles of Processing, John Wiley \& Sons New York. p. 43, 1979.

TAKAGI, K.; SAWAKI, Y. Photochemical reactions in organized and semi organized media. Insect. Biochem. Mol. Biol. v. 28, n 4, p. 323-367, 1993.

TESSMAR, J. K.; GOPFERICH, A. M. Matrices and scaffolds for protein delivery in tissue engineering. Adv. Drug. Deliv. Rev. v. 59, p. 274-91, 2007

TEIXEIRA-NETO, É.; TEIXEIRA-NETO, Â. A. Modificação química de argilas: desafios científicos e tecnológicos para obtenção de novos produtos com maior valor agregado Quím. Nova, v. 32, n 3, 809-817, 2009.

THENG, B. K. J. Formation and properties of clay-polymer complexes. Amsterdam: Elsevier, Cap. 4, p. 95-108, 1979.

TOMME, S. R. V.; STORM, G.; HENNINK, E. W. In Situ gelling hydrogels for pharmaceutical and biomedical applications, Int. J. Pharm. v, 355, p. 1-18, 2008.

ULANSKI, P.; ROSIAK, J. M.; JANIK, I.; KADLUBOWSKI, S.; KOZICKI, M.; KUJAWA, $P$.; STASICA, $P$. Nano-micro and macroscopic hydrogels synthesized by radiation technique, Nucl. Instrum. Methods Phys. Res. V. 208, p. 325-330, 2003.

ULANSKI, P. Polymeric Biomaterials Synthesized by radiating techniques corrent study at IARC, Polym. Adv. Techonol. v.13, p. 951-959, 2002. 
ULANSKI, P.; ROSIAK, J. M., Polymeric Nano/Microgels; Encyclopedia of Nanoscience and Nanotechnology, J. AM. CHEM. SOC. v. 8, p. 845-871, 2004.

ULANSKI, J. Molecular relaxations in radiationally crosslinked poly(vinyl methyl ether) hydrogels, J. Non-Cryst. Solids. v. 353, p. 4536-4540, 2007.

VILLEMURE, G. Photochemical applications of the intercalation of organic cations in clay minerals. Thesis (Phd of Chemistry) - University of Ottawa, 1987.

VILLANOVA, J. C. O.; RODRIGO, L. O.; ARMANDO, S. C. Aplicações Farmacêuticas de Polímeros, Polímeros, v. 20, p. 51-64, 2010.

VITALIY, V. K. Hydrogen-bonded interpolymer complexes as materials for pharmaceutical applications, Int. J. Pharm. v. 334 p. 15-26, 2007.

ZHENG, Q. H.; YU, A. B.; LU, G. Q.; PAUL, D. R. Clay-Based Polymer Nanocomposites: Research and Commercial Development, J. Nanosci. Nanotechnol. v. 5, p. 1574-1592, 2005.

ZIV, D.; MISHAEL, Y. G.; Herbicide solubilization in micelle-clay composites as a basis for controlled release sulfentrazone and metolachlor formulations. J. Agric. Food Chem, v 56, p. 9159-9165, 2008.

YANG, X.; LIU, Q.; CHEN, X.; ZHU, Z. Investigation on the formation mechanisms of hydrogels made by combination of $y$-ray irradiation and freeze-thawing, J. Polym. Sci. v. 108, p. 1365-1372, 2008.

YANO, H.; HIRAYAMA, F.; KAMADA, M.; ARIMA, H.; UEKAMA, K. J. Colonspecific delivery of prednisolone-appended alpha-cyclodextrin conjugate: alleviation of systemic side effect after oral administration. J. Controled Release, v. 79, p. 103-112, 2002.

WANG, T.; TURHAN, M.; GUNASEKARAN, S. Selected properties of $\mathrm{pH}-$ sensitive, biodegradable chitosan-poly(vinyl alcohol) hydrogel, Polym. Int. v. 53, p. 911-918, 2004.

WANG, D.; WILLIAMS, C. G.; YANG, F.; ELISSEEFF, J. H. Enhancing the Tissue-Biomaterial Interface: Tissue-Initiated Integration of Biomaterials, Adv. Funct. Mater. v. 14, p. 1152-1159, 2004.

WILLIAMS, D. F. Definitions in Biomaterials, In Progress in Biomedical Engnering. Chester, England Proceedings of a Concensus Conference of the European Society for Biomaterials, p. 3-5, 1986.

WOJNÁROVITS, L. Handbook of Nuclear Chemistry, Kluwer Academic Publishers, cap. 1, 2003.

(http://www.who.int/tdr/diseases/leish/diseaseinfo.htm). Consultado em: abril de 2008. 
(http://www.scprod.com/pdfs/Laponite\%20brochure\%20EN) Consultado em janeiro de 2013.

(http://www.bulas.med.br/bula/2792/glucantime.htm), consultado em janeiro de 2013.

(http://www.healthbeautysolutions.com/Polargel.asp). Consultado em Janeiro 2013.

(http://vigiar.blogspot.com.br/2011/07/leishmaniose-voce-sabe-do-que-setrata.html) Vigilância Ambiental leishmaniose, consultado junho 2013.

(http://www.quimica.com.br) Revista química e derivados, 2006. Consultado junho 2013.

http://parasitophilia.blogspot.com.br/2012/04/leishmania-mexicana.html. Consultado em abril, 2012.

\section{BIBLIOGRAFIA COMPLEMENTAR}

1 Inokuti M.

Radiation Physics and Chemistry, v. 38, p. 2999 (1963).

2 Peppas N. A., Merril E. W.

J. Polym. Sci., Polym. Chem., v. 14, p. 441 (1976).

3 Rosiak J., Olejniczak J., Charlesby A.

Radiation Physics and Chemistry, v. 32, p. 691-694, (1988).

4 Rosiak J., Olejniczak J., Pekala W.

Radiation Physics and Chemistry, v. 36, p. 747-755, (1990).

$5 \quad$ Ulanski P., Rosiak J.M.

Journal of Radioanalytical and Nuclear Chemistry, v.186, p. 315-324, (1994).

6 Rosiak J. M., Ulanski P., Rzeznicki.

Nuclear Instruments and Methods in Physics Research, v.105, p. 335339, (1995).

7 Rosiak J. M., Dec W., Kowalski. A. J. 
Medical Science Monitor, v. 2, p. 78, (1996).

8 Ulanski P., Bothe E., Hildebrand K., Von Sonntag C., Rosiak J. M.

Nukleonika, v. 42, p. 425-436, (1997).

9 Rosiak J. M.

Radiation Physics and Chemistry, v. 51, p. 13-17, (1998).

10 Ulanski P., Wojtasz-Pajak A., Rosiak J. M. C. von Sonntag C.

Advances in Chitin Science, v.4, p. 429, (2000).

11 Ulanski P., Kadlubowski S., Rosiak J. M.

Radiation Physics and Chemistry, v. 63, p. 533, (2002).

12 Rosiak J. M., Janik I., Kadlubowski S., Kozicki M., Kujawa P,. Stasica P., Ulanski P.

Nuclear Instruments and Methods in Physics Research, v. 208, p. 325330, (2003).

13 Kadlubowski S., Henke A., Ulanski P., Rosiak J. M., Bromberg L., Hatton T. A.

Polymer, v. 48, p. 4974-4981, (2007).

14 Pastorczak M., Kadlubowski S., Okrasa L., Kozanecki M., Boiteux G., Rosiak J., Ulanski J.

Journal of Non-Crystalline Solids, v. 353, p. 4536-4540, (2007).

15 Kadlubowski S., Henke A., Ulanski P., Rosiak J. M.

Radiation Physics and Chemistry, v.79, p. 261-266, (2010). 


\section{APÊNDICE}

As concentrações de antimoniato liberado pelas membranas de hidrogéis para o sistema B estão representadas nas TAB. 18; 19 e 20, modo dinâmico.

TABELA 18 - Concentração de antimoniato $\mu \mathrm{g} \mathrm{mL}^{-1}$ liberado pelas membranas de hidrogéis PVP/PVAl e PVP/PVAl/argila. Pela técnica de Espectrometria de Absorção Atômica com Atomização por Forno de Grafita (GF-AAS).

\begin{tabular}{lllll}
\hline Horas & Membranas & $\begin{array}{l}\text { Concentração } \\
\left(\mu \mathrm{mL}^{-1}\right)\end{array}$ & Membranas & $\begin{array}{l}\text { Concentração } \\
\left(\mu \mathrm{mL}^{-1}\right)\end{array}$ \\
\hline 3 & PVP/PVAl & $3,0 \pm 0,1$ & PVP/PVAl/argila & $7,2 \pm 0,1$ \\
5 & PVP/PVAl & $8,9 \pm 0,1$ & PVP/PVAl/argila & $8,7 \pm 0,1$ \\
7 & PVP/PVAl & $8,0 \pm 0,1$ & PVP/PVAl/argila & $9,5 \pm 0,1$ \\
9 & PVP/PVAl & $9,5 \pm 0,1$ & PVP/PVAl/argila & $10,3 \pm 0,2$ \\
12 & PVP/PVAl & $8,9 \pm 0,3$ & PVP/PVAl/argila & $10,2 \pm 0,1$ \\
24 & PVP/PVAl & $7,8 \pm 0,1$ & PVP/PVAl/argila & $11,0 \pm 0,1$ \\
48 & PVP/PVAl & $8,2 \pm 0,2$ & PVP/PVAl/argila & $10,9 \pm 0,1$ \\
\hline
\end{tabular}

TABELA 19 - Concentração de antimoniato $\mu \mathrm{g} \mathrm{mL}^{-1}$ liberado pelas membranas de hidrogéis PVAl/argila e PVP/argila. Pela técnica de Espectrometria de Absorção Atômica com Atomização por Forno de Grafita (GF-AAS).

\begin{tabular}{lllll}
\hline Horas & Membranas & $\begin{array}{l}\text { Concentração } \\
\left(\mu \mathrm{mL}^{-1}\right)\end{array}$ & Membranas & $\begin{array}{l}\text { Concentração } \\
\left(\mu \mathrm{mL}^{-1}\right)\end{array}$ \\
\hline 3 & PVAl/argila & $4,1 \pm 0,1$ & $\mathrm{PVP} /$ argila & $8,5 \pm 0,1$ \\
5 & $\mathrm{PVAl} /$ argila & $5,4 \pm 0,1$ & $\mathrm{PVP} /$ argila & $10,3 \pm 0,1$ \\
7 & $\mathrm{PVAl}$ /argila & $6,0 \pm 0,1$ & $\mathrm{PVP} /$ argila & $9,6 \pm 0,1$ \\
9 & $\mathrm{PVAl} /$ argila & $6,5 \pm 0,1$ & $\mathrm{PVP} /$ argila & $9,7 \pm 0,2$ \\
12 & $\mathrm{PVAl} /$ argila & $6,3 \pm 0,2$ & $\mathrm{PVP} /$ argila & $10,2 \pm 0,1$ \\
24 & $\mathrm{PVAl} /$ argila & $7,1 \pm 0,1$ & $\mathrm{PVP} /$ argila & $10,4 \pm 0,1$ \\
48 & PVAl/argila & $6,7 \pm 0,2$ & $\mathrm{PVP} /$ argila & $10,6 \pm 0,1$ \\
\hline
\end{tabular}


TABELA 20 - Concentração de antimoniato $\mu \mathrm{g} \mathrm{mL}^{-1}$ liberado pelas membranas de hidrogéis PVAl/quitosana/argila e PVP/quitosana/argila. Pela técnica de Espectrometria de Absorção Atômica com Atomização por Forno de Grafita (GFAAS).

\begin{tabular}{lllll}
\hline Horas & Membranas & $\begin{array}{l}\text { Concentração } \\
\left(\mu \mathrm{mL}^{-1}\right)\end{array}$ & Membranas & $\begin{array}{l}\text { Concentração } \\
\left(\mu \mathrm{mL}^{-1}\right)\end{array}$ \\
\hline 3 & $\mathrm{PVAl} /$ quitosana/argila & $3,0 \pm 0,1$ & $\mathrm{PVP} /$ quitosana/argila & $2,2 \pm 0,1$ \\
5 & $\mathrm{PVAl} /$ quitosana/argila & $2,8 \pm 0,1$ & $\mathrm{PVP} /$ quitosana/argila & $2,6 \pm 0,1$ \\
7 & $\mathrm{PVAl} /$ quitosana/argila & $2,9 \pm 0,1$ & $\mathrm{PVP} /$ quitosana/argila & $3,0 \pm 0,1$ \\
9 & $\mathrm{PVAl} /$ quitosana/argila & $3,3 \pm 0,1$ & $\mathrm{PVP} /$ quitosana/argila & $2,9 \pm 0,2$ \\
12 & $\mathrm{PVAl} /$ quitosana/argila & $3,6 \pm 0,2$ & $\mathrm{PVP} /$ quitosana/argila & $3,0 \pm 0,1$ \\
24 & $\mathrm{PVAl} /$ quitosana/argila & $3.9 \pm 0,1$ & $\mathrm{PVP} /$ quitosana/argila & $3,6 \pm 0,1$ \\
48 & $\mathrm{PVAl} /$ quitosana/argila & $4,2 \pm 0,2$ & $\mathrm{PVP} /$ quitosana/argila & $4,1 \pm 0,1$ \\
\hline
\end{tabular}

As concentrações de antimônio liberado pelas membranas de hidrogéis no modo estático estão representadas nas TAB. 21; 22 e 23.

TABELA 21 - Concentração de antimônio $\mu \mathrm{g} \mathrm{mL}^{-1}$ liberado pelas membranas de hidrogéis PVP/PVAl e PVP/PVAl/argila. Pela técnica de Espectrometria de Absorção Atômica com Atomização por Forno de Grafita (GF-AAS), modo estático.

\begin{tabular}{lllll}
\hline Horas & Membranas & $\begin{array}{l}\text { Concentração } \\
\left(\mu \mathrm{mL}^{-1}\right)\end{array}$ & Membranas & $\begin{array}{l}\text { Concentração } \\
\left(\mu \mathrm{g} \mathrm{mL} \mathrm{m}^{-1}\right)\end{array}$ \\
\hline 3 & PVP/PVAl & $0,5 \pm 0,1$ & PVP/PVAl/argila & $8,3 \pm 0,03$ \\
6 & PVP/PVAl & $7,5 \pm 0,01$ & PVP/PVAl/argila & $9,0 \pm 0,04$ \\
9 & PVP /PVAl & $8,2 \pm 0,03$ & PVP/PVAl/argila & $10,3 \pm 0,08$ \\
12 & PVP/PVAl & $8,2 \pm 0,01$ & PVP/PVAl/argila & $10,5 \pm 0,01$ \\
24 & PVP/PVAl & $8,5 \pm 0,02$ & PVP/PVAl/argila & $11,6 \pm 0,09$ \\
36 & PVP/PVAl & $7,5 \pm 0,02$ & PVP/PVAl/argila & $11,4 \pm 0,01$ \\
48 & PVP/PVAl & $8,3 \pm 0,01$ & PVP/PVAl/argila & $11,5 \pm 0,01$ \\
\hline
\end{tabular}


TABELA 22 - Concentração de antimônio $\mu \mathrm{g} \mathrm{mL}^{-1}$ liberado pelas membranas de hidrogéis PVAl/argila e PVP/argila. Pela técnica de Espectrometria de Absorção Atômica com Atomização por Forno de Grafita (GF-AAS).

\begin{tabular}{ccccc}
\hline Horas & Membranas & $\begin{array}{c}\text { Concentração } \\
\left(\mu \mathrm{mL}^{-1}\right)\end{array}$ & Membranas & $\begin{array}{c}\text { Concentração } \\
\left(\mu \mathrm{mL}^{-1}\right)\end{array}$ \\
\hline 3 & $\mathrm{PVAl} /$ argila & $0,5 \pm 0,1$ & $\mathrm{PVP} /$ argila & $12,9 \pm 0,1$ \\
6 & $\mathrm{PVAl} /$ argila & $0,52 \pm 0,1$ & $\mathrm{PVP} /$ argila & $9,4 \pm 0,01$ \\
9 & $\mathrm{PVAl} /$ argila & $5,5 \pm 0,1$ & $\mathrm{PVP} /$ argila & $9,8 \pm 0,03$ \\
12 & $\mathrm{PVAl} /$ argila & $6,4 \pm 0,1$ & $\mathrm{PVP} /$ argila & $10,1 \pm 0,04$ \\
24 & $\mathrm{PVAl} /$ argila & $6,7 \pm 0,2$ & $\mathrm{PVP} /$ argila & $10,5 \pm 0,04$ \\
36 & $\mathrm{PVAl} /$ argila & $7,5 \pm 0,1$ & $\mathrm{PVP} /$ argila & $10,8 \pm 0,01$ \\
48 & $\mathrm{PVAl} /$ argila & $7,6 \pm 0,1$ & $\mathrm{PVP} /$ argila & $10,8 \pm 0,03$ \\
\hline
\end{tabular}

TABELA 23 - Concentração de antimônio $\mu \mathrm{g} \mathrm{mL}^{-1}$ liberado pelas membranas de hidrogéis PVAl/argila e PVP/argila. Espectrometria técnica de Absorção Atômica com Atomização por Forno de Grafita (GF-AAS), para PVAl/quitosana/argila e $\mathrm{PVP} /$ quitosana/argila.

\begin{tabular}{|c|c|c|c|c|}
\hline Horas & Membranas & $\begin{array}{l}\text { Concentração } \\
\left(\mu \mathrm{gL}^{-1}\right)\end{array}$ & Membranas & $\begin{array}{l}\text { Concentração } \\
\left(\mu \mathrm{gL}^{-1}\right)\end{array}$ \\
\hline 3 & $\begin{array}{l}\text { PVAl /quitosana } \\
\text { / argila }\end{array}$ & $8,04 \pm 0,04$ & $\begin{array}{l}\text { PVP/quitosana / } \\
\text { argila }\end{array}$ & $5,8 \pm 0,03$ \\
\hline 6 & $\begin{array}{l}\text { PVAl/quitosana / } \\
\text { argila }\end{array}$ & $0,9 \pm 0,1$ & $\begin{array}{l}\text { PVP/quitosana / } \\
\text { argila }\end{array}$ & $0,79 \pm 0,1$ \\
\hline 9 & $\begin{array}{l}\text { PVAl/quitosana / } \\
\text { argila }\end{array}$ & $1,4 \pm 0,1$ & $\begin{array}{l}\text { PVP/quitosana / } \\
\text { argila }\end{array}$ & $1,0 \pm 0,1$ \\
\hline 12 & $\begin{array}{l}\text { PVAl/quitosana/ } \\
\text { argila }\end{array}$ & $1,9 \pm 0,1$ & $\begin{array}{l}\text { PVP/quitosana / } \\
\text { argila }\end{array}$ & $1,3 \pm 0,1$ \\
\hline 24 & $\begin{array}{l}\text { PVAI/ quitosana / } \\
\text { argila }\end{array}$ & $2,4 \pm 0,1$ & $\begin{array}{l}\text { PVP/quitosana / } \\
\text { argila }\end{array}$ & $1,6 \pm 0,2$ \\
\hline 36 & $\begin{array}{l}\text { PVAl/quitosana/ } \\
\text { argila }\end{array}$ & $2,9 \pm 0,1$ & $\begin{array}{l}\text { PVP/quitosana / } \\
\text { argila }\end{array}$ & $1,9 \pm 0,1$ \\
\hline 48 & $\begin{array}{l}\text { PVAl/quitosana/ } \\
\text { argila }\end{array}$ & $2,9 \pm 0,04$ & $\begin{array}{l}\text { PVP/quitosana / } \\
\text { argila }\end{array}$ & $2,5 \pm 0,1$ \\
\hline
\end{tabular}


As curvas da quitosana, PVP e PVAl puros analisadas pela técnica Difração de Raio-X (DRX), estão apresentadas nas FIG. 96, 97 e 98 respectivamente.

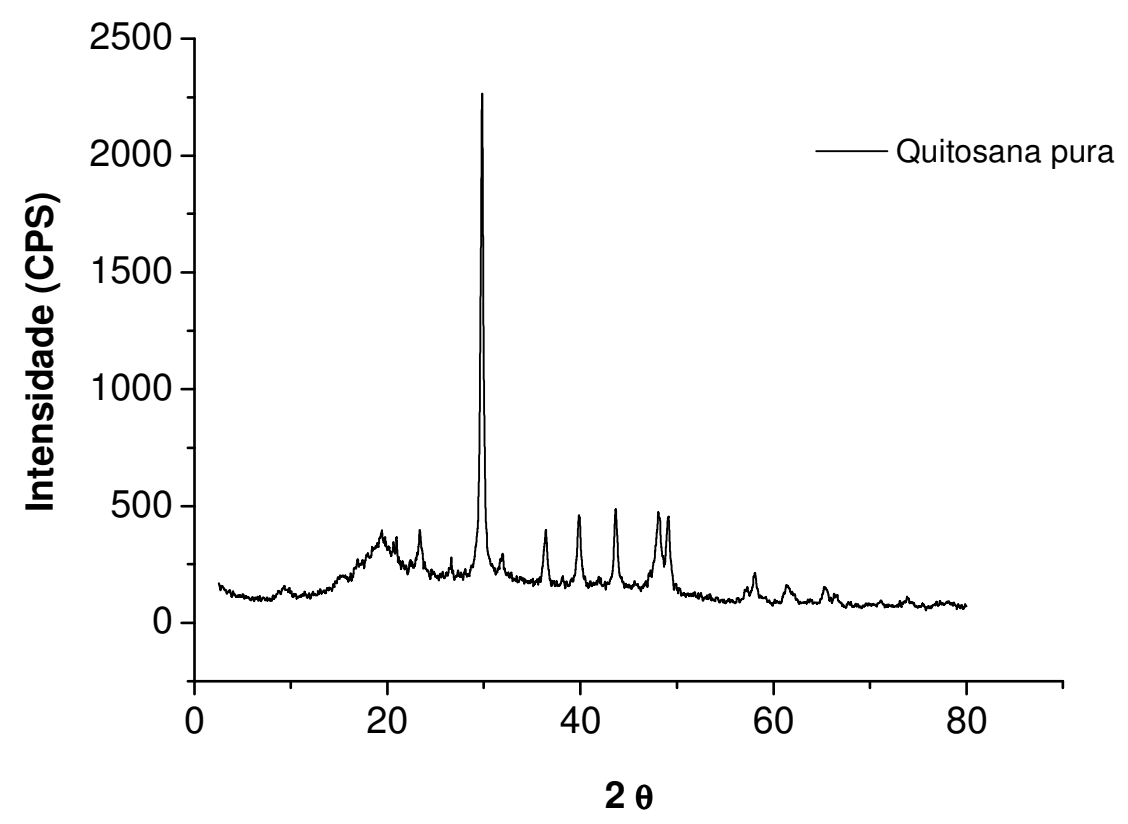

Figura 96 - Curva da quitosana pura.

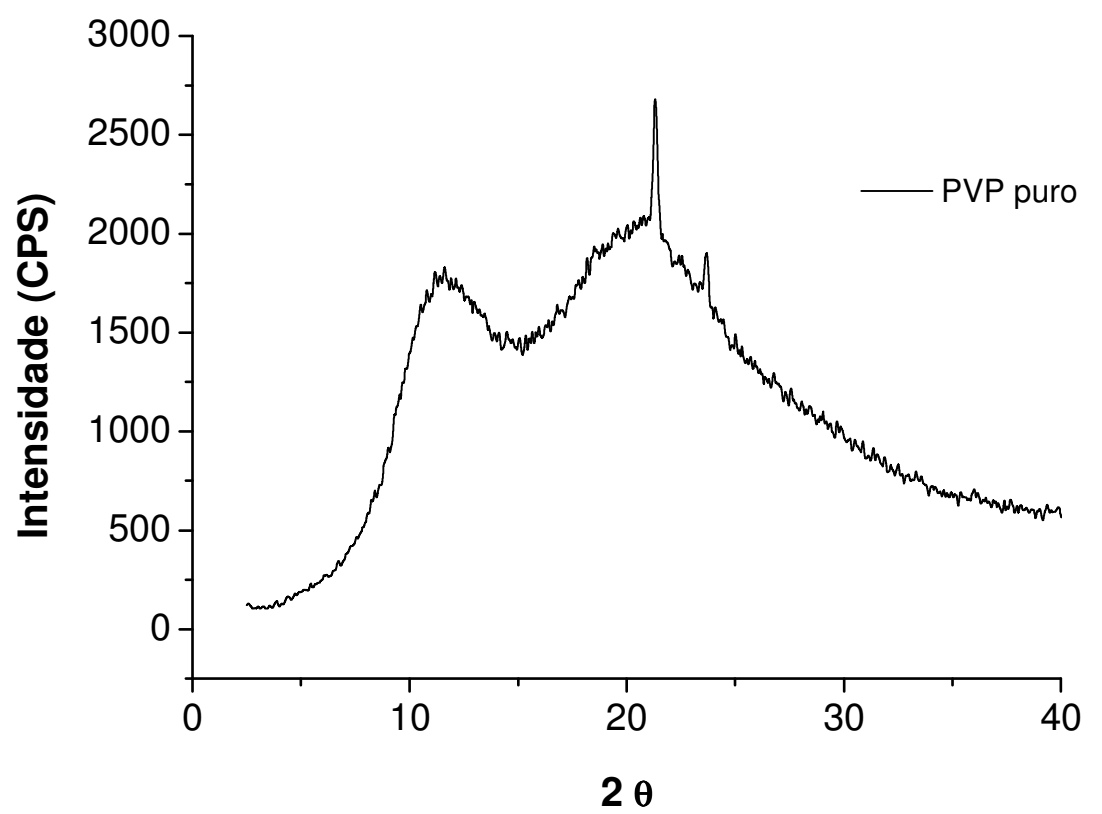

Figura 97 - Curva do PVP puro. 


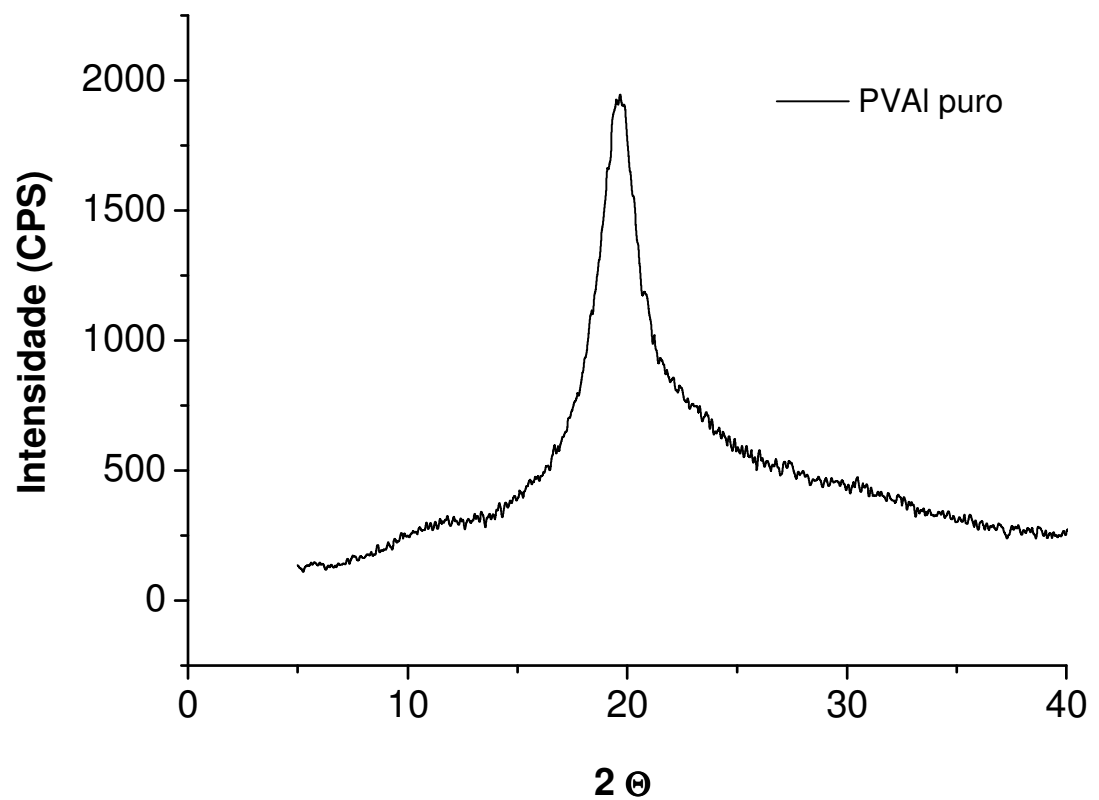

Figura 98 - Curva do filme de PVAl puro. 